\title{
REVISION AS RESISTANCE IN TWENTIETH-CENTURY AMERICAN DRAMA
}

\author{
Meredith M. Malburne-Wade
}

A dissertation submitted to the faculty at the University of North Carolina at Chapel Hill in partial fulfillment of the requirements for the degree of Doctor of Philosophy in the Department of English \& Comparative Literature in the College of Arts \& Sciences.

Chapel Hill

2013

Approved by:

María DeGuzmán

Linda Wagner-Martin

Minrose Gwin

Rebecka Rutledge Fisher

Heidi Kim 
(C) 2013

Meredith M. Malburne-Wade

ALL RIGHTS RESERVED 


\begin{abstract}
Meredith M. Malburne-Wade: Revision as Resistance in Twentieth-Century American Drama (Under the direction of María DeGuzmán)

Literary critics have long grappled with how to name, and how to process, texts that rely on earlier historical or literary moments as sources of inspiration and critique. Calling this process "revision" - the literal "seeing again" of that which has come before, my project seeks to demonstrate how American dramas consciously rewrite the past as a means of determined criticism and intentional resistance. While modern criticism often sees the act of revision or “borrowing" as derivative, this work uses Victor Turner's concept of the social drama (breach, crisis, redressive means, and resolution), and the concept of the liminal—put forth by Victor Turner, Arnold van Gennep, and Homi Bhabha - to argue for a more complicated view of revision. Examining works by Arthur Miller, William Carlos Williams, James Baldwin, Herman Melville, Richard Wright, Robert Lowell, and Lorraine Hansberry, this project demonstrates the ways in which American playwrights engage the past to create a theoretical space for challenging racism, colonialism, abuses of power, and other destructive forces. I argue that the rewriting of the past over the present generates the liminal, a threshold, through which we can purposefully examine assumptions, prejudices, and historical precedents. It is via this liminal moment that these playwrights hope to begin to construct an original future, one that releases us from the overarching control of the past.
\end{abstract}


To my teachers and professors who have said, "Yes, you can," through words and deeds.

To my husband, whose belief in me often far exceeded my own.

To my family and friends, who have supported me without reservation.

And to my students, who make it all worthwhile. 


\section{ACKNOWLEDGEMENTS}

I could not have completed this project without the help of my director, Dr. María DeGuzmán, whose unwavering support of my project (and me) was, simply put, life changing. Likewise, I must recognize the consistent encouragement of Dr. Linda Wagner-Martin, who has been an advocate for me since we first met many years ago. I also wish to deeply thank my current committee members, including Dr. Minrose Gwin, Dr. Rebecka Rutledge Fisher, and Dr. Heidi Kim, who have actively supported my work through the years, as well as my past committee members, Dr. Trudier Harris and Dr. Ashley Lucas, whose influences on my project persist.

I must also thank Ashley Reed, whose friendship and professional support have made this process both easier and worthwhile. Likewise, I wish to thank Dr. Jennifer Larson for sharing her work, her encouragement, and her friendship with me. There are many others I need to acknowledge, whose contributions have made their mark on my development as a scholar and a teacher, including Dr. Jane Danielewicz, Dr. Jenn Williamson, Dr. Megan Goodwin, Dr. Marc Cohen, Dr. Emily Brewer, Dr. Erin Branch, and Ms. Joy Cranshaw at UNC-Chapel Hill. Additionally, I wish to recognize the support of my mentors at Georgetown University and Wellesley College, including Dr. Maureen Corrigan, Dr. Mark McMorris, Dr. James Slevin, Dr. Patricia O’Connor, Ms. Sonia Jacobson, Ms. Sandra Hussey, Dr. Margaret Cezair-Thompson and Dr. Venita Datta. 
I am grateful for the support and assistance of the library staff at UNC-Chapel Hill and Elon University. Additionally, I would especially like to thank Beth Evitts, the Executive Director of the library at the Gettysburg campus of Harrisburg Area Community College, who helped me procure resources while I served as an adjunct there. I would also like to acknowledge the staff at the Schomburg Center for Research in Black Culture for assisting me with my week-long archival research on Lorraine Hansberry.

Finally, there are many family members and friends who have supported this endeavor. I wish to thank my husband, parents, grandparents, in-laws, and close friends for their help, encouragement, and faith through the years. 


\section{TABLE OF CONTENTS}

Introduction

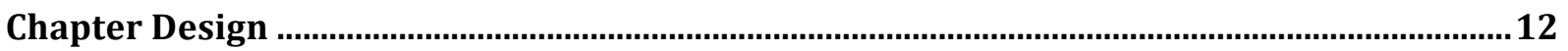

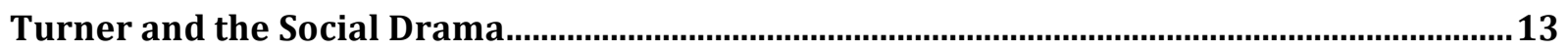

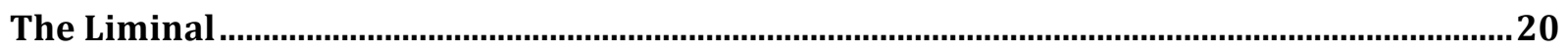

CHAPTER 1: CONFESSION AND CRIME, CONFESSION AS CRIME: WILLIAMS' TITUBA'S

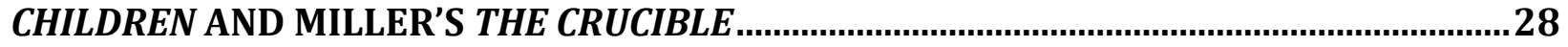

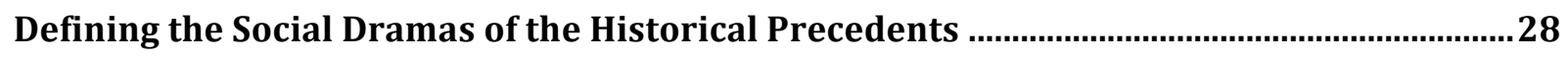

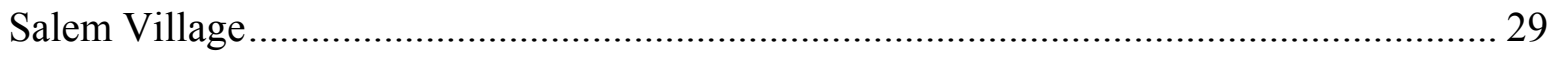

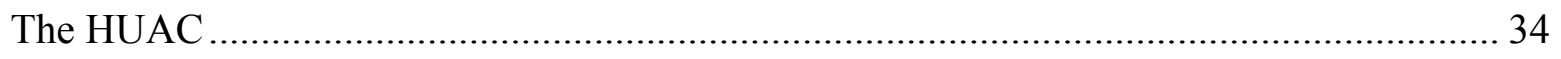

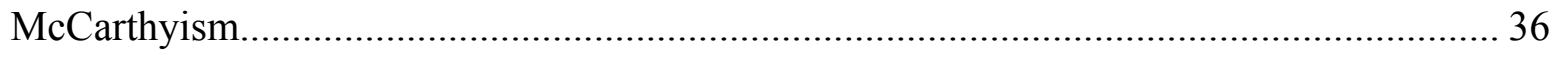

The Relationship Between Past and Present ............................................................ 37

The Act of Confession, the Definition of Crime.......................................................... 40

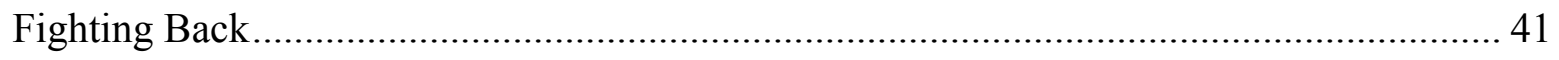

Tituba's Children: The Breach and the Liminal.............................................................................. 42

Play Summary and Production History ................................................................ 42

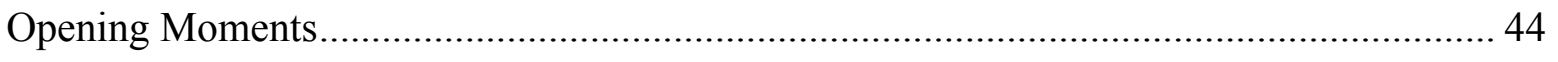

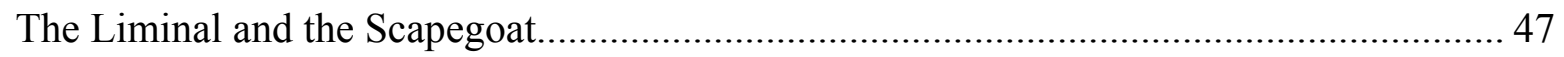

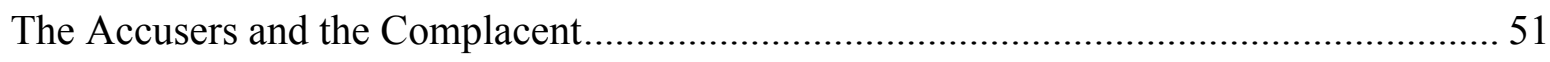

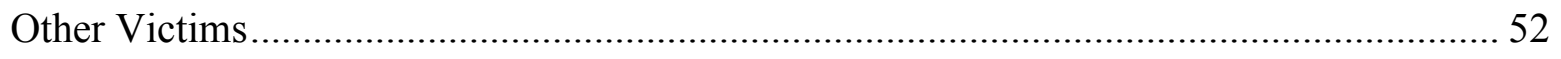

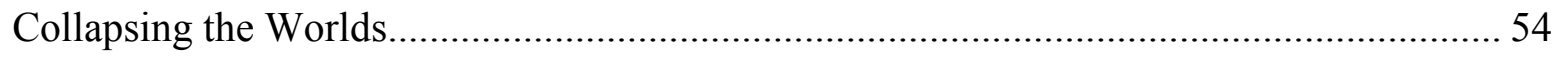




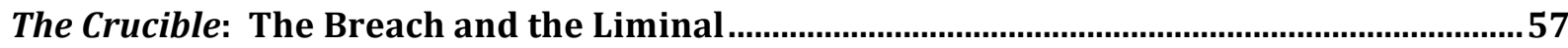

Play Summary and Production History.................................................................. 57

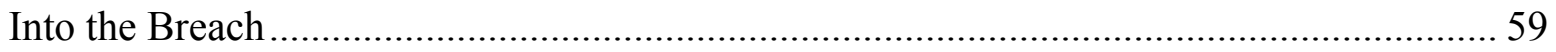

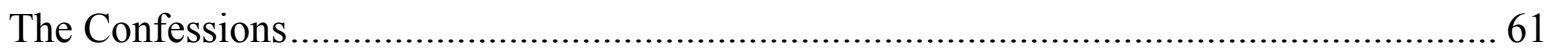

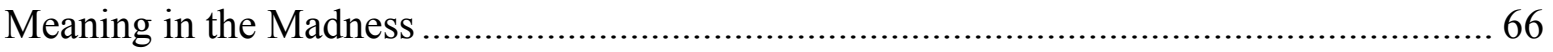

CHAPTER 2: CONFRONTATION AND CHALLENGE: BALDWIN'S BLUES FOR MISTER

CHARLIE AS RESPONSE TO THE MURDER OF EMMETT TILL.............................................69

Defining the Social Drama of the Historical Precedent …............................................................. 70

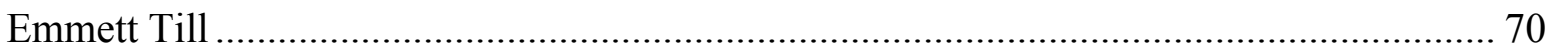

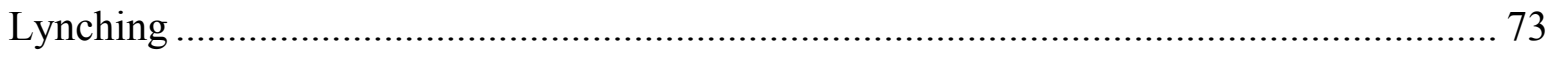

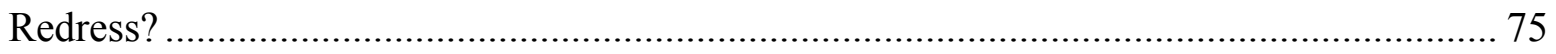

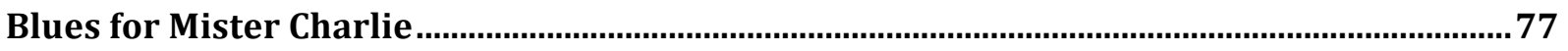

Play Summary and Production History ................................................................ 77

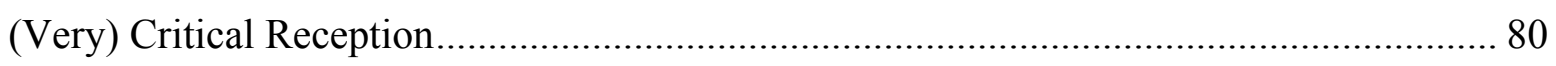

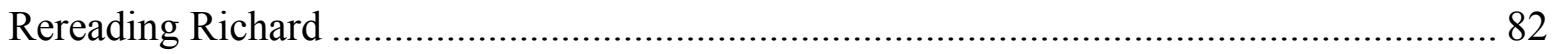

The Breach Becomes the Liminal ............................................................................ 85

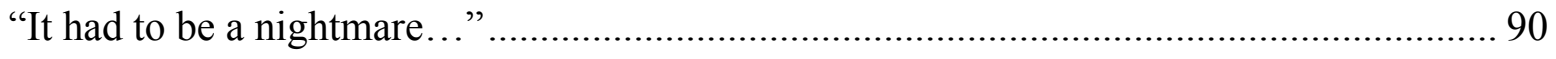

Richard Henry/Emmett Till as Abject .................................................................. 93

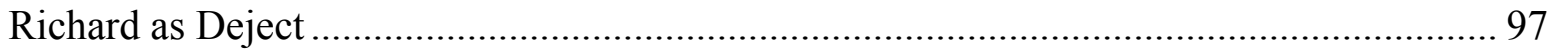

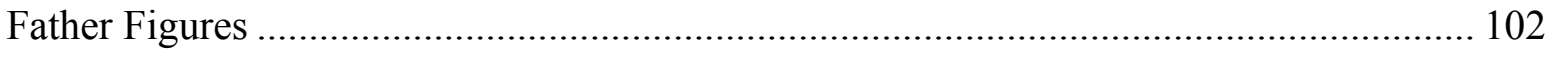

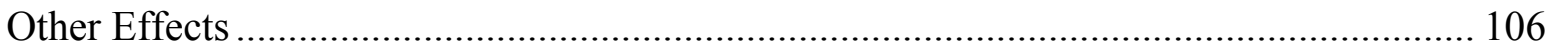


CHAPTER 3: CONDEMNATION AS REDRESS: HERMAN MELVILLE'S BENITO CERENO, RICHARD WRIGHT'S MAN, GOD AIN'T LIKE THAT..., AND ROBERT LOWELL'S BENITO

Defining the Past, Understanding the Present I: Amasa Delano and Herman Melville ..... 112

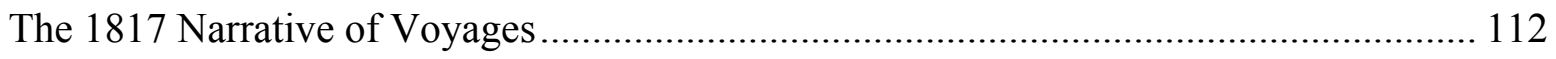

From Delano's Narrative to Melville's Benito Cereno................................................. 119

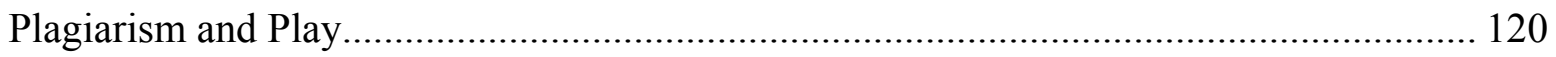

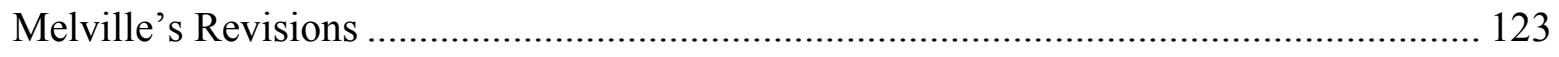

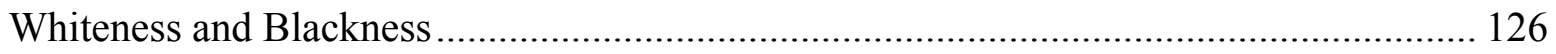

Binaries and Borderlands ............................................................................... 130

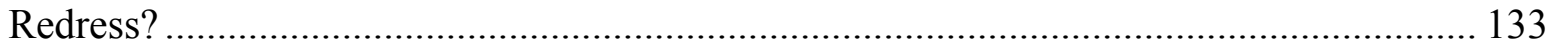

Defining the Past, Understanding the Present II: Herman Melville and Richard Wright.. 135

Play Summary, Production History, and Critical Reception ..................................... 135

The Animalistic and the Primitive ....................................................................... 137

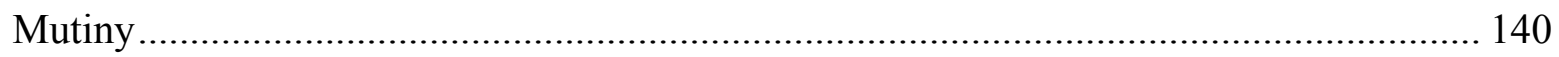

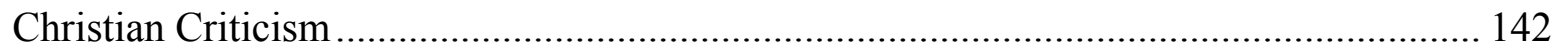

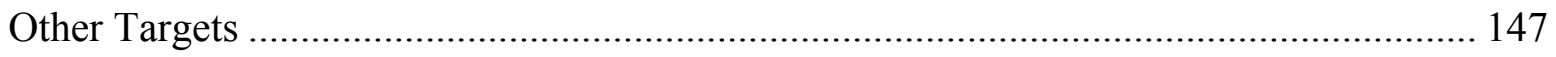

Defining the Past, Understanding the Present III: Herman Melville and Robert Lowell... 154

Play Summary, Production History, and Critical Reception ...................................... 154

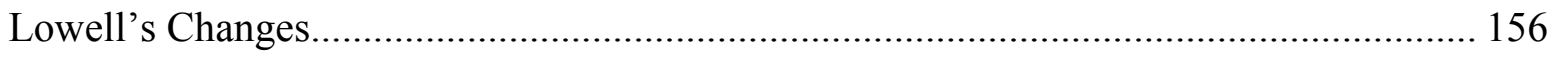

Delano and Wright: Unacknowledged Inspirations ............................................ 158

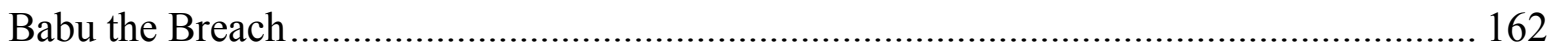

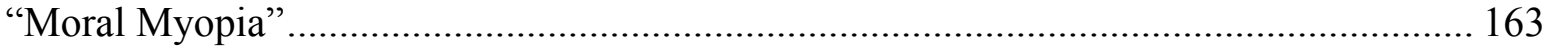




\section{CHAPTER 4: CELEBRATION OF FAMILY AS A MEANS OF DIFFERENCE AND HOPE: HANSBERRY'S A RAISIN IN THE SUN AND ODETS' AWAKE AND SING!.}

Defining the Social Dramas of the Literary and Historical Precedents ................................. 169

Play Summary and Production History: Awake and Sing!.......................................... 169

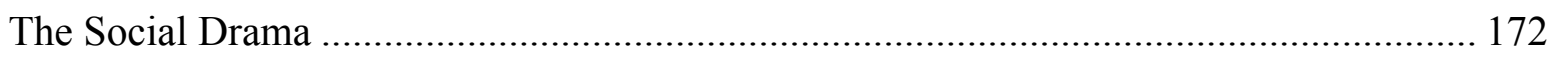

Play Summary and Production History: A Raisin in the Sun ..................................... 173

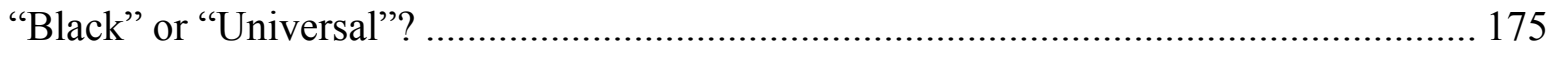

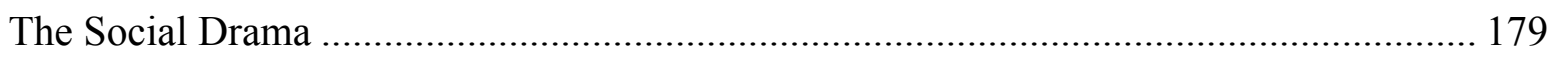

African American and Jewish Relations ................................................................. 181

Acknowledging and Exploring the Liminal: The Relationship between Awake and Sing! and

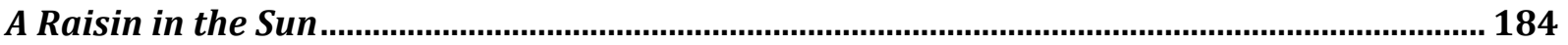

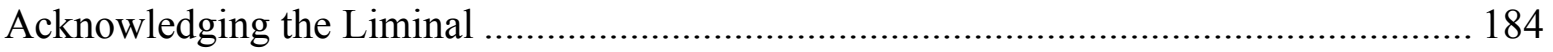

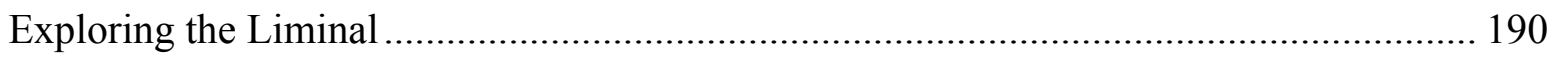

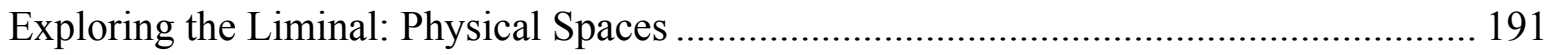

Exploring the Liminal: Mother-Matriarchs ............................................................... 192

Exploring the Liminal: Problematic Male Figures ..................................................... 197

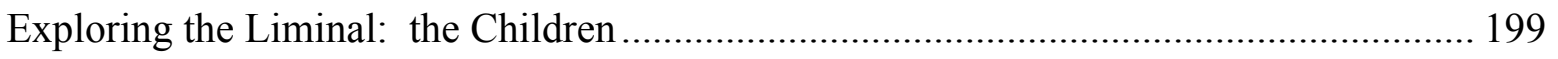

Exploring the Liminal: the Suitors and the Foreigners ........................................... 203

Exploring the Liminal: Questionable Endings................................................... 205

Exploring the liminal: the Capitalists …............................................................ 207

CONCLUSION: INTENTIONS AND IMPACTS ............................................................. 211

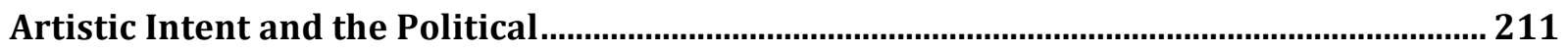

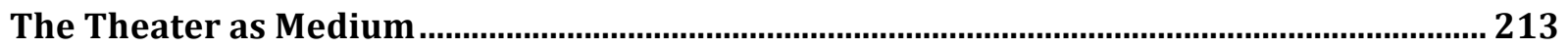

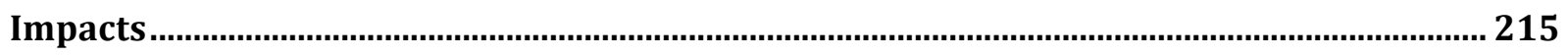


Agitation and Nationalism

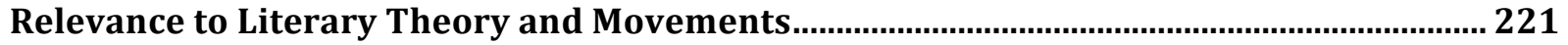

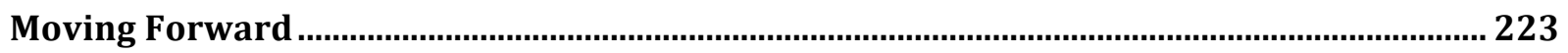

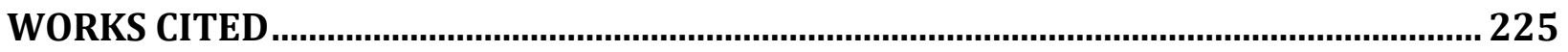


Only strong personalities can endure history; the weak are extinguished by it.

(Nietzsche 32)

\section{Introduction}

Many know the story of Emmett Till, the 14-year old Chicago boy brutally tortured and murdered while visiting his family in Mississippi. Till allegedly spoke to-or whistled at - the wife of a white store owner. Her husband and his half-brother dragged Till out of his family's home a few nights later, beat him, shot him, and dropped him in the river with a cotton gin fan tied around his neck with barbed wire. His mother insisted upon an open coffin and the subsequent photographs - published in magazines such as Jet and The Chicago Defender - helped to spark the Civil Rights Movement. The killers went free after a "fair trial," and subsequently admitted to the murder, protected by double jeopardy.

The story of Richard Henry, a character invented by James Baldwin in his play Blues for Mister Charlie and based on Emmett Till, is less well known. Henry is older, tougher, and full of anger and bitterness. The play itself opens in symbolic darkness and the first sound is that of a gun firing. The lights come up on a dead black body and a white murderer who "bends slowly and picks up Richard's body as though it were a sack. He carries him upstage and drops him" (Baldwin, Blues 2). The stage is built so that when Richard falls, he "falls out of sight of the audience, like a stone, into the pit" built off stage (Baldwin, Blues 2). The opening line of the play—spoken by the murderer-leaves the reasons for the killing quite clear: "And may every nigger like this nigger end like this nigger-face down in the weeds!" (Baldwin, Blues 2). 
The play quickly goes back in time to reveal the story behind the murder, but the audience knows what to expect because they have already seen the ending. The murder is inevitable because it has already happened, both in the opening moment of the play and in the historical precedent; one does not need to know that Richard Henry is based on Emmett Till to know the murder is coming. Besides an introduction to the published version of the play, Baldwin makes no overt mention of Till in the play or in the 1964 playbill for the original four-month run of the play at the ANTA Playhouse. Instead, the original audience received only two lines to guide them in the playbill: "The action of the play takes place in a small Southern town. The time is both in the present and in the past" (ANTA 24).

Nevertheless, Henry is unmistakably bound to Till. Like Till, he comes to the South after spending time in the North. Like Till, he insults the white store owner's wife. Like Till, he pays for his "crime" by death and is dropped into darkness. Like Till, Henry inspires those left behind to protest and potentially to fight. And yet, Henry is not Till. He is older. He was born and raised in the South, absent only for a few years. He does more than whistle at the shop owner's wife: he makes blatant—albeit sarcastic—sexual advances at her while insulting both the sexual and economic power of her husband. He reasons for his life when facing his murderer. He understands his actions and he performs them anyway—perhaps, no doubt, because the ending of this play was already written before Baldwin began. If Henry is to resemble Till at all, Baldwin can make only so many changes, and he certainly cannot alter the ultimate ending. Henry's fate is written in the bullet that opens the first scene; his fate is written in the racism that brings his fictitious/non-fictitious character into being. But what, then, is Blues for Mister Charlie? What are all the plays studied herein — plays that weave together the past and present in the hopes of influencing the future? What do we call and 
how do we make sense of plays, like Blues, that rely on their historical or literary precursors as a means of rewriting what has come before and what is still to come?

These are not new questions, as evidenced by the language that surrounds these types of works, which is as numerous as it is varied: intertextuality, adaptation, appropriation, mimesis, influence, translation, plagiarism, prequel, sequel, translation, postmodernist discourse, signifying, revision, revitalization, revamping, recounting, revisiting. The terms we have created to theorize, accept, or reject this relationship between texts are both numerous and still growing. ${ }^{1}$

Regardless of the terminology used to express textual relationships, the connection between texts has been, and continues to be, the focal point of significant scholarship. ${ }^{2}$ While

1 This list is by no means exclusive. In Julie Sanders text Adaptation and Appropriation, she recounts researcher Adrian Poole's long list of terms that have been used from the Victorian period forward to describe what is currently fashionable to term intertextuality: "borrowing, stealing, appropriating, inheriting, assimilating...being influenced, inspired, dependent, indebted, haunted, possessed...homage, mimicry, travesty, echo, allusion, and intertextuality" (qtd. in Sanders 3). She then adds her own terms to the list: "variation, version, interpretation, imitation, proximation, supplement, increment, improvisation, prequel, sequel, continuation, addition, paratext, hypertext, palimpsest, graft, rewriting, reworking, refashioning, re-vision, re-evaluation" (Sanders 3). Even given the large number of terms covered here, we do not begin to scratch the surface of the terms available for the phenomenon at hand.

${ }^{2}$ The amount of scholarship produced centered on the terms "mimesis," "intertextuality," and "revision" alone would quickly become overwhelming to recount. Indeed, Amazon.com displays over 300 mass produced texts currently available for purchase from the retailer that deal with mimesis and intertextuality alone. As clearly demonstrated from the prolific writings on the topic(s), the interest in the connections between texts and between authors is ongoing and growing - infiltrating theories of literature, music, scripture, visual art, and even television. Moving beyond the traditional realms of scholarship, intertextuality and the mimetic have infiltrated nearly every medium (For example, Movement and Mimesis: The Idea of Dance in the Sanskritic Tradition, by Mandakranta Bose, was published in 2007; Watching With The Simpsons: Television, Parody, and Intertextuality, by Jonathan Gray, was published in 2005). An Italian cosmetics company, Nouba, has even named a line of eye shadows "Mimesis," most likely in an attempt to take advantage of the ongoing fascination with the term and its meanings. 
terms such as pastiche, satire, and parody have long been consistent staples of literary theory, new terms (and re-used terms) have breached the horizon, meant to express something not quite yet represented, and potentially not yet understood. Theorists have begun, for example, to (re)turn to the term "translation" as the new form of mimesis or intertextuality. Fiona J. Doloughan's 2011 publication of Contemporary Narrative: Textual Production,

Multimodality and Multiliteracies uses the term to imply not only the traditional movement "from one language to another" but also the more contentious move from "one mode to another or from one medium to another"3 (5). Her work is seemingly influenced by Harold Bloom's quintessential The Anxiety of Influence (1973):

I mean to point to the notion that rather than creating or generating text in a vacuum, writers, consciously or otherwise, absorb and reply to other texts, thereby giving voice to what they have read, imagined and experienced in a new text that incorporates aspects of past production and evidences traces of the appropriation of the language of others. (Doloughan 5)

Such a statement certainly echoes Bloom's use of "creative misreadings," albeit with the addition of the unconscious. And yet, even Bloom himself was not satisfied with his original treatise on influence, following it up in 2011 with The Anatomy of Influence, in which he continues to explore new works (in much the same way as he did in The Anxiety of Influence) while pondering:

\footnotetext{
${ }^{3}$ Doloughan's definition could certainly be applied to the plays studied herein that move from history to drama, from novella to drama, and even from drama to drama. Her work is both supported and complicated by other contemporary views of translations, including Andrew Riemer's 2010 "Translation, Imitation and Parody"; Riemer argues that modern translations are "by necessity closer to imitation than to translation in the strict, formal sense of the term" (38). For Riemer, publishing restrictions and cultural differences often lead to these "imitations" or "adaptations to a greater or lesser extent" (38). While Doloughan is moving into the realm of translation, more broadly defined, Riemer is moving out of translation, requiring a more stringent definition of the term. Both, however, are adapting the terms used to describe texts reliant on other texts, and both are seeking the best way to talk about the varying, complicated relationships between texts.
} 
What is my creation and what is merely heard? This anxiety is a matter of both personal and literary identity. What is the me and the not-me? Where do other voices end and my own begin? The sublime conveys imaginative power and weakness at once. It transports us beyond ourselves, provoking the uncanny recognition that one is never fully the author of one's work or one's self. (20)

The relationship between texts, and writers, is as complex as it is tumultuous.

These questions and assumptions, present in Bloom, Doloughan, and other critics focused on mimesis/translation/influence/intertextuality, blur the line between authors and texts. They assume a certain level of "bleed" between texts, and they leave room both for the intentional use (which can vary from ode to satire to error, or, using Gérard Genette's classifications, from "quoting" to "allusion" to "plagiarism") (original emphasis; 2) and the unintentional/subconscious/unconscious use of others' texts, attributable to any number of reasons, including the extremes of carelessness and tribute. The ongoing development of terms to cover these phenomena, however, indicates that we have not yet found a comfortable or comforting way to think about these texts. Indeed, the proliferation of ways to talk about these texts, I argue, is proof of our discomfort with texts that borrow, play, and alter.

Part of our discomfort with this repetitive process in literature stems from the questions we are left with as we grasp for increased precision to accurately and appropriately represent both textual and intertextual meaning. How do we categorize and theorize the relationship between texts? Is there an allowable level of repetition in literature? Does the author need to acknowledge the relationship between texts in order to avoid charges of plagiarism or undue influence? Does the revision of textual material reify or destroy the original? Is it possible to alter the past? And what, after all, should we call this relationship? Alternatively, some of our discomfort with the use of revision/mimesis/repetition stems from 
an ongoing fascination with the new, evidenced in T.S. Eliot's "Tradition and the Individual Talent": "We dwell with satisfaction upon the poet's difference from his predecessors, especially his immediate predecessors; we endeavour to find something that can be isolated in order to be enjoyed" (Eliot, "Tradition" 1092). And while Eliot stresses the need for the poet and poem to feel the weight of the past, he also introduces a distinct modernist desire to consistently create the new and differentiate from the past.

It is here, in this moment of (inter)textual bleed and discomfort, that I seek to locate six American dramas that themselves are revisions of earlier "texts," whether historical or literary. The bleed between these texts is absolutely intentional; it drives the action and characters in the plays. As my chosen term implies, this bleed (or what Homi Bhabha may call "suturing," which carries similar imagery) between texts is often messy and disturbing. For many of the playwrights, such an overlap is meant to be uncomfortable, if not painful, exposing the lacks, problems, breaks, and suffering in the original (as in the discussion of Baldwin's Blues that opens this introduction).

Focusing on Arthur Miller's The Crucible, William Carlos Williams' Tituba's Children, James Baldwin's Blues for Mister Charlie, Richard Wright's Man, God Ain't Like That..., Robert Lowell's Benito Cereno and Lorraine Hansberry's A Raisin in the Sun, this project examines the sustained, complex, painful, and influential use of revision as a means of socio-political resistance. The Crucible and Tituba's Children revise the Salem Witch Trials in light of the hearings held by the House Un-American Activities Committee as well as Senator Joseph McCarthy. Blues for Mister Charlie is, as noted, a retelling of the Emmett Till murder. Man, God and Benito Cereno revisit Herman Melville's novella Benito Cereno. And Raisin tells the story of the Younger family, using Clifford Odets's Berger family of 
Awake and Sing! as its foundation. These retellings, regardless of original "text," use the process of revision as a process of transition. They move between stage and text; between text and predecessor; between past, present and future; between history and literature; and between the modern and postmodern literary moment. Thus, I view these revisions/dramas as transitional texts and I will demonstrate how these texts use the process of revision as a moment of complicated literary and historical transition.

These texts do not share a common predecessor, or even a common genre of predecessor (history vs. novella vs. drama). They vary regarding their choice to directly reveal, partially reveal, or indirectly reveal their source material. They are, however, focused on questioning and challenging aspects of American culture, society, and history, and they share similar tones, purposes, and means of pursuit. I am interested in the "bleed" between past and present in these texts, and how they use that liminal seepage as a means of criticism. I am therefore less interested in locating these texts in pre-existing categories (mimesis/adaptation/influence/satire/parody/intertextuality/signifyin'/appropriation /translation/etc.) as, in reality, these texts could be seen to embody parts of each of these theories while fully embodying none of them. These labels carry with them preconceived notions concerning the method and meanings between the textual connections, and yet this subset of American dramas, I believe, is more interested in working between-meanings and outside the lines. As such, this project is focused on ways of understanding what these unique dramas do and how they do it.

Perhaps one of the most important and most difficult tasks these plays attempt is the use of revision as moments of defiance and resistance in an attempt to demand (or at least suggest) an altered future. All of these texts extensively call upon and criticize preceding 
historical or literary moments. Each of these revisions seeks to condemn the past, finding it in some way both inescapable and inadequate. ${ }^{4}$ These dramas use this intertextual relationship to generate a new text, one that is meant to surpass, if not supplant, the original. For indeed, once a viewer or reader discovers the connection between texts, it becomes impossible to view either text in the same light again. T.S. Eliot notes that such a move should not be foreign; those who understand literature and history "...will not find it preposterous that the past should be altered by the present as much as the present is directed by the past. And the poet who is aware of this will be aware of great difficulties and responsibilities" (Eliot, "Tradition" 1093). This desire to alter the present, past, and even the future is one of the elements that makes these texts "transitional."

But to make that move, the texts do indeed, as Eliot implies, navigate both "difficulties and responsibilities." Like all revisions, they rely heavily on their predecessors for basic ideas surrounding content; they are at once inspired by and limited by what comes

\footnotetext{
${ }^{4}$ I use the terms "inescapable and inadequate" here to cover myriad meanings and various sins. The playwrights discussed herein find the past inescapable in a generally historical sense as they imply that the past completely dictates the present, oftentimes more than any other factor, including personal choice. It is this sense of the inescapable present in Nietzsche's assertion that "You can explain the past only by what is most powerful in the present" (40). Baldwin also explores this view of history repeatedly in his personal writings and essays. He argues: "I think that the past is all that makes the present coherent, and further, that the past will remain horrible for exactly as long as we refuse to assess it honestly" (Baldwin, "Autobiographical Notes," 7). But I also mean inescapable in a more personal, referential fashion. These artists relive and revive the past in order to explore and explain contemporary phenomena. In this way, they seem haunted by a past that refuses to remain gone, and their focus reinvigorates the past, making it once again palpable and pushing it to the forefront. Yet this past is inevitably deeply and disturbingly flawed, and thus I use the term "inadequate." I mean this primarily in a moral sense for all the playwrights herein. Miller, Williams, Baldwin, Wright, Lowell, and Hansberry all find the past deplorable, morally bankrupt and fundamentally opposed to American ideals. The term can also be seen, in the cases of Wright and Hansberry, to indicate a potential artistic inadequacy in the original literary text as well.
} 
before. Those reliant on history—Arthur Miller, William Carlos Williams, and James Baldwin — can retell their stories, but they are ultimately penned in by historical parameters. John Procter and Emmett Till, for example, cannot survive their narratives, even when their narratives are altered, embellished, and re-imagined. Those reliant on literary predecessors have more freedom to alter events and characters, but they must retain enough of the original to allow the reader to make the necessary connections or else the text-as-revision is lost. After all, to revise - to see again — is not to completely ignore that which has come before. But these texts nonetheless offer a different present, one that challenges our notions of history-as-fact, and one that asks viewers and readers to consider what they think they know. Or, as Charles W. Upham wrote in his 1867 account Salem Witchcraft: "History is the Past, teaching Philosophy to the Present, for the Future" (3; vol. 1).

In discussing playwright Suzan-Lori Parks, who also uses revision as a form of resistance in contemporary literature and drama, Jennifer Larson notes that Parks' work "challenges the ways readers imagine and experience history and/or receive recorded accounts thereof. These texts make history more visceral and relevant by asking readers to see the past as more personal and urgent" (Larson 3). In doing so, these texts demand a different future. They do not always receive their demands, but they place the onus of that outcome on the viewers and readers nonetheless. Anthropologist Victor Turner credits drama's adept fluidity between the indicative and subjunctive moods for its ability to question culture and cultural authority. Their versions of reality are capable of "making worlds that never were on land or sea but that might be, could be, may be" and they use "all the tropes, metaphor, metonymy, synecdoche, etc., to endow these alternative worlds with magical, festive, or sacred power, suspending disbelief and remodeling the terms of belief"' 
(Turner, The Anthropology 27). These transitional texts exhibit the past and the possible, at times simultaneously.

Thus, these dramas embody a space Richard Schechner reserves for the actor: just as the actor is at once "'not himself" and yet 'not not himself," simultaneously portraying a character while nonetheless retaining a sense of personal identity, these plays are at once their own entities and their pasts (Schechner 4). They serve much like aptly placed mirrors, reflecting both backwards and forwards in time. ${ }^{5}$ Thus Arthur Miller's John Proctor is at once the man, the historical memory, the contemporary retelling who condemns the HUAC and McCarthyism, and the hope for a future in which the need for such a character- or his story—ends. The Crucible thereby becomes literary moment, historical retelling, and social criticism. Betwixt and between, these plays bend boundaries as they defy standardized categorizations. Regardless, these texts stand on the threshold of past, present, and future, at once calling for, representing, and potentially aiding a transition between a failed yesterday and a potential tomorrow.

These dramas, all written within an important fourteen-year span in American history (1950-1964), share an intense belief in the transition to a more equal, a more just, indeed a more American, America. They desire to alter our understanding of the past in an attempt to generate space — a liminal space — for an improved future. They are informed, significantly, by their unique era in American history, surrounded by uncertainty, tense race relations, inequality, McCarthyism, and fear, but they all choose to plant their feet firmly in between a

\footnotetext{
${ }^{5}$ Turner calls dramas a "hall of mirrors - magic mirrors," as he sees them "interpreting as well as reflecting the images beamed to it, and flashed from one to the others. The manyleveled or tiered structure of a major ritual or drama, each level having many sectors, makes of these genres flexible and nuanced instruments capable of carrying and communicating many messages at once, even of subverting on one level what it appears to be 'saying' on another" (Turner, The Anthropology 24).
} 
divisive past and a-hopefully--decisive future. Their moment in history and their methods and agendas also place these dramas between the modernist and postmodernist literary moment, and the five works discussed herein play with (and amidst) the features of both literary modernism and postmodernism. What these texts share, however-their raison d'être - unites them despite their differences, as the following chapters will demonstrate. Before proceeding, however, it is essential to clarify that while this project will use terms such as "original" and "revision," they are used without prejudice. Of course, "original" and "revision" are loaded terms that carry significant rhetorical weight. I use "original" here strictly for convenience to note that which was temporally first, but I reject any subsequent implications of preferential worth. Similarly, I use the term "revision" without any intention of lessening the worth — or originality_of the work. We are, in many ways, accustomed to assigning proprietary value to that which comes first; the revision automatically becomes derivative. Yet, as Homi K. Bhabha argues:

The borderline work of culture demands an encounter with 'newness' that is not part of the continuum of past and present. It creates a sense of the new as an insurgent act of cultural translation. Such art does not merely recall the past as social cause or aesthetic precedent; it renews the past, refiguring it as a contingent 'in-between' space, that innovates and interrupts the performance of the present. (10)

Thus the "new" is a breakthrough, in a literal sense of the word, cutting into, or perhaps through, time. The creation changes time in many ways as it changes how we view both the past and present. Indeed, "every literary imitation is a supplement which seeks to complete and supplant the original and which functions at times for later readers as the pre-text of the 'original'" (Worton and Still qtd. in Sanders 158). We can see neither the original efforts nor the new whole in the same way; the past and present merge, becoming interdependent. Once the original is viewed via the revision, we cannot undo what we have seen; our vision is 
altered. That altering of our vision of past and present (and, thus, potential futures) is inherent to what I see as the transitional worth of these texts.

Linda Hutcheon, in discussing parody — itself a form of revision—notes, "To some critics, parody makes the original lose in power, appear less commanding; to others the parody is the superior form because it does everything the original does - and more" ( $A$ Theory 76). Reversing the typical original/revision hierarchy, Hutcheon offers ways in which the revision exceeds the original. The authors discussed herein can most certainly be seen as attempting to drain the original's power in an effort to highlight and potentially rectify the underlying social problems intrinsic to it. Indeed, each of these plays attacks an earlier historical moment or literary text in an effort to suggest or effect social change. Yet this is clearly not all that they set out to do. Some of these texts have not been seen previously as revisions; they have stood on their own and have been successful (or unsuccessful) as independent literary and dramatic works. This struggle between original/revision will recur throughout this project, but it is important to note that my use of the terms is in no way indicative of an acknowledgement of superiority (in either direction). The remainder of this introduction will offer a more detailed overview of the theoretical underpinnings of the revisions/transitions while outlining the forthcoming chapters.

\section{Chapter Design}

Each of the following chapters focuses on a pair (or more) of texts which focus on a single original theme, whether historical or literary. The first section of each chapter will use Victor Turner's theory of social drama to ground the discussion of the play-as-socio-political moment. The second half of each chapter will examine the moments of intentional connection with and just-as-intentional divergence from historical and/or literary 
predecessors that define these plays. Much of this focus will be driven by concepts of the liminal, as discussed by Arnold van Gennep, Victor Turner, and Homi Bhabha.

Each chapter is also driven by a theme related to an act of resistance. Miller and Williams center their plays on acts of confession (and refusing to confess) as a means of highlighting the absurdity of the times (referring both to Salem and the HUAC/McCarthyism). Both historical moments featured often meritless accusations of witchcraft or Communism, and the act of confession and subsequent contrition was often the only way to avoid actual death or the death of one's career. Baldwin's play moves from confession to confrontation. Rather than simply highlighting the absurdity of the situation, Baldwin pushes his main character to the edge of reason in his defiance and demand for recognition. No act of confession will save Richard Henry, but Baldwin refuses nonetheless to make him a victim, instead empowering him with anger, desire, and humanity. As damning as Baldwin's play is, Wright and Lowell increase the level of criticism, moving from confrontation to condemnation. No one, it seems, escapes Wright's play unscathed as all characters are deeply flawed and are held up for ridicule; Lowell focuses primarily on the failings of white America. Finally, Hansberry begins the move away from such dominant negativity and towards what I will call celebration. Hansberry's play is by no means uncritical or unconcerned with highlighting the problems of her literary (and historical) predecessors, but her work outlines the failures of the past by creating a family with hope for the future.

\section{Turner and the Social Drama}

The texts of Miller, Williams, Baldwin, Wright, Lowell and Hansberry straddle dual mediums of reception. Like all plays, the dramas discussed herein are meant to be seen and 
to be heard (or, in the case of Wright's play—a radio play originally aired in Germany_simply heard). But each of these plays was clearly also meant to be read, a fact made evident by introductions that highlight the connections between past and present (Baldwin), expansive sections appearing only in the published versions (Miller and Williams), and by small, important details revealing the layering between past and present discernible only after multiple readings (Hansberry, Wright, and Lowell). Thus, even in terms of how best to understand these pieces, they remain transitional, requiring multiple forms of "seeing" in order to be fully appreciated.

Part of the reason these texts exist somewhere between traditional stage dramas and written texts meant to be read and reread has to do with their transitional status between literature and social statement. These plays are undeniably literature, as subsequent chapters will prove, but they also exist as a means of encouraging action. Perhaps it is unsurprising, then, that one of the guiding forces for (re)viewing these plays is not traditional literary theory but the theories of anthropologist Victor Turner. Katherine M. Ashley notes in her introduction to Victor Turner and the Construction of Cultural Criticism, it may not be such a strange — or at least not solitary—place to be: "In the current attempts to redefine literature as social 'artifact' or social 'discourse,' and to situate literary studies within cultural criticism, an indispensable role has been played by those who take society and culture as their primary subjects—-sociologists and anthropologists" (ix). Turner helps us to understand how these plays function in their (and against their) social circumstances.

Turner, in viewing plays as inseparable from their "use in social settings," acknowledges that plays should not be seen "merely as scripts," but instead, "Their full meaning emerges from their union of script with actors and audience at a given moment in a 
group's ongoing social process" (The Anthropology 24). But they are not simply social events; they "become a way of scrutinizing the quotidian world," both in Eastern and Western traditions (The Anthropology 27). The power, however, rests in the relationship between the play and its society:

the aesthetic drama of the age can be only partially understood and hence appreciated if the social, political, and economic factors are overlooked. What we are looking for here is not so much the traditional preoccupation with text alone but text in context, and not in a static structuralist context but in the living context of dialectic between aesthetic dramatic processes and sociocultural processes in a given place and time. (The Anthropology 28)

While New Historicism has taught us that all pieces of literature are arguably products of their time and place, these works by Williams, Miller, Baldwin, Wright, Lowell and Hansberry rely more heavily on their sociocultural context for depth and meaning than many works. As pieces bridging the tenses, both in terms of the relationship of the past to the present/future and the relationship between the indicative (what is) and the subjunctive (what could/should be), they rely on the knowledge and understanding of the audience in seeing the invisible thread that binds the pieces, or tenses, together. Thus, we can appreciate A Raisin in the Sun for its complex portrayal of an African American family in post World War Two Southside Chicago without seeing its connection to Clifford Odets' Awake and Sing!, but in missing the context, we also miss the subtext. We may see the poverty of the Younger family, but we miss the biting social commentary on the ongoing effects of the Great Depression on African Americans if we miss the bridge that is Awake and Sing! We may see the strained relationship between African Americans and Whites in the text, but we fail to see that the proverbial stage was set by Odets with his off-hand dismissal of African Americans in his own text. Surely, we do not need to see Odets to understand the historical 
tensions of the time, but seeing the texts together, present over past, offers a clearer and more nuanced view of the problems of race, religion, and economics in America. ${ }^{6}$

The layered understanding necessary for both New Historicism and understanding these works is visible in Turner's interpretation of drama itself. Defining the difference between "play" (and what will become drama for him), and "work," Turner notes:

\footnotetext{
${ }^{6} \mathrm{I}$ am, in many ways, reminded of Gloria Anzaldúa's concept of synthesis here, as seen in Borderlands/La Frontera: the New Mestiza. In discussing hybridity in the "new mestiza," Anzaldúa notes:
}

In attempting to work out a synthesis, the self has added a third element which is greater than the sum of its severed parts. The third element is a new consciousness - a mestiza consciousness - and though it is a source of intense pain, its energy comes from continual creative motion that keeps breaking down the unitary aspect of each new paradigm. (101-102)

Similarly, Williams, Miller, Baldwin, Wright, Lowell and Hansberry each generate a text that is more than itself and more than the past it recreates. A hybrid, it is seared by the historical weight - and often historical pain — of the past, but that weight is compounded by a present that fails to have changed considerably. More than the weight of these precedents, however, the new text seeks to make its own mark, to suggest that if we are cognizant of the pieces of the whole, we can begin to change its shape. In rewriting the past, we begin to erase the concept of unmovable history. While transitional or revisionist drama may not seem revolutionary or radical to some, it is an act of resistance nonetheless: to alter is to hope. To re-see is to envision that difference is possible. At times when thought and action appear homogenous and oppressive and include McCarthyism, segregation, prejudice, and murder, to suggest an alternative vision is an action, and action - or in this case counter-action-is essential:

The content matter, the presentation, the potential energizing disturbance for the audience - even the acting itself - make the theater the ideal locus for art that seeks change: It is not only a play conceived as a weapon of political struggle: it promotes the statement that 'acting' - the power to be knowingly protean in appearance, to use the expressive qualities associated with theatrical performance - can and should be a weapon of struggle. Or as [Athol] Fugard had written in his notebook a decade or so earlier: 'Revolt (meaning) can only come with consciousness...W Without consciousness we become victims instead of actors - even if it is still only a question of acting victims. And in this make-believe of our lives the audience is self.' (Crow and Banfield 107) 
work is held to be the realm of the rational adaptation of means to ends, of 'objectivity,' while 'play' is thought of as divorced from this essentially 'objective' realm, and, in so far as it is its inverse, it is 'subjective,' free from external constraints, where any and every combination of variable can be 'played' with. (Turner, From Ritual 34)

Of course, Turner's discussion of "variable[s]" suggests a control; he may have meant to use the terms to draw the comparison between objective work and subjective play, but his quote also highlights the malleable nature of history that the transitional texts of Williams, Miller, Baldwin, Wright, Lowell and Hansberry employ so well. That manipulation is intrinsic to theater itself as "such genres as theater," are, according to Turner, designed to "probe a community's weaknesses, call its leaders to account, desacralize its most cherished values and beliefs, portray its characteristic conflicts and suggest remedies for them, and generally take stock of its current situation in the known "world"” (Turner, From Ritual 11).

For Turner, theater is capable of such feats because its roots are entrenched in what he deems "social drama," or the four-stage cycle almost all significant disruptions of community stability follow, regardless of location, or "an objectively isolable sequence of social interactions of a conflictive, competitive or agonistic type" (Turner, From Anthropology 33). Social dramas are "initiated when the peaceful tenor or regular, norm-governed social life is interrupted by the breach of a rule controlling one of its salient relationships" (original emphasis; Turner, From Ritual 92). For Turner, such a breach must be "publicly visible" and must disrupt "a rule ordinarily held to be binding, and which is itself a symbol of the maintenance of some major relationship between persons, statuses, or subgroups held to be a key link" in the community itself (Turner, The Anthropology 34). The breach may be premeditated to challenge social norms or customs, or it may erupt without significant notice (Turner, From Ritual 70). Certainly, there is usually a series of events, insults, and minor 
disruptions that may lead to the final, decisive breach, but Turner is interested in starting with the breach itself, presumably because it is highly visible, more easily defined, and begins, for him, another series of events surrounding the eventual resolution (or dissolution) of the problem.

The breach is immediately followed by Turner's second stage, the crisis, and at times the two can quickly become inseparable. Inevitably, people must respond-usually rapidly— to the disruption in the social fabric:

Once visible, it can hardly be revoked. Whatever the case, a mounting crisis follows, a momentous juncture or turning point in the relations between components of a social field - at which seeming peace becomes overt conflict and covert antagonisms become visible. Sides are taken, factions are formed, and unless the conflict can be sealed off quickly within a limited area of social interaction, there is a tendency for the breach to widen and spread until it coincides with some dominant cleavage in the widest set of relevant social relations to which the parties in conflict belong. (Turner, From Ritual, 70)

Turner notes that this crisis, begun "when a major normative knot is cut," usually involves the threat of violence, even if violence itself is never present (Turner, The Anthropology 34).

Following the crisis, the community takes stock of the situation and attempts to apply "redressive or remedial procedures" (original emphasis; Turner, The Anthropology 34). Turner notes that the redressive means run a large gamut of activities, from "personal advice" to "mediation or arbitration...formal jural and legal machinery...to the performance of public ritual" (Turner, The Anthropology 34). This stage is "the most reflexive of the social drama" as the community grapples with the reasons for the breach and subsequent crisis, as well as how the actions and accusations measure up against the community's own expectations of unity (Turner, The Anthropology 34). Importantly, Turner places "all the genres of cultural performance," including theater, as occurring within the third stage, redressive means. As moments of reflection and challenge, theater and performance often serve to question, 
examine, and criticize the society from which they originate or on which they focus (original emphasis; Turner, From Ritual 108).

Ideally, social dramas are resolved in the final stage, resolution, either via the "reintegration of the disturbed social group, or the recognition and legitimation of irreparable schism between the contending parties" (original emphasis; Turner, The Anthropology 35). Turner notes that if "the social drama runs its full course, is satiated, so to speak, the final phase consists of actions restorative of peace, often of a practical sort" (original emphasis; Turner, The Anthropology 35). If redressive means have functioned appropriately, a return to normal_ or a new normal — is facilitated.

Social dramas, as part of actual day-to-day existence, however, are not always that simple or that clean, a point with which Turner has to contend. In cases where the breach is severe enough to call into question the legitimacy of the redressive means- whether those means include elders, rituals, legal systems, or other "machinery," crisis begins anew and is perpetuated (Turner, The Anthropology 35). Such a reversion may lead to stronger, more equal or fair redressive processes, or it may lead to revolutions or a "state of endemic, lowkey conflict between cliques of adversaries who oppose one another on almost every issue," preventing any chance of peace without further upheaval (Turner, The Anthropology 35).

Each of the six transitional plays here examined is based, in some way, on an originating social drama. For those plays responding to historical events, such moments are quite clear-from the Salem Witch Trials, to McCarthyism/the House Un-American Activities Committee, to the Emmett Till murder. But even for the remaining four plays, based primarily on earlier literary works, the social drama backdrop is still applicable as history and society are never far from these works, whether in the form of the African Slave 
Trade or ongoing overt acts of racism. And yet, each of these plays, like most dramas, is also a form of redress - a way of grappling with and speaking out against the very moments to which it responds. I argue that each of these dramas seeks both reaction — and hopefully action — from the audience. Thus, these plays teeter between redressive means, plays that seek to right the wrongs and find resolution, and instigators, plays attempting to force us back into the breach, or back into the crisis, in order to find better means of redress and resolution. For in each instance, it is clear that the other existing redressive means, including, indeed, even theater itself, remains insufficient to address the failures at hand.

\section{The Liminal}

In order to grasp how these plays function as redressive means and as embodiments of social drama, we must understand how these plays engage the past and their predecessors. The complicated relationship between these texts and their predecessors demands that, in order to grasp the full weight of the connections, the audience must become viewer, reader, and sleuth. These texts are once again transitional texts because they require submersion in text and stage, text and predecessor, in order to understand the depth of their connections and breadth of their criticisms.

How each transitional text reveals its clues varies widely. Two of the earliest stage dramas here (William Carlos Williams' Tituba's Children, written in 1950 and published in 1961; Arthur Miller's The Crucible, completed in 1952 and produced in 1953) use the Salem Witch Trials as a medium to discuss the social/political/artistic witch-hunt that was McCarthyism. Williams is the most transparent of the playwrights in this study, literally overlapping moments depicting the witch trials and the HUAC/McCarthy hearings on stage, using the same actors, and making explicit references to their connections. His use of single 
characters to play multiple roles within the distant past (Salem) and the more recent past/present (HUAC/McCarthyism), creates literal, visible portals between worlds where the past seeps forward into the present. Miller's play is clearly meant to evoke McCarthyism, but his drama remains firmly planted in Salem. His liner notes, which may or may not be reproduced with every production, clearly spell out his intentions. There is a weight of discovery placed on the reader/viewer of Miller's work that is not present in Williams'. Like Williams and Miller, James Baldwin calls upon a historical moment as his starting point in his 1964 production of Blues for Mister Charlie. The drama re-enacts the Emmett Till murder using an older, decidedly more autonomous and defiant Richard Henry in Till's place in order to demonstrate that regardless of the circumstances, Till's murder was inexcusable. Like Miller, Baldwin relies on an introduction to the text to clearly spell out the relationship between the "texts." And yet, that introduction would not be available to most theater-goers. Indeed, the original 1964 playbill for Blues does not include the revealing introduction by Baldwin. In 1957, Richard Wright wrote an acerbic German radio play, Man, God Ain't Like That..., which revised Herman Melville's 1855 novella Benito Cereno to demonstrate the negative effects of ongoing racism and misguided missionary Christianity. His "original" text, literary instead of historical, relies upon shared scenes and closely related names in order to indirectly alert the reader/listener to the connections. Robert Lowell's 1964 production, Benito Cereno, revises Melville's novella of the same name (and, I argue, also revises Melville's original historical text as well as Wright's radio play) in order to highlight the ongoing race struggle of the 1960s. In 1959, Lorraine Hansberry's A Raisin in the Sun revised Clifford Odets's 1935 play Awake and Sing!, replacing the materialistic, selfabsorbed, and simultaneously divided/divisive Berger family with the determined, adaptive, 
and ultimately united Younger family. Like Wright, Hansberry relies on details such as names and circumstances in order to demonstrate the connections between the works. Moving in this order, from Williams and Miller to Baldwin, Wright, Lowell, and Hansberry, we can see an increasing amount of pressure being placed on the viewer/reader to follow the clues back to an "original" text.

Indeed, the pressure to find the source material(s), however obvious or obfuscated, is inherent to the transitional texts studied here. We are challenged to know, and to own, our personal pasts, histories, and literatures. As Richard Wright states in 12 Million Black Voices while speaking of African Americans, "What we want, what we represent, what we endure is what America is. [....] If America has forgotten her past, then let her look in to the mirror of our consciousness and she will see the living past living in the present" (original emphasis; Wright 146). It is a voice echoed by Lorraine Hansberry in To Be Young, Gifted and Black as she discusses the African American writer: "He stands neither on a fringe nor utterly involved: the prime observer waiting poised for inclusion" (Hansberry 256). Black or white, however, these artists all position themselves in a space "neither on a fringe nor utterly involved," at once the "living past" and the "present"; they stand in the transitional moment, simultaneously awaiting and ushering in change. Painfully aware of the past, whether historical or literary, they push that past into the present, demanding that the purveyors of that past recognize it:

When historical visibility has faded, when the present tense of testimony loses its power to arrest, then the displacements of memory and the indirections of art offer us the image of our psychic survival. To live in the unhomely world, to find its ambivalencies and ambiguities enacted in the house of fiction, or its sundering and splitting performed in the work of art, is also to affirm a profound desire for social solidarity. (Bhabha 26-27) 
These plays reintroduce and re-imagine history via "sundering and splitting," forcing the viewer, if s/he accepts the challenge, to see the world differently. Playwrights such as Williams layer the present over the past in a way that forces the viewer to read one through the other; playwrights such as Hansberry challenge the viewers to know the past well enough to read the present. The more obfuscated the relationships between the texts, one could argue, the more subversive the texts become. The clues are there regardless, but our failure to recognize them, and to recognize our past—particularly an often dominant, usually white, and always American past—becomes yet another mark of our inadequacy.

When (or perhaps, sadly, if) the relationship between revision and original are discovered by the viewer (or more often by the reader), the consumer ${ }^{7}$ experiences something similar to pentimento ${ }^{8}$ in painting, where an old image or section of canvas seeps through

\footnotetext{
${ }^{7}$ I use this potentially controversial term intentionally to indicate the artists' desire for the consumption of the product (the play). These plays, given their use of revision and their incorporation of the past or past texts, are meant to be viewed and reviewed-literally ingested, and turned around in the mind of the viewers. I also intend to evoke the fact that these plays are meant to be seen (or in the case of Wright, heard) first and foremost; audiences are meant to pay for the performance, to pay for the privilege and the responsibility of reviewing and recalculating the weight of the past.

${ }^{8}$ I am invoking Lillian Hellman's use of the term pentimento here, from her autobiography of the same name. Using the term as a framing device for her narrative, she states:
}

Old paint on canvas, as it ages, sometimes becomes transparent. When that happens it is possible, in some pictures, to see the original lines: a tree will show through a woman's dress, a child makes way for a dog, a large boat is no longer on an open sea. That is called pentimento because the painter 'repented,' changed his mind. Perhaps it would be as well to say that the old conception, replaced by a later choice, is a way of seeing and then seeing again. (Hellman 1)

Like the viewer who can see the existence of both paintings on the same canvas, the reader/viewer who is aware of the dramatic revision must come to terms with both versions of the text - the original and the revision - layered one over the other. Moreover, while this term has been replaced in modern lexicon by terms such as "translation" and "palimpsest," 
into the new and both past and present are suddenly visible simultaneously. This moment of past and present combined, of inhabiting the space between both times, is what we will term a liminal moment, a literal threshold between past and present, ending and becoming.

The liminal can be defined as a threshold between times, worlds, moments or even pieces of literature. Arnold van Gennep's $1909^{9}$ study on rites of passage introduced the term to anthropological studies and it has been adapted frequently since. For van Gennep, the liminal harkens back to a time when tribes of people occupied lands separated by significant distance and by chosen markers of the inner and outer parameters. The boundaries established by a people were surrounded by "neutral zones...ordinarily deserts, marshes, and most frequently virgin forests where everyone has full rights to travel and hunt" (18). When one moves from the protected, approved land of one's tribe into the neutral zone, one "finds himself physically and magico-religiously in a special situation for a certain length of time: he wavers between two worlds" (van Gennep 18). Thus, there is a transitional space, endowed with magic, freedom, and symbolic nothingness that once existed physically via the claiming of tribal lands and now exists primarily in the moment of ritual. The physical boundary becomes the figurative threshold.

In ritual there is often still a metaphorical "neutral zone." For example, in many tribes, young men are separated from the tribe for a pre-determined length of time in order to be re-introduced and initiated into manhood. For van Gennep and later Victor Turner, that time outside the tribe, when the initiate is neither tribe member nor not tribe member, is a

there is an appropriateness in using this term which is contemporaneous with the works discussed here and which is replete with undertones of repentance and change.

${ }^{9}$ The original 1909 version, one of the first to so closely examine rites of passage, was published in French; the first English translation was published in 1960. 
liminal moment. Those in liminal states, removed from the structures, laws, society, and customs that both restrict and define them, are "necessarily ambiguous" and "betwixt and between the positions assigned and arrayed by law, custom, convention..." (Turner, The Ritual Process 95).

To be so removed is both daunting and freeing, both for those removed and those remaining. For "if liminality is regarded as a time and place of withdrawal from normal modes of social action, it can be seen as potentially a period of scrutinization of the central values and axioms of the culture in which it occurs" (Turner, The Ritual Process 167). It is within this "antistructural liminality," this moment outside the lines, that "suppositions, desires, hypotheses, possibilities, and so forth, all become legitimate" (Turner, The Ritual Process vii). To be outside, then, is to challenge, wittingly or unwittingly, those who remain inside. In discussing Mary Douglas' work, Turner notes that she classifies anything outside the "terms of traditional criteria of classification" as "almost everywhere regarded as 'polluting' and 'dangerous,'” (Turner, The Ritual Process 109) ideas supported by Giorgio Agamben and Julia Kristeva. Agamben places the danger at the level of the State in The Coming Community: "For the State...what is important is never the singularity as such, but only its inclusion in some identity, whatever identity (but the possibility of the whatever itself being taken up without an identity is a threat the State cannot come to terms with)" (85). Kristeva, however, leans more toward the idea of pollution than danger, and places the disruption on the level of the individual and his surroundings. For Kristeva, to choose to be outside, to deny boundaries, is to be the "deject," the one "by whom the abject exists," and the one "who places (himself), separates (himself), situates (himself) and therefore strays instead of getting his bearings, desiring, belonging, or refusing" (original emphasis, Powers 
of Horror 8). Regardless, Turner, Douglas, Agamben and Kristeva note the immense power of disruption that surrounds those who reside in liminality.

This project examines plays that use and manipulate the liminal. To be liminal is to be outside time, both seen and unseen (or perhaps more clearly_-both recognized and not recognized). By “suturing” (Homi Bhabha's term) moments together, these dramas generate liminal moments - moments that recall the past in the present, making us see both, making us see each through the other. Homi Bhabha gives this relationship a spatial reading: "The stairwell as liminal space, in-between the designations of identity, becomes the process of symbolic interaction, the connective tissue that constructs the difference between upper and lower, black and white" (Bhabha 5). Understanding the liminal in this way, it becomes readily apparent that the sides of the threshold are dependent on each other. The stairs must both originate and terminate somewhere. Similarly, there is an interdependence between original and revision here-a dual dependency: neither text makes full sense without the other once the revision is discovered. Once the revision is written, the pathway between the two is irrevocable. We cannot see Mama Younger without Bessie Berger, nor Bessie without Mama. They are at once each other and each other's opposite. Their motivations and understandings may be different, but both are trying to find the future via a redefinition of their past and present.

Moreover, these dramas are doubly liminal as the theater itself is a liminal space. The stage employs dramatic (or suspended) time, replacing the typical Western chronological understanding of time. While the viewer exists in the theater and in the play itself, s/he has the opportunity to explore and create meaning. In the liminal, the past and present merge into one another in a neither-past-nor-present, neither-here-nor-there space; or, put otherwise, 
the liminal generates a hybrid space, one that is "neither the one thing nor the other" (Bhabha 49). It is here that the viewer can negotiate the moments, see the connections, and explore the possibilities generated by this moment of crossing. The second half of each chapter will examine these moments of transition and challenge.

My project will conclude with a review of the intentions and effects of these dramas. Examining how the playwrights saw their work, the role drama plays in the political, and the relationship between these plays and modernism and postmodernism, the conclusion posits these pieces as always interstitial and consistently challenging existing notions of art, history, and our understanding of both. 
CHAPTER 1: CONFESSION AND CRIME, CONFESSION AS CRIME: WILLIAMS' TITUBA 'S CHILDREN AND MILLER'S THE CRUCIBLE

Both Arthur Miller and William Carlos Williams reacted to the "witch-hunts" of the House Un-American Activities Committee (HUAC) and McCarthyism by writing plays that called forth an earlier dark time in American history: the Salem Witch Trials. Both plays intentionally blur the line between historical accuracy and creative license, using each historical moment as fuel for criticism of the United States and as a demand for change. Reflecting on McCarthyism in 1989, Arthur Miller questioned, "Why was there so little real opposition to this madness?” (“Again They Drink") and that question founds and guides both Miller's The Crucible and Williams' Tituba's Children.

Intrinsic to Salem, the HUAC, and McCarthyism were deeply-rooted suspicions, the act of confession, and a blatant disregard for American principles in the name of the nationalistic preservation. Historically (and dramatically), these moments and these plays all follow Turner's schema for a breach and its aftermath; the dramas employ the liminal as a means of stitching together the past and the present. This chapter will begin with an overview of the historical precedents, and then turn to an analysis of Tituba's Children and The Crucible.

\section{Defining the Social Dramas of the Historical Precedents}

For plays that rely explicitly on historical events as precursors-including Tituba's Children and The Crucible - the original breaches and their consequences that begin the cycle of the social drama are easily identifiable and readily apparent. For Williams and 
Miller, their use of the Salem Witch Trials in conjunction with the "witch-hunts" of McCarthyism provides a double-breach, or a breach reminiscent of an earlier breach. Both Williams and Miller argue that the past is never over, or in Turner's terms, the breach is never fully resolved, and therefore the past is able to re-enter and re-disturb society as conditions permit. By layering the HUAC/McCarthyism over the Salem Witch Trials and by calling these two moments not only similar but interwoven (reliant on the same principles and types of people), Williams and Miller increase their criticism of the past and the present, those involved in both situations, and those who were complicit in their failures to stop the hysteria (which includes almost all members of the society at large).

Applying Turner's theory, we can begin to understand that these are not isolated historical moments, but rather a result of our own failure to find resolution from an original breach. History does not, in Turner's view, simply repeat itself: such repetition is something we bring upon ourselves by failing to achieve resolution or final consensus. For Miller and Williams, who openly criticize the originators of the breaches, such a repetition is not only shameful, it is verging on the obscene as it is driven by whim, not reason, as seen in Miller's description of McCarthyism: "I saw the civilities of public life deftly stripped from the body politic like the wings of insects or birds by maniac children, and great and noble citizens branded traitors, without a sign of real disgust from any quarter" (Miller, Timebends 312). His disgust — as well as Williams'_-for these actions plays out in The Crucible and Tituba's Children via new interpretations of the Salem Witch Trials.

\section{Salem Village}

The Salem Witch Trials were "possibly the most celebrated of all witch-hunts" and certainly among the best known (Starkey 14). All told, 20 "witches" were executed in Salem 
in 1692 and Marion L. Starkey argues that Salem's "numerical modesty," when compared to the numbers of "witches" executed across Europe before and during this time frame makes it particularly resonant for modern readers, scholars, historians, and enthusiasts: "It is a manageable episode in a way that catastrophes involving astronomical figures are not" (Starkey 14). Because we can "know" the people involved in the trials, we can begin "grasping the local" as a means of "understanding the universal" (Starkey 14-15).

The Salem Witch Trials originally began with the odd behavior of several young women in Salem Village. Many in the group were alleged to be seeking the counsel of Reverend Samuel Parris' slave, Tituba. Both Charles Upham and Marion Starkey, the leading Salem historians available to Williams and Miller at the time, suggest that Tituba was involved in what would have been perceived as the dark arts, but modern theorists and historians disagree vehemently with this idea, noting that these assumptions have been based more on racism and assumption than documented fact. ${ }^{10}$ When one of the youngest participants, Reverend Parris' own daughter, began to show signs of absent-mindedness and trance-like behavior (sources allege that her behavior appears to have been legitimate at first), several local children began mimicking — and amplifying — the behaviors that were soon seen to be signs not only of "contagion," but "the torments of the damned"11 (Starkey

\footnotetext{
${ }^{10}$ Chadwick Hansen's "The Metamorphosis of Tituba, or Why American Intellectuals Can't Tell an Indian witch from a Negro" and Elaine G. Breslaw's "Tituba's Confession: the Multicultural Dimensions of the 1692 Salem Witch-Hunt" both use the historical record from the Salem Witch Trials to demonstrate that the types of witchcraft feared and discussed in Salem closely resemble English myths and not those of Tituba's native Caribbean. Hansen in particular argues that the assignation of blame to Tituba is the result of racist thought and not supported by the history.

${ }^{11}$ Starkey and Upham, along with many modern scholars, are both convinced that the children's behavior - with the possible exception of the initial instance seen in Reverend Parris' daughter-was contrived as means of receiving attention, getting out of chores, and
} 
40). The combination of physical and spiritual corruption signified a dire threat for the faithbased community.

As the number of "afflicted" girls and young women grew, so did the fear of witchcraft in Salem, and the breach — and subsequent crisis—officially began, pitting neighbor against neighbor. If the girls were damned, then such damnation must have been brought upon them due to the failings of the town. Given the pressures placed on Salem (and the emerging nation generally) to not only be successful, but to be successful as a "company of Christians not only called for but chosen, and chosen not only for heaven but as an instrument of a sacred historical design," this outbreak of witchcraft was not only disturbing, it was a sign of greater community-wide malady and failure (Bercovitch, The American Jeremiad 7-8). As Upham notes, "The moral force engendered in the civilization planted on these shores, and pervading the whole body of society, supplied a mightier momentum, as it does to this day, and ever will, to the movement of the people, acting in a mass and as a unit, than can anywhere else be found" (464-465; vol. 1). The pressure of creating a sacred, chosen community carried with it the possibility (if not probability) of breakdown and hysteria.

This social drama — and this breach in particular — was not, thus, unprecedented or unpredictable in Salem. A deep fascination with sin, confession, and guilt can be traced to the Puritanical roots of American society, as argued by Sacvan Bercovitch:

God wanted them to experience the slime: "he will have our hands actively in it' - and in it nor for 'one instant but [for] the whole course of a man's life.' We must be 'soaked and boiled in affliction,' as Job was, or Nehemiah, if we

breaking the boredom and monotony that surrounded the lives available to young girls of the time. Other theories exist, from encephalitis to hysteria to poisoning from fungus found in rye bread, but given the apt timing of each "affliction," it seems unlikely that there was an actual physical cause to the "illness." 
would 'have some relish acceptance unto god'; we 'must goe under the Flaile, the Fan, the Milstone, and the Oven, before [we] can be Gods Bread.' Would you wash your face clean? asks John Bunyan-well, 'first take a glass and see where it is durty': 'labour' to discern your every crime, 'experimentally' persuade yourself that you are 'the biggest sinner in the world,' 'plunge' yourself into the foul waters of your heart till you know there is 'none worse than thyself.' (original emphasis; Bercovitch, The Puritan Origins 14-15)

For the Puritans, admitting sin, indeed finding sin in oneself and confessing it for God's review and punishment was required: "In their case, they believed, God's punishments were corrective, not destructive. Here, as nowhere else, His vengeance was a sign of love, a father's rod used to improve the errant child" (original emphasis; Bercovitch, The American Jeremiad 8). Sin and witchcraft may have been evil, but its "corrective" punishment from God was divine, reaffirming the Puritanical belief in a blessed and righteous society. The breach was, then, an almost necessary outlet in Salem - a way of tackling ongoing issues in the community via a cathartic, if deadly, purge.

Fearing the worst following the initial "outbreaks" among the young women, Salem community members quickly entered into the crisis. They began using "leading questions" with the girls, encouraging them to formulate accusations of witchcraft and undue influence (Starkey 47). Thus the accusations began, at first covering only three women, including Tituba. Upham notes "the selection of the first victims was well made" as these women, all outsiders in some way, "were just the kind of persons whom the public prejudice and credulity were prepared to suspect and condemn" (34; vol. 2). The crisis initially appeared to be headed for quick resolution as the village established trials to handle the witches and cleanse the town.

But, during the trials, Tituba did what the others would not: she confessed, telling "Salem Village exactly what it wanted to hear" (Starkey 58) after being "either beaten [...] or 
severely pressured" (Breslaw 540). It is perhaps not surprising then that in Salem, one of the best ways to avoid execution — and possibly to avoid trial altogether — was the act of confession itself. $^{12}$ Of course, that act of confession had to be followed by the seeking of forgiveness and the implication of others involved in witchcraft, a lesson Tituba learned quickly. ${ }^{13}$ Tituba noted that she saw nine other names written in a book believed by the court to be the ledger of the devil. While her confession and repentance saved her life, the witchhunt was now far from over. The accusers took their cues and "continued to suffer torments and fall in fits" (Upham 37; vol. 2). Redressive means, meant to bring order in Salem, regressed instead back into a worsening crisis.

All told, more than 200 people would be accused of consorting with the devil, including well-respected townspeople, such as John and Elizabeth Procter, who feature prominently in the works of Williams and Miller. Of those accused, 19 "witches," men and women alike, were hanged by the end of the hysteria, including John Procter. Another alleged witch, Giles Corey, was pressed to death by stones for refusing to enter a plea. Several victims, particularly women, were convicted and sentenced to death but were not executed (often due to pregnancy), including Elizabeth Procter. The trials and executions would eventually serve as an uneasy form of resolution in this social drama — albeit a deadly one.

\footnotetext{
12 According to Wendel D. Craker, “...confession was the surest way to avoid trial," as, by "choosing to condemn themselves," the "witches" could denounce their sin and avoid being "justly punished via the noose by a paranoid society" (332-333). Confession, of course, whether in Salem or later before HUAC or McCarthy, also released the judges, investigators, and persecutors from the burden of proof.

${ }^{13}$ Tituba was convicted and put in prison, but never executed. Records show her eventual release after the hysteria had passed, although it is unclear what became of Tituba and her also enslaved husband who previously resided with her in Salem.
} 
Given the hysteria that surrounded Salem, and the fact that, as Tituba demonstrated, confession (and naming names) was often the safest route to survival, it becomes readily apparent how Salem reminded both Williams and Miller of the House Un-American Activities Committee (HUAC) and McCarthyism in Cold War America, and why the act of confession figures prominently in both their plays.

\section{The HUAC}

Although the HUAC and McCarthyism are often used synonymously, they were not directly related to one another. Originally formed to investigate Nazi propaganda in 1938, the HUAC became a permanent committee in 1946 and became more interested in the Communist Party than any other focus ("HUAC"). It is most well known for its 1947 hearings investigating alleged Communist propaganda in the Hollywood motion picture industry ("HUAC"). The Hollywood Ten, a group of subpoenaed writers and directors, were convicted of contempt of Congress (for refusing to answer specific questions posed by Committee members) and subsequently given prison time and blacklisted by the industry ("HUAC"). The hearings began a panic in Hollywood. Most studios issued statements announcing they would not employ a Communist or a member of a subversive party. The HUAC compiled a list of more than 300 supposed Communist Party members or sympathizers; some were called to testify; many were boycotted ("HUAC"). When called before the HUAC, most witnesses had three options: they could deny any involvement in the Communist Party (and face potential perjury charges since most were there because someone had already "named" them); they could admit involvement and be forced to name names; or they could plead the Fifth and be boycotted. 
This wave of anti-communist/anti-socialist fervor can be seen as a breach in and of itself. However, it could also be seen as the result of an ongoing, unresolved breach and crisis that had existed in the United States since the turn of the century (or, as Miller and Williams try to argue, since the Salem Witch Trials). Both the large influx of immigrants between 1908-1914 and World War I led to a generalized fear of the "other," and potentially anti-American or un-American ideas, such as socialism and communism. The Red Scare, the execution of Sacco and Vanzetti, and the extreme tactics of J. Edgar Hoover and the Federal Bureau of Investigations demonstrate that this original crisis, rather than finding resolution, continued to bubble under the surface, aided by those who benefitted from the ongoing crisis. Indeed, there has been no clear end to this ongoing crisis. The HUAC and McCarthy's investigations, like the Salem Witch Trials, ran their course, but they lack the distinct redressive means and resolution of Salem. The trials and boycotts did little to permanently assuage a suspicious population. The Cold War continued well beyond the HUAC and McCarthy himself, driven by a continuing distrust of all things potentially antiAmerican. And, given the tenor of the political rhetoric of the 2012 Presidential election, including the Conservative Right's significant fear and loathing of the allegedly "socialist" policies of President Barack Obama, it is clear that this intrinsic fear of "un-American ideas" is not as far behind us as we may have thought. While Fox News is generally assumed to carry a strong conservative bias, their 2012 survey of 1,012 registered U.S. voters records this ongoing fear, perpetuated by the survey itself: "61 percent of U.S. voters are concerned that Obama administration policies 'will move the country toward socialism'; 89 percent of Republicans and 38 percent of Democrats agree with that" (Harper). While the sample size is too small to be representative and the questions themselves are leading, the sentiment 
captured reflects an ongoing distrust $—$ a persistent and powerful crisis still in search of resolution. ${ }^{14}$

\section{McCarthyism}

During the 1950's, Senator Joseph McCarthy himself was a symptom of this ongoing crisis, and his quick advancement and public prominence stemmed from his distinct ability to feed the flames of dissent by manipulating the fears of others. Separate from the HUAC, he was often more concerned with larger issues, including Communist influences in the U.S. Army and the U.S. State Department. His hugely inaccurate speeches and public bullying tactics led, however, to this red-baiting era often being referred to as the McCarthy years or McCarthyism. ${ }^{15}$ McCarthy is well known for his 1950 claim that 205 United States State Department employees were members of the Communist Party. For several years, he used similar claims and subsequent investigations to keep his own name at the forefront of the new witch-hunt in America. Journalist Irving Kristol attributed McCarty's success to a simple fact: "there is one thing the American people know about Senator McCarthy; he, like them, is unequivocally anti-Communist" (Irving Kristol qtd. in Saunders 207). McCarthy

\footnotetext{
${ }^{14}$ McCarthy himself, is too, it seems, not far from the American imagination. Washington Post Opinion Writer Dana Milbank published a February 26, 2013 editorial about the confirmation of Senator Chuck Hagel titled "A filibuster fit for McCarthy" in which he criticized the smear tactics used by Republicans during the confirmation hearings, including the twisting of Senator Hagel's comments on the 2006 Lebanon War to make him sound antiSemitic. Of the misquoting, Milbank wrote, "It was one of many moments from the past few weeks that Joe McCarthy would have admired" (Millbank).

${ }^{15}$ The term "McCarthyism" has taken on a subsequent life of its own. Wikipedia.com, while not an academic source, nonetheless has far-reaching influence and a large audience; it defines "McCarthyism" as "the practice of making accusations of disloyalty, subversion, or treason without proper regard for evidence" or "reckless, unsubstantiated accusations, as well as demagogic attacks on the character or patriotism of political adversaries"

("McCarthyism"). Indeed, the online encyclopedia does not even mention Senator McCarthy himself until line four of its definition. The term has surpassed its namesake.
} 
certainly was not alone as the nation feared its enemies abroad and thus turned on its neighbors at home: "Unable to strike directly at the Russians, the most vigilant patriots went after the scalps of their countrymen instead" (Whitfield 9). McCarthy would eventually push too far; his televised "investigation" of U.S. Army officials in 1954 led to his censure for "Abuse of a Senate committee" and the decline of his influence ("The Censure Case"). The Relationship Between Past and Present

The initial moments of breach that led to the Salem Witch Trials and the HUAC/McCarthyism era are eerily similar. Garry Wills, in his introduction to Scoundrel Time, argues that what happened with McCarthy and the HUAC grew out of America's love for total war - a war that had saved us from the Great Depression while instilling Americans with a sense of purpose and high moral duty. As in Salem, the community was purging itself of its dangerous elements to create a more perfect union. In both cases, a need to protect the whole via the damnation of the parts — even when those parts were potentially innocentsuperseded all else.

Salem and the HUAC/McCarthyism also exemplified what Richard Hofstadter has deemed the "Paranoid Style in American Politics." Those caught up in this form of paranoia are "overheated, oversuspicious, overaggressive, grandiose, and apocalyptic in expression," much like those involved in the hysteria surrounding the witches in Salem and the Communists in the State Department (Hoftstadter 4). Focused on the health of the community (versus the health of the self in the case of true, clinical paranoia), he who is caught up in the paranoid style believes "his political passions are unselfish and patriotic," feelings that "intensify his feeling of righteousness and [...] moral indignation" (Hofstadter 
4). As the histories of Salem and the HUAC/McCarthyism demonstrate, righteousness, parading as patriotism, is a dangerous mistress.

Such a view of Salem and the HUAC/McCarthyism is simultaneously accurate, idealistic, and insufficient, however. Despite the desire to eliminate the transgressors and purge the traitors for the sake of an ultimate, holy society in Salem, some scholars and historians have suggested the hysteria was driven by more self-serving motives. The young girls in Salem were, at best, bored young women caught up in "forbidden pleasures" and the subsequent attention of the town; they were at worst intentionally malicious and unconcerned with how their whimsy ruined people's lives (Starkey 39). The townspeople caught up in the accusations who supported and encouraged the purge of Salem were at best caught up in the wave of fear, attempting to bring sanctity to Salem; they were at worst involved, neighbor against neighbor, in order to obtain the spoils of their vengeance - the money, land, livestock, and materials—-left behind by the accused and hanged. As Starkey notes, "Under the law witches were to be treated like enemy aliens found guilty of conspiring against the government under which they lived; not only their lives but their goods were forfeit" (96). And while convictions were supposed to precede seizures, sometimes "a zealous sheriff overlooked this technicality" (Starkey 96). The Procter's "goods, provision and cattle," for example, were seized and distributed before their trial, leaving their children without food and shelter (Starkey 96). Scholars have even questioned the motives of Reverend Parris, the magistrates, and the clergy, both in Salem Village and those who arrived from elsewhere in Massachusetts to assist. The Salem Witch Trials, after all, were a prime position from which to assert—and retain— power. 
The accusations made against the HUAC and Senator Joseph McCarthy have been even less forgiving. The damage done by these two forces was long lasting and indeed their legacies can still be felt today. McCarthy himself was, for several years, unstoppable, destroying anyone in his path. ${ }^{16}$ Journalist Cabell Phillips described him in the following fashion:

He spit in the eye of constituted authority, undermined public confidence in the government and its leaders, and tore at the nation's foreign policy with the indiscriminate ferocity of a bulldozer. He used lies, slander, and innuendo to smash his opponents and to build his own image of invincibility. He made cowards of all but a handful of his fellow Senators, and he kept two Presidents angrily and helplessly on the defensive in nearly everything they did. (qtd. in Whitfield 38)

All of this power was retained by a man who "never found a real Communist on his own" (Whitfield 38). Indeed, a reporter allegedly said McCarthy “"couldn't find a Communist in Red Square" (qtd. in Whitfield 38). Ultimately, for all their desire to strike down the Communist transgressors and retain only the patriots, both the HUAC and Senator McCarthy ultimately attempted a decidedly un-American action: to sanction citizens for their thoughts and their speech.

This distrust of the very citizenry that puts leaders in place further joins the HUAC, Senator McCarthy and the Salem Witch trials. The committees in all three instances were interested in those who would name others involved in "evil" acts against the solidarity of the community, whether witchcraft or Communism. And while McCarthyism and the HUAC may not have led to hangings, they did lead to the destruction of many lives and livelihoods

\footnotetext{
${ }^{16}$ Hofstadter sees McCarthy as a special kind of paranoid spokesman, a member of the disenfranchised right who "feels dispossessed: America has been largely taken away from them and their kind, though they are determined to try to repossess it" (23). Thus, the modern participant in the paranoid style is driven both by his alleged fear of the enemy, and his fear of ceasing, politically, to matter.
} 
via blacklists, fines, jail time, and ruined reputations. As Miller points out, "It was quite the same excepting we weren't hanged, but the ritual was exactly the same. You told them anyone you knew had been a left-winger or a Communist and you went home" (qtd. in C. Bigsby xvi). The decision — to suffer oneself or to bring the suffering down on others — was both devastating for those who desired no part in the crisis, and empowering for those who wished to bring damnation on others. As in Salem, the crisis that wields devastation also wields desire.

\section{The Act of Confession, the Definition of Crime}

This idea of confession - so prevalent in both "witch-hunts," was more than just an ongoing part of the breach and its crisis. Instead, in both historical moments, the act of confession was itself a moment of redress and on its way to resolution, for the confession served a distinct, if disturbing, social function. Confessing a crime, according to Foucault, equates to audibly accepting and reaffirming the judicial/moral/societal/religious structure that outlines the difference between good and bad, sinners and saviors, right and wrong. As Foucault notes, through varying countries and time periods, "The criminal was asked to consecrate his own punishment by proclaiming the blackness of his crimes," and "If these accounts were allowed to be printed and circulated, it was because they were expected to have the effect of an ideological control" over those who heard or read the confessions (Foucault 66-68). Thus members of Salem and those tried before the HUAC/McCarthy are coerced into confessing not only because it cleanses the society of sin, but also because it reaffirms the power structure of the society itself. Via the destruction of the individual—and most often in these cases the innocent individual — the society finds its reaffirmation and its wholeness. The HUAC and McCarthy attempted to use Congressional and other State- 
sponsored means as redressive machinery, leading to their resolution—a purged America. The clergy and magistrates of Salem attempted the same methods: confession would feed the crisis, but it would also eventually cleanse the village, leading to redress and resolution.

Part of the purge rested on the sheer public nature of the persecution as the spectators in both time periods became "...increasingly excited" because "they think they have unearthed a guilty party, a scapegoat" (Kristeva, The Sense 5). And yet, as Julia Kristeva points out, the crime and its punishment are more about social order than justice:

Crime has become theatrically media-friendly. I do not contest the benefits of this situation for democracy: perhaps we have in fact arrived at a so-called liberal society in which there is no surveillance and no punishment except in these theatrically mediatized cases that become a sort of catharsis of the citizen's nonexistent guilt. Though we are not punished, we are, in effect, normalized: in place of the prohibition of power that cannot be found, disciplinary and administrative punishments multiply, repressing or, rather, normalizing everyone. (Kristeva, The Sense 5)

Certainly the Salem Witch Trials and the HUAC hearings had actual punishments. But they also were highly theatricalized, and highly symbolic, working through the "guilty" to instruct the spectators, making sure that society was God-fearing, country-loving, and hating all the right enemies, even when those enemies were within the national (or village) borders.

\section{Fighting Back}

It is against this momentum that Williams and Miller push. Is it at all surprising that even if the majority was assuaged by such methods, a minority remained, outraged, looking for outlets and attempting to recreate a breach, one that, this time, may turn the tables against the persecutors? Williams and Miller struck back to demonstrate the repetitive follies of a society driven by fear, coerced confessions, and an intrinsic need for catharsis-by-crisis. Instead of confirming the naturalizing order of community purging, Miller and Williams see the destructive power of such tactics, leading Miller to question if his play's ongoing 
popularity has to do with "its symbolic unleashing of the specter of order's fragility" (Miller, "Again They Drink"). That fragility, intrinsic to the history of the Salem Witch Trials, the Red Scare, the HUAC, McCarthyism and indeed all moments of community-wide hysteria, generates the backdrops for these plays. Williams and Miller employ revision, and particularly moments of liminality, to highlight the moments of connection and human culpability behind the devastation.

More than simply questioning, however, Miller and Williams participate in ongoing redressive means as an attempt—albeit a demanding, angry attempt — to approach resolution. Theater, for Turner, is a way of showing society itself, in all its brutality. As theater is liminal in and of itself, it provides "a time and place of withdrawal from normal modes of social action, it can be seen as potentially a period of scrutinization of the central values and axioms of the culture in which it occurs" (Turner, The Ritual Process 167). This moment of pulling back is also a means of pushing back. And yet, it is not just theater, as ritual, as liminal, that probes our failings: "At every moment, and especially in the redressal of crises, the meaning of the past is assessed by reference to the present and, of the present by reference to the past; the resultant 'meaningful' decision modifies the group's orientation to or even plans for the future, and these in turn react upon its evaluation of the past" (Turner, The Anthropology 98). Williams and Miller thus use the theater as a demand to understand past and present, and as a refusal to accept either as sufficient, just, or good.

\section{Tituba's Children: The Breach and the Liminal}

Play Summary and Production History

Written in 1950 (three years before Miller's The Crucible) but published after The Crucible in 1961, Williams' Tituba's Children begins in Salem with a driven, calculating 
Abigai $1{ }^{17}$ who forces Tituba, her friend's nurse/servant from the Bahamas, to help her prove the presence of the Devil in Salem. The play quickly morphs from the small town of Salem to a Washington, DC club on Halloween night in 1950, but much of the stage décor remains the same, clearly indicating the continuity between past and present.

The modernized sections of the play focus on State Department Under-Secretary "Mac" McDee and his mistress, club hostess Stella Rajaputsky. It becomes clear that Mac is being pursued as a suspected member of the Communist Party. Simultaneously, Stella and the club employees are staging a Halloween re-enactment of the Salem Witch Trials and the already delicate separation between past and present disintegrates further on stage as actors play characters in both time periods. Williams, however, further complicates the veil between past and present by inserting large excerpts from Upham's and Starkey's histories of witchcraft in Salem, from 1867 and 1949 respectively, directly into the script. While there are no stage directions for the historical excerpts, given their inclusion, it can be assumed that Williams intended them to be part of the drama, either in print form or as readings by a character or a narrator on stage.

As the charges against Mac become evident, the play itself continues to move between stagings of the actual witch trials and the trial of Mac, as a chorus enters Mac's courtroom, singing, among other verses, "Must this terror be repeated?" (Williams 289). Mac's trial is eerily reminiscent of the previously staged Salem Witch Trials as the judges demand, as they did in Salem, that the transgressor confess. When he refuses, he is indicted and arrested, and the chorus returns to sing of the murders of the Salem witches. Despite the presence of the

\footnotetext{
${ }^{17}$ Abigail is clearly meant to represent Abigail Williams, an eleven year old girl who was one of the main accusers in the Salem Witch Trials. In volume two of his extensive 1867 history on Salem, Charles W. Upham notes that Abigail was, "in many respects, the leading agent in all the mischief that followed" (Upham 3).
} 
historical text, Tituba's Children is not a historical re-enactment as Williams clearly takes creative liberty with the creation of Mac and Stella, as well as with the intentions, motives, and thoughts of Abigail, Tituba, and the others present in the original Salem Witch Trials.

There are no known professional stagings of Tituba's Children, perhaps due to the confusion regarding how to integrate the excerpted historical writings, the overly didactic tone of the play, and/or, most likely, Williams' delay in releasing Tituba's Children, during which time The Crucible was produced. There have been small-scale productions of the play, including a 1972 production at the University of Missouri and a 1986 high school performance by the New York State Literary Center. Tituba's Children has received very little critical attention over the years. Williams is, of course, best known as a poet, and this play certainly has its weaknesses - including the already mentioned didactic insistence on the lessons of history, as well as moments of unclear stage direction—but its attempts to revise history as a way of better understanding the present are important to this project.

\section{Opening Moments}

Before the play even begins, Williams introduces the text's relationship to-and departure from-history. Williams' list of characters that opens the textual representation of his play reveals the dualistic and revisionary motive of his work. The first list, titled "Salem, Massachusetts: 1692" includes a historically accurate list of characters and descriptions, from "Betty Parris... aged 9," to "John Procter, a farmer living near Salem Village" (226). Following the list of 23 predictable characters, however, Williams also lists "A Physician. Constables. Townspeople. Judges. Demons," and the shift into something less predictable begins (226). Williams also includes a list of characters from "Washington, D.C.: 1950," and following his list of nine characters, including "Stella Rajaputsky, hostess in the restaurant of 
the National Club. About 25" and "Mac' McDee, a young official in the State Department. About 30," he notes, "Many of the parts in the Salem and Washington scenes are played by the same actors - with change of costume, but intended to be recognizable as the same persons. Salem magistrates become Washington senators, Stella plays Sarah Good in one sequence, etc.” (227). Thus the characters themselves are split, at once representations of two times.

Both Williams and Miller position the openings of their plays alongside the opening of the historical breach in Salem. This decision serves as a way of dropping the viewer immediately into the action. It also allows both playwrights to make a decisive point: the moments leading up to the accusations of witchcraft themselves are insignificant; they are not worth noting. Both Williams and Miller imply that the breach is driven not by reason but by jealousy, blindness, boredom, and maliciousness, and as such that which leads to the breach is arbitrary and senseless. By discrediting the accusers in Salem, Williams and Miller both attempt to discredit the accusers in their own time. They are understood through the lens of the past; they are discredited and dismissed via the very same lens.

Williams relies on, and alters as necessary, the historical texts available to him at the time. Both Upham and Starkey note that Betty Parris, the daughter of the Reverend, was the first girl to exhibit physical "symptoms" attributed to her being bewitched. And yet, both also note that Betty was without guile; Starkey calls her "a really sweet, biddable little girl, ready to obey anyone who spoke with conviction, including, to her misfortune, her playmate Abigail" (23). Abigail, according to Upham, was a "niece of Mr. Parris, and a member of his household" who "acted conspicuously in the witchcraft prosecutions from beginning to end" (Upham 3; vol. 2). Starkey is less open-ended in his description: "from the eyes of this child 
an authentic hellion looked out on a world it would make over if it got a chance" (23).

Williams clearly relies heavily on Starkey's description, as Miller does in his later version. While Williams' Betty is fearful and skittish in the opening lines of his play, Abigail is determined to work with Tituba, somewhat ironically, to make a "witches" cake" to help them discover "if there be witches preying here and if so who they be" (229). Within the very first moments of the play, Abigail threatens Betty, who wants to call for her mother: "I'll kill her if she bothers us! [She puts her hand over her little cousin's mouth.]. But I will know the truth—you can't stop me. I'll say you are bewitched" (229). Williams gives Abigail absolute power — not far from the power she possessed in actual Salem—and foreshadows the accusations to come. Abigail, for Williams, is the breach. By beginning the play at the outbreak of the accusations, Williams immediately puts the audience in that originating moment. His characterizations leave the audience with little doubt regarding which side they are meant to take in the quickly ensuing crisis.

Williams gives the audience an understanding of Abigail that the "audience" of the original social drama did not have — or at least the majority did not have. While there were certainly those, such as John Procter, who doubted the verity of the girls' claims ${ }^{18}$, the original "audience" did not have the gift of hindsight. The audience of Williams' drama is consistently warned in the opening act of Abigail and the girls' true intentions. Tituba tells Abigail "You got the Devil in you! You don't give me no peace!" (236). As the first scene

\footnotetext{
${ }^{18}$ Procter's maidservant, Mary Warren, was one of the accusing girls. Early in the proceedings, Procter "was reporting that he had cured her fits by plumping her down at her spinning-wheel and promising her a thrashing if she stirred from it, in or out of possession" (Starkey 63). Mary Warren would eventually admit that her episodes were false: "It was for sport. [....] I must have some sport" (Starkey 92-93), only to recant when the girls tried to turn against her. She would ultimately claim that both Procter and his wife were involved with Satan, presumably to save herself from the wrath of her fellow accusers, and potentially for "sport" and revenge.
} 
closes, Williams introduces physical demons onto the stage after Abigail begins barking like a dog —one of the "symptoms" the girls use to demonstrate they are being attacked by witches: "At this point, black young demons, some wearing dog masks, begin to come out of the dark corners of the fireplace. They caper about the fire, but the girls do not see them" (239). The audience, of course, does. As Abigail closes the scene promising that those who "torment" her "shall hang for it," the "demons dance about her with great glee. As the curtain descends, she joins them" (240). Such a joining leaves Abigail no room for redemption in Williams' play. Her accusations — and the subsequent havoc they wreak - are as intentional as they are false. That Abigail dances with "great glee" with the demons leaves little doubt as to her allegiances. ${ }^{19}$ She is the originator of the breach, and thus the breach loses its moral superiority, if not its power.

The Liminal and the Scapegoat

The demons themselves spring from the large fireplace that rests on stage. It is within the deep walls of the fireplace that Tituba hides from her angry master in the opening scene as well. This fireplace - where the family's meals are cooked, where the "witches' cake" is baked, where Tituba hides from a whipping and from which the demons emerge - is at once the sign of domesticity, treachery, safety and peril. It is also the first truly liminal element in the play. When scene two opens, the audience is shown a "modernized" 1950 s "club restaurant in Washington, D.C." (240). While the stage has changed significantly, the fireplace remains, this time "decorated with pumpkins and cornstalks" (240). The slippage between past and present via the presence of this loaded symbol—both in terms of its multiple meanings in the Salem home and in terms of its generational capacity as starting

\footnotetext{
${ }^{19}$ Later in the play, Williams will note that the accusing girls themselves "were made heroines, excited brats and trollops that they were" (Williams 253).
} 
point for the original mayhem — forces the viewer to see the present via the past. The reader/viewer knows that this fireplace takes on a personified, duplicitous role: its food can nourish and destroy; its walls can protect and damn. Recalling the past, Williams intimates, is not a passive endeavor for, as Bhabha states, "Remembering is never a quiet act of introspection or retrospection. It is a painful re-membering, a putting together of the dismembered past to make sense of the trauma of the present" (90). To see the fireplace is to carry its weight forward into this scene, this time.

It is in front of this very fireplace that Mac informs Stella, with whom he is clearly carrying on an extramarital affair, "they're out to break me" and "The very vagueness of the charges makes it suicide for me to answer them" (243). The audience is not given many other details; we are not informed who "they" are or what "charges" are being levied against Mac, but the implications are clear. Given the time frame, the fact that Mac is a "State Department under-secretary," and the ominous presence of the fireplace, the reader/viewer is asked to draw the connections between Salem and the HUAC (241). Indeed, Stella's first response is "Another witch hunt, huh? I know their kind" (243). As the audience has seen the conniving evil behind the first set of false claims in the preceding "witch hunt," Williams does not need to give Mac and Stella much actual stage time, nor does he spend time with prolonged character development of these two protagonists. They are presumed innocent based on their very position as victims in the witch-hunt. Again, the audience may be dropped into the modernized section of the play mid-breach, but we are intentionally left little doubt as to which "side" we are to take in the crisis.

Stella is positioned in the play to know "their kind" well. As she talks to Mac, the rest of the cast moves around stage, preparing for "putting on a show" at the club "for the 
members," for "Halloween and all that_about the witchcraft trials at Old Salem" (243). Within the recreation of Salem, happening in front of the fateful fireplace, Stella plays the role of Sarah Good, the first woman accused in Salem, and one of the first to be hanged. Stella, then, becomes double-victim, both in her present, where she will eventually be accused of vague charges in order to force her to turn on Mac, and in her past, as Sarah Good. She herself is a liminal character, both because all actors occupy a liminal space on stage, and because she serves, more than any other character in Williams' play, as the stitch holding together past and present, the woman present in both times. She represents the sacrificial woman — one who can be tossed aside for the "good" of society, as Salem magistrates may have argued, or, as Williams would argue, for the whim of society. Her presence on stage, like the presence of the fireplace, is always symbolic of the duality consistently at work.

Sarah Good was a known outsider in the community and not one of the accused who garnered significant sympathy. Unlike Miller, who chose the upstanding and virtuous Procters as his focal point, Williams chooses a "forlorn outcast," one known as "shrewish, idle, and above all slovenly" (Starkey 50). She was also a poor beggar, and she was "accused of spreading smallpox, if not by malefaction, at least by negligence" (Starkey 50). Williams insinuates that she is knowledgeable of the girls' true intentions and character as she is seen in the opening scene telling Abigail “And the Devil spend you, young miss. You're a pert one. We'll meet again, my little bitch. You're the ringleader" (Williams 232). She is the outsider who is able to observe society from the margins, and as such, she is dangerous. She was historically, and is dramatically, the perfect object around which to center a crisis.

Good's status as a working woman, disease-spreader, and knowledgeable outsider 
marks her for ostracizing and even death as "The more signs of a victim an individual bears, the more likely [s] he is to attract disaster" (Girard, The Scapegoat 26). For Girard, this "disaster" has been repeatedly unavoidable (or at the very least, unavoided) historically. Societies are comprised of possible crowds, and "Those who make up the crowd are always potential persecutors, for they dream of purging the community of the impure elements that corrupt it, the traitors who undermine it" (Girard, The Scapegoat 16). The "dream" of "purging the community" focuses the destructive power on those who are marked as victims: "Ultimately, the persecutors always convince themselves that a small number of people, or even a single individual, despite his relative weakness, is extremely harmful to the whole of society" (Girard, The Scapegoat 15). For Girard, this predictable and repeating persecution is the act of scapegoating:

Everyone has a clear understanding of this expression; no one has any hesitation about its meaning. Scapegoat indicates both the innocence of the victims, the collective polarization in opposition to them, and the collective end result of that polarization. The persecutors are caught up in the 'logic' of the representation of persecution from a persecutor's standpoint, and they cannot break away. (Girard, The Scapegoat 39)

Sarah Good is easily made a scapegoat. The presumably adulterous Mac (and Stella) are also easily made into scapegoats. When Williams assigns these "disposable" characters the roles of protagonists in his play, however, and introduces demons onto the stage to mingle with their persecutors, he magnifies his criticism of the accusers. Deeply flawed as these characters are, they are still, Williams reminds us, undeserving of their fates. To force the audience to have sympathy for the otherwise unsympathetic is to alter the audience's view of the "crimes." 


\section{The Accusers and the Complacent}

Indeed, the naming of Mac's accusers intensifies the distinctive bifurcation between good and evil in this play. Whereas Williams uses the original names from Salem, the accusing Senators in his play_-“Gasser," "Wise," "Pipeline" and "Yokell”_ - are clearly

fictional, and meant to be ironic or demeaning (or, in reality, often both). The four Senators are seen in the club, gossiping and congratulating themselves on their successes: "Sit down, Charlie. I didn't see you standing there. How's the latest scandal? Moving up?" (Williams 246). Like those levying charges in Salem, these Senators fear outside influence while simultaneously profiting off that fear and its subsequent destruction. Yokell questions, "What kind of language are those colored kids talking to each other?" as he observes the staff of the club; he later insults the Italian club host, calling him one of the "Grease balls," asserting "I don't trust these foreigners" (Williams 247, 249, 251). Williams leaves no sympathy for these distrustful and disgraceful men who, like Abigail, find their upward mobility on the backs - and lives - of others.

It is amidst the complaints and racist musings of the Senators that the chorus of the play-within-the-play begins singing: "The pretty truth, / The Devil's truth, / plays upside down / with the whole world" (Williams 252). Williams inserts this chorus into the very words being issued by the Senators, thus marking them, and the Salem persecutors they resemble, as the "Devil," or at least the "Devil's truth." And yet, they do not share all the blame, for as the chorus continues to sing, they note, "The whole's the fault" (Williams 252). While Abigail and the Senators carry their share of responsibility, it is clear that the persecution of the scapegoat requires the failings of many:

A possible target need only be slightly more attractive than others for the whole group suddenly to come together in total agreement without the 
slightest feeling of doubt or contradiction. [....] Since in such cases there is never any reason for violence except everyone's belief in that other reason, it is enough for everyone to focus on that other reality, the scapegoat, who then becomes everyone's 'other.' (Girard, The Scapegoat 86)

It is the "whole group" that must unite behind the common - if ultimately arbitrary —enemy. It is the "whole group," whether the members of Salem or the complacent citizenry during the McCarthy years, who allow the crisis to continue unchecked. Indeed, during the playwithin-the-play, one of the accused witches, Sarah Cloyce, declares, "It is a shameful thing that you mind these folk...who are out of their wits" (Williams 255). As she makes the declaration, she "points angrily, directly at the audience of club guests," including the McCarthy-like accusing Senators, and, presumably, the actual play's real-life audience as well (Williams 255).

\section{Other Victims}

Sarah Good is not Williams' only victim. She is immediately followed by Sarah Cloyce, Elizabeth Procter, John Procter, and Giles Cory, who appear on stage in rapid succession. Each is interrogated and instructed to confess; each denies involvement and is quickly replaced without ceremony: "The Master of Ceremonies... gestures for Mrs. Procter to go away. Her husband takes her place" (Williams 256). The repeated—and denied— demands for confession dominate this act, but there is little differentiation among the characters. They become, in many ways, the same character, the same denial, the same fruitless appeal to sense and decency. Unlike in The Crucible where the confessions will build to a climax, these confessions feel heavy and repetitive, issued more by ghosts or specters than distinct people. In many ways, these characters are already dead—executed for their repetitive, absurd, lackluster moments on stage. Repeatedly demonstrating the same demands, the same responses, and the same outcomes, Williams shows the failure of these 
redressive means. They cannot find truth. They cannot find justice. They seem to care little who is before them. The search for confessions is insatiable, and it will consume these actors - both in their roles as Salem Villagers and in their roles as McCarthy-era Americans. Directly following this scene, the condemning chorus reappears, themselves liminal creatures who move between past and present, appearing during the play-within-the-play and during Mac's trial at the close of the actual play. Part of the scene and yet neither seen nor heard by the actors, they speak directly to the audience:

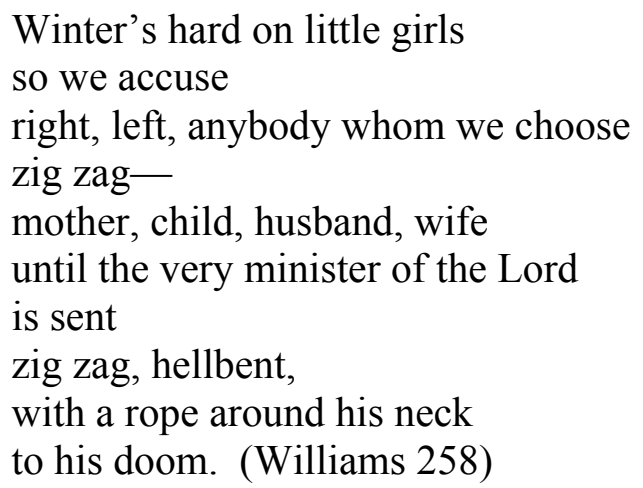

It is at this moment that Mac enters the club. The audience knows that he will be sent "to his doom" with a metaphorical "rope around his neck" and he therefore becomes, adulterer that he is, more of a "minister of the Lord" than the Senators, or actual Salem ministers, themselves. He will face the same demand for confession, and his answers will matter just as little. Williams thus posits that the means of redress that follow the crises - the trials, boycotts, and executions, are as tainted as the breaches themselves.

Mac's re-entry into the club following the play-within-the-play triggers Act II, which drops the viewer/reader back into Salem itself, returning to the trials of Sarah Good, Tituba, and others ("zig zag...zig zag..."). Williams uses the actual words of the accused, as represented in the historical transcripts (with some excerpting and additions) to drive this scene. Testimony after testimony follows and Williams demands that the director "must 
make it show the mass absurdity — the lack of real evidence, the unfairness of the legal procedures" (283). To do so, Williams suggests "Flashes of color, with the iron wills on both sides caught and dazzled by the 'wonder' of the whole" (Williams 283). This is not the wonder of an effective redressive means leading to salvation and resolution, however. It is the spectacle — and the "absurdity" - that is master.

\section{Collapsing the Worlds}

The accusations continue and the accused appear on stage in rapid succession—with the failing redressive means fully visible for all—until John Procter returns, declaring "Ye have all lost your minds - men who should know better are gone mad" (Williams 287). While these words may not have come directly from Procter during his trial, it is well documented that the sentiment was accurate: "John Procter had spoken so boldly against the proceedings, and all who had part in them, that it was felt to be necessary to put him out of the way. He had denounced the entire company of the accusers, and their revenge demanded his sacrifice" (Upham 312; vol. 2). As he finishes his fateful statement, avowing "I am innocent," Williams orders a "transformation" on stage as "Elizabeth and John Procter have become Stella and Mac" (Williams 287). The Salem magistrates become the Senators and "This process continues - quite openly and in full view of the audience, the actors shedding their Puritan clothes to reveal the modern dress beneath — until we have the principal figures of the Washington nightclub scene restored. About half of the on-stage audience, however, are still Puritans" (287). The liminal, the "in-between temporality" and "interstitial intimacy" are on full view as past and present become at once one (the united) and the "other" (the split, the foreign) (Bhabha 19). 
As past bleeds into present and present bleeds into past, the voice of Giles Cory, the one man who refused to enter a plea and was pressed to death by stones, fills the stage as a “half-muffled cry” comes from off stage, “More weight! More weight!” (Williams 288). Through this cry, a Senator asks Mac "have you ever been a member of the Communist Party?" (288). Mac, speaking as Cory's echo can still be heard, adds to the echo: "I refuse to answer" (288). As the court takes a recess, trying to force Mac into answering, the chorus reappears asking "Must this terror be repeated?" and noting "We thought that crime / had been expiated, that the devil days / would not come again" (289). The demand for confession continues, and it is continually thwarted; the outcome, we know, will be —at least metaphorically — the same. Williams reminds the audience "we have fouled our own beds" (289). The crisis, the redressive means, and the resolution, it seems, have not been expiated as Williams drives home our faults and our failings. Before the trial can resume, a disembodied and unidentified man's voice enters the stage, noting "We! We ourselves, who boasted so much of our democracy, were the very ones to blame" (290). Williams' play may be didactic and at times chaotic, but it is not unclear.

It is Stella who is called next, and the Senators ask her "Did you ever sign the book?" generating a clear link to the past, to Salem, and also serving as a nod to her earlier "role" as Sarah Good. When Stella seeks clarification, she is asked if she is a card-carrying member of the Communist Party. As Stella continues her denials, the Senators accuse her of having "fell designs" on Mac's wife, of hoping in her "secret mind that she might die" (Williams 293). When the Senators accuse Stella of keeping Mac from his wife and causing the stillbirth of their children, Stella faints with twitching limbs and rolling eyes. Her actions are eerily reminiscent of the accusing girls' behavior in Salem, but Stella is ironically one of the 
accused, not an accuser. For Williams, such distinctions seem no longer to matter. Her fainting also calls forth the chorus, who notes, "The past repeats itself. Oh what / is here foretold!" (Williams 294). Mac tries to bring the Senators to their senses, stepping in to allege, "I am a liberal. I am no Communist, nor am I a totalitarian in any sense" (Williams 198), but the Senators can only fixate on his refusal to admit his complicity and name others involved; he is indicted and arrested for contempt.

The play ends with the chorus, returned anew, singing of the murder of Giles Cory and his wife. Again, as in Salem, the redressive means fail, leaving the crisis to arise again at will. The demand for confession - the demand for the individual to assume and assuage the fears and doubts of a community_fails. Or, more succinctly, as Williams suggests, we fail.

It is via the play that we can view the structural, and personal, failures. It is via the play, as redressive means itself, that we can begin to realize "Though the hearts of our people are generous we have permitted searing corruption to dominate us. We are corrupt through and through" (Williams 290). Williams works to implicate the viewer in his play, suggesting that the breach works because we allow it. McCarthy and the HUAC, like the Salem Witch Trials, were not necessarily memorable for their scope or intent; certainly, larger, more destructive moments can be found in human history. They were, however, possible because the common citizen either got caught up in the hysteria or remained a silent bystander. Williams, like Miller, recognizes this failing and uses his play to demonstrate our shortcomings, likely in the hopes of finally ending the breach.

It is not easy to envision a resolution following this play, this form of redress. Turner tells us that "Where consensus over key values no longer exists, the redressive machinery premised on such a consensus loses its legitimacy, with the result that there is a reversion to 
crisis, with less likelihood of crisis \#2 being resolved by redressive machinery \#1" (The Anthropology 35). As Williams posits (and all other playwrights in this study will posit), the initial attempts at redress - in this case the trials during both time periods - failed. It is redress in the form of drama that seeks to return us to the crisis to start our work again. Only by re-engaging the crisis, understanding our own complicity, and attempting legitimate forms of redress, can we move towards something beginning to resemble resolution.

\section{The Crucible: The Breach and the Liminal}

Play Summary and Production History

Arthur Miller's The Crucible was first produced in 1953 and saw considerably more success than did Williams' version of Salem and McCarthyism. Miller's play is a clearer, more cohesive drama. The play, commonly seen as a stand against oppression, has been reenacted countless times all over the world in both professional and amateur productions, and it went on to see a film version in 1996 starring Daniel Day-Lewis and Winona Ryder. Miller himself noted:

The Crucible [sic] is my most-produced play. It seems to be one of the few surviving shards of the so-called McCarthy period. And it is part of the play's history that, to people in so many parts of the world, its story seems to be their own. I used to think, half seriously, that you could tell when a dictator was about to take power, or had been overthrown, in a Latin American country, if The Crucible [sic] was suddenly being produced in that country. (Miller, "Are you Now or Were you Ever")

Part of what makes this play so popular and so adaptable, however, stems from Miller's less direct implication of McCarthyism in his portrayal of Salem. Indeed, while the published version of The Crucible contains extensive reflections by Miller on the similar nature of the accusers during Salem and McCarthy's reign, the play itself bears no clear markers of McCarthyism, instead remaining firmly rooted in Salem for its duration. 
The play tells the story of the John and Elizabeth Proctor ${ }^{20}$, both accused of witchcraft in Salem, and their main accuser, Abigail Williams. Miller gives absolutely no authenticity to the claims made by Abigail and the other accusers. By increasing Abigail's age to 17 (and therefore the age of sexual maturity) and claiming that she had an affair with John Proctor, Miller paves the way for accusations against Elizabeth, and eventually John, by a jealous Abigail who is clearly, at least in the eyes of the audience, faking her claims of witchcraft and persecution for her own advancement and revenge. Other accusers in the play are given different, although no less false and self-serving, motivations.

John and Elizabeth's attempts to remain true to themselves, each other, and their pride dominate Miller's drama. John eventually confesses his affair in an attempt to discredit the conniving Abigail; Elizabeth, who cannot impugn her husband in public despite her knowledge of the affair, refuses to confirm it before the judges, thus unwittingly condemning herself as a liar. Her actions will further condemn herself and her husband to death for witchcraft since their testimonies, proven false, cannot be trusted. Like Williams, Miller takes considerable creative license with the known history of Salem in order to align its intentions, its theatricality, its dishonesty, and its farce with similarly theatrical and farcical Red Scare and McCarthyism.

Miller's published text is prefaced by his "Note on the Historical Accuracy of This Play" which admits (in a somewhat contradictory fashion) that while there is "no one in the drama who did not play a similar — and in some cases exactly the same — role in history," and "the fate of each character is exactly that of his historical model," this is nonetheless "not

\footnotetext{
${ }^{20}$ Miller alters the spelling of the last name from "Procter" to "Proctor." This change appears intentional, perhaps meant to conjure images of the stoic attorney or clergyman, given that when he discusses the historical John Procter in his autobiography Timebends, he uses the proper spelling.
} 
history" (Miller, The Crucible 2). Because "little is known about most" of the people in Salem, the characters, despite Miller's preceding claims to accuracy, are "creations of my own" (Miller, The Crucible 2). Miller, like Williams, blurs the lines between the real and the created in order to simultaneously resemble and re-assemble the historical. Miller's text, however, can more easily be mistaken for history given its singular focus on Salem and its alleged reliance on the "historical model." Such a reliance gives Miller the chance to suggest more "truth" than fiction, a suggestion that has been challenged by multiple historians as problematic. $^{21}$

Into the Breach

Miller drops his audience, as did Williams, directly into the breach. Betty Parris is already showing signs of affliction and her father, Reverend Parris, is seeking answers. For the reader, there is additional context, found in nearly five pages of background that would not necessarily be made available to a performance audience (lest it was placed in the program). In these notes, Miller shows Reverend Parris no sympathy, noting, while he kneels over his daughter's sickbed, he "cut a villainous path" in history and "there is very little good to be said for him" (The Crucible 3). Parris, along with the others in Salem "believed, in short, that they held in their steady hands the candle that would light the world. We have inherited this belief, and it has helped and hurt us" (Miller, The Crucible 5). There is no forgiveness for Salem in Miller's contextual notes; thus, there is no forgiveness for the accusers of his own time. These breaches-in the $17^{\text {th }}$ and the $20^{\text {th }}$ centuries-have been brought upon us by our own actions.

\footnotetext{
${ }^{21}$ One of Miller's greatest critics, as mentioned earlier, is Chadwick Hansen, whose article, "The Metamorphosis of Tituba, or Why American Intellectuals Can't Tell an Indian witch from a Negro," attacks Miller's misuse of history, and the historians who subsequently mistook this fiction for reality in their own scholarship.
} 
Miller's views on Parris seem driven by Starkey's history rather than by the historical record (and Starkey's history it should be noted, takes some large liberties itself). For Starkey, Parris was a "rankling" minister, one who begrudgingly ruled in Salem, and who "had taken over the parish like a general taking over an army suspected of insubordination" (27). Miller intensifies this persona. When little Betty cannot be revived from a mute stupor after her father catches her dancing in the woods with her cousin Abigail, and their slave, Tituba, Parris demands that Abigail explain their actions. The fact that the girls were unsupervised, alone, at night, in the forest, and "dancing" with a slave automatically renders them guilty of multiple "sins"-from indiscretion and inappropriate eroticism (given their ages and marital status) to possibly witchcraft—in and against a rigid Puritanical society. Abigail begins what will be a play driven by unyielding confessions: "Uncle, we did dance; let you tell them I confessed it - and I'll be whipped if I must be. But they're speakin' of witchcraft. Betty's not witched" (Miller, The Crucible 9). Abigail's confession is not sufficient, however, as Parris seeks to prove that she is the "biggest sinner in the world" by searching the "foul waters of your [her] heart" until he is convinced that there is "none worse than" his niece (Bercovitch, Puritan Origins 15). He pushes her in the hopes that she will confess that they were dancing naked, that they were conjuring spirits, and that they were communing with the devil.

Parris also wants to know why Abigail has been fired from the household service of John and Elizabeth Proctor: "I have heard it said, and I tell you as I heard it, that she [Elizabeth Proctor] comes so rarely to church this year for she will not sit so close to something soiled. What signified that remark?" (Miller, The Crucible 11). Abigail rankles: “They want slaves, not such as I. Let them send to Barbados for that. I will not black my 
face for any of them"22 (Miller, The Crucible 11). Abigail's blackness, however, is not found on her face: 'the Devil's touch is heavier than sick. It's death, y'know, it's death drivin' into them, forked and hoofed" (Miller, The Crucible 13). It is this blackness, this death, that Parris tries, unsuccessfully to learn of and drive out of Salem via his niece.

\section{The Confessions}

Abigail's original denials of her uncle's claims quickly degenerate into a series of unrelenting confessions, both before the audience and among the assembled town members. Abigail meets John Proctor alone and hints at their affair, which she would like to continue. She speaks to her fellow forest-dancers and the audience is suddenly aware of not only her affair, but of the fact that there was naked dancing, spirits were conjured, and Abigail drank blood as a "charm to kill John Proctor's wife" in the hopes of replacing her (Miller, The Crucible 18). Thus, the audience learns that the breach has begun with Abigail and it is driven by her desire and lust.

Reverend John Hale, summoned as an expert on witchcraft and the workings of the devil, arrives to aid Parris and the townspeople in discerning what is afflicting their children. Pressed repeatedly to confess further wrongdoings in the forest, Abigail turns instead against Tituba, saying she forced Abigail to drink blood. Tituba originally denies Abigail's claims, but the truth does not appease those questioning. Parris threatens: "You will confess yourself or I will take you out and whip you to death, Tituba!” (Miller, The Crucible 42). An

\footnotetext{
${ }^{22}$ Miller is referencing Tituba, Parris' slave, with this use of "Barbados" and "black," a point critics, including Hansen, find great fault with given Tituba's likely Indian heritage. Miller's conversion of Tituba from a Caribbean Indian to a "Negro slave," Hansen argues, is done for shorthand and convenience and because of prejudice: "it is painfully evident that we are dealing here with a kind of inverse racial prejudice, and that where witches are concerned, American intellectuals prefer Indian to English; and half-Indian, half-Negro to Indian; and Negro to half-Indian, half-Negro" (11).
} 
observer joins in the fray, before Tituba can even respond to Parris, screaming, "This woman must be hanged! She must be taken and hanged!" (Miller, The Crucible 42). Tituba clearly sees her limited options unfolding before her and admits that she has seen the devil and he has bid her to kill Parris. She also "confesses," at the bidding of those who have just threatened to kill her, to having seen four people walking with the devil. Before she can name more than two, Abigail, and a suddenly alert Betty, begin naming names as well, convincing the town that witchcraft is upon them and only confession will free those afflicted. A breach begun by desire and a town's suspicions quickly becomes a crisis that spreads, as Miller paints it, like a disease over the town.

Acts two and three contain additional confessions as the young girls found dancing in the woods begin receiving visions, attacks, and are "touched" by those who can allegedly send their spirits out through witchcraft. As the girls name more and more "witches," many townspeople choose to "confess" their crimes, most likely in order to avoid being hanged. John Proctor's wife, Elizabeth, is named, and John calls forth his hired help, Mary Warren to confess that the evidence used against Elizabeth, a poppet, and Abigail's own "infliction," allegedly received at the bidding of Elizabeth, are fabricated. Indeed, Mary Warren made the poppet for Elizabeth herself, likely as a means, Miller suggests, of setting her up to hang. Mary Warren originally confesses to the judges that she "never saw Satan; nor any spirit, vague or clear, that Satan may have sent to hurt her. And she declares her friends are lying now" (Miller, The Crucible 92). When Abigail vehemently denies lying, John Proctor confesses to adultery with Abigail to convince the judges of her motives for attempting to destroy his wife. As she did in real life, Mary Warren then changes her story when her friends turn on her and begin accusing her of witchcraft. Recanting her previous recanting, 
she turns again against her employers, the Proctors. Miller highlights the insanity of the need to name names in order to save oneself. As John Proctor pleads with Mary Warren to tell the truth, she screams at him, "I'll not hang with you!" (110). While the judges assume she is turning against the devil, the audience knows that she is instead simply saving her life, turning on Proctor as to take the scrutiny off herself. There is no holy mission here; there are no excuses for damning another to save oneself. Driven by fear, desire, anger, and profit, these accusers (and condemners) are, Miller suggests, beyond redemption.

Hysteria builds as the confessions mount. John Proctor attempts to persuade John Hale that those who confess do nothing to improve society: "And why not [confess], if they must hang for denyin' it? There are them that will swear to anything before they'll hang; have you never thought of that?" (Miller, The Crucible 65). Like Williams, Miller spends significant time focusing on the trials as a way of demonstrating the crisis and exploring the redressive means that cannot, ultimately, be sufficient or even just. Like Williams, his own means of redress - the drama — serve to highlight the failures of those that have come before (the trials at Salem) and thus those that are occurring at the time (the hearings of the HUAC/McCarthyism).

Indeed, if Salem Village were as spiritually sick as its confessions suggest, and God used "a father's rod...to improve the errant child," then God would need to spend a significant amount of time "reforming" Salem after Miller's second and third acts (Bercovitch, The American Jeremiad 8). By piling confession upon confession, Miller may be demonstrating the role of hysteria and pressure, but he is also making the confession absurd. He belittles the role of confession in Puritan American—and 1950s America-by overloading the reader with a melee of true and false confessions - each detrimental and 
destructive in its own way. As Bercovitch notes, "Crisis was the social norm" for Puritanical America; Miller's portrayal of that continual crisis reveals his condemnation of hyper-active social and personal consciousness (The American Jeremiad 23).

Miller's insistence on the act of confession, while rendering the act absurd for the viewer who sees the moments occurring back-to-back, is also somewhat consistent with the historical record. While the trials themselves happened over many months rather than the few short hours of a play, there were approximately 50 confessions of witchcraft in Salem (Reis 12). Elizabeth Reis attributes this large number in part to the connection between confession and "self-preservation," but she also notes that women in particular were likely to "interpret their own sin, no matter how ordinary, as a tacit covenant with Satan" (12). Men, according to Reis, were far more likely to "focus on particular sins like drinking and gambling" and thus they, unlike their female counterparts, "seemed confident of their ability to throw off their evil ways and turn to God in time" (12). Oddly enough, Millers' assigning of the role of adulterer to John Proctor - a fact certainly not found in the historical recordmakes Proctor more feminized using Reis's analysis. He admits his sin because he thinks himself a sinner (and because he wishes to implicate an also guilty Abigail). Elizabeth's pride keeps her more closely aligned with the masculine. Hysterical society, in Miller's view, turns on its head, disrupting all possible order. Indeed, ironically, in a town obsessed with sin and confession, the judges ignore the one true sin — the adultery—and see it as little more than a desperate lie. Gender reversal, blindness to truth, and sin abound in a populace awash in its own failings.

If Miller can be seen as challenging Puritanical theories of sin and redemption-as "purification" does not seem possible and confession leads not to reformation but rather to 
deformation — he can also be seen as affirming Foucault's theories concerning the role of confession and punishment in society. In speaking of the historical move of many societies toward emphasizing confession and listing the reasons for such a shift, Foucault writes:

...the confession constituted so strong a proof that there as scarcely any need to add others, or to enter the difficult and dubious combinatory of clues; the confession, provided it was obtained in the correct manner, almost discharged the prosecution of the obligation to provide further evidence (in any case, the most difficult evidence). Secondly, the only way that this procedure might use all its unequivocal authority, and become a real victory over the accused, the only way in which the truth might exert all its power, was for the criminal to accept responsibility for his own crime and himself sign what had been skilfully [sic] and obscurely constructed by the preliminary investigation. 'It is not enough,' as Ayrault [...] remarked, 'that wrong-doers be justly punished. They must if possible judge and condemn themselves.' (Foucault 37-38)

Confession, then, in the Salem witch trials and the witch-hunts of the 1950s, released the judges, investigators, Senators, and society from the burden of proof. But it also served a distinct social purpose. As Bercovitch notes, New England was on an errand from God, but "The very concept of errand, after all, implied a state of unfulfillment" (original emphasis; The American Jeremiad 23). To have any real hope of fulfillment, Salem needed the witches to confess and thus reaffirm both the legal structure of the society as well as the Godly mission of the community itself.

Miller exploits such a view of confession. As The Crucible nears its close, John Proctor tries to confess in order to save his life. He initially balks when he realizes his confession must be written down by an observer "for the good instruction of the village, Mister; this we shall post upon the church door!" (Miller, The Crucible 128). Still, Proctor admits to having seen the Devil who bid him "to do his work upon the earth" (Miller, The Crucible 129). Indeed, Proctor's guilt from his extramarital affair can be seen as sufficient fuel for these confessions. They are not enough, however, for a righteous town. Proctor is 
repeatedly asked to name others, but he cannot: “'I speak my own sins; I cannot judge another.' Crying out, with hatred: 'I have no tongue for it'” (Miller, The Crucible 131). Still, the magistrates are enticed by his confession; the breaking of such a man and the publication of his fall is tempting. Proctor signs his confession under much personal duress, but he will not hand it back to the magistrates: "Because it is my name! Because I cannot have another in my life! Because I lie and sign myself to lies! Because I am not worth the dust on the feet of them that hang! How may I live without my name? I have given you my soul; leave me my name!” (Miller, The Crucible 133). Proctor becomes Miller's tragic hero because he chooses death over disgrace. He cannot, in the end, sacrifice truth for his own life. Unlike those who sacrificed others for their own survival—whether literal or economic-Miller's John Proctor will die. And while one of the judges cannot believe he chooses his name and self-respect over his life, begging Elizabeth to "Go to him, take his shame away!" while demanding "What profit him to bleed?," Elizabeth knows that "He have his goodness now," and that "goodness" trumps all for the Proctors, and, presumably, for Miller (Miller, The Crucible 134).

Meaning in the Madness

Miller's own views on the McCarthy era are made clear by Proctor and his refusals: "In effect, it came down to a governmental decree of moral guilt that could easily be made to disappear by ritual speech: intoning names of fellow sinners and recanting earlier beliefs" (Miller, Timebends 331). Miller's Proctor is undeniably guilty, just not of the sins of which he is accused. Miller equates this guilt to the underlying guilt and fear that allowed McCarthyism to take hold: "Without guilt the 1950s Red-hunt could never have generated such power. Once it was conceded that absolutely any idea remotely similar to a Marxist 
position was not only politically but morally illicit, the liberal, with his customary adaptations of Marxist theory and attitudes, was effectively paralyzed" (Miller, Timebends 341). Proctor's misplaced guilt is linked to the liberal's paralysis before the charging bull of the HUAC and McCarthy. And, as Miller tries to imply, no one escapes these scenes unchanged. Those persecuted are certainly altered, but the true destruction appears to be wrought on the society whose fear drives, and allows, the proceedings. Miller recalls Girard, who states that "Scandal is always contagious; those who are scandalized are likely to communicate their desire to you, or, in other words, drag you along their same path so that they [...] scandalize you" (The Scapegoat 172). As The Crucible illustrates, in a town where so many are ill, contagion spreads like wildfire.

What Miller attempts to carefully craft in The Crucible is a sense of bitter irony. Salem, like 1950s America, instead of reaffirming a mission of righteousness through violence and accusations, invalidated any hopes of such a reaffirmation through its hysteria and viciousness. Thus John Proctor, the moment after seeing Abigail convince the judges of not only Elizabeth's guilt as a witch but also his own guilt as a conspirator against Salem, cries out, "I say—I say—God is dead!" (111). While such a statement only increases John Proctor's position as a heretic and a damned man, his proclamation is likely meant to emphasize that the godliness of Salem—and its alleged holy mission—is what has died.

Of course, Miller places these words in Proctor's mouth, as they are not reflected in the historical record. Unlike Williams, and despite his own claims to historical accuracy, Miller changes the timeline of Salem, the words of Salem, and even some of the main characters of Salem. But he integrates enough of Salem to maintain the liminality, the overlap of past and present. The Proctors, Abigail, and Reverend Parris feature prominently 
(albeit with newly generated back stories). Occasionally, Miller employs the actual language of the accused in his play. He takes the intent of the characters and magnifies it for the stage. A defiant John Proctor becomes nearly heroic in The Crucible. The calculating Abigail of Salem becomes the driven whore of The Crucible. The viewer/reader can see enough similarities to connect this play to the past, and to connect this past to a McCarthy-era present, also driven by fear, confession, and suspicion.

Williams and Miller use the Salem Witch Trials as the means to expose an ongoing crisis in the United States. The inherent belief in the mighty errand of this chosen country has repeatedly led, despite a professed love of human rights and democracy, to a desire to patrol and limit the thoughts and desires of its populous. Both Williams and Miller use confession as a way of demonstrating how this desire is destructive. For Williams, the confession is battered, unable to carry the weight of the desire. For Miller, the confession is absurd, based on lies and fear. Using theater itself as a means of redress, Miller and Williams seek to expose the crisis and the repeated failings of our "trials" and "witch-hunts." History has proven Williams and Miller correct: the uneasy resolution achieved following Salem and the HUAC/McCarthy era has left behind a still bifurcated nation and an underlying fear of anti-American otherness. Without fully returning to crisis-without deconstructing our fears in order to re-member our past, perhaps the wound left behind will never truly heal. 
CHAPTER 2: Confrontation and Challenge: Baldwin's Blues for Mister Charlie as Response to the Murder of Emmett Till ${ }^{23}$

Like Williams and Miller before him, James Baldwin reacted to a historical precedent by writing a play that called into question our understanding of history, our understanding of our nation, and our understanding of ourselves. Retelling the murder of Emmett Till and inspired by the murders of Till and Medgar Evers, Baldwin uses his 1964 play Blues for Mister Charlie as a means of situating the reader/viewer in "Plaguetown, U.S.A.," where race relations are synonymous with brutality and inhumanity. ${ }^{24}$ And yet, even within this plague-

\footnotetext{
${ }^{23}$ Although altered in many respects, much of this chapter is based upon (with permission of the publisher) my book chapter, "No Blues for Mister Henry: Locating Richard's Revolution," published in Reading Contemporary African American Drama: Fragments of History, Fragments of Self (2007).

${ }^{24}$ Baldwin explicitly defines this plague in his notes for the play, stating: "The plague is race, the plague is our concept of Christianity: and this raging plague has the power to destroy every human relationship" (Baldwin, "Notes for Blues" xv). Baldwin again made a correlation between race (or more specifically, race relations) and plague in his 1965 debate with William F. Buckley at Cambridge University. In discussing Alabama Sheriff James Gardner Clark, Jr., who violently arrested and beat those participating in peaceful protests for civil rights, Baldwin notes, "Something awful must have happened to a human being to be able to put a cattle prod against a woman's breasts. What happens to the woman is ghastly. What happens to the man who does it is in some ways much, much worse. Their moral lives have been destroyed by the plague called color" (Warner). In many ways, Baldwin's use of the term "plague" is reminiscent of Albert Camus' The Plague, in which an unknown disease ravages the town:
}

...the plague had swallowed up everything and everyone. No longer were there individual destinies; only a collective destiny, made of plague and the emotions shared by all. Strongest of these emotions was the sense of exile and of deprivation, with all the cross-currents of revolt and fear set up by these. (Camus 149)

One member of the town views the physical plague as a metaphor for the perpetuation of violence and capital punishment carried out for the benefit of the society: "I only know that 
ridden setting, Baldwin sees the possibility for change. He writes a fictional murder to reflect actual murders in the hopes of someday being able to tell a different story: "We are walking in terrible darkness here, and this is one man's attempt to bear witness to the reality and the power of light" (Baldwin, "Notes for Blues" xv). Such light, for Baldwin, is to be found in the reactions to such murders. At the close of his play, his surviving charactersand hopefully his audience - prepare to stand and fight for justice and equality.

\section{Defining the Social Drama of the Historical Precedent}

Emmett Till

A synopsis of the 1955 murder of 14-year old Emmett Till, one of the main inspirations for Baldwin's Blues, opens this project's introduction. Sent, along with his cousin, to spend the summer in Money, Mississippi with his mother's family, Emmett Till was unfamiliar with the ways of the South, having been born and raised in Chicago. On August 24, he and his cousin took their great-uncle's car into town and stopped to buy some candy. Some suggest that Till stopped outside the local store and "pulled out some pictures of his white friends in Chicago and showed them to some of the local boys" (Orr-Klopfer 12). Others suggest that he "bragged of his white girlfriend in Chicago" (Houck and Grindy $13)$.

Regardless, it was what happened inside the store that sealed Till's fate. Allegedly dared by the local boys to speak to Carolyn Bryant, the store-owner's wife, Till went inside, bought some candy, and "might have said, 'Bye, baby' before he whistled at Carolyn Bryant"

one must do what one can to cease being plague-stricken, and that's the only way in which we can hope for some peace or, failing that, a decent death" (Camus 223). For Camus's narrator, as for Baldwin, this plague is the physical manifestation of a greater deficiency: "...each of us has the plague within him; no one, no one on earth, is free from it" (Camus 224). 
(Orr-Klopfer 13). Carolyn Bryant alleged Till "grabbed her at the waist and asked her for a date" and "used 'unprintable' words" when speaking to her (Orr-Klopfer 13). Other young men in the store alleged Till was asked to leave the premises for "being 'rowdy"" (OrrKlopfer 13).

The next evening, around 2:30AM, Till was removed from his great-uncle's home at gunpoint by Roy Bryant (Carolyn's husband), and his half-brother. Till's body was found by a fisherman in the Tallahatchie River, 12 miles north of Money (Orr-Klopfer 15). Till had been "stripped naked, pistol-whipped, and shot through the head with a .45-caliber Colt automatic" before being "barb wired to a seventy-four pound cotton gin fan" and dropped in the river (Orr-Klopfer 16, 15). The murderers may well have used the old cotton gin fan because it was readily available, but it is certainly not without historical weight in and of itself. Calling forth cotton, the crop that increased the need for slavery in the South, the fan represented more than simply a stray piece of machinery. Indeed, the ongoing, massive inequality introduced by slavery allowed both for the murder of Till and the mindless dumping of his body; both the boy and fan were seen as disposable. The mutilation of Till's body — both at the hands of his murderers and due to the ravages of the river-left the boy virtually unidentifiable. Nonetheless, Till's mother, Mamie, had an open casket at his funeral as she "wanted the world to see what they did to my baby" ("Emmett Till's casket"). And see they did: "Over 100,000 people walked by Till's open casket before the funeral" (OrrKlopfer 18). Thousands more saw the photographs that were published in Jet, The Crisis, the Chicago Defender, the Pittsburgh Courier, the New York Amsterdam News, and other publications (Houck and Grindy 31). The photographs did not appear, however, "in a single predominantly white newspaper" (Houck and Grindy 31). 
Bryant and his half-brother alleged that they picked Till up to teach him a lesson, but released him, alive, the same evening and never saw him again. The men were arrested and the trial was well attended, by both blacks and whites, including daily attendance by Mamie Till, and journalists from all around the world. Nonetheless, blacks, even Detroit Congressman Charles Diggs, were forced to sit at the "Jim Crow' table," nothing more than a "card table off to the side," set up by the local sheriff (Orr-Klopfer 29). Till's murder, and the subsequent reaction that would become one of the harbingers of the Civil Rights Movement, was a clear and decisive breach in the Money, Mississippi community and throughout the United States. As indicated in the microcosm of the racially divided courtroom, it instigated a swift taking of sides, and those sides, with certain exceptions, fell along clear racial lines. ${ }^{25}$

The white jury returned a "not guilty" verdict after a 67-minute deliberation (Fox). The court, a medium that ideally should have been a form of redress ultimately leading to a return to peace, instead further deepened the breach and surrounding crisis. One foreman alleged, "I feel the state failed to prove the identity of the body," a difficulty derived from the extreme damage Till sustained, both by the assailants and the time spent underwater ${ }^{26}$ (qtd. in Orr-Klopfer 32). Another juror was perhaps more honest: “We wouldn't have taken so long

\footnotetext{
${ }^{25}$ Mississippi-born William Faulkner was one well-known white American who responded vehemently to the Till murder. His newspaper editorial hit the front page of the Jackson Daily News and included the following remark: "If we in America have reached that point in our desperate culture when we must murder children, no matter for what reason or what color, we don't deserve to survive and probaly [sic] won't" (qtd. in Houck and Grindy 57). Baldwin uses the character of Parnell in his play to illustrate the difficulties of white supporters, however, both in terms of the personal sacrifices required for whites and the distrust and distance experienced by blacks.

${ }^{26}$ A 2005 autopsy would confirm that the body was Till's; see footnote number 29 on page 76.
} 
if we hadn't stopped to drink pop" (qtd. in Orr-Klopfer 32). A mere two months post-trial, Bryant and his half-brother famously confessed their crime to an author writing about the murder, but as they had already been tried and found not guilty, they could not be retried without double jeopardy. Lynching

The wife of murdered civil rights leader Medgar Evers ${ }^{27}$, Myrlie Evers, spoke of the impact of the Till murder and the failings of "justice":

...it was proof that even youth was no defense against the ultimate terror, that lynching was still the final means by which white supremacy would be upheld, that whites could still murder Negroes with impunity, and that the upper- and middle-class people of the state would uphold such killings through their police and newspapers and courts of law. (qtd. in Orr-Klopfer 45)

Lynching was not a new phenomenon to be feared, of course. A 1933 study claims that there were 3,724 reported lynchings in the United States from 1889-1930, and over four-fifths of those victims were African-American (with many of the remaining victims also classified as minorities, including Native Americans) (Raper 1). A second study reports that there were 4,697 reported lynchings between 1880 and 1930, but "the actual number is almost surely higher" as lynchings were not generally reported — or recorded — as a crime (Apel and Smith 15). Lynchings occurred "primarily in the South" and most lynched victims were African American men (Apel and Smith 15). As Trudier Harris notes, this phenomenon was reflected in the literature of the time: "African American literary works from the mid-nineteenth century to the mid-twentieth century depict mutilated, castrated, shot, burned, and hanged black male bodies—with an occasional female sharing that dreadful fate" (Harris 5).

\footnotetext{
${ }^{27}$ Medgar Evers was a second source of inspiration for Baldwin's Blues for Mister Charlie. Baldwin dedicates the published play "To the memory of Medgar Evars [sic], and his widow and children, and to the memory of the dead children of Birmingham."
} 
Lynching was commonly "justified" because it "protected" the Southern white

woman from rape at the hands of the black man, a "threat" that was very much behind the

Emmett Till murder:

Regardless of the cause of a particular lynching, there were always those who defended it by the insistence that unless Negroes were lynched, no white woman would be safe, this despite the fact that only one-sixth of the persons lynched in the last thirty years were even accused of rape. Regardless of the accusation, an example must be made of the accused Negro for the sake of womanhood. (Raper 20) ${ }^{28}$

Even in the murder of 14-year old Till, the "duty" to protect white womanhood (and white male pride) can be found at the heart of the breach.

Trudier Harris argues that it is the need to define and protect white manhood, and not white womanhood, that ultimately leads to the lynching of black men, and she explores this thesis via Baldwin's works:

Lynching black men but desiring the very sexuality that has presumably led to the lynching, Baldwin posits, is the natural position of white men in the South and the reason for black men to be fearful of the South. Indeed, it is almost impossible in a Baldwin work to be a black man in the South. The two states are irrevocably oppositional. (22)

Whether white men feared or desired black male sexuality (or both), they ultimately sought

to extinguish it, even in boys as young as Emmett Till.

${ }^{28}$ Onwuchekwa Jemie was much less forgiving in the portrayal of white womanhood and the fear of rape: "When a white woman invites you to love, you are doomed. If you accept and it is found out, as it will sooner or later, she will cry rape, and you will be lynched. If you refuse, she will in humiliation and revenge cry rape, and you will be lynched" (145).

Langston Hughes used poetry to highlight and denounce the fragility of the white woman; in "Silhouette" Hughes instructs the "Southern gentle lady / Do not swoon" for they have "just hung a black man / In the dark of the moon" in order to show "How Dixie protects / Its white womanhood" (Hughes, "Silhouette" 305-306). Hughes admonishes the white woman for her implicit (and/or explicit) involvement in the lynching by concluding the poem: "Southern gentle lady, / Be good! / Be good!" (Hughes, "Silhouette" 306). Additionally, scholars have noted that white women were certainly not so fragile as to not attend - and be photographed at - the lynchings of black men, as evidenced in texts such as Without Sanctuary: Lynching Photography in America and Lynching Photographs. 


\section{Redress?}

Less than 10 years after the murder of Till, Baldwin would produce and publish

Blues. Baldwin highlights not only the breach, but also the subsequent — and unending-lack of effectual redress and resolution. For it is clear that the Civil Rights Movement, ignited partially by the Till murder and trial, would only continue to challenge American unity and the very concepts of American democracy and equality for many years to come. Baldwin asserts:

There's a dead boy in my play, it really pivots on a dead boy. The whole action of the play is involved with an effort to discover how this death came about and who really, apart from the man who physically did the deed, was responsible for it. The action of the play involves the terrible discovery that no one was innocent of it, neither black nor white. All had a hand in it, as we all do. But this boy is all the ruined children that I have watched all my life being destroyed on streets up and down this nation, being destroyed as we sit here, and being destroyed in silence. This boy is, somehow, my subject, my torment, too. And I think he must also be yours. ("Words of a Native Son" 712)

Blues, then, is one redressive means among many, searching for an answer and searching for reasons. But it is also a call to action - a re-opening of the festering wound, and a demand for the fight to continue. Baldwin certainly did not expect his play to be the final redressive means, the moment that would revolutionize the Movement, but he did expect to keep it moving forward, seeking additional redress, and hopefully, someday, resolution.

Ultimately, Blues has been one of many ongoing attempts at redress for this particular breach. In their introduction to Emmett Till and the Mississippi Press, Davis W. Houck and Matthew A. Grindy recount some of the many ways in which contemporary America has tried to reconcile the murder of Emmett Till:

Beginning with the television documentary Eyes on the Prize and Stephen J. Whitfield's book $A$ Death in the Delta, scholars, playwrights, poets, songwriters, filmmakers - even Hollywood producers - remain riveted by it 
[the murder]. Ebay customers can even buy Emmett Till '55' Jerseys. An advanced Google search on 'Emmett Till' reveals 308,000 hits as of January 2007. (5)

The interviews and research conducted for a second documentary, The Untold Story of Emmett Louis Till, drove the Department of Justice and FBI to reopen the case in 2004. While the main perpetrators were dead, the documentary raised the possibility of living witnesses and contributors, including Carolyn Bryant. Although no additional arrests were $\operatorname{made}^{29}$, the continued, active search for resolution indicates that this breach is still very much present in the American mind.

Indeed, Till's memory has been seemingly ubiquitous in 2013. In the spring, African American rapper L'il Wayne received significant media attention when the lyrics to his new song, "Karate Chop," became public. In the song, the rapper describes a violent sexual encounter with a woman, noting he is going to "Beat that pussy up like Emmett Till" ("Future-Karate Chop"). L'il Wayne would eventually assert that the lyrics were leaked and never meant to go public, but the damage was done. The Till family issued a statement denouncing the lyrics, Pepsi (Mountain Dew) dropped the singer as a spokesperson, the record company issued a public apology, and L'il Wayne apologized to the Till family in concert ("Future-Karate Chop").

${ }^{29}$ Till's body was exhumed in 2005 and an autopsy put to rest a long-standing rumor that it was not Till himself who was buried (a rumor begun, in large part, by the defense who tried to allege that the body taken from the river was not identifiable and therefore no one could be tried for Till's murder) (Orr-Klopfer 62). The autopsy also showed that Till died of a "gunshot wound to the head and that he had broken wrist bones and skull and leg fractures" ("FBI releases Emmett Till autopsy"). The FBI ultimately could not gather enough new evidence to bring charges against new defendants (mainly Carolyn Bryant Donham, who many felt was active in the murder of Till). The FBI released the case to local prosecutors, but a "Mississippi grand jury ruled [...] that there was insufficient evidence to indict her, essentially closing the book on the case" ("FBI releases Emmett Till autopsy"). 
During the summer of 2013, celebrity chef Paula Deen was accused of using racial slurs and in the midst of her public downfall, many angered former fans took to one of her Twitter sites, normally reserved for recipe posts, and began entering phony names of dishes and linking them to her site, using her feed's hashtag (“\#PaulasBestDishes”). One contributor's suggestions included a reference to Till: "Django Djelloshots? Emmitt [sic] Tillapia? Malcolm Xtra Hot Wings..." (R. Brandon). Finally, following the July acquittal of George Zimmerman in the murder of Trayvon Martin, many public figures, including Oprah Winfrey, linked the killings of the two young men. Indeed, a Facebook meme circulated in which pictures of the two young men were placed side by side with the text "No justice in 1955" at the top and "No justice in 2013?" at the bottom. While all of these references are problematic in their own ways, they demonstrate that Till remains active in the collective American memory and, as best evidenced in the parallels drawn to Trayvon Martin, they indicate that redress remains elusive and the breach is far from over.

\section{Blues for Mister Charlie}

\section{Play Summary and Production History}

Before L'il Wayne, Paula Deen, and Trayvon Martin, however, James Baldwin was struggling with how to make sense of the Till murder. Baldwin's Blues tells the story of Richard Henry, son of a Southern preacher, who returns to the South after years of living in the North. Unable and unwilling to conform to the behavior expected of an African American man in the South before the attainment of Civil Rights, Richard encounters—or, as some critics have argued, creates - difficulties with the white townspeople in his hometown, especially Lyle Britten. Lyle has been rumored to have killed African Americans in the past, and, indeed, since much of the play is told out of chronological order, the audience sees Lyle 
murder Richard in the opening moments. What the audience is left to recreate, then, is why Richard is murdered.

The play centers primarily on Richard's search for truth—regarding himself, his family, and his assigned place in society. Baldwin acknowledges in his introduction to the play that Richard Henry is an adult revision of Emmett Till. It is perhaps unsurprising, then, that when Richard is unable to reconcile societal expectations and his own sense of selfworth, his downfall occurs in the local general store owned by Lyle and managed by his wife. Going well beyond whistling, Richard flaunts his money, insults Lyle, and aims sexually explicit comments at Lyle's wife. The audience is forced to watch Richard's murder a second time, followed by the farce of a hearing that allows Lyle— just like Till's murderersto go free.

Like Miller and Williams, Baldwin alters significant facts of the known history in order to support and extend his condemnation of the murder. Baldwin does more than simply alter or add characters, however; he completely rewrites Emmett Till in the form of Richard Henry. And while he cannot save him, he endows Richard with the strength, audacity, and anger to confront and challenge his accusers. He does not simply ask the viewers/readers to consider his point of view—he leaves them no choice. This play's strength is its force: its refusal to accept that what has come before is all that can be and its demand that the audience see truth in all its barbarity. Through that barbarity, oddly enough, Baldwin seems to suggest that even in Till's/Henry's murder, there is a moment for hope if we see, and pursue, understanding and change. And for Baldwin, there is no room for dishonesty, half-truths, meekness, or comfort in this search for change. Instead, he argues that by working together, all Americans can make progress: 
We can do something which has not been done in the history of the world before. The terms of our revolution, the American Revolution, the terms of these, not that I drive you out or that you drive me out, but that we come together and embrace and learn to live together. That is the only way that we can have achieved the American Revolution. Now if we can face this, and it involves facing a great many things, it demands that white people face the fact that I, for example, or any black person they will ever meet or have ever met, I'm not an exotic rarity. I am not a stranger. I'm none of those things. On the contrary, for all you know, for all you know, I might be your uncle, your brother, your cousin, among other things. (Baldwin, "You cannot negotiate")

For Baldwin, then, Blues is a reckoning and a recognition. It is history reborn, but it is also history repurposed. There is no looking away, there is only looking forward, and such a glance is meant to be painful for all in the hopes of eventual growth.

The original production ran for 150 performances in 1963-1964. The play almost closed much earlier due to poor ticket sales and subsequent financial losses, but it was extended due in part to large donations (including those from the Rockefeller family) and cost-saving methods. Additional relief came from the Actors Studio, "from the waiver of royalties by various parties, including the lowering of rent by the City Playhouse, and from outside contributions" (“"Blues for Mister Charlie' Closes" 16). Nonetheless, the Actors Studio and others viewed the production as a "victory, not a defeat" as "We succeeded in presenting an important play with an important statement to make it a crucial point in the history of civil rights" (Crawford qtd. in “"Blues for Mister Charlie' Closes” 16). The play also attracted a large African American and union audience, changing the traditional (white) theater audience. ${ }^{30}$

${ }^{30}$ In order to attract non-traditional audience members, the ticket price was lowered. Even still, the lowered ticket price was too high for many who wished to attend: "There were often nights when our balconies were full but our orchestra was almost empty. In our 17 weeks run, there were only four weeks when enough people came to the theatre to make the boxoffice [sic] break even” (“"Blues for Mister Charlie' Closes” 16). 


\section{(Very) Critical Reception}

Nonetheless, Blues has not fared well with critics - then or now — and the play is not considered one of Baldwin's strongest pieces. In 1967, Loften Mitchell offered a relatively kind condemnation of the play and of Richard in Black Drama, stating: "The playwright took great pains not to romanticize his black characters nor his white ones-sometimes too much. His leading character is hardly idealized" (L. Mitchell 201). Tom F. Driver, one of the play's biggest supporters and author of "The Review That Was Too True to Be Published" (1964), further explained the "hardly idealized" Richard, calling him "A Negro youth" who was "rebellious and unstable to the point of courting death" (Driver 292). Calvin C. Hernton (1970) notes that reviewers in the Village Voice were "saying that Richard got lynched because he 'asked for it"” (Hernton 111), a point John Simon (1975), supports: "Richard taunts Lyle and his dim, mousy wife, Jo, to the point where Lyle kills him” (Simon 48).

Time has not improved much for Baldwin's Blues, or Richard Henry. As scholar Nicholas K. Davis notes in his article "Go Tell It On the Stage: Blues for Mister Charlie as Dialectical Drama" (2005), "The most distant reverberations are the continued omissions of Blues from such recent and important revisionist studies as Dwight McBride's James Baldwin Now and D. Quentin Miller's Re-Visiting James Baldwin: Things Not Seen, which cite the play only once apiece, both times in passing ${ }^{31 "}$ (N. Davis $\left.31-32\right)$. Trudier Harris does write about Blues and Richard Henry in a chapter of The Scary Mason-Dixon Line (2009), but she argues that Henry "knowingly commits suicide, for a black man cannot claim

\footnotetext{
${ }^{31}$ See Dwight McBride, ed. James Baldwin Now. New York: NYU Press, 1999 and D. Quentin Miller, ed. Re-Visiting James Baldwin: Things Not Seen. Philadelphia, Temple University Press, 2000.
} 
manhood on southern territory, from Baldwin's perspective, and live to tell the tale",32 (23). Koritha Mitchell is one of the few critics who finds more redemption in Baldwin's Richard Henry (although we disagree, as she notes, on other readings of Blues, to be discussed later in this chapter):

Many critics have suggested that Blues for Mister Charlie lacks dramatic suspense because Richard's body is dumped at the beginning of the play. This assumes that his being killed by a racist is all that matters. Might Baldwin be interested in giving voice to what Richard meant to his community or what the community meant to Richard? (55)

And yet, these questions remain unanswered by most critics who instead choose to ignore Blues or to dismiss it.

What is it about Richard that is so aggravating, so polarizing? Carolyn Wedin Sylvander, author of James Baldwin (1980), discusses Richard's "inability to adjust to the racial realities of the Southern town of his birth" by arguing "He is not humble, soft-spoken, or discreet, and he inevitably gets into trouble with Lyle Britten and his wife, Jo, who are representative of white townspeople who can't imagine what has gone wrong with all the 'good niggers' they grew up with” (Sylvander 99). Lyle Britten supports Sylvander's evaluation, saying Richard "might as well have been a northern nigger. Went North and got ruined and come back here to make trouble - and they tell me he was a dope fiend, too" (Baldwin, Blues 13). Richard defines, exacerbates, and embraces the flippancy originally (and fatally) attributed to Emmett Till. He seems to make the viewers, readers, and critics uncomfortable because he tests the boundaries knowing the result; Baldwin reminds us, however, that those boundaries are unjust and need to be tested.

\footnotetext{
${ }^{32}$ Harris's footnote on this sentence acknowledges our respectful disagreement on Baldwin's intention and the characterization of Henry: "Meredith M. Malburne argues that Richard is much more important in death than in life, though she does not subscribe to the suicide theory" (Harris 209).
} 


\section{Rereading Richard}

Richard's friends and family present him entirely differently than many in the town and many critics; they present him as both spiritual and spirited. He is remembered at the opening through two songs - the hymn "His Eye is on the Sparrow" and the blues song "Midnight Special" (Baldwin, Blues 16-17). He quickly becomes rooted, therefore, in the black church and the black blues tradition: the reader is readily aware of his connections to the Southern community.

Such connections are reinforced through the presence of Richard's father, Reverend Meridian Henry, and his grandmother, Mother Henry. The viewer/reader meets both characters before s/he meets a living Richard. Both Meridian and Mother Henry begin the play by representing the "simple," "warm-hearted and good natured" blacks the town expects (Baldwin, Blues 49). Even after the murder of his only son, Meridian addresses Richard's friends, just back from a protest, warning them "We can't afford to become too distrustful" (Baldwin, Blues 6). Mother Henry offers a similar turn-the-other-cheek mentality when speaking of the white townspeople: "I used to hate them, too, son. But I don't hate them no more. They too pitiful" (Baldwin, Blues 16). While the white characters tend to see Richard as defiant, then, his family and friends - all black — often present him as someone more multi-dimensional. Perhaps projections of themselves, Richard becomes, in these initial presentations, a somewhat similar mix of spirituality and moral superiority.

Richard is not quite the character either side presents, however. Indeed, Richard's first appearance is all the more shocking considering his family and his friends who, despite angry talk among themselves, seem to remain peaceful protesters. Richard, driven home from New York after losing his chance at fame and fortune to a drug addiction, tells Mother 
Henry he "can't get over" having to return to the "ass-hole of the world, the deep, black, funky South" where he is surrounded by "all these nowhere people" (Baldwin, Blues 17-18). His first appearance is angry and frustrated as he insults his family and his surroundings. He is disrespectful to his grandmother and father, telling the former, "It's easy for you to talk, Grandmama, you don't know nothing about New York City," and speaking of the latter: "I didn't want to come back here like a whipped dog. One whipped dog running to another whipped dog. No, I didn't want that. I wanted to make my Daddy proud of me—-because, the day I left here, I sure as hell wasn't proud of him" (Baldwin, Blues 18, 20). Convinced that whites murdered his mother while his father did nothing to avenge her death, Richard tells his grandmother:

I'm going to treat everyone of them [whites] as though they were responsible for all the crimes that ever happened in the history of the world —oh, yes! They're responsible for all the misery I've ever seen, and that's good enough for me. It's because my Daddy's got no power that my Mama's dead. And he ain't got no power because he's black. And the only way the black man's going to get any power is to drive all the white men into the sea. (original emphasis; Baldwin, Blues 21)

Shortly after his tirade, Richard shows his grandmother a gun. Although he surrenders the weapon to her, his seething hatred is obvious.

Baldwin uses Richard to ensure that the reader knows this is not the 14-year old inexperienced little boy who came South for the summer: this is a man, a Southern man, with a man's anger, aimed at the home that continues to treat him as anything other than a man. They treat him like the young boy Emmett Till actually was. That treatment is certainly not unique to Richard; Baldwin displays numerous adult male characters who are treated as lesser entities by their white counterparts. Baldwin also seems to suggest that Richard's anger is not unique. In Notes of a Native Son, Baldwin writes of an experience 
when he was denied service at a restaurant because of his race and he snaps, throwing a glass of water at the waitress (71). The glass misses her, striking and shattering a mirror, and Baldwin — quickly realizing he is about to be pursued — runs:

I could not get over two facts, both equally difficult for the imagination to grasp, and one was that I could have been murdered. But the other was that I had been ready to commit murder. I saw nothing very clearly but I did see this: that my life, my real life, was in danger, and not from anything other people might do but from the hatred I carried in my own heart. (original emphasis; Baldwin, Notes of a Native Son 72)

Anger of this kind, induced after years of mistreatment, can only erupt: "People who treat other people as less than human must not be surprised when the bread they have cast on the waters comes floating back to them, poisoned" (Baldwin, No Name in the Street 472).

Embodying this anger in his introductory scene, Richard appears to flail against anyone and anything he can find: the South, the town, the townspeople, his grandmother, his father, his religion, and the white community in general. Richard, it seems, is pushing and clawing for a breach from the moment he returns to the community. As Baldwin draws him, Richard becomes the breach itself as he permanently — and quickly_divides the town, both in his life and in his death. And perhaps therein lies our discomfort with Richard Henry - he is the physical embodiment of the breach; he is the manifestation of our history, writ large, and without pretense or apology. His death opens the play and reminds us of the original, historical breach — the gruesome murder of Emmett Till. But Richard also reminds us that a powerful black man is a breach in and of himself. Perhaps more importantly, and more painfully, Richard also reminds us that his predecessor, a black boy, was himself a breach. Richard's role as breach is exacerbated by his interactions with his old friend Juanita. With Juanita, Richard becomes increasingly honest and raw. He divulges the secrets of his illnesses - both his addiction to drugs and his obsession with white women. The two become 
united as he "started getting high" to keep from strangling "some pasty white-faced bitch" (Baldwin, Blues 29). Yet, while Richard begins a form of detoxification through his interactions with Juanita, he also finds a new reason to feed his hatred of whiteness. It is from Juanita and her friend Pete that Richard learns of Lyle Britten, and his original encounter with Lyle quickly descends into what could be considered male posturing, if only the stakes were not so high. Lyle jostles Juanita in Richard's presence as he walks by the couple (the intentionality of the act is unclear); already aware of Lyle's reputation as a murderer, Richard boldly (and some critics argue, stupidly) stares Lyle down. Between two men of the same race, such a situation would be less dangerous or would be resolved immediately. Between Lyle and Richard, the situation becomes deadly, as Richard himself knows: "They can rape and kill our women and we can't do nothing. But if we touch one of their dried-up, pale-assed women, we get our nuts cut off' (Baldwin, Blues 25). There is no denying that Richard knows he is demanding a breach; he is desperate for change and ready to cleave society in two to expose that which is rotten within.

The Breach Becomes the Liminal

It is becoming increasingly clear that intrinsic to this scene, and to the play as a whole, is the historical weight Baldwin adeptly juggles throughout Blues. As Tom F. Driver notes, this play is not about civil rights in the common form; it does not deal with issues of economics or constitutionality (Driver 292). Instead, "Baldwin has taken what will seem to many a reactionary step: he has described racial strife as racial strife, warfare between black

${ }^{33}$ Baldwin appears to be taking some of the rumors surrounding Till's behavior and pushing them, as he does throughout the play, into riskier and more blatant behavior. As the opening of this chapter mentions, Till allegedly either showed the local boys pictures of his white friends or white girlfriend back home. Regardless, Richard's relationship with whites, particularly white women, is stronger, more aggressive, and more forbidden in his time. 
people and white people that is rooted in their separate ways of experiencing life, the difference symbolized in their sexuality" (original emphasis; Driver 292-293). Richard's defiance, his arrogance, never strays far from the "threat" of black male sexuality. Indeed, Richard's very attitude, the way he "walks and talks like a man who is aware of his dignity and inherent equality as a human being," is read with a "sexual meaning: it is perceived as sexual assault" (Hernton 112). Although it may be empowering to read Baldwin as suggesting that "Negros... even studious ones, make love better. They dance better. And they cook better. And their penises are longer, or stiffer" (Roth 41), such a suggestion is not without consequences. While Baldwin's focus is not simply, as one reviewer noted, "an attempt...to give the Caucasians in the audience a white inferiority complex," such a "complex" has certainly been noted by white viewers (unknown reviewer qtd. in Littlejohn 73). That "inferiority complex" was often, as it is in this play, combined with the fear of the rape of a white woman by a black man: "if you [a white woman] was to be raped by an orang-outang [sic] out of the jungle or a stallion, couldn't do you no worse than a nigger" (Baldwin, Blues 50). Such "fears" often became excuses that quickly led to grounds for murder, for "Southern justice," in the form of lynching, as discussed in the opening of this chapter.

Richard's initial confrontation with Lyle quickly establishes him as a trouble-maker, a sexual being who does not seem to "know his place," but it is his second confrontation within the confines of Lyle's store that guarantees his murder. As we know, Till's interactions in the Bryant's store changed his own life and the trajectory of the Civil Rights Movement. The store in Baldwin's play, therefore, becomes his clearest and most defined liminal moment. Till and a friend had stopped for a drink after picking cotton all day. Richard, too, emerges 
with a friend after allegedly "toting barges and lifting bales, that's right, we been slaving, and we need a little cool. Liquid. Refreshment" (Baldwin, Blues 71). The scene is thus eerily repetitive; Richard claims to have been "slaving," a clear reference to Emmett Till's cottonpicking (and possibly the cotton gin fan that was used to sink his body).

Once inside the store, Richard insults Lyle's wife, his economic standing, and his manhood, behavior moving well beyond Till's alleged "infractions." Whereas Till may have whistled at the store owner's wife, or even asked her on a date, Richard speaks to Lyle's wife, Jo, in a mocking manner that is so unexpected, she does not immediately understand what is happening. Referring to two bottles of Coca Cola, he states: "Did you put them in this box with your own dainty dish-pan hands? Sure makes them taste sweet" (original emphasis; Baldwin, Blues 72). When neither Lyle nor Jo has change for a twenty dollar bill, Richard moves the verbal attack first to the Britten's economic failings and then out of the public sphere of the store into the personal space of the Britten home; he states "I thought white folks was rich at every hour of the day," and then continues, "I only said you was a lucky man to have so fine a wife. I said maybe she could run home and look and see if there was any change—in the home" (original emphasis; Baldwin, Blues 72, 73). Richard's second comment is doubly offensive. He comments on a white man's wife, and he reemphasizes Lyle and Jo's economic status through the repetition of and emphasis on the word home. Jo must work outside the home in her husband's store to maintain their income; Lyle cannot provide for his family in a way that would allow Jo the luxury of raising her son in the comforts of the home.

What began as covertly defiant behavior becomes outwardly aggressive when Lyle demands Richard leave the store without his drinks and without change for his twenty-dollar 
bill. Richard counters: "You don't own this town, you white mother-fucker. You don't even own twenty dollars" (original emphasis; Baldwin, Blues 74). Richard's touting of his cashmore than the Brittens can change - makes him not only a suspected better lover because of his skin color, but also a better provider. As the historical analysis present in this chapter would suggest, it is not surprising that violence ensues. Amid the physical scuffle between the two men, Richard further questions Lyle's manhood, calling him a "no-good, ball-less peckerwood" (Baldwin, Blues 74). The insult is carefully placed and ironic if we recall Richard's earlier statement made at the mention of Lyle Britten: "They can rape and kill our women and we can't do nothing. But if we touch one of their dried-up, pale-assed women, we get our nuts cut off' (Baldwin, Blues 25). Here he turns the tables; the white man, it seems, is self-castrated either by the white woman, his own hatred, or simply by his whiteness. After emerging from the fight victorious, Richard cannot simply walk away. Whether Richard recognizes it or not, his ending, after insulting Lyle and his wife, is already written. He delivers his final death knell, however, by raising the one issue not yet overtly stated: "Look at the mighty peckerwood! On his ass, baby—and his woman watching! Now, who you think is the better man? Ha-ha! The master race! You let me in that tired white chick's drawers, she'll know who's the master! Ha-ha-ha!' (my emphasis; Baldwin, Blues 75). Richard raises the taboo, the pervasive threat of black masculinity: the rape of the white woman.

While the store itself, the cotton-picking reference, and the involvement of the store owner's wife are all meant to recall Till, Baldwin clearly uses this liminal moment to introduce heightened tensions. As Nietzsche tells us, "To think objectively, in this sense, of history is the work of the dramatist: to think one thing with another, and weave the elements 
into a single whole, with the presumption that the unity of plan must be put into the objects if it is not already there" (37-38). Baldwin must "think one thing with another" and "weave" enough of the past into the scene to connect the moments, while also pushing the limits of Richard's behavior. Certainly, Baldwin removes Till's youth, his innocence, and his vulnerability, instead offering us a character who is intentionally defiant and knows the consequences. In fairness, however, the media had already attempted such a transformation with Till during the trial. The Mississippi newspapers began repeatedly referring to Till as "husky," a fact acknowledged by Houck and Grindy who sarcastically note “... above all else, size mattered to aggrieved white southern men - and Till had clearly grown in stature in three short weeks" (74). Knowing the ways of her hometown, Till's mother allegedly warned him to know his "place" before sending him South, stating, "even if you have to get on your knees and bow when they (white person) [sic] pass, do so willingly" (qtd. in Houck and Grindy 29). Richard, however, was raised in the South, unlike Till, and knew the expectations. Discussing the expected role of the black man in America, Baldwin writes:

We do not know what to do with him in life; if he breaks our sociological and sentimental image of him we are panic-stricken and we feel ourselves betrayed. When he violates this image, therefore, he stands in the greatest danger (sensing which, we uneasily suspect that he is very often playing a part for our benefit); and, what is not always so apparent but is equally true, we are then in some danger ourselves--hence our retreat or our blind and immediate retaliation. (Baldwin, Notes of a Native Son 20)

Both Till and Richard Henry break the mold; both act outside of expected norms. But only one does it with apparent forethought and understanding. 
"It had to be a nightmare..."34

It is easy to see, through this scene, how critics can read Richard Henry as the harbinger of his own murder. There is a part of any reader that simply wants to quiet Richard, to ask him not necessarily to quell his hatred, but rather, to save his own life. There are other critics, however, who find a form of smug vindication in Richard, who question why he should have to be quiet to save his own life in the face of historical and ongoing race injustice and race hatred. Richard exudes, for these critics, a form of strength and freshness (all connotations included). Such critics may recognize Richard's seeming drive toward death, but exalt him for his brutal honesty. Calvin Hernton appreciates Baldwin's "realistic" grappling with such events and precedents: "We 'liberals' in America always want justice to win out in the end. Well, in the South there is no justice when it comes to the Negro. And Baldwin wrote it as it really is. The murderers of countless Emmett Tills are still running amuck throughout the entire South" (112). Hernton, like most readers, does not see or recognize Lyle's view of "justice," for indeed, Lyle feels that he has rendered white justice: "I had to kill him then. I'm a white man! Can't nobody talk that way to me!" (original emphasis; Baldwin, Blues 120). Unlike Lyle, Hernton sees no justice-and no hope for justice-in Baldwin's Blues. In lieu of justice, then, Hernton finds truth and defiance. Darwin T. Turner (1977) sees Richard's life as offering hope, or at least vindication, in a similar fashion - "Furthermore, the play appealed to many young blacks because Richard Henry was the first black stage character in their lifetime to attack white society boldly" (D. Turner 191). If Baldwin cannot give us Richard's (or Till's) justice, such critics would

\footnotetext{
${ }^{34}$ See full quote on page 91.
} 
argue, he can give us Richard's boldness. It remains difficult to accept, however, that we cannot have both.

Even if we had not already witnessed Richard's murder at Lyle's hands at the opening of the play, as viewers and readers we still must know that this scene, Baldwin's most liminal moment, can only have one conclusion. Baldwin's ending has therefore been chosen for him:

What other way_authentically — could Baldwin have conceived his piece, considering the material he had chosen? For it is not only a dramatic use of the Emmett Till lynching, but it is also a distillation of all the maimed and lynched, all the brutish sadism of three centuries of the Negro's American experience. It had to be a nightmare to be authentic, and it had to be a blues, a Blues for Mister Charlie. (original emphasis; Turpin 195)

This feeling of necessity—of being unable to write the play in any other way—is supported by Nicholas K. Davis:

The present moment in Baldwin's writing is thus always two undivorceable things: a culmination of preexisting patterns that can only now be appreciated, and a decisive, epiphanic break in the protagonist's life where genuine change seems within reach, even though a later moment of history or memory will see this, too, as an embedded moment within a revised larger pattern. Free will and historical fatalism cannot be separated in Baldwin, who refuses to dispense with either of them, however much each seems to diminish the claims of the other. (34)

Past and present—one actual, one fictional—are presented simultaneously. But Baldwin is not just showing us the past revisited. He is making Richard an intentional, thinking breach, one who forces himself into his Southern hometown and refuses to occupy predetermined spaces and personas. Baldwin asks Richard to face the necessity of history-in this case death—but to do it knowingly, angrily, and confrontationally. This is a conscious act (if not for Richard, then for Baldwin), a reclamation, and a refusal. As Bhabha notes, "despite the 'play' in the colonial system which is crucial to its exercise of power, colonial discourse 
produces the colonized as a social reality which is at once an 'other' and yet entirely knowable and visible' (101). Herein lies the power and the resistance in Baldwin's postcolonial Richard: he is unknowable and unpredictable. He is the threat of destruction and disruption via the assertion of power and choice.

Thus, while Richard is clearly parodying his own race's history (he has, as far as the reader knows, been nowhere near a cotton field), Baldwin is not parodying the Emmett Till murder. Instead, Baldwin attempts to create a fatalistic cry for a boldness that simultaneously struggles against injustice while calling forth additional injustices: because no one here—-Richard Henry and Emmett Till included — deserves to die, violence and death must ensue in order to attempt to end future violence and death. Choice and power should not equate to murder, even if here they must. Redress and resolution, Baldwin suggests, will require the scene to be played out yet again —a return to crisis— but with the possibility of a different ending.

Confrontation, then, in the form of drama is Baldwin's key for moving forward. As Baldwin notes, "The paradox — and a fearful paradox it is—is that the American Negro can have no future anywhere, on any continent, as long as he is unwilling to accept his past. To accept one's past—one's history—is not the same thing as drowning in it; it is learning how to use it" (The Fire Next Time 333). Baldwin rewrites history in the name of growth, acceptance, and mastery. He murders Richard to "accept his past" while also "learning how to use it." Baldwin tries to tell his viewers and readers that theater is both a mimetic of that which exists (here, the negative) and the impetus for a new reality, where we no longer accept that the past defines our future. Theater is at once mimetic and proto-mimetic, that which is imitated and that which will one day be imitable, or what Turner dubs "life by art, 
art by life" (From Ritual 108). There will be a time, Baldwin posits, when Richard Henry will not have to die. Better yet, there will be a time, Baldwin posits, when Richard Henry will not need to be defiant. Only by confronting our past can we challenge it.

Theater is the ideal stage for Baldwin's claims of the past and his demands for the future. As Turner argues:

Theatre is, indeed, a hypertrophy, an exaggeration, of jural and ritual processes; it is not a simple replication of the 'natural' total processual pattern of the social drama. There is, therefore, in theatre something of the investigative, judgmental, and even punitive character of law-in-action, and something of the sacred, mythic, numinous, even 'supernatural' character of religious action--sometimes to the point of sacrifice. (From Ritual 12)

Richard is an "exaggeration"; this story is not the story of Till, but the story Baldwin makes using Till as his guide. There is something bold and "investigative, judgmental, and even punitive" in this drama. There is even, one could argue, the "sacrifice" of Richard. But these moments exist because the real "jural" processes have failed. What is left is this confrontation, this warning that future jural and recessive means can no longer fail. Baldwin calls on all of us to do better and to be better.

Richard Henry/Emmett Till as Abject

As we have noted, most critics dismiss or denigrate Blues because of Baldwin's characterization of Richard - a characterization that wavers between strength and suicide, free will and fate. I argue, however, that it is this very characterization that gives Richard the power of possibility. As evidenced in the play's pivotal liminal moment, the scene in the Britten's store, Baldwin cannot outrun history in this play, but he can challenge it. Richard's ability to choose his fate makes him dangerous. By becoming the breach via action rather than suffering the effects of the breach via reaction, Richard offers a small but incredibly powerful difference. Using the psychoanalytic theories of Julia Kristeva, the viewer/reader 
can begin to see how Baldwin, via Richard, creates the space for the possibility of redress, if not eventual resolution.

Baldwin begins to create such a space with the opening of the play, a moment of starting that corresponds with Richard's moment of ending; in Blues, the opening scene portrays Lyle Britten's dumping of Richard's body off the stage: “And may every nigger like this nigger end like this nigger-face down in the weeds!" (Baldwin, Blues 2). It is a moment that instantly recalls the murder of Till, whose body was dumped into a river where he remained submerged for several days. Kristeva, in the Powers of Horror, illustrates what happens at this critical juncture when the living face the dead:

...refuse and corpses show me what I permanently thrust aside in order to live. These body fluids, this defilement, this shit are what life withstands, hardly and with difficulty, on the part of death. There, I am at the border of my condition as a living being. My body extricates itself, as being alive, from that border. [....] If dung signifies the other side of the border, the place where I am not and which permits me to be, the corpse, the most sickening of wastes, is a border that has encroached upon everything. It is no longer I who expel, 'I' is expelled. The border has become an object. How can I be without border? [...] The corpse, seen without God and outside of science, is the utmost of abjection. It is death infecting life. Abject. It is something rejected from which one does not part, from which one does not protect oneself as from an object. Imaginary uncanniness and real threat, it beckons to us and ends up engulfing us. (3-4)

Although the encounter with the corpse is brief, its importance is magnified simply because it opens the play and recalls its tragic predecessor-Till. Faced with a corpse immediately, then, the reader/viewer (but most especially the viewer) is forced to acknowledge the abject, defined by Kristeva as that which "disturbs identity, system, order. What does not respect borders, positions, rules. (The in-between, the ambiguous, the composite)," which could also be used to describe the liminal (Powers of Horror 4). Facing the abject, the reader/viewer feels the shrinking of personal borders and boundaries. His/her own life becomes frailer, 
suspect, removable, destroyable. Since Baldwin opens the play with Richard's death, the abjection — the border breakdown — is even more insidious. The viewer has no understanding of Richard's character or his potential crime. S/he has only a white man carrying a dead black body and dropping it in the weeds. This scene is duplicated at the end of the play when the audience sees, through a flashback, Lyle kill Richard once again. For a second time, the audience is reminded of the breakdown of boundaries and quickly comes to understand that Lyle drops "such wastes" so that his "I," his sense of self and race, "might live." This separation, this pushing away of the other for the definition of the self, can equally be applied to Till's murderers.

Adding to the difficulty of the opening scene are the opening words through which Lyle augments the feelings of abjection. Not only is there a corpse, the "utmost of abjection," but there is also Lyle's language which screams of abjection: "And may every nigger like this nigger end like this nigger-face down in the weeds!” (Baldwin, Blues 2). Linking language with the naming of the abject, Kristeva writes that "emotion, in order to make itself heard, adopts colloquial speech or, when it acknowledges its hatred straightforwardly, slang," and thus, Lyle's repeated use of the word "nigger" becomes his audible acknowledgement of his hatred (Powers of Horror 191). Kristeva continues: "The vocabulary of slang, because of its strangeness, its very violence, and especially because the reader does not always understand it, is of course a radical instrument of separation, of rejection, and, at the limit, of hatred" (Powers of Horror 191). Thus, Lyle uses slang to continue separating himself from Richard, from abjection (both in the form of Richard's being black and in the form of Richard being a physical corpse). 
Lyle names his abjection as he also defines himself against it. Kristeva states, "The abject has only one quality of the object— that of being opposed to I" (original emphasis; Powers of Horror 1). For Lyle, Richard is “opposed to I." Lyle defines himself, his whiteness, in opposition to Richard, as evidenced by a similar form of repetition in a speech found at the end of the play when Lyle addresses Parnell: "What's the matter with you? Have you forgotten you a white man? A white man! My Daddy told me not to never forget I was a white man!" (original emphasis; Baldwin, Blues 117). The somewhat ironic use of the double negative aside, Lyle completes the cycle of abject and object construction he begins in the opening of the play. Lyle opens the play decrying Richard's blackness-his abjection—over the dead, black body; Lyle closes the play affirming his own prideful whiteness—-himself as constructed object—in contrast or opposition to such blackness. Lyle's creation of the self as opposed to the abject may seem extreme, but such a formulation is again historically based. Bryant and Milam, Till's killers, allegedly gave a full interview to Look magazine after their trial in which they admitted to the murder; two local newspapers leaked the story before the article could be published. In the article, we learn that Milam told Till, "Chicago boy, I'm tired of 'em sending your kind down here to stir up trouble. Goddam [sic] you, I'm going to make an example of you—just so everybody can know how me and my folks stand" (qtd. in Houck and Grindy 150). Milam then shot Till. Milam distances himself from Till twice in his speech, once when he calls him a "Chicago boy," making him an other in that he is not from the South, and once again when he makes him the opposite of "me and my folks." As seen repeatedly, Baldwin intensifies this language, this scene, and this separation in order to generate a more powerful play and a more polarizing set of characters. 
This separation that Lyle, Milam, and Bryant create is critical. For Lyle, Richard is the breach and the subsequent crisis. He forces Lyle to choose a side and Lyle takes it upon himself to choose his means of redress and resolution: the murdering of Richard. For Lyle, the cycle is resolved and complete when he dumps Richard's body out of sight. As Baldwin notes in his description of men like Lyle Britten, "I am aware that no man is a villain in his own eyes," and that description holds true for Lyle, who sees himself as savior-like ("Notes for Blues" xiv). Milam and Bryant can be seen in much the same light. Till, for them, is disruptive and needs to be made into "an example" for others. Doing so, in their minds, reestablishes the racial balances and ends the breach/crisis. For the audience of Baldwin's work, for the townspeople in the play, and for the actual American public, however, the outcome is different. Richard, who pushed against society to become a breach in the small town, has now become a crisis as blacks and whites rally to choose sides for and against Lyle. Till, who acted with much less intentionality, becomes a pivotal figure, a breach and a crisis, who contributes to another breach and crisis in the form of the Civil Rights Movement. $\underline{\text { Richard as Deject }}$

Baldwin does endow Richard with a very different personality than Till. While it is clear that Lyle sees Richard as abjection, as opposite to $I$, the reader can also see Richard as seeing himself as abjection, as what Kristeva terms a "deject," thus stepping outside the realm of the expected, breaking borders, and refusing to admit accepted boundaries. Kristeva calls the deject one "by whom the abject exists" and one "who places (himself), separates (himself), situates (himself) and therefore strays instead of getting his bearings, desiring, belonging, or refusing" (original emphasis; Powers of Horror 8). Thus Richard cannot stay, physically, in one location — moving from the South to New York and then planning to leave 
the South again, this time with Juanita. He separates himself from his family by denouncing his father's weaknesses, turning away from God, and refusing the morality his family teaches: “We don't see things the same way, Grandmama. I don't know if I really know right from wrong —I'd like to, I always dig people the most who know anything, especially right from wrong!" (original emphasis; Baldwin, Blues 18). Richard attempts to find roots in the South, with his family, by handing over his gun to his grandmother and by re-establishing a relationship with Juanita. Ultimately, however, he remains an outsider, an other.

It seems, at times, that Richard tries very hard to maintain such an othering. But, indeed, that is part of being a deject; one must "situate" oneself and one must "stray." Both verbs require a form of conscious thought and decision. Thus Richard taunts his own friends and acquaintances, creating a distance: "I got a whole gang of white chicks in New York. That's right. And they can't get enough of what little Richard's got—and I give it to them, too, baby, believe me" (Baldwin, Blues 25). He similarly attracts and repels his own family, at once disrespecting and loving his grandmother while disrupting and recreating a relationship with his father. Critic Emmanuel S. Nelson, in “James Baldwin's Vision of Otherness and Community" (1983), claims the following regarding this relationship between Richard and his friends and family:

In the beginning, Richard perceives the humiliations of his racial past as signs of weakness and tries to define himself in opposition to that collective experience. But as the play moves along, he becomes increasingly sensitive to the beauty and strength that have come out of the appalling suffering of his people. It is in his gradual identification with the collective, communal Black experience from which he had originally alienated himself that he finds his self and strength. (123)

Contrary to Nelson's statement, however, Richard does not ultimately find beauty, strength, or identification in his community. Instead, he finds an indescribable internal resistance that 
can only be explained by his role as deject. Thus, while Nelson may very well be deriving his argument from Richard's attempts to establish relationships within the community—with Juanita (whom he possibly impregnates), his father, or his grandmother - such forays into the community do not limit his ability to stand as deject. Indeed, by continually resisting "that collective experience" and by needling and at times augmenting the "appalling suffering of his people," Richard consistently redefines his position as chosen outsider, as breach.

Richard's small moments of effective communication with friends and family do not limit his role as deject for, as Kristeva notes, the deject is "Situationist in a sense, and not without laughter — since laughing is a way of placing or displacing abjection" (Powers of Horror 8). Richard's laughter, then, displaces abjection when he reaches out to his family, but places abjection — on himself and the white community—when he laughs at Lyle and Jo in their store, or when he uses sarcasm even while Lyle shoots him: “Okay. Okay. Okay. Keep your old lady home, you hear? Don't let her near no nigger. She might get to like it. You might get to like it, too. Wow!" (Baldwin, Blues 120).

Richard's laughter is consistent not only with his role as deject, but also with the role of rebel - another related position that places him outside the boundaries of normal and acceptable behavior. In The Sense and Non-Sense of Revolt (2000), Kristeva argues that some form of revolt or rebellion is indeed necessary to happiness as "happiness exists only at the price of a revolt" (Sense and Non-Sense 7): "None of us has pleasure without confronting an obstacle, prohibition, authority, or law that allows us to realize ourselves as autonomous and free" (Sense and Non-Sense 7). Richard takes pleasure in pushing the boundaries beyond the normal levels of rebellion or revolt. While Juanita, Mother Henry, Meridian, and the local black community carry signs of protest at organized meetings, Richard's happiness 
comes from a more blatant, unexpected, raw form of protest. Richard is, using Driver's words, the embodiment of "the breakdown of 'moderation' in the face of antagonisms that are by nature irrational and immoderate" in the play (292). More than simply a "breakdown of 'moderation,"' however, Richard takes real enjoyment in humiliating whites, even at the very moment of his own murder: "You can't eat because none of your sad-assed chicks can cook. You can't talk because won't nobody talk to you. You can't dance because you've got nobody to dance with — don't you know I've watched you all my life? All my life! And I know your women, don't you think I don't_-better than you!" (original emphasis; Baldwin, Blues 119). Richard's only true joy comes from such interactions, where ironically, facing death, his "confronting" of "authority" "allows" him to feel "autonomous and free" (Kristeva, Sense and Non-Sense 7). It is important to note that Baldwin is not representing Till in this part of Richard. Instead, he makes Richard a true, self-chosen outsider (rather than simply a visitor from the North), in order to highlight the problems inherent to the time and the South.

Seeing Richard as deject helps the reader to understand his erratic behavior which otherwise becomes paradoxical, as Carlton W. Molette notes in "James Baldwin as Playwright" (1977):

Richard Henry thinks he must destroy 'Mister Charlie' in order to achieve his own salvation. On the other hand, he knows that the system is programmed to destroy him if he attempts to destroy the man. He knows that he cannot realistically expect to beat the whole system singlehandedly. So he knows that his act of destruction perpetrated against 'Mr. Charlie' will inevitably result in his own destruction. Yet he wants to live. He is not suicidal. Still a third paradox. (187)

Richard is the non-suicidal deject who nonetheless asks to die because, as Kristeva describes, "He has a sense of danger, of the loss that the pseudo-object attracting him represents for 
him, but he cannot help taking the risk at the very moment he sets himself apart. And the more he strays, the more he is saved" (Powers of Horror 8). Richard's "pseudo-object" can be seen as death, or it can be seen as Lyle (and while they are related, they are not identical). Either way, both represent abjection, to which Richard is drawn. He and Lyle thereby enter a symbiotic relationship; they define themselves against one another, they constantly struggle to maintain separate identities in each other's presence, and they experience similar emotions of rage, hatred, violence, and disgust. It is true that Richard provokes Lyle, but Lyle clearly needs little provocation, especially given that this is not, indeed, his first murder of a black man. The historical weight of racism in the play determines which abjection must be removed, but it is this very danger of removal that excites Richard. The danger, the moving away from the acceptable boundaries of his community, makes him feel "saved," useful, and powerful. Thus, while his actions may result in his moving from deject to abject (a corpse), it is the act of setting himself apart — the crossing and denying of boundaries—not the death, that drives him.

Baldwin theorizes about this struggle for African Americans generally when he writes:

And there is, I should think, no Negro living in America who has not felt, briefly or for long periods, with anguish sharp or dull, in varying degrees and to varying effect, simple, naked and unanswerable hatred; who has not wanted to smash any white face he may encounter in a day, to violate, out of motives of the cruelest vengeance, their women, to break the bodies of all white people and bring them low, as low as that dust into which he himself has been and is being trampled; no Negro, finally, who has not had to make his own precarious adjustment to the 'nigger' who surrounds him and to the 'nigger' in himself. (Baldwin, Notes of a Native Son 29)

Baldwin writes of the internal struggle generated by external pressure. Taking this feeling that may be experienced only briefly in reality, he applies it to Richard Henry and defines 
Richard Henry with it. But he has not forsaken history here either. For it is the murder of Till, the subsequent miscarriage of justice, and the racism that makes it all possible that crystalizes this feeling into a character in a play, into Richard Henry himself. And Richard is, if nothing else, meant to bother the viewer/reader, meant to remind him/her of the breach, and meant to keep the crisis alive. The play is a means of redress, but redress through the continued crisis for resolution is far from possible.

\section{$\underline{\text { Father Figures }}$}

Baldwin symbolizes this break with the past, this re-inscribing of the breach, via Richard Henry's own relationship with the past in the figure of his father. Indeed, Richard's desire to set himself apart centers largely on his desire to break the father/son cycle that begins to repeat itself in Blues. While Richard moves up North to join his aunt following his mother's death (or murder, if the reader chooses to accept Richard's opinion), he returns home after getting into trouble with the law regarding his drug use. He immediately begins a relationship with his old friend/girlfriend, Juanita, telling his father, "Lord, if I'd stayed here, I guess I might have married old Juanita by now, and we'd have a couple of kids and I'd be sitting around like this every night. What a wild thought" (original emphasis; Baldwin, Blues 34). Richard admits to considering such an option only after Meridian admits to having considered marrying Juanita himself, although he has "never spoken of it to her" (Baldwin, Blues 35). Richard's plans for the future, then, become a symbol of his continuing a cycle. He would, like his father, remain in/return to the South, live a more reserved life (since he certainly could not survive a life in the South otherwise), and marry a beautiful woman similar to his mother. Indeed, Juanita is so similar to his mother that she almost is his 
mother, or at least his step-mother. Baldwin thereby re-emphasizes, all too clearly, what Richard almost does — he almost selects a life identical to his father's.

But what is gained from breaking the cycle? Turning again to Kristeva's later work, The Sense and Non-Sense of Revolt, the reader can begin to see the impact of Richard's rebelliousness, of his role as deject and breach. Kristeva paraphrases Sigmund Freud's Totem and Taboo, commenting on the oedipal complex present in all of us (Sense and NonSense 12). According to Freud, all men originally lived under the rule of a dominant head of the horde who "demanded total submission from his sons and prohibited access to women, the sexual enjoyment of whom he reserved for himself" (Kristeva, Sense and Non-Sense 12). The sons eventually revolt, killing the father and eating him in a totemic meal, thus coming to identify with the totem they have consumed. Guilt and repentance bind the brothers and "the dead father became stronger than the living one had been" (Freud 143), forcing them to obey and reinforce the same laws that originally drove them to murder.

Richard, then, has a number of options related to this particular form of revolt or rebellion. He clearly sees his father as a figurehead of a type of power; Meridian's control over his son stems from Meridian's perceived legacy of debilitating powerlessness. This lack of power — this inability to avenge his wife's death or effectively raise his son—becomes a controlling force over Richard. Indeed, Meridian seems to represent an overall lack of black, masculine power in the community, a fact that further enrages his son. Richard remembers his father's reaction to his mother's death: "But he wasn't there, he didn't know, he couldn't do nothing. I'll never forget the way he looked—whipped, whipped, whipped, whipped!” (original emphasis; Baldwin, Blues 20). He later tells his father of his own reaction, "You didn't want me to look at you and be ashamed of you. And you didn't know what was in my 
eyes, you couldn't stand it, I could tell from the way you looked at me sometimes. That was it, wasn't it?" (Baldwin, Blues 35). In order to escape the despotic dearth of power that binds Richard to his father and his community, Richard could choose, in the way of Freud, to murder the father. Such a reaction is too consistent with the father's perceived lack of power to truly form any sort of rebellion, however, and Richard cannot, of course, murder his community or alter his race. Richard could choose to remain in town with Juanita, or flee town with her, but he is still haunted by the imposing image of his "whipped" father, complacent townspeople, and possibly murdered mother. Richard attempts drugs, music, moving North, and sleeping with white women, but he is consumed nonetheless by a powerful rage against anything — a rage that must ultimately be directed at something. In order to escape his father's cycle of non-action, in order to escape his father's (and community's) legacy of failure, Richard must do what his father and community will not: Richard must fight Mister Charlie, even if it means his own death. Richard is driven by the need to replace powerlessness with power-the power of decision and action—but his rebellion is ironically tied to the continuation of powerlessness, in this case, his own death.

Twisting the Freudian concept, then, Richard murders - directly or indirectly— himself in lieu of murdering the father. Alternatively, the reader can see Richard as murdering the father in himself, the father figure he was starting to become by considering life choices similar to those Meridian had already chosen. Either reading, however, has the same outcome: Richard leaves his father behind — along with his friends, family, and community - bound by guilt and repentance, to perpetuate the cycle the son has begun.

Indeed, following Richard's murder, Meridian begins to question his own faith in both God and eventual change, and he begins to blame himself for the murder of his son and 
wife: "If you're a black man, with a black son, you have to forget all about white people and concentrate on trying to save your child. That's why I let him stay up North. I was wrong, I failed, I failed. Lyle walked up the road and killed him" (Baldwin, Blues 40). Meridian's guilt and anger grow as the play progresses: "Yes! I am responsible for the death of my son! I—-hoped - I prayed - I struggled — so that the world would be different by the time he was a man than it had been when he was born. And I thought that — then—when he looked at mehe would think that I—his father—had helped to change it" (original emphasis; Baldwin, Blues 104).

Meridian, however, realizes he misplaced his faith and his belief in the inevitability of change, and sees his own slow realization as leading to his son's death. That guilt creates Meridian's moment for personal change, and raises his demands for societal change, even if that means challenge and strife:

I am a man. A man! I tried to help my son become a man. But manhood is a dangerous pursuit, here. And that pursuit undid him because of your guns, your hoses, your dogs, your judges, your law-makers, your folly, your pride, your cruelty, your cowardice, your money, your chain gangs, and your churches! Did you think it would endure forever? that [sic] we would pay for your ease forever? (Baldwin, Blues 103)

Meridian's shift, motivated by guilt and repentance, includes warning Parnell, a white friend of the Henry family and of Lyle Britten, about the future violence that will strike the town while questioning his prior conviction not to arm (Baldwin, Blues 37). As Driver notes, Meridian's shift is one of the most important movements in the play: "Among the blacks, the most important reaction we watch is that of the boy's clergyman father [...]. He has long been a spokesman and a bargainer for civil rights. He becomes an agitator ready to take up arms" (292). Meridian's growing militancy also affects his parishioners and the community he leads - pushing them closer and closer to full-scale resistance and revolt. His changing 
convictions, however, cannot assuage his guilt: "Would God—would God—would God I had died for thee - my son, my son!" (Baldwin, Blues 43). Ultimately, however, like the story of Christ he references, Meridian cannot die for his son. It is, in fact, his son who must die to alter the life of his father/community.

Meridian's shift toward violence, unfortunately, runs the risk of eliminating one of his previous strengths, a strength Richard clearly lacks: the ability to survive. Meridian moves from a position of survival into a more violent posture, reflecting the revolution of his son. However, as Freud and Kristeva both note, the sons (or in this case, the ones left behind) often remember and commemorate the revolt, but such a movement seeks "to mimic this revolt" but "not to reproduce it exactly" (Kristeva, Sense and Non-Sense 13). Thus, like the outwardly moving ripples in a pond, the reader can expect (or at least hope for) such a revolution to spread while losing some of the self-destructive power of initial assault.

\section{Other Effects}

Richard's revolt, in the form of defying white expectations, affects more than just Meridian; it also affects his surrounding black community, most clearly articulated in the changes evident in Juanita. If she is indeed pregnant, she will clearly be visibly changed, but she is also poised to raise a son similar to Richard: "I hope I'm pregnant. I hope I am! One more illegitimate black baby — that's right you jive mothers! And I am going to raise my baby to be a man. A man, you dig? Oh, let me be pregnant, let me be pregnant, don't let it all be gone! A man. Juanita. A man" (original emphasis; Baldwin, Blues 94). Juanita has moved from herding Richard away from danger-“Just stay out of white places” (Baldwin, Blues 30) - to creating a son in his image (even if such a creation is only in her mind):

And we tried to make plans to go, but he said he wasn't going to run no more from white folks — never no more! — but was going to stay and be a man-a 
man! - right here. And I couldn't make him see differently. I knew what he meant, I knew how he felt, but I didn't want him to die. (Baldwin, Blues 99)

In both instances, Juanita repeats "a man" several times as she is, in her own mind, redefining what it means to be a man, to be a black man. Meridian, it should be noted, uses the same repetition later, as he too begins to redefine manhood: "I am a man. A man! I tried to help my son become a man" (Baldwin, Blues 103). Such repetition echoes Lyle's use of repetition in the opening scene of the play. Juanita and Meridian demonstrate the essential shift in the play, however, as Lyle's "nigger" is redefined as a "man."35 Thus, Juanita hopes to have a son who can, bound by the legacy he has been left, continue to refuse "to run" from "white folks." Such a refusal, she hopes, will become increasingly nuanced and supported so as to continue the rebellion without ending more black lives.

Much of this redefinition of manhood that Meridian and Juanita emphasize revolves around Richard's denial of the "automation" that has settled into his small southern town. As Kristeva notes, people, "faced with the religious and political impasses of our time," often find that "an experience of revolt may be the only thing that can save us from the automations of humanity [...] threatening us" (Sense and Non-Sense 7). For Kristeva, the lack of real political power, manifested in the desire for figureheads and scapegoats, combined with a consumer culture that makes entertainment more important than growth or development, form a complacent, rebellion-less society. For Richard, surrounded by a town of people who protest and struggle only within certain boundaries, such automation is suffocating. The expectations of such automation are clear: people fulfill their roles based on color, or they forfeit their lives or reputations. Thus, Lyle kills Richard for questioning

\footnotetext{
${ }^{35}$ This repetition, it is important to note, also re-enforces the differences between Emmett Till and Richard Henry: Henry is a man; Till was still just a boy. The viewer/reader is subtly and repeatedly reminded of what Till was never allowed to become.
} 
his right to behave in any way he sees fits, and Parnell becomes "worse than a nigger" for his attempts to defend the reactions of the black community to Richard's murder (original emphasis; Baldwin, Blues 53). Similarly, the defense in Milam and Bryant's trial closed by telling the jury, "Every last Anglo-Saxon one of you has the courage to free these men" (qtd. in Houck and Grindy 104). Of course, since Milam and Bryant are on the "right" side of privilege, such automation is considerably less stifling and considerably more freeing, a point Baldwin works hard to point out through his drama.

In fighting against automation, Richard Henry, like Emmett Till, is murdered. But the character, like his historical predecessor, upsets the normalizing order most effectively through his death. ${ }^{36}$ Emmett Till's murder, while undoubtedly tragic, sparked a cause that reached well beyond his own life or murder. As Myrlie Evers wrote: "young Emmett Till became in death what he could never have been in life: a rallying cry and a cause" (171). In a similar way, Richard's murder can be seen to accomplish more than his life would have. Richard's attempts to infuse his own sense of defiance and rebellion into his friends and family are repeatedly thwarted as Mother Henry tells him to "just try not to go so much, try to calm down a little," and Papa D. tells him to put away the pictures of white women he carries with him: "I thought you had good sense" (original emphasis; Baldwin, Blues 18, 27). Meridian and Juanita, too, maintain their views on race relations while Richard is alive,

\footnotetext{
${ }^{36}$ Koritha Mitchell, in her article "James Baldwin, Performance Theorist, Sings the Blues for Mister Charlie," takes great exception to my suggestion that Richard and Till are potentially greater change-agents in death than society would have allowed them to be in life. I by no means attempt to suggest that their murders are "good," but rather that they become catalysts for change that far exceed their control or understanding. Mitchell sees Baldwin's play as not, in fact, being told through flashbacks, but rather she suggests that Richard "materializes in response to living characters" (50). She suggests we see Richard as "characters remember him," a view my reading disputes, but one that causes Mitchell to see Richard as not effecting change through his death but rather through his living-memory (51).
} 
opting for religion and patient protest until after the murder. It is only after Richard is killed that Juanita wishes to grow out her hair "the way God arranged it in the first place" while hoping to raise her son to militancy (Baldwin, Blues 37). And it is only after the murder that Papa D. breaks his relationship with Lyle, turning on him on the witness stand. Meridian, too, turns his faith away from acceptance and towards anger. These changes, while small, are the beginnings of a stronger sense of self-awareness and pride. They are the seeds for a later, stronger revolution.

Like Richard Henry and Emmett Till, James Baldwin also found a way to upset the normalizing order - this time the order of 1960s American theater-with Blues for Mister Charlie. In a 1984 interview, James Baldwin spoke about his controversial essay “Everybody’s Protest Novel," his views on victimization novels (such as, in Baldwin's opinion, Native Son), as well as his role as a writer, asserting, "I was convinced then — and I still am - that those sort of books do nothing but bolster up an image" (Baldwin, Conversations 237). It was an image Baldwin was unwilling to support or sanction: "it seemed to me that if I took the role of a victim then [...] they could pity me and add a few more pennies to my home relief check" (Baldwin, Conversations 237). It is clear, given Baldwin's views on victimization, that Richard Henry cannot be simply a victim. He is, by Baldwin's own assertion, not pitiable. He must be, on some level then, multi-dimensional, culpable, and human; we are meant to read his murderer, Lyle, in much the same way. Both characters are presented as possessing overpowering emotions, deep beliefs in autonomy, and a strong sense of "justice." While Baldwin was clearly bound by the historical precedent that surrounds this play, he did not choose to simply provide an Emmett Till, a victim, who is too young and too naïve to make rational, adult choices. Richard makes his choices - regardless 
of what the viewer/reader thinks of them, or him. His choices reflect those of a deject, a rebel, and a breach personified who desires nothing more than to step outside the lines of a racially troubled society. He uses confrontation to emphasize the failures in American society, white and black. In doing so, he pays the ultimate price. But it is not a price without reason or consequences. Richard chose revolution and his choice influences a fictional community; Baldwin hopes that choice, that confrontation, that challenge, will carry over into our own community. 
CHAPTER 3: CONDEMNATION AS REDRESS: HERMAN MELVILLE'S BENITO

CERENO, RICHARD WRIGHT'S MAN, GOD AIN'T LIKE THAT ..., AND ROBERT LOWELL'S BENITO CERENO

Unlike the other dramas in this study, neither Herman Melville's Benito Cereno nor Richard Wright's Man, God Ain't Like That... was written for the stage. Melville's wellknown novella, itself a revision of a historical document, was originally published serially in Putnam's Monthly in 1855 and later released in a collection of Melville's works. And, while many critics have erroneously dubbed Wright's piece a short story (likely due to its inclusion in Wright's collection of stories, Eight Men, published in 1961), it was originally commissioned - and aired - as a German radio play, which explains why this "short story" is written entirely in dialogue. Wright's dramatization is a revision of Melville's own revision, and while Wright meant it to be heard and not seen, it is nonetheless a piece, like the others in this study, meant to be performed.

Unlike its predecessors, Robert Lowell's Benito Cereno was designed for the traditional stage. The work appears in a trilogy of plays, The Old Glory, originally performed off-Broadway in New York City's The American Place Theatre in 1964. The trilogy was the winner of five Obie Awards for the season, including Best Play. The first two plays in the trilogy, Endecott and the Red Cross and My Kinsman, Major Molineux, are based on Nathaniel Hawthorne's short stories of the same names. Lowell's Benito Cereno, like Wright's Man, God, is based on Melville's novella. 
All four pieces-if one counts the original historical document that precedes and serves as the basis for Melville's work—attempt to define and grapple with troubled American (and international) race relations from 1799 until the mid 1960s. The ongoing need for revisions indicate the ongoing presence of white domination, the continuous fight for improved race relations, and the consistent struggle for a more equitable future.

\section{Defining the Past, Understanding the Present I: Amasa Delano and Herman Melville} The 1817 Narrative of Voyages

The original text in this study is itself a piece of non-fiction, albeit one fraught with narrative difficulties. In 1817, American ship Captain Amasa Delano published his 598-page tome, Narrative of Voyages and Travels in the Northern and Southern Hemispheres: Comprising Three Voyages Round the World; Together with a Voyage of Survey and Discovery, in the Pacific Island and Oriental Islands. Chapter 18 of the lengthy text tells the story of Delano's discovery of the wayward ship Tryal, originally captained by Don Benito Cereno $^{37}$, and Delano's slow recognition of the slave mutiny that had occurred on board. The chapter is itself a collection of Delano's own account, the account of one of his officers who maintained the log book, and a collection of documents - mainly depositions - taken from Delano, Cereno, and Delano's midshipman, Don Nathaniel Luther. Already a polyvocal text, the chapter is further complicated by the act of translation, as Delano notes:

My deposition and that of Mr. Luther, were communicated through a bad linguist, who could not speak the English language so well as I could the Spanish, Mr. Luther not having any knowledge of the Spanish language. The

37 In Delano's original text, Don Benito Cereno's first name is written as both "Bonito" and "Benito" while his last name is written as both "Sereno" and "Cereno." Since the only text from Cereno himself comes in translation, this discrepancy is assumed to be an error committed by Delano and the translators. For the sake of consistency, the more recognized spelling (thanks in large part to Melville's novella), "Benito Cereno," has been used throughout this chapter. 
Spanish captain's deposition, together with Mr. Luther's and my own, were translated into English again, as now inserted; having thus undergone two translations. (Delano 331)

Delano inserts the translations as they originally appeared into the closing pages of his narrative.

Delano is himself a confident, condescending, arrogant man and his narrative is unintentionally telling in terms of his own character and the state of race relations at the beginning of the nineteenth century. Delano opens his section of the narrative by noting that he and his crew had been at sea for a year and a half "and had not made enough to amount to twenty dollars for each of my people, who were all on shares, and our future prospects were not very flattering" (Delano 320). Delano also notes that many of his men defected in New Holland, and that they were replaced by criminal stowaways who "materially altered the quality of the crew" (320). To deal with the new men, Delano takes to "sometimes exercising very strict discipline, and giving them good wholesome floggings" (320).

Upon discovery of the drifting and wayward Tryal, Delano decides to board and notes as he approaches that the ship's "decks were filled with slaves" (322). Aboard the ship, he hears their stories of alleged storms and illnesses, long before he understands the true nature of the ship and its crew. Delano cites his good nature, invoked through pity, for his survival aboard the mutinous Tryal:

They all looked up to me as a benefactor; and as I was deceived in them, I did them every possible kindness. Had it been otherwise there is no doubt I should have fallen a victim to their power. It was to my great advantage, that, on this occasion, the temperament of my mind was unusually pleasant. The apparent sufferings of those about me had softened my feelings into sympathy; or, doubtless my interference with some of their transaction would have cost me my life. (Delano 323) 
And yet Delano does not remain soft-hearted throughout his visit or his subsequent narrative. He is critical of Spanish Captain Benito Cereno's handling of the ship, noting that "Several $[\ldots]$ instances of unruly conduct" by the slaves should have $[\ldots]$ demanded immediate resistance and punishment" but were instead "easily winked at, and passed over" by the delinquent captain (323-324). Cereno's constant companion, allegedly a slave but really a leader of the rebellion who remains close so as to protect his secret, also annoys Delano as he wonders why Cereno allows such "extraordinary liberty"; eventually, Delano "requested the captain to send him on deck" as to speak privately (324). Yet again, Delano is denied, something he attributes to the captain's weakness rather than perceiving the real issue at hand.

When Delano tries to leave the ship, Cereno jumps overboard, fleeing his captors. It is this moment that Delano becomes aware of the social drama unfolding before him, but this moment is not the origin of the social drama. Instead, the reader has to consider the actual original breach, something seemingly difficult to do in this narrative. In the cleanest sense, the mutiny aboard the slave ship can be seen as the original breach, the "units of aharmonic or disharmonic social process, arising in conflict situations" (Turner, The Anthropology 74). Using the mutiny as the breach itself clearly defines the immediate and subsequent crisis as the slaves and Spaniards take sides in the impending conflict. Delano's boarding of the ship causes the slaves to obfuscate the rift, but the rift itself remains. When Cereno physically breaches the ship and flees his captors, he alerts Delano to the drama playing out before them all, and re-engages the crisis and the required taking of sides. Indeed, Delano returns to his boat, opens fire on the Tryal, and attempts to pursue it. 
Cereno urges him to reconsider the pursuit, however, noting the "negros [sic] were such bravos and so desperate, that there would be no such thing as conquering them" (326). Delano responds to Cereno's request with barely veiled condescension and disgust: "I saw the man in the situation that I have seen others, frightened by his own shadow. This was probably owing to his having been effectually conquered and his spirits broken" (326). For Delano, there is an inherent weakness in Cereno that allows such a conquering, despite all evidence of the slaves' brutal attempts at achieving their freedom. It is clear that in this crisis, in this taking of sides, Delano is at once against the slaves and against Delano himself.

The ensuing fight between Delano's men and the slaves serves simultaneously as an ongoing moment of crisis (from the slaves' perspective) and an attempt at redress (from Delano's, Cereno's, and the dominant "white" perspective). Once the slaves are defeated, chained, and brought on land, the subsequent "trials" to which they are subjected also serve as a form of redress, albeit one perpetuated and controlled by the ruling class. In his narrative, Delano includes the official sentencing of the living mutineers. All the remaining men were condemned "to the common penalty of death, which shall be executed, by taking them out and dragging them from the prison, at the tail of a beast of burden" and then "they shall be hung until they are dead" (347). The first five executed were also decapitated and their heads "fixed on a pole" (347). This form of redress is also intended to serve as a form of resolution, one that reinforces existent social norms by an overt display of power meant to control those who may consider similar forms of resistance. Such a resolution is, as history has shown, distinctly problematic. Resolution ideally is intended to reintegrate the wayward section of society or allow for the "social recognition and legitimation of irreparable schism between the contesting parties" (Turner, The Anthropology 75); in this instance, neither of 
these goals is achieved, leaving the social drama volatile and barely subsumed, ripe to foment dissention anew. Without a resolution, with only the blatant display of power and no progress, society is left to consistently revisit (and revise) its standards and its understanding of competing factions. Such a process leads, as the works of Melville, Wright, and Lowell demonstrate, to the repeated revision of history itself.

This partial or failed resolution points to a larger problem in the narrative, and in the history from which it springs. The social drama of the mutiny is part of a larger social drama - the agon of race relations (in this case including the relationship of whites and all others, including those of Spanish and African descent) and the question of slavery in American history. This underlying social drama is harder to locate in Delano's narrative, but it is no less present. Thus, Delano sees only a weak (Spanish) captain, a weak (Spanish) crew, and a (black, human) cargo that needs to be punished and traded for any cash value still available. He never once refers to the slaves by name, despite the fact that his own officer and Cereno himself both do. Perhaps what is missing most from Delano's narrative is any mention of the slaves themselves, except in passing. Such an omission is an important one given that the mutiny and those behind it are (or at least should be) the driving force of the narrative itself.

The one exception to Delano's lack of attention to the slaves occurs when he describes boarding the ship after his crew has forcefully retaken command, over significant resistance:

On going on board the next morning with hand-cuffs, leg-irons, and shackled bolts, to secure the hands and feet of the negroes, the sight which presented itself to our view was truly horrid. They had got all the men who were living made fast, hands and feet, to the ring bolts in the deck; some of them had part of their bowels hanging out, and some with half their backs and thighs shaved 
off. This was done with our boarding lances, which were always kept exceedingly sharp, and as bright as a gentleman's sword. (326)

There is no intentional irony present when he comments on the shininess of the lances that dismembered and disemboweled other human beings. Delano does prevent the remaining members of the Tryal's original crew from continuing to injure "these wretched creatures" (326) but his own language speaks more to the benevolence offered an animal than it does to any understanding of the humanity on board. Indeed, were it not for the depositions of other participants, this animalistic commentary would be the last reference made regarding the slaves on board.

Delano focuses the rest of his narrative, before the inclusion of the depositions, on the ways Cereno tries to avoid paying him for the aid he rendered. Again, with seemingly no irony, Delano notes: "When I take a retrospective view of my life, I cannot find in my soul, that I ever have done any thing to deserve such misery and ingratitude as I have suffered at different periods, and in general, from the very persons to whom I have rendered the greatest services" (331). Delano's concern for his own pocketbook, paired with his lack of concern for human suffering, offers a clear view of one side of the slave question and race relations in the United States at the turn of the century. This dismissive attitude re-emerges at the close of the chapter as Delano, after detailing the sentences handed down to the living mutineers, turns to his own accomplishments again as he tells the reader he received a "polite letter" and a "gold medal" from the king of Spain for his efforts (350). He includes a copy of his return missive, where he notes, "The services rendered off the island St. Maria were from pure motives of humanity" (352). Delano's words are jarring in their contradiction to the text that 
immediately precedes them. It seems that the mutiny was not the only social drama to which Delano was blind.

It is Benito Cereno who offers the best understanding of the ship, the mutiny and the aftermath. In his deposition, which interrupts the narrative with its inclusion near the end of the chapter, Cereno notes that he "set sail with his ship from the port of Valparaiso, bound to that of Callao; loaded with the produce of the country, and seventy-two negroes of both sexes, and of all ages, belong to Don Alexandro Aranda" (333). Cereno notes the slaves by name when he can, listing their ages and other known details. Babo, who will recur in Melville, (slightly altered) in Wright, and in Lowell, is included in his list of those taken from Senegal; Delano also names the slave Atufal, who recurs in Melville and Lowell. Cereno states that "none wore fetters" at the request of Aranda, and they "revolted suddenly" one evening, killing eighteen men on deck (334).

Cereno lists Babo as the "ring leader," a fact Melville will use in his narrative, as will Wright and Lowell (335). Babo demands that the ship be returned to Senegal. Another slave by the name of Mure determines to kill Aranda in his sleep as the only means of ensuring their release from slavery. Stabbed in his bed, Aranda is thrown overboard "yet half alive and agonizing" (335). It is Mure, not Babo, who plays the part of constant servant to Cereno, refusing to allow him to speak to Delano alone when he boards, a fact altered by Melville (and subsequently by Wright and Lowell). Cereno notes that Babo is one of the slaves killed when Delano's men board the ship to take it back under control. Cereno offers no particular sympathy to the slaves, but he does recognize and name them as individuals, and he knows (and conveys) their motivations and outcomes. Cereno at least touches upon the possibility 
of the mutiny serving its part in a larger international social drama centered on the procurement and sale of human beings.

\section{From Delano's Narrative to Melville's Benito Cereno}

It is this underlying tension — the extended social drama surrounding slavery—present in Delano's narrative (seemingly without his knowledge) that spurs much of Melville's revision. Much of the story constructed by Melville should be familiar to those who have read Delano's text. Melville's novella tells the story of American ship captain Amasa Delano who encounters the San Dominick, captained by Don Benito Cereno, off the coast of Chile in 1799. Noticing that the ship "showed no colors" and was "drawing too near the land," Delano assumes the ship is in distress and takes his whale-boat to investigate (Melville 162). Upon boarding, Delano "was at once surrounded by a clamorous throng of whites and blacks, but the latter outnumbering the former more than could have been expected," and is told an elaborate "tale of suffering," including scurvy, fever, and narrowly escaped shipwreck that leave the crew and slaves aboard decimated (Melville 165).

Much of Melville's tale centers on Delano's suspicions of Cereno, driven by Cereno's behavior and racial/ethnic identity, and the resulting delay in learning the ship's true history. Cereno, who never appears without his slave/servant, Babo, strikes Delano as a capricious captain - at times seemingly harsh and at times unbelievably lax with his crew. What Delano does not suspect, however, is the actual truth, that there has been a slave mutiny aboard that results in the murder of most of the crew. Babo is not Cereno's servant, but rather his keeper, staying with him at all times to prevent him from revealing the truth. Cereno jumps into Delano's whaleboat when he prepares to return to his own ship, revealing the truth, and leading to a battle in which Delano's crew overtakes the San Dominick. Sentenced to death 
for his offenses, Babo is quickly followed in death by Cereno, inextricably linking the two in life and death in a way never fully explained by Melville.

Plagiarism and Play

Benito Cereno relies heavily on Delano's chapter eighteen. Despite the novella's 1855 publication, however, it was not until 1928 that Harold Scudder discovered Melville's source material. Since that discovery, critics have explored repeatedly the importance and influence of the original text, a point that deserves some consideration before proceeding further into the relationship between the texts. Scudder himself declared, "I discovered the interesting fact that in Chapter XVIII of Captain Delano's book Melville found his story ready made. He merely rewrote this Chapter including a portion of one of the legal documents there appended, suppressing a few items, and making some small additions" (502). And yet, Scudder also does not "wish, however, to accuse Melville of plagiarism," noting that the "apparently trifling differences [made by Melville] very materially alter the tone of the narrative" (529). Scudder's language, however, certainly introduces (and suggests) the problem of authenticity and originality in these revisions.

Shari Goldberg agrees that "Melville's doubling is virtually unrestricted —at points he reprises sentences, paragraphs, and even whole passages from his 'original,'” (6-7) but she disagrees with Scudder's basic premise of "ready made" storytelling:

His 'source text' is far from coherent or determinate: it is, rather, a compilation of variously authored writings attesting to a series of events and collected under the general title 'A Narrative.' Delano's 'original' already reads as a rewriting insofar as it gathers several accounts and types of writing, and as such it not only contains 'tensions and gaps' but occasionally contradictory bits of information. What Scudder proclaimed as critical bedrock was, in effect, that Melville chose as his subject not a series of known events, but a text that already exposed the divergence between 'history' as it occurred and the writing that later recorded it. (Goldberg 6) 
Goldberg, however, goes too far in her "defense" of Melville, just as Scudder goes too far in his attempts to join the "many academics [who] establish scholarly reputations through demonstrating skill at source hunting" (Rosenthal A14). In reality, Melville's revisions are closer to the original than Goldberg allows, and yet not nearly as close as Scudder insists.

Melville does not simply add "trifling differences" to achieve a stronger effect. And yet, Delano's piece certainly is the bedrock—the foundational moment—for Melville. Melville's works both use the same names for major characters, the same use of legal documents towards the end of the narrative, the same limited vision available through Delano's clouded understanding of the ship's history, and the same major plot points and developments.

What Scudder, Goldberg, and other critics highlight is a problem inherent to the concept of revision. Unlike Williams, Miller, and Baldwin, the writers and playwrights discussed in this chapter (and the next) rely on earlier narratives rather than historical moments as a foundation for their work. Thus, as Miller, Williams and Baldwin may be called to task for their lack of originality in terms of subject matter, or for altering the historical record too little or too much, they are not generally operating under the specter of false art or even plagiarism. That Scudder has to express his "wish" not to "accuse Melville of plagiarism" means that the proverbial elephant—-the specter of plagiarism—is already present in the room (529).

Victor Turner gives us, albeit indirectly and unintentionally, an innovative way of approaching the dilemma of originality, particularly in regards to art, one not already put forth in justifications of intertextuality, translation, satire, parody, or revision. Discussing the need for and the role of the ritual and the aesthetic, he argues: 
The antistructural liminality provided in the cores of ritual and aesthetic forms represents the reflexivity of the social process, wherein society becomes at once subject and direct object; it represents also its subjunctive mood, where suppositions, desires, hypotheses, possibilities, and so forth, all become legitimate. We have been too prone to think, in static terms, that cultural superstructures are passive mirrors, mere reflections of substructural productive modes and relations or of the political processes that enforce the dominance of the productively privileged. If we were as dialectical as we claim to be, we would see that it is more a matter of an existential bending back upon ourselves: the same plural subject is the active superstructure that assesses the substructural and structural modalities that we also are. Our concreteness, our sustainability is with us in our reflexivity, even in the ludic play domain of certain of our liminal moments: play is more serious than we, the inheritors of Western Puritanism, have thought. (original emphasis; foreword, The Ritual Process vii-viii)

Melville, Wright, Lowell and, in the next chapter, Hansberry, all use the revision as a means of operating within the "ludic play domain." Part of the act of revision is the act of play in terms of its existence outside the necessary and the quotidian, but also in terms of its "attempt to achieve or gain something," its "freedom or room for movement" (OED; play, n). For these writers, the act of revision is the ability to criticize, to highlight, and to make space within a pre-existing structure. For Melville, it is the ability to generate room for dissent in history, or more specifically, in how the historical is represented, and what is chosen to be seen and to be ignored. Thus, revision-as-play is not meant to be revision-as-playful, but rather, the ability to see both the structure and the substructure: to see what is and what can be.

Melville generates this room for play via the changes he makes in the original narrative; put another way, it is the liminal that generates this room. The overlap of the original narrative and the new narrative creates a moment "when the past is momentarily negated, suspended, or abrogated, and the future has not yet begun, an instant of pure potentiality when everything, as it were, trembles in the balance" (Turner, From Ritual 44). 
The liminal is the briefest moment of potentiality. Thus, what appears to be a simple act of revision — a resisting of the primacy of Delano's original—is in fact Melville's complicated process of creating new (and resisting pre-existing) meaning.

Melville's Revisions

The changes Melville makes, then, allow the reader to focus in on what he wishes to challenge, highlight, and exclude. ${ }^{38}$ Some of the smaller details changed by Melville seem to suggest a desire to add an anti-slavery stance to Delano's original narrative which, if not proslavery, is at least supportive of the status quo. One of the subtlest changes Melville makes is altering the date of the mutiny. In Delano's narrative, Cereno's ship, the Tryal, was captured in 1805 (it originally left port in 1799). Melville's story is set in 1799. Some critics have argued that he failed to note the difference in dates when reading the original, but others have argued that he set the date back intentionally, which seems more likely given Melville's overall close attention to the original manuscript. Will Slocombe argues that pushing back the date of the mutiny makes "Babo's rule [...] contemporaneous with Toussaint L'Ouverture's rule on San Domingo" (26-27), thus placing Babo's coup alongside “the successful bloody rebellion of the slaves of San Domingo, a topic of great antebellum interest" (qtd. in Slocombe 27). By altering the date, Melville places the text in the heart of the slavery debate and aligns the mutiny with another uprising, thus demonstrating an international push against human bondage.

Melville also changes the names of both ships, an apparently less subtle decision. He changes the name of the American ship from the Perseverance to the Bachelor's Delight,

\footnotetext{
${ }^{38}$ Given that Delano's original text of "about 14,000" words becomes Melville's novella of "about 34,000 words," it is clear that Melville expanded and altered much more than he cut (Putzel 197).
} 
moving from a ship that sounds virtuous to one that sounds rather less so. Max Putzel draws connections to the "sexual associations bachelorhood had for Melville" as found in his "Paradise of Bachelors and Tartarus of Maids" (199). While the overtly sexual is not present in Benito Cereno (aside from references to the female slaves who are referred to in animalistic terms rather than sexual ones), male virility, power and prowess certainly abounds. More importantly, moving from a term often associated with overcoming obstacles and remaining steadfast to a set of terms sometimes associated with capricious revelry indicates at best a critique of Delano and his crew. Indeed, given the behavior of the actual Delano already discussed in this chapter, the new name becomes more condemnation than critique.

Melville also alters the name of the ship Delano overtakes, as the Tryal becomes the much more clearly Spanish-sounding San Dominick. ${ }^{39}$ In doing so, Melville is able to heighten the tension between Delano and Cereno and display Delano's distrust of all others in the text. Putzel argues that the stronger Spanish presence serves as a counterbalance to the American zeal and vigor, instead standing in for "the old order, a feudal structure of caste and fealty fast losing its hold" (194). Slocombe sees this renaming as one of many ways Melville emphasizes references to "Catholicism and Spain" as a way, again, of highlighting the differences between the ships and the nations (26). In a novella struggling to grapple with the question of slavery, such a comparison between the "old world" and "the new world" certainly stresses national and international tensions.

\footnotetext{
${ }^{39}$ Again, as Jesse Schotter notes, the name also serves to "invoke the San Domingo slave revolt" (65).
} 
The increased presence of Benito Cereno (both literally in terms of numbers of appearances and figuratively in terms of amount of detail) throughout Melville's text further exacerbates the presence of Spain and the old world in the text or, more accurately, a negative stereotype of Spain and the old world. ${ }^{40}$ While Cereno is certainly not glorified in Delano's original text, what was a personal frustration tinged by racist overtones here becomes a full-blown anti-Spanish diatribe. Cereno, for Melville, is both the "capricious commander" and the "pale invalid" $(206 ; 186)$. He is the "alternations of courtesy and illbreeding," the hardly masculine possessor of the "slender sword" and the seemingly feminine chameleon ${ }^{41}$ whose "velvets" were "but the silky paw to his fangs" $(185 ; 176 ; 186)$. Cereno is simultaneously masculine and emasculated, strong and weak, yet he is also black and white (or perhaps better stated-- neither black nor white). As María DeGuzmán illustrates, Cereno, as a Spaniard, 'is not only 'blackened' temperamentally ('saturnine,' 'hypochondriac,' 'moody,' 'despotic'), but, moreover, physically marked as non-Anglo or nonwhite in accordance with the transmutation of the Black Legend into nineteenth-century racial discourse" (61). While Dana Nelson sees Cereno as one of the "whites" who must "blind themselves to large portions of their experience if they are to maintain their sense of

\footnotetext{
${ }^{40}$ Putzel argues Benito Cereno becomes "the central character" of Melville's text for many reasons, including the naming of the text itself (whereas Delano is clearly the star of his own text) (Putzel 200).

${ }^{41}$ This feminizing of the "other" is not uncommon, as Robyn Wiegman notes in terms of the relationship between women and blacks:
}

By figuring blackness as a feminine racial formation, the possibility of the African(-American) male assuming an equal position with the crusader for advanced civilization, the white male, was thwarted and racial hierarchies became further entrenched according to the corporeal inequalities inscribed by sexual difference. (55) 
dominance," it becomes increasingly clear that Cereno is, if not black or "off-white" himself, inextricably tied to blackness (113).

Melville's Delano sees Cereno as more closely tied to the "filial or fraternal acts" shared with his black "servant," Babo, than to his white "brother captain" (Melville 169). He is guilty of running the "unmanageable ship," which, while physically blown off track, is metaphorically led astray by the inappropriate handling of (and mingling of) blacks and whites who both move freely on the ship, even before the mutiny (Melville 174). Although Cereno has "white lips," his face is dominated by a "resentful [black] shadow" (Melville 182). But it is the end Melville contrives for Cereno that seems to seal his fate even more so than any other details. Unlike in the original narrative, Cereno does not survive his ordeal. Instead, upon the death of Babo, his servant, he "follow[s] his leader" to the grave (Melville 258).

Whiteness and Blackness

In order to situate Cereno between the poles of black and white, Melville must establish his definitions of whiteness and blackness-Delano and Babo. While it is not difficult to read between the lines in Delano's original text to find a man capable of capriciousness and oblivion, Melville does not require even this level of reading comprehension from his audience. Melville's Delano is "a fool" who, while attempting to provide for the basic needs of those aboard the San Dominick, "cannot minister to their spiritual agonies, or even understand them" (Vanderhaar $181 ; 185)$. He is at once the bearer of benevolence and blindness, of condolences and criticism. Within one breath, he moves from "surprise" to "pity, both for the Spaniards and blacks" to the feeling that "had Benito Cereno been a man of greater energy, misrule would hardly have come to the present pass" 
(Melville 168). Delano both praises the blacks--“Don Benito, I envy you such a friend; slave I cannot call him" - and degrades them: "Captain Delano took to negroes, not philanthropically, but genially, just as other men to Newfoundland dogs" (Melville 176; 213). He alternates between complete acceptance of the situation at hand and distrust—but his distrust is always aimed at the wrong parties. In fact, it is not the blacks who are "too stupid," but rather Delano who, despite all evidence, cannot see the truth before him (Melville 201). Margaret M. Vanderhaar elaborates: "Despite his innocence, he seems to sin by omission, by choosing not to understand the terrible drama being played out before his eyes" (185). For Vanderhaar then, Delano's blindness—-like his racism—is not inherent, but a choice. Such a reading suggests that other Americans who either approve of or fail to form an opinion against slavery are, for Melville, equally blind.

Certainly many have read the new Delano as simply an exacerbation of the original, for better or for worse. ${ }^{42}$ Others, however, in attempting to draw out the at-times subtle views on slavery present in the text, read Delano as a more complicated representative of America's contradictory views on slavery at the time. Such readings place Melville appropriately in stage three-redressive means — of Turner's construct of social drama. Slocombe notes that Melville, "By locating Delano as a Northerner" in the opening lines of his novella, is "ostensibly linking him to the emancipation of slaves by geographical location, while at the same time using Benito Cereno to demonstrate Delano's inherent racial prejudices" in an attempt to clearly demonstrate "the ideological distance between

\footnotetext{
${ }^{42}$ Putzel argues: "To some extent Melville makes Delano his tragic hero, who catches a glint of reality like a jewel mysteriously sparkling on the bosom of a Spanish sailor and sees nothing more" (193). This description of Delano is not an uncommon one as critics seem to vacillate between straight fool and romantic/tragic hero in their characterizations of Melville's troubled sailor. Neither, however, seems sufficient as Melville is clearly more critical and more nuanced in his view of all these characters.
} 
assumption and reality in the then ongoing race debate" (32). Thus, just being a Northerner does not eliminate Delano's prejudices against Spanish Cereno or the black slaves. Indeed, as Joshua Leslie and Sterling Stuckey note:

In spite of all Captain Delano's apparent warmth and generosity toward Negroes, he had not one micro-second of hesitation in using all his means to re-enslave them. Nor did he have any moral or ethical problem in proposing to purchase one of Don Benito's slaves. Unable to imagine Africans capable of subtlety of even of guile, he found his assumptions put to a severe test when he encounters Babo, the gifted and confident leader of the blacks on board the slave ship. (291)

What was a character flaw (or flaws) in the real-life Delano becomes the symbol of whiteness in Benito Cereno - one complicated by a compulsion for racism, a hunger for (retaining) power, and a blindness to all that does not serve a fixed vision of the world.

Opposite (white) Delano rests (black) Babo. Babo is one of the original slaves aboard the Tryal, and he is one of the ringleaders of the mutiny; however, he shares this leadership role with a slave named Mure, as noted earlier. It is Mure in the historical account who serves as constant companion to Cereno, and it is Mure who escapes death aboard the ship to be tried (and executed) once reaching port. Babo, in the original narrative, dies in the fight that ensues when Delano's crew retakes the ship from the mutineers. It seems safe to assume that Melville found concentrating the leadership role into one character clearer for the reader where each character comes to represent a greater idea or type. The name Babo, with its alliteration, does have a stronger sound than Mure. Some critics felt it was meant to be reminiscent of baboon, or Bab-ed-Din, "a Persian religious fanatic" with whom Babo shared "the instigation of an insurrection and his own execution" (qtd. in Cochran 217; Cochran 218). It is important to stress, however, that critics have associated these negative feeling 
toward blacks with Melville, noting that he "wanted the primitivistic associations" (original emphasis; qtd. in Cochran 217) and he "intended to praise them" (Cochran 217).

Thus Babo, while having a clear reason for mutiny — and possibly even a justification for murder-remains decidedly unsympathetic in Melville's text. By all rights, in order to produce a clearly anti-slavery text, Babo should evoke either sympathy or empathy. Yet Melville changes the original text significantly to add cruelty to Babo. Although the original slaveholder, Don Alexandro Aranda, is killed in the original narrative (he is stabbed and thrown overboard while still alive), Melville increases the brutality surrounding his death. He is stabbed in his berth and "dragged [...] on deck," but Babo stops them from throwing him overboard "bidding the murder be completed on the deck before him" (Melville 244). His body is dragged back below and Cereno is left to ponder his fate for several days. When Cereno asks after the body in order to ensure it is "preserved for internment ashore," he is shown “a skeleton, which had been substituted for the ship's proper figure-head - the image of Christopher Colon, the discoverer of the New World" (Melville 245). The skeleton belongs to Aranda and Babo uses it as a visual reminder to the remaining Spanish crewmembers: "'Keep faith with the blacks from here to Senegal, or you shall in spirit, as now in body, follow your leader,' pointing to the prow" (Melville 245). In the end, however, as previously noted, Cereno follows Babo — not Aranda - to the grave, beholden to his "servant" until the end.

Melville adds an additional scene meant to highlight Babo's menacing nature. While escorting Cereno around the ship to ensure he does not alert Delano to the mutiny, Babo reveals their daily activity: Babo's shaving of Cereno's face and neck. Delano perceives this discovery as evidence of "his host's capriciousness" and notes his "servant's anxious 
fidelity" (Melville 210). In reality, Babo uses the ritual as a means of dragging a blade across Cereno's throat, reminding him of his perilous, and subservient, position. Indeed, even Delano cannot miss the symbolism (even if he quickly dismisses it): "Altogether the scene was somewhat peculiar, at least to Captain Delano, nor, as he saw the two thus postured, could he resist the vagary, that in the black he saw a headsman, and in the white a man at the block" (Melville 214). When Cereno begins to shake under the hands and blade of Babo, Babo draws blood: "No sword drawn before James the First of England, no assassination in that timid King's presence, could have produced a more terrified aspect than was now presented by Don Benito" (Melville 215). While the reader and Delano initially may miss the implications, they become clear once the mutiny is revealed. ${ }^{43}$ Binaries and Borderlands

Melville pushes his three main characters - Cereno, Delano, and Babo — into flat stereotypes; indeed, he pushes them into members of a black/white binary. As such, they are "assumed to possess all the characteristics of that category, good and bad" (Espinoza 17). If Delano is white, then not only does he assume the "good and bad" characteristics of whiteness—-dominance, control, violence, "racial purity” (DeGuzmán xxiv)—he also becomes defined in "opposition to another category": blackness (Espinoza 17). Babo comes to represent blackness and therefore lacks dominance, control and "racial purity" but possesses violence (just as do the whites), along with anger, mystery, and the powers of manipulation. Cereno, neither black nor white, is defined as opposed to both categories. He becomes, in a sense, an exile from the known.

\footnotetext{
${ }^{43}$ This scene is pivotal for Richard Wright; it is this scene that seemingly inspires the central scene of his revision, Man, God Ain't Like That.
} 
Allan Moore Emery disagrees with this bifurcation along racial lines in the text, arguing instead for a wider view of Babo (and perhaps, subsequently, of all the characters in Melville's text):

Whatever Babo may represent for the Spanish captain, he was obviously meant to typify the 'malign' potential in every man. 'Snakishly writhing up' from the bottom of Delano's boat [...] he is far more than a homicidal black: He is the devilish symbol of all the depravity - black, white, male, female - to be found aboard the San Dominick. Cereno's private fixation should not obscure Melville's 'larger' point. In 'Benito Cereno,' 'the negro' stands for all mankind. (330-331)

And yet, this reading is far too modern. Melville would have been quite aware-given his interest in and disapproval of slavery - that Babo's construction as a black man and as an African slave would have predetermined how his manipulation and violence would be interpreted by the majority of white readers. Babo was not likely to be read as "all mankind," but rather a compilation of "metaphorical shortcuts" able of producing "notions of excessive, limitless love, anarchy, or routine dread"-and Babo certainly does not represent love in Melville's text (Morrison x).

The reader's feeling of being dislodged, awash in a sea of binaries, stereotypes, and violence, is seemingly quite intentional and is heightened by the dominant setting of the novella. To use Gloria Anzaldúa's ${ }^{44}$ term, the San Dominick is a "borderland," a place where "two cultures edge each other, where people of different races occupy the same territory, where under, lower, middle and upper classes touch, where the space between two individuals shrinks with intimacy" (preface). As such, this borderland is neither white nor

\footnotetext{
${ }^{44}$ Given Melville's clear choice to emphasize both blackness and the non-black/non-white Spanish other, his text can be opened up to multiple forms of critical theory, including African American and Latino/a theories - hence the incorporation of Latina author/theorist Gloria Anzaldúa.
} 
black, rich nor poor, clear nor obfuscated. It is in a constant state of transition and renegotiation. The reader is placed between multiple worlds and must find a safe place to analyze this text, this "herida abierta": "where the Third World grates against the first and bleeds" (Anzaldúa 25). This borderland is an "unnatural boundary," but it is also its own location as "the lifeblood of two worlds" are "merging to form a third country" (Anzaldúa 25). The reader is set adrift on this borderland without a map or a guide. The borderland comes to represent a type of negative liminality where the only possibilities available appear negative or vexed.

What remains, then, is a biased/blinded Delano, a manipulative/unsympathetic Babo, and a weak/capricious Cereno. What the characters all share is the capacity for violence. Cereno supports slavery; Delano too supports slavery, degrades blacks and orders the attack on the San Dominick; Babo and his fellow slaves aboard the ship, both male and female, are mutineers and murderers. Violence begets violence in the text and the binary begins to slip. Anzaldúa suggests that the violence of the oppressor dictates the violence of the oppressed: "But it is not enough to stand on the opposite river bank, shouting questions, challenging patriarchal, white conventions. A counterstance locks one into a duel of oppressor and oppressed; locked in mortal combat, like the cop and the criminal, both are reduced to a common denominator of violence" (100). It is a thought supported by fiction writer Leslie Marmon Silko when she iterates "all slaves dreamed of becoming masters more cruel than their own masters" (qtd. in Barnett and Thorson 161). The reader thus becomes immersed in a sea of viciousness, where each act of violence can be traced back to another act of violence, which is indeed the reflection of more historical violence. This cycle of violence, Girard tells us, is predictable, as "Violence is supremely mimetic," and the struggle for resources 
(including freedom and equality) begets and triggers additional struggle "as the antagonists who desire the same object keep thwarting each other and desiring the object all the more" (Girard, "Mimesis and Violence" 12-13).

But, if all are violent and "indicative of a global depravity" (Emery 317), whom is the reader to trust? What is, as many have questioned, the real moral of this story? Why has Melville revised a polyvocal text while still withholding a clear, central voice of reason? How can Melville be participating in redressive means, meant to "constitute the plural 'selfknowledge' of a group" (Turner, The Anthropology 42), and meant to replace or replicate or reform the jural, when his reader is left with no solid footing?

Redress?

In order to make sense of Melville's text—and in particular, in order to find the redressive means therein - it is important to view this text as an assertion of the absurd, the contradictory, and the failure inherent to our own history. That assertion does not, it seems, offer a clear solution, contrary to what many critics have postulated. Darryl Hattenhauer claims that Cereno, "As the representative of the Old World, [...] emerges as that which America's upward mobility through outward expansion will surmount" while Babo, "as the representative of the Third World [...] emerges as that which America will displace" (16).. Vanderhaar summarizes earlier views on Benito Cereno, including Allen Guttman's belief that "Melville was portraying a heroic although unsuccessful revolt with which he heartily sympathized," Guttman and Joseph Schiffman's claims that "Babo is really the martyr-hero or the moral victor in the story," Sidney Kaplan's assertion that Melville was "giving his public in 1855 a piece which re-enforced every pro-slavery idea they might hold," and many more (Vanderhaar 181). All of these large assertions fall flat when faced with Melville's 
own lack of distinct moral assertions, his failure to provide a coherent and reliable narrator or character, and the overall violence and depravity that seeps through the text.

Instead, Melville offers up the idea that humanity itself has failed —on all levels—-for all participants. All are violent; all are troubled. There is no clear exit strategy. "Benito Cereno is not a narrative about redemption, but damnation," as Slocombe argues (32). Melville leaves "Gordian knots," like the man aboard the San Dominick, "For some one else to undo" (Melville 202). This is not a text of answers, but rather one of destruction: the narrative itself is fractured, the characters are all flat types riddled with violence, the story is both old and new, the location is a borderland (or borderless).

Goldberg addresses these ideas, viewing Melville's text as one that explores the power of silence:

As the only Melville text to deal explicitly with the morality of the slave trade, its inclusiveness seems to politicize and historicize silence as at once part of narrative and exceptionally difficult to narrate. The experiences of those devastated by slavery were silenced, and so subsist in the silences of American history; to address these gaps without collapsing them as 'quiet ends' is to approach apparent absence as essential context. (Goldberg 1-2)

She notes that the Fugitive Slave Act passed five years before Melville's text "and its silencing effects were, as Melville composed, becoming increasingly evident" (Goldberg 7). She argues, "it would not be inaccurate to propose that juridical silence is as much the historical referent of the text as Delano's Narrative. Melville's text may be understood to represent justice's perversion as an archive of silence, empty of the content it is expected to hold" (Goldberg 7). Put another way, Melville can be seen as placing a mirror up against both history and contemporary society, generating the liminal: "a time and place of withdrawal from normal modes of social action, $[\ldots]$ a period of scrutinization of the central values and axioms of the culture in which it occurs" (Turner, The Ritual Process 167). The 
liminal is not a comfortable place to be, but it is part of the redressive process. It is the examination before the rebuilding. Melville thus leaves us with all of the questions, and none of the answers. It is the reader's role to take up the knot, to make sense of the types, to grapple with the violence, and to come to terms with the other, however s/he envisions it. The reader must determine how to find a "tolerance for contradictions" amidst the rubble of literature and history (Anzaldúa 101).

\section{Defining the Past, Understanding the Present II: Herman Melville and Richard Wright}

If Melville's text is a question, Wright's Man, God Ain't Like That... is an answer, but not one that is any more comfortable to hear. Wright's text offers characters who are no less flat and typed; he uses airplanes, multiple locations, and ex-pats to replace a ship at sea; his text was originally meant to be heard as a radio play and thus is written entirely in dialogue, leaving the reader without important context, just as in Benito Cereno. But where Melville assigns violence to us all, Wright offers one momentarily violent black character who is clearly and undeniably shaped by the ongoing perpetuation of violence by the white man.

\section{Play Summary, Production History, and Critical Reception}

Wright's play recounts the story of two white American ex-pats living in Paris, John and Elise, husband and wife, who, while traveling in Africa, literally run over an African man named Babu. After taking him for help, all the while declaring, "You can't hurt these monkeys," John and Elise decide to "keep" Babu as a servant and bring him to Paris (Wright, Man, God 165). Babu is portrayed as willing, unintelligent, and possessed by his native, "primitive" religion, a religion that involves animal sacrifice (which John finds amusing and Elise finds disturbing). 
Upon arriving in Paris, Babu immediately disappears. Later, the listener/reader learns that he has been wandering the streets of Paris, attempting to understand why the "Black man live in mud hut in jungle" while the "White man live in stone building in city" (Wright, Man, God 177). In his wanderings, Babu encounters a painting of John, himself an artist, in which John posed as a Christ-figure. Babu, who has been learning about Christianity through a mission Church in Africa, mistakes John for the actual Christ. Interpreting Christianity via his own limited understanding of Christianity combined with his native religion, he deduces that the white man killed Christ the first time and subsequently was blessed. Therefore, he returns to John, confronts him as Christ, and violently beheads him in the belief that John, as Christ, will come back and bless the black man: "Now it's the black man's turn!” (original emphasis; Wright, Man, God 189). The police, unconvinced that Babu is smart or diabolical enough to commit such a crime, release him and accuse John's mistresses of the murder. Babu returns to Africa where he organizes "a new religious cult" centered on his belief that "his erstwhile master will rise like Jesus from the dead" (Wright, Man, God 182).

Man, God has received very little criticism since its first appearance. The work, currently published in Wright's Eight Men, began as a radio play commissioned by a German radio station (Bradley xxii). This fact seems to have been overlooked by most reviewers and critics. Saunders Redding, in his 1961 review of Eight Men, writes: "character is sketchy and plot implausible, it takes more than dialogue to establish a compelling motive for ritual murder" (135). Raman Singh also notes, "Artistically, the story is weak, but it shows that Wright was experimenting with his material. The story is told entirely through dialogue; this accounts for some awkward moments in transition from Africa to Paris" (104). Clearly, these reviewers have failed to "read" the story as something meant to be heard. 
Russell Carl Brignano offers a slightly more positive reading of the play, complete with an understanding of the original form, arguing that the work represents a shift in Wright's writing:

'Man, God Ain't Like That...' is thus a mixture of the serious, the comic, and the absurd. Bloodshed is not spared, as Babu hacks away at John in the process of beheading him. Behind the story seems to be an intelligence almost playfully humorous. Wright seems to be laughing, but not cynically, at the absurd travesties man has allowed himself to be a party to, if not the cause of. Like 'Man of All Work,' this radio script is a sign that Wright possessed some talent for working in dramatic genres to project tragically ironic materials into the area of the objectively comical. (169-170)

I would argue, however, that Wright's intelligence is not debatable and his work is most certainly cynical—and undeniably critical.

To see that cynicism and criticism, however, it helps to read this radio play as a revision, something critics have failed to do previously. Critics have linked Melville and Wright in regards to Wright's other works. Elizabeth Schultz notes that Wright read Melville's Moby-Dick: "Wright asserts that, along with metamorphosis, Ulysses, and The Sound and the Fury, Moby-Dick was his favorite novel" (640). Schultz argues that Wright relied heavily on Moby-Dick in his writing of Native Son; I argue that Wright undeniably wrote Man, God as a modern interpretation of Benito Cereno and this reading becomes one of the only ways to free Wright's radio play from accusations of artlessness and implausibility.

The Animalistic and the Primitive

Wright's play begins with John and Elise traveling through an unidentified location in Africa. John and Elise, like Melville's Delano, are untrustworthy narrators who see through distinctly biased (American) eyes and who view the African as animal. For Delano, blacks were "doe[s]" (198), "leopardesses" (198), "Newfoundland dogs" (213), and "wolf-like" 
(237) "cawing crows escaped from the hand of the fowler" (234) who were capable of "snakishly writhing" (233). For John and Elise, they are "some wild animal[s]" (155), "monkeys" (165) and "baboon[s]" (166). John and Elise exert a distorted benevolence toward the African, much as Delano does when he initially pities the men and women aboard the San Dominick. John literally hits Babu with his car and when they stop to help, they find him with a "gashed" head and bleeding "like a stuck pig" (yet another animalistic reference) (Wright, Man, God 157, 158). But John's sympathy is riddled, like Delano's, with condescension as he assures Elise that "You can't hurt these monkeys" (Wright, Man, God 157). Later, when Babu passes out on the way to the doctor, John has to find his pulse when Elise fails because, as John states, she "Never felt for a nigger's pulse before" (Wright, Man, God 159).

Babu, whose name is clearly meant to invoke Melville's Babo, does little to improve John and Elise's original perceptions. Unlike Wright's Babo, who is obsequious in order to disarm Delano, Babu is obsequious, completely beholden to John. Babu apologizes for having been hit, "So sorry my head hurt Massa's car" (Man, God 157) and for bleeding, “Massa, my blood's dirtying up your fine car" (Wright, Man, God 158). John and Elise take Babu to the "juju man" (Wright, Man, God 159) rather than to a hospital ("They'd report us to the police. There'd be complications") (Wright, Man, God 160), and then ultimately decide to take him home with them — as a servant. Babu readily submits to cleaning and cooking for the couple, and posing for John's art, in order to "Pay Massa back" (Wright, Man, God 160) for the expense of the ten stitches he received. Indeed, Babu sees this opportunity as a blessing as his "blood make sacrifice to Massa and Massa ask Babu to work. Babu then buy chickens and cut chickens' throat and let blood run to Babu's dead papa to say 
thanks to God. Babu bless Massa with blood" (Wright, Man, God 170). Babo uses the razor to draw blood on Cereno, using it to serve as a threat of large-scale bloodshed in order to control the ship and its "captain"; Babu uses blood as sacrifice and reverence. John is overjoyed with his servant: "I got a whole, live nigger to look after..." (Wright, Man, God 160).

John and Elise, like Delano, are blinded by Africa and the African, as well as by their own naivety. They romanticize the "tom-toms" (Wright, Man, God 155) they hear, but these drums do not represent Langston Hughes's “eternal tom-tom beating in the Negro soul- the tom-tom of revolt against weariness in a white world" (Hughes, "The Negro Artist"). They are instead, for John and Elise, a representation of the weaker race, a race whose "savages think we're gods"45 (Wright, Man, God 164). John and Elise, like Delano, see the other as exciting but controllable, a completely known entity. This definition is supported by Latina critic Debra Castillo's understanding of the other: "Anglo culture has a propensity not only to stereotype the Other's outcast alterity, but to fetishize it as exotic and attractive in contrast with Anglo America's own blankness" (7). Homi Bhabha sees the concept of the other as closely linked to the act of colonization: "Therefore, despite the 'play' in the colonial system which is crucial to its exercise of power, colonial discourse produces the colonized as a social reality which is at once an 'other' and yet entirely knowable and visible" (Bhabha 101). Thus, Melville's Delano cannot imagine that Babo is capable of mutiny because it suggests an unknowable other, an idea he finds incomprehensible; John and Elise suffer (John quite literally) from the same error.

\footnotetext{
${ }^{45}$ A brief comment that, upon rereading the revision, proves to be both explicit racism and explicit foreshadowing.
} 
Delano goes so far as to try to purchase Babo from Cereno as he "wishes to take over the slave from the Spaniard, but in his moral blindness he undervalues the 'merchandise.' He does not know that he wishes to bring a snake into Eden, and he thought the Negros too stupid to hatch any malevolent plans" (Vanderhaar 191). John and Elise "succeed" where Delano fails. They decide to keep their servant, taking him back to Paris. Elise urges John to "Paint ‘im John! Make ‘im pay his way, pose for you!" (Wright, Man, God 168). John is all too happy to play the role of master, and all too happy to infantilize his new follower: "Leaders know that they must treat those who follow them like children; they must always inspire imitation" (Girard, The Scapegoat 153). Babu thus becomes both servant and object, that which is commanded, seen, painted, and represented in only one dimension ("But when the sun's full in your face, I see the real color of your skin. It's strange [....] and red and blue and green and yellow...”) (Wright, Man, God 160). Like Delano, John and Elise will pay the price for their failure to see beyond the singular dimension, for their failure to see beyond that which is "entirely knowable and visible" (Bhabha 101).

\section{Mutiny}

Babu's "mutiny" is hinted at throughout the play, just as Babo's is in Benito Cereno, but it is no less shocking in the revision than it is in the original, particularly because Wright grounds this mutiny in the Christian faith. Babu is, from the beginning, a confused mix of “juju” or "jungle religion" (Wright, Man, God 170) and a form of Christianity that he learns in his "Mission church" (Wright, Man, God 166). Elise is fearful of bringing Babu to Paris because "His religion makes me shudder" (Wright, Man, God 165) but John assures her that he will "cure 'im of that" (Wright, Man, God 165). Babu carries his father's bones with him to Paris in a suitcase, along with "his robes, a bottle of palm wine, a Bible, hymn books, and 
a big knife" (Wright Man, God 171-172) in the ultimate combination of religions and foreshadowing.

Babu is a self-declared Christian by the end, and he renounces his "juju," but it is certainly not the "cure" John intended or the Christianity with which the reader would likely be familiar. Instead, Babu slowly begins to absorb his own version of Christianity, asking John if "There is one God for everybody, Massa?" (Wright, Man, God 166) and further demanding to know if "He white, Massa?" (Wright, Man, God 166). Babu uses the cues around him, noting the "Sunday school book show God white, Massa" (Wright, Man, God 166) and determining that despite John's claim that “yellow folks say God's yellow; black folks say He's black; brown folks say He's brown; and white folks say he's white..." (Wright, Man, God 166), God must be white because "White God powerful. He let white man fly" in airplanes (Wright, Man, God 166).

Wandering through the streets of Paris after becoming separated from John and Elise upon landing, Babu attempts to reconcile the "white man's jungle" of buildings and technology with his own understanding of Africa (Wright, Man, God 175). Seeing Paris as the "white man's Heaven," Babu is determined to bring salvation and resurrection to Africa (Wright, Man, God 175). He has internalized the white man's belief that the white man has been divinely favored above all else: "After they had amassed mountains of wealth, they compared the wretchedness of our lives with the calm gentility of theirs and felt that they were truly the favored of God" (Wright, 12 Million 24-25). Searching Paris to understand the reason for this preference, Babu finds a painting of John in which John posed as Jesus, and Babu assumes John is Jesus: "Massa brought Babu to Paris to test Babu! Like that time you test the Jew in Jerusalem" (Wright, Man, God 179). Babu is determined to pass the test: 
"White man kill you and prove you God. Then you rose from dead in three days and you make white man powerful. Now it's black man's turn!" (Wright, Man, God 181). John is "beheaded in a shockingly brutal manner" (Wright, Man, God 181) by Babu as Babu seeks to make "his people strong and powerful like white man" (Wright, Man, God 180). The scene evokes the shaving scene in Melville's text, as Delano witnesses the ritual and could not "resist the vagary, that in the black he saw a headsman, and in the white a man at the block" (Melville 214). Babu succeeds where Babo fails, however, not only drawing blood but decapitating his "master." In this revision, at this moment, John becomes both the blind Delano and the threatened Cereno, but the ultimate representation is the same: the black servant/slave seeks to destroy the oppressive power.

\section{Christian Criticism}

Enhancing this open criticism of religion as despotic power and corrupting force, Wright regularly peppers his work with snippets of Christian hymns that Babu sings. It is one of the things that endears Babu to John and Elise ("He sings and he'll be loads of fun with his rainbow robes and wild religion") ${ }^{46}$ (Wright, Man, God 164). These hymns show how far mission Christianity has infiltrated Babu, becoming part of his everyday, unconscious

\footnotetext{
${ }^{46}$ It is also possible to view Babu's singing of hymns not as a moment of endearment but rather moments of increased primitivism and eroticism. Wright admits in Black Boy that as a young man he found the singing in church evoked an entirely unexpected reaction in him: "It was possible that the sweetly sonorous hymns stimulated me sexually, and it might have been that my fleshy fantasies, in turn, having as their foundation my already inflated sensibility, made me love the masochistic prayers" (113). Such a reading of an erotic/primitive Babu is certainly not unheard of, as Homi Bhabha argues, "In the colonial discourse, that space of the other is always occupied by an idée fixe: despot, heathen, barbarian, chaos, violence" (Bhabha 143). The history of lynching and the fear of black sexuality, as discussed in chapter two, indicates that these terms, "despot, heathen, barbarian, chaos and violence" also carried sexual connotations of dominance, prowess, and stamina. Regardless of the reading - rather one of endearment or one of eroticism - Babu is continually objectified and typed by John and Elise.
} 
experience. Yet, these hymns are perverted by Wright as they foreshadow John's murder and justify his decapitation, at least from Babu's perspective. After being initially struck, Babu sings two excerpts from an 1891 hymn, "I belong to Jesus," by Mawd Fraser: "I belong to Jesus / I am not my own; / All I have and all I am, / Shall be His alone..." and "I belong to Jesus; / He is Lord and King, / Reigning in my inmost heart, / Over ev'rything..." (Wright, Man, God 158). John will come to dominate Babu's life and mind, and he will also come to represent Jesus for Babu, but this opening hymn also shows Babu's growing relationship with Christianity. As John drives on with Babu bleeding in the back, "his singing blends with the jungle tom-toms," melding his faith with his former religion, as he turns to an 1840 hymn, "Sin No More, Thy Soul is Free," by D.W. Whittle: "Sin no more, they soul is free, / Christ has died to ransom thee; / Now the power of sin is o'er. / Jesus bids thee sin no more..." (Wright, Man, God 158-159). Wright increases the heavy-handed symbolism, as Babu has encountered his Christ and will come to believe that his_-and his people's_- "soul is free[d]" by his actions.

The hymns continue throughout the play (as John proclaims, "Goddamn...He's singing again") and they always have significance for the immediate or final action in the radio drama (Wright, Man, God 160). When Babu is taken on as a servant for John and Elise while in Africa, Babu sings an 1871 hymn, "I am Coming to the Cross," by William McDonald, in which he notes that "I am poor and weak, and blind" but "I shall salvation find" (Wright, Man, God 160). As the reader/listener will soon learn, this route to achieving salvation and overcoming his plight includes the murder of Christ - of John - a point quickly foretold in his next hymn, Isaac Watts' “Alas! and Did My Savior Bleed”: “Alas! and did my Savior bleed, / And did my Sovereign die? / Would he devote that sacred head / 
For such a worm as I?" (Wright, Man, God 161). Particularly appropriate given Babu's insistent obsequiousness, this hymn reminds us, once we know the ending, that John, the "Savior," will indeed "bleed" and "die" via the removal of his "sacred head." This particular hymn continues, suggesting that "At the cross," the singer will find "the burden of my [his] heart rolled away" as the resurrection will leave him " happy all the day," a joy and blessing Babu actively seeks through ritual murder (Wright, Man, God 161).

Three additional hymns appear in the play, including the appropriately titled 1904 Philip P. Bliss hymn "The Half was Never Told," and the 1834 Edward Mote piece, "My Hope is Built." The former encourages the hearer to "Repeat the story o'er and o'er," a directive particularly relevant to a revisionist work, particularly one told from the point of view of the "half" whose story was previously "never told" (Wright, Man, God 167). The latter again brings forth images of the ultimate murder, "My hope is built on nothing less / Than Jesus' blood and righteousness" (Wright, Man, God 174). The one hymn that does not immediately reveal a moment of foreshadowing is sung by Babu as he sits on an airplane headed to Paris. This excerpt of "To the Holy Spirit" (author and date unknown), seems overwhelmingly positive: "Oh! clap your hands, mountains / Ye valleys resound! / Oh! leap for joy fountains, / Ye hills, catch the sound" (Wright, Man, God 165-166). Research into the hymn, however, shows that Wright seems to be testing the faith and knowledge of his reader. The lines that follow—not included in the play—are the lines that are the most telling: "All triumph! He liveth, / He lives, as He said; / The Lord hath arisen / Unharm'd from the dead" (Charles 202). Wright is counting on the religious reader to know the lines and see the implicit irony; Babu is counting on the lines—and his new faith—to be true. 
The hymns not only indicate a clear religious presence and serve to foreshadow Babu's mutiny, but they also represent—albeit subtly, Wright's whole-scale denunciation of Christianity. Babu himself claims to be Methodist (Wright, Man, God 172) and the reader deduces that he was part of a Methodist mission church in Africa. The hymns, however, represent multiple traditions, including Baptist, Protestant, and nonconformist denominations. While many churches use an ecumenical approach to hymn inclusionadopting those of multiple traditions - it would have been entirely possible, given their ready availability, for Wright to have focused on hymns descended from the Methodist tradition. Instead, such a mixing of traditions suggests that Wright is attacking not one particular sect or mission, but rather the concept of Christianity, and religion, generally. Indeed, Babu and John each mention the Methodist faith once in the play; throughout the remainder, Babu insists "Babu Christian” (multiple occurrences, including Wright, Man, God 175, 176). Wright sees the church—mission or otherwise — as destructive. Babu is not Wright who, as a boy with his friends, would "hum under our breath": "Amazing grace, how sweet it sounds [...] A bulldog ran my grandma down" (Wright, Black Boy 82-83). Babu has faith, but his faith will not save him, and it certainly will not save John.

Such a condemnation of faith is not surprising, given Wright's own frustrations with his religious upbringing and, more importantly, his belief that religion had stripped Africa of its heritage and its power. When asked by a fellow traveler en route to Africa if he thought "that the African has been improved by accepting Christianity," Wright concluded that "He's certainly more docile" (Wright, Black Power 37). Perhaps more to the point, Wright argued the role of religion in slavery: "Captivity under Christendom blasted our lives, disrupted our families, reached down into the personalities of each one of us and destroyed the very images 
and symbols which had guided our minds and feelings in the effort to live" (Wright, 12

Million 15). Girard sees this role of religion-as-destruction as a normal progression: "Like so many previous religions, ideological, and political enterprises, Christianity suffered persecution while it was weak and became the persecutor as soon as it gained strength" (Girard, The Scapegoat 204). For Wright, Christianity was a way of weakening the African and the slave, both abroad and in America. It chipped away at a person's existent belief system and supplanted it with an emotionally devoid substitute that preached subservience and patience:

However synchronized or not were the motives of the missionaries with those of the imperial financial interests, their actions could not have been more efficient in inflicting lasting psychological damage upon the personalities of the Africans who, though outwardly submissive, were never really deeply converted to a Christianity which rendered them numb to their own dearly bought vision of life, to the values for which they had made untold sacrifices. (Wright, Black Power 191)

Christianity is thus turned on its head in Man, God. Babu, without guile or malevolence, absorbs and re-enacts that which he had been taught. His recreation is no less brutal or, in his own mind, just. Wright takes Melville's Babo, who turns his oppressors' violence and power back upon them, and makes him innocent, seeking not death but rebirth, not end but beginning. It is for Wright the ultimate revision of the Christian myth, come back to haunt its makers. Thus, when critics have argued that the "main comic target of the story is the mutual incomprehension of other cultures' religious practices," they have, quite frankly, missed the point, missed the condescension, and missed the rage (Scofield 189). Mission Christianity is, for Wright, one of many breaches for Wright, a violation of native customs and beliefs that leads to crisis and demands redress and resolution. 


\section{Other Targets}

Religion is not Wright's only target. Wright pushes to the forefront all the issues Melville refuses to deal with in his novella, or deals with without explicit commentary. Where Melville creates a void, or a series of questions, Wright creates a scream, a razing. Religion is missing in any overt form from Melville's text; Wright attacks religion as one of the formative bases for slavery itself. Melville creates a slave able to act obsequiously in order to preserve his mutiny; Wright creates a "servant" whose obsequiousness defies reality. He is childlike and apologetic and infuriating. He is Melville's Babo without the selfpreservation. This characterization too, however, is the fault of the perpetrators. Babu is only who he is made to be:

[...] when Europeans yank a tribal man out of his tribe, shattering his orientation to his world, and inject him suddenly into a new and completely different sphere of living with other assumptions, that tribal man becomes emotionally confused, finds himself acting upon a wide range of conflicting values. His actions become erratic; he tries too quickly to fuse disparate elements into an impossible whole under the condescending monitoring of nervous western tutors whom he seeks to please and, at the same time, struggles to keep peace in his own torn heart. (qtd. in Wright, White Man, Listen! 662)

Babu cannot reconcile these two worlds. He becomes not a dynamic character, but a flat stereotype, a collection of all the multiple worlds thrust upon him. He is a blank slate that mirrors back pieces of what is thrust upon and before him:

And the native, when he looks at the white man looming powerfully above him, feels contradictory emotions struggling in his heart; he both loves and hates him. He loves him because he sees that the white man is powerful, secure, and, in an absentminded and impersonal sort of way, occasionally generous; and he hates him because he knows that the white man's power is being used to strip him slowly of his wealth, of his dignity, of his traditions, and of his life. [....] Charmed by that which he fears, pretending to be Christian to merit white approval, and yet, for the sake of his own pride, partaking of the rituals of his own people in secret, he broods, wonders, and finally loses respect for his own modest handicrafts which now seem childish 
to him in comparison with the mighty and thunderous machinery of the white man. (Wright, Black Power 175)

Thus, Babu stands before John, his "Massa," the man he blesses "with blood" (Wright, Man, God 162) in Africa, and seeks to merge his love and hate of master and self in one action:

"Babu love Massa. Babu want to wash in the blood of the lamb and be whiter than snow" (Wright, Man, God 181). It is a powerful portrayal of the destruction of the African's selfrecognition, and a powerful warning that such a destruction will have equally — if not morepowerful ramifications for the white man.

This destruction is simultaneously yet another breach/crisis that demands redress and resolution, and a continuation of the unending breach/crisis. Babu, as the non-white African, demonstrates the crisis inherent to modern Western involvement in Africa, but his plight is also a reminder of the continuing crisis set forth by earlier involvement in Africa, and by white privilege in multiple guises. Wright reminds audiences that this is a new(er) manifestation of an old problem, one clearly visible in Melville and in Delano, and one still without resolution. The act of revision is not, for Melville, Wright, Lowell or others, simply the act of re-telling. It is an act meant to remind the audience of the crisis at hand, and if done properly, it is an act meant to rekindle the crisis itself as a way of demanding resolution. In his discussion of Turner, Victor Raybin frames this move in a way helpful and relevant to this study:

When, to return to Turner's frame, crisis has so developed that established structures are overturned and the group has moved to a liminal mode, when traditional juridical or ritualistic strategies prove unsatisfactory as modes of redressive action, the group will seek to extricate itself from its dilemma by turning to symbolic action, by adapting models, constructed in the antistructural artistic frame. (Raybin 27) 
Art, for Wright, becomes the antistructural, a way to criticize the artistic (Melville) and the jural/social in many forms.

Thus, while Delano's blindness in Melville's text becomes John and Elise's condescension in Wright's play, as previously mentioned, Wright takes it several steps further in order to heighten his criticisms. John moves from a blind Delano whose prejudices and social stratification blind him, to a doomed Cereno. Cereno must "follow his leader" to death in Melville's text - a change from the original historical text where Babo and Mure are killed and Cereno survives. Wright inverts both narratives, killing John and allowing Babu to survive. His original Delano-like qualities are replaced by the Parisian police who release Babu, despite his confession, because they cannot believe an African man capable of such a feat: "He had no motive whatsoever for committing the crime and he tried ever so clumsily to invent one, but was too naïve to know how" (Wright, Man, God 182). Indeed, when the crime goes unsolved, the police go so far as to blame the confessed killer, Babu: "What fouled up this investigation were the wild ideas of that crazy African" (Wright, Man, God 184). Whereas all comes to light in Melville, the blindness continues in Wright's work, suggesting that the destruction and violence is far from over. There is no redress and resolution possible in Wright's text; he strives, repeatedly, to push us back into crisis. He wants us to take sides, but he refuses to allow us to do so blindly.

Wright revises Melville, indeed berates Melville, in order to condemn it all: white, black, Africa, America, Europe, religion, and humanity. He continually calls forth Melville — via Babu's name, his obsequious nature, John and Elise's blindness, the unwillingness of the police to see that which is right before them, and the servant/slave uprooted from Africa - in order to create the liminal. The space he creates, the threshold 
between Melville's potentially anti-slavery text and Wright's anti-religion/slavery/ colonialism text, demonstrates how far society had not come in the near century between texts. Certainly one should be able to read the anger and disgust present in Man, God (although many critics have failed to do so, instead calling it comic or ironic) ${ }^{47}$ without seeing the connections to Melville, but seeing the connections reinforces Wright's reasons for anger and condemnation. Nearly 100 years later, Wright is still waiting—or perhaps better stated, done waiting - for the answers to Melville's questions and for the untying of Melville’s “Gordian knot.”

Instead, Wright is not just demonstrating society's failures, he is warning us of impending disaster. For Wright, Africa, while complicated and foreign to him, is nonetheless a final litmus test: "The Western world has one last opportunity in Africa to determine if its ideals can be generously shared, if it dares to act upon its deepest convictions" (Wright, Black Power 11). It is the American black who "consistently and passionately raises the question of freedom," (Wright, White Man, Listen! 669) but American blacks cannot be, for Wright, the last stand for freedom and, ironically, American idealism: "They are passionately loyal because they are not psychologically free enough to be traitors" (Wright, White Man, Listen! 669). Instead, they are "trapped in and by their loyalties. But that loyalty has kept them in a negative position" (Wright, White Man, Listen! 669). Instead, it is within Africa that the white man can find redemption and the black African can see what American blacks and whites cannot: "They [the African revolutionaries] lived in two worlds. But they didn't really and deeply believe in either of those worlds. The world that they really wanted, the

\footnotetext{
${ }^{47}$ Such readings of Wright seem intentionally obtuse, as if reading the work as comic or ironic or suggestive will somehow supplant the anger aimed at Western and African society as a whole. To displace the anger is to free oneself from Wright's condemnation. It seems a failed endeavor, however.
} 
world that would be the home of their hearts, had not yet come into being" (Wright, White

Man, Listen! 794). If there is room for redress, if there is an opportunity to change and to do better, that opportunity, for Wright, is in Africa.

And thus Wright returns his readers to Turner's concept of the social drama. For his work is the social drama, the liminal, the subjunctive. It suggests that what remains is insufficient and that what is better-what is equal, true, and right—is possible. As Raybin argues:

Crisis exposes for discussion and evaluation doxa, the underlying, normally unquestioned, and even unrecognized principles on which the social superstructure is based. When such principles become discussable, they simultaneously become open to change, to ideological examination and assault. Form solid foundation we move to fluid 'anti-structure,' and in what Turner calls a 'liminal' phase of unfettered possibilities, a rebellious, revolutionary, racially new set of suddenly plausible ordering principles 'takes up its menacing stance in the forum itself and, as it were, dares the representative to grapple with it' [...]. Under such circumstances, I argue, art is looked to, indeed is expected, to offer the signs, innovated meanings, and orderings that will permit a return to stability. (Raybin 25)

Given Wright's struggle against religion, colonialism and white privilege, it perhaps goes without saying that Wright is decidedly, in this work, "anti-structure." It is within the dramatic revision Wright generates, and the subsequent liminal space that revision creates, that Wright is able to offer both the possibility of difference and insist on the necessity of change.

In the Spring semester of 2011, Dr. Megan Goodwin, then a Teaching Fellow for the University of North Carolina at Chapel Hill's (UNC-CH) Department of Religious Studies, assigned Man, God as part of her course, Religion 424: Theories of Sex/Gender, Sexuality, and Religion. She agreed to distribute a short questionnaire on my behalf, in which I asked 
24 students, all undergraduates at UNC-CH, to discuss six basic questions ${ }^{48}$ in order to determine the effectiveness of this play for an outside audience who were all unaware of the connections to Benito Cereno (and many of whom were unlikely to have ever read Benito Cereno). None of the students had heard of Wright's play previously. Indeed, only six had heard of Wright himself previously and of those six, four had read or heard of Native Son while two had read or heard of Black Boy. One student noted that s/he had heard of Wright because "Multiple individuals at my home church challenged the presence of Richard Wright's Native Son on the local high school's summer reading list because the writing was too 'sexually explicit and graphic' and 'racist against white people"' (Joyce qtd. in Malburne-Wade, 2011).

Perhaps unsurprisingly — given the violence present in the text, the questioning of Western civilization and religion, and the flippant tone of Wright's piece—students struggled with their views of the material. Babu's actions split the class as one student found that John and Babu were both victims, two students found the murder understandable, seven found the murder justifiable, one found the murder not excused, nine found the murder not justified, and seven found the murder undeserved. Nine students held Babu responsible for his actions; five found that he could not be held responsible given the circumstances. One student vehemently believed John deserved his fate: "My initial reaction when Babu killed

\footnotetext{
${ }^{48}$ Students were asked to address the following: 1) What would you say is Wright's main point in Man, God Ain't Like That...? What is he trying to argue? 2) Is Babu responsible for the murder of John, or is he somehow justified or excused for the killing? Does John deserve his fate? 3) Would you call this a political text? A religious text? Both? Why? 4) This text was originally a German radio play and was therefore meant to be heard, not read. What sounds do you imagine would be played along with the reading? What sounds would help this play have meaning and impact for the listener? Would hearing this play change its impact for you? 5) Had you ever heard of this play or Richard Wright before this class? What did you know about either/both (if anything)? 6) Did you like it? Why/why not?
} 
John was 'serves you right, you jackass!"”49 (Brackett qtd. in Malburne-Wade, 2011). Other students were more nuanced or conflicted in their readings. One student concluded, "The theme that the 'white colonizer' reaps what he has sown through his own will to power and cultivated ignorance of people who are other than himself is portrayed violently and is thought provoking" (Mattheis qtd. in Malburne-Wade, 2011). Another student noted that "both the white and black man (men) are flawed" and "Because of religion then, neither group can be seen as completely blameless in the narrative: they each have their parts to play in causing the chain of events which culminate in John's murder" (Khor qtd. in MalburneWade, 2011). The fact that students are grappling with such difficulty after reading of a brutal decapitation suggests that Wright has approached, if not achieved, his goal of challenging traditional views of power and supremacy. Of course, it must be noted that a modern audience will obviously be more attuned to the problems of colonization, but the impact on these students remains relevant and worth noting.

Additionally, most students seemed quite adept at reading the intentions of the radio play, although many had noted that hearing the play rather than reading it would have greatly increased its impact. Students repeatedly mentioned the importance of hearing the hymns in order to connect further with Babu. One student went so far as to note that "Hearing the play would allow me to receive a more religious message and less political" (Canty qtd. in Malburne-Wade, 2011). Nonetheless, most students (23) found that Wright's text was

\footnotetext{
${ }^{49}$ This presentation, including the single strikethrough, is found in the student's original response, indicating a desire to fully express his/her initial opinion and his/her awareness of accepted academic writing conventions.
} 
intended to be both a political and a religious text. ${ }^{50}$ Students noted, "Christianity did not simply represent a set of religious beliefs, but the white Western world and its ideology" (Joyce qtd. in Malburne-Wade, 2011) and insisted the play demonstrated "the hypocrisy within religion itself" as John and Elise accept Babu's Christianity and "juju" when it is convenient for their purposes (Khor qtd. in Malburne-Wade, 2011). Yet they also noted the political impact of this play as "it deals with the tensions between different groups of people" (Caudill qtd. in Malburne-Wade, 2011) and it "speaks to the formation and sustaining of Anglo-centric hegemony" (Cox qtd. in Malburne-Wade, 2011). One student perhaps summed up the anti-colonialist impulse of the play best when she stated, rather simply: "I'm not completely sure what Wright is thinking, but it seems like he might be wanting Americans to leave Africans alone" (Mooneyham qtd. in Malburne-Wade, 2011). Overall, Wright's ability to generate these questions for students indicates that he has invoked the subjunctive and opened the door to alternative understandings of religion, race, colonialism, and culture. That Wright is able to generate these liminal moments for these students without their knowledge of his revision and without their knowledge of Benito Cereno suggests both that the text is fully functional without such knowledge, but also suggests that the possibility for increased depth of understanding remains.

\section{Defining the Past, Understanding the Present III: Herman Melville and Robert Lowell} Play Summary, Production History, and Critical Reception

Robert Lowell's revision of Melville's Benito Cereno shares the same title, and it certainly received more recognition than Wright's text. As noted at the start of this chapter,

\footnotetext{
${ }^{50}$ One student found it to be solely a political text. Of the 23 who found the text to be both political and religious, three students indicated it was both but more political than religious; two students indicated that it was both but more religious than political.
} 
Lowell's 1964 play was part of a trilogy that won five Obie Awards, including Best Play. The play was "enjoying capacity business" at the time of its closing ("“The Old Glory" 14). The play originally ran the "maximum time allotted," six-weeks, as part of a limited engagement; it later re-opened at a second theater and continued its run (“"The Old Glory”" 14). In the published manuscript, Lowell provides an acknowledgment page where he recognizes Melville's Benito Cereno as part of his source material; he also lists a collection of Hawthorne's work and recognizes the stories as the source material for the other two plays in the trilogy (which do not fall under the purview of this chapter).

Criticism of the play has been varied and inconsistent. One reviewer of a later (1975) Chicago production of the play noted that Lowell was guilty of "further complicating" his characters' "lives with conflicting emotions and human ambivalence" (Winter B2). Some find that he has remained surprisingly true to Melville's novella ("Lowell has actually diverged very little from the original") (Yankowtiz 83) while others have seen him as vacillating between "radical and conservative methods" in his revision (Schotter 63). Critics are equally split regarding the effectiveness of the changes Lowell makes, and the general clarity and efficacy of his message.

Lowell does remain, as Melville did with Delano's original narrative, generally consistent with the overall premise and design of his predecessor's (Melville's) text. Critics such as David Knauf, ${ }^{51}$ Gary B. Herbert, ${ }^{52}$ George Ralph,${ }^{53}$ Jesse Schotter, ${ }^{54}$ and Susan

\footnotetext{
${ }^{51}$ See "Notes on Mystery, Suspense, and Complicity: Lowell's Theatricalization of Melville's 'Benito Cereno."”

${ }^{52}$ See "Master and Slave in Robert Lowell's 'Benito Cereno.'

${ }^{53}$ See "History and Prophecy in 'Benito Cereno.'
} 
Yankowitz $^{55}$ have done an admirable job extensively outlining that which has remained consistent between the texts and that which Lowell has altered. However, I contend that Lowell used more than just the source material he acknowledged, calling instead upon not only Melville's novella, but also Delano's original narrative and Wright's revision.

Lowell uses familiar characters in his play, including Captains Delano and Cereno, the slaves Babu and Atufal, and assorted Spaniards and slaves aboard the ship. The San Dominick remains, as it does in Melville's text, wrapped in mystery and confusion. As in Melville, Delano boards the Spanish ship to ascertain what is troubling the wayward vessel, and attempts to help the captain and his ship, remarkably blind to the facts at hand. As in Melville, Babu has led a mutiny and the members of the ship work to conceal their true intentions. The bones of the slave-owner, Aranda, are eventually revealed as the new masthead, as they are in Melville's novella.

\section{Lowell's Changes}

There are several important changes made by Lowell, however. As Yankowitz noted, Lowell writes his play as a "poetic drama," using rhyme and meter throughout, consistent with his own training as a poet, which "allows for compression and economy, qualities more necessary to drama than to fiction" (84). Indeed, as one part of a trilogy, this play unfolds much more quickly than Melville's novella does. In order to bring Delano's inner thoughts to the forefront of the play, Lowell adds a character, John Perkins, who serves as Delano's boatswain and with whom Delano can hold important conversations that would otherwise be difficult to dramatize. What critics have failed to note is that such a change is consistent with

54 See "Adaptation Liberal and Conservative: Benito Cereno and Robert Lowell's Literary and Racial Politics."

${ }^{55}$ See "Lowell's Benito Cereno: An Investigation of American Innocence." 
Delano's original narrative, which begins with the narrative of an unnamed sailor ("the officer who had the care of the log book") and is interrupted by the writings and deposition of the midshipman, Luther (Delano 318). As in Delano's narrative, the secondary voice from Delano's ship serves as a means of adding detail and offering an opinion against which one can judge Delano's speech and attitude.

Lowell (almost) maintains one ship name from Melville's text, the San Dominick becomes the San Domingo, but Lowell, like Melville, completely alters the name of Delano's ship. Thus the ship that began as the Perseverance in Delano's narrative becomes the Bachelor's Delight ${ }^{56}$ in Melville and the President Adams in Lowell. Such a change, as Schotter notes, allowed Lowell "to spark a conversation about the victory of Jefferson over Adams" in 1800, the year of the play's action (68). Perkins bemoans the loss, noting that he distrusts Jefferson's "being so close to the French" and prefers Adams, the "dry fellow" to Jefferson (Lowell 121). Against this canvas, Delano can begin to show himself as the selfcentered man he remains in all versions of the text. He blames Adams for having "rather let us down / by losing the election just after we had named this ship" and notes that such a "nervous" and "dry fellow" does not appeal to the masses: "When you've travelled as much as I have, / you'll learn that that sort doesn't export" (Lowell 121). He berates Perkins for mentioning that Jefferson "has two illegitimate Negro children," (Lowell 122) noting "That's the quickest way / to raise the blacks to our level" (Lowell 122) and arguing that "In a civilized country, Perkins, / everyone disbelieves in slavery, / everyone disbelieves in slavery and wants slaves" (Lowell 124). Against the backdrop of Perkins' "Puritan" attitude, "all

\footnotetext{
${ }^{56}$ Perkins nonetheless references Melville's boat, noting that he wishes he were "at home with my wife; these world cruises are only for bachelors" (Lowell 120). Perkins, as it were, does not "delight" in the extended time away or the life aboard the ship.
} 
faith and fire," Lowell's Delano is able to quickly articulate the murky and at times contradictory views on slavery espoused by the original Delano, Melville's Delano, and Wright's John (Lowell 125).

Like the original Delano and Melville's Delano, Lowell's American captain has strong views on other cultures as well, noting:

A Spaniard isn't a negro under the skin, particularly a Spaniard from Spainthese South American ones mix too much with the Indians. Once you get inside a Spaniard, he talks about as well as your wife in Duxbury. ${ }^{57}$ (Lowell 126-127)

Of course not being a "negro under the skin" certainly does not place the Spanish Cereno on equal footing. Playing on Delano's stated distrust of "South American ones," Lowell's Cereno "looks more like a Mexican planter than a seaman" and enters the stage "wearing a sombrero" (Lowell 129, 130). Delano quickly reverts to blaming Cereno for the disorder aboard the ship, just as the original Delano and Melville's Delano do, noting the boat lacks "severe superior officers," and that "if this Benito were a man of energy... / a Yankee..." the boat would be functioning appropriately (Lowell 134, 135). Indeed, it seems that for Delano, it is Cereno's "little yellow hands" that "got their command before they held a rope" are to blame for the troubles aboard the San Domingo (Lowell 142).

Delano and Wright: Unacknowledged Inspirations

Part of Delano's distrust of Cereno revolves around his failure to speak openly about money. Melville omitted the financial negotiations and complaints that dominate Delano's original narrative. Lowell's inclusion of such details signal that he clearly also relied on the

\footnotetext{
${ }^{57}$ This section is an extension of Melville's original wherein the reader is privy to Delano's thoughts: "Spaniards in the main are as good folks as any in Duxbury, Massachusetts" (206).
} 
original text and not simply upon Melville's revision. In the original, Delano refers to a moment when he "requested the captain to send" his slave on deck "as the business about which we were to talk could not be conveniently communicated in presence of a third person" (Delano 324). Cereno, of course, refuses, as he cannot dismiss his slave ${ }^{58}$. In Lowell's play, Delano also attempts to dismiss Babu in order to talk "about your expenses," and he outlines the costs associated with this rescue, including "the sails, ropes, food and carpentry" that he is willing to offer Cereno "at cost" (Lowell 182). In the original, Cereno attempts to avoid paying Delano, who must go to court to recoup a partial payment of "eight thousand dollars [...] for services rendered" (Delano 330). Lowell's Cereno hints at a similar form of resistance when he rebukes Delano's calculations: "I know, you are a merchant / I suppose I ought to pay you for our lives" (Lowell 182). Such a response dents the altruistic façade Delano puts forth in Lowell's text. Schotter agrees: "For both Perkins and Delano, all seeming philanthropy and charity is actually only commerce, and is rooted in the enforcement, violent if necessary, of property rights" ${ }^{\text {"59 }}$ (69).

Babu and the slaves are, however, ultimately the characters who bring forth Delano's true character; Babu also serves as the biggest link between Lowell's play and Wright's radio play. The change of the name from "Babo" to "Babu" strongly suggests that Lowell is acknowledging Wright's text, although indirectly (just as Wright used the name to show the link to Melville). Yankowitz suggests that this change is "seemingly based on the mere

\footnotetext{
${ }^{58}$ In the original narrative, Mure, not Babo, is the slave who constantly escorts Cereno. Mure is removed in Melville and Babo comes to represent both of the original leaders, most likely for the sake of clarity. Lowell keeps the singular leader character and calls him Babu. ${ }^{59}$ Critic David Knauf disagrees with this reading, noting that Lowell's Delano takes after Melville's Delano, "from first to last a kind, honest, well-meaning man" who is "more the victim" of his good-naturedness "than of any deficiency of character" (41). Both Lowell and Melville, however, work to portray Delano as complicated, but certainly not blameless.
} 
rhythmic sound" of Babu and "its African-like connotations" (84) and Knauf suggests that

"Lowell perhaps made the vowel change to avoid an unfortunate association with cleanser,"60 but the connections to Wright's text appear stronger. Babu presents himself like Wright's Babu—overly obsequious: "Don't speak of Babu. Babu is the dirt under your feet" (Lowell 140). But, unlike Wright's Babu who lacked guile and only attempted to seize power when he thought himself seeking the Divine, Lowell's Babu is playing a part, much like Melville's Babo.

Lowell uses Babu to recall Wright in one other way. In Melville's text, Delano addresses Cereno regarding Babo, stating, rather ironically, "I envy you such a friend; slave I cannot call him" (176). In Lowell's text, Delano's line is slightly altered: "You are a good fellow, Babu. / You are the salt of the earth. I envy you, Don Benito; / he is not slave, Sir, but your friend" (140). "Salt of the earth" is a biblical term, originating in Matthew 5:13, originally intending to demonstrate something of great worth. In Lowell's text, however, Cereno quickly turns it around, using it as a moment of foreshadowing: "Yes, he is salt in my wounds. / I can never repay him, I mean" (141). Using a biblical reference as a form of foreshadowing evokes Wright's consistent use of hymns as a way of indicating the bloodshed still to come.

Faced with Babu and the slaves upon deck, Lowell's Delano cannot hide his discomfort and it is again a small textual change that is pivotal in revealing Lowell's intentions for his character. In Melville, Delano has a moment of doubt about the San Dominick where he starts to see (and then dismisses) the truth. Schotter is quick to point out

\footnotetext{
${ }^{60}$ There was a brand of cleanser known as Bab-O, similar to Comet, that was manufactured beginning in the mid-nineteenth century.
} 
the similarities between Delano's inner dialogue in Melville and his comments to Perkins in Lowell, but Schotter fails to comment on the pivotal line. In Melville, Delano muses:

'What, I, Amasa Delano-Jack of the Beach, as they called me when a lad-I, Amasa; the same that, duck-satchel in hand, used to paddle along the waterside to the school-house made from the old hulk-I, little Jack of the Beach, that used to go berrying with cousin Nat and the rest; I to be murdered here at the ends of the earth, on board a haunted pirate-ship by a horrible Spaniard? Too nonsensical to think of! Who would murder Amasa Delano? His conscience is clean. There is someone above. Fie, fie, Jack of the Beach! you are a child indeed; a child of the second childhood, old boy; you are beginning to dote and drule, I'm afraid.' (203-204)

Lowell offers many of the same details, omitting and embellishing some as he references his "Jack-of-the-beach" nickname, the "Duxbury shore," his "duck-satchel” and "gathering huckleberries along the marsh with / Cousin Nat" (Lowell 160-161). The conclusion of his speech, however, is pivotal:

How can I be killed now at the ends of the earth by this insane Spaniard?

Who could want to murder Amasa Delano?

My conscience is clean. God is good.

What am I doing on board this nigger-pirate ship? (161)

Melville's Delano briefly fears the Spaniard, but Lowell's Delano reveals his true fears, a deeper, more complicated racism, a fear of all others, and a distrust of, in Perkins' words, "Brown men in charge of black men" (Lowell 134). Lowell's decision to be so blatant with Delano’s (and Perkins') racism takes a morally ambiguous Delano from Melville and exposes him for his true beliefs. In doing so, Lowell moves his Delano-despite the linguistic similarities - away from Melville's version and closer to the Delano-like character provided by Wright. 


\section{Babu the Breach}

Babu himself seems to understand Delano's true character, and he pushes Delano to his breaking point. When Delano compliments Babu's caretaking skills, Babu notes, "You say such beautiful things / the United States must be a paradise for people like Babu" (Lowell 147). Cereno is forced to backtrack, stating, "I don't know. / We have our faults" (Lowell 147). Delano struggles with his own portrayal of American life and justice, noting, "I wish people wouldn't take me as a representative of our country: / America's one thing, I am another; / we shouldn't have to bear one another's burdens," but, of course, Delano does represent America for those aboard the ship, and for the audience (Lowell 149). And that America is one that is troubled by its own conflicting beliefs. Babu again goads Delano, stating, "They say all men are created equal in North America," to which Delano snaps, "We prefer merit to birth, boy" (Lowell 173). Schotter notes, "his infantilizing word 'boy' betrays the fact that, for slaves, at the very least, there is not such difference between the Old and the New Worlds" (66). When Babu again pushes Delano, suggesting that "Jefferson, the King of your Republic, / would like to free his slaves," Delano counters, "Jefferson has read too many books, boy, / but you can trust him. He's a gentleman and an American! / He's not lifting a finger to free his slaves" (Lowell 175). For Delano, then, a gentleman and an America is a slave-holder. Just a few lines later, Delano refers to Babu as "boy" for a third time, clearly reinforcing his views - and his representation of America's views — on slaves.

Perhaps one of the biggest changes Lowell makes is to alter the ending in a way that sets it apart from the texts of Delano, Melville, and Wright, at least in form (if not in meaning). Delano and Babu's verbal sparring leads to the climax where Babu, unable to conceal his hatred for Delano's condescension, reveals his role as conspirator: "I can't stand 
any more of their insolence; / the Americans treat us like their slaves!" (Lowell 185). Even when the skeleton of Don Aranda is revealed upon the deck, however, Delano cannot see the truth, instead threatening Cereno who cries out, "Don't you understand? I am as powerless as you are!" (Lowell 186). Still, however, the Americans remain blind, thinking it Atufal and not Babu who is the ringleader. When reinforcements arrive and shoot down many of the slaves, Perkins states "We have killed King Atufal, / we have killed their ringleader" (Lowell 193). Enraged, Babu cannot remain silent: "I was the King. Babu, not Atufal / was the king, who planned, dared and carried out / the seizure of this ship..." (Lowell 193).

In one of the most difficult scenes to fully grasp, Babu offers the speech that brings the close to the play. While picking up a crown, a cane and a ball, he states:

\section{This is my crown.}

This is my rod.

This is the earth.

This is the arm of the angry God. (Lowell 193)

Upon smashing the ball with his cane, Perkins asks Delano to spare Babu while Cereno notes, "My God how little these people understand" (Lowell 194). Babu waves a white handkerchief, stating: "Yankee Master understand me. This future is with us" (Lowell 194). Delano tells him "This is your future" while unloading all six bullets of his pistol into Babu (Lowell 194).

"Moral Myopia"61

While critics have consistently agreed that Lowell meant to refocus Melville's piece and his concern with slavery onto America's ongoing struggle with race relations and/or colonialism, they have struggled with what exactly Lowell is saying about said relations. Knauf has argued that Delano remains blind at the end of Lowell's text, that he "does not

${ }^{61}$ This phrase appears in a quote from David Knauf, next page. 
solve the mystery of the San Domingo: the dark labyrinth of man's inhumanity to man" (45). Knauf reads the ending as commenting on the continuing struggle for understanding in American race relations, a way of highlighting an "America inflicted with moral myopia and dedicated, since its foundation, to bloodshed and violence in the protection of a privileged class" (Knauf 45). Schotter and Yankowitz read the ending in a similar fashion, but expand this reading to include America's international presence and role. Schotter notes that "Like Melville's novella, Lowell's play thus ends in a stalemate and violence; the whites have defeated the blacks in this battle, but a wider war between the races looms on the horizon, in Melville in the form of the impending Civil War, in Lowell as the Civil Rights Movement and decolonization struggles" (70). Yankowitz sees Lowell as demonstrating that Americans are "Unable to tolerate difference of color or morality" and are "convinced of their rightness (and therefore, their responsibility to the rest of the world)" and that this righteousness causes them to participate in "suppressing and repressing any attempt made by a people to find its own voice and own morality" (88). George Ralph expresses a more fatalistic understanding: "When Babu smashes the ball which he says is the earth, and Delano answers him with the revolver, the future relationship between the two races is clearly drawn" (160). It is clear that all agree Lowell is making a statement about America or race or colonialism, but it is unclear what exactly such a statement may be.

Schotter further suggests that this miasma is inherent to and a result of Lowell's own personal struggles with race and change. Schotter asserts, "While the public Lowell welcomes those fighting against inequality, $[\ldots]$ the private Lowell is far more pessimistic about the prospect of political change, naturally fearful of the violence and ethical dilemmas inherent in revolution" (63). While it seems difficult to grapple with the fact that "Lowell at 
times expresses a sense of ambivalence about decolonization struggles and flirts with an identification with his more imperial, white characters," Schotter supports this allegation with Lowell's own writing. In a letter to a fellow poet, Lowell clearly indicated that he was struggling with his own portrayals as well as Melville's original text:

[...] how can we handle the whole plot so as not to make it rather shockingly anti-Negro? What I'd hope for would be something neutral, rather what's happening now, wrong blazing into a holocaust, no one innocent. But the action - in Melville the Negroes with their bloodthirsty servility are symbolic demons - on the stage will be much more unbearable than read, or even worse, likely to seem a sadistic, unfelt farce. (Lowell qtd. in Schotter 74)

Lowell mirrors Melville where all are questioned and all are questionable. Such a reading is contrary to the anti-racism/anti-colonialism stance many wish to attribute to Lowell, but it begins to make the ending clearer as there are no victors in such a "holocaust."

Gary B. Herbert is successful in merging these disparate readings in a way that makes the text more palatable and more impactful on many levels, while also lending clarity to the ending. Using a Hegelian lens, Herbert reads Delano and Babu as locked in a master/slave dialectic. Babu, who indeed has an increased presence in Lowell's text, refused to be a "complete slave" as he is not "in bondage [...] in consciousness" (295). Indeed, when Babu's push for freedom and return to Senegal is clearly thwarted, he pushes for recognition and the ability to be seen, heard, and recognized as the leader of the mutiny. Herbert sees the ensuing final stand-off between Delano and Babu as the confrontation between "two entirely free men, two masters who must face each other" (300). He asserts that Delano recognizes Babu as a "master who has lost, not a slave" and knows that ultimately, despite the white flag, Babu will never surrender (300). Babu's claim that "The future is with us" is read by Herbert as referring to the future of the world resting with masters, with true men, and not 
with slavery (Lowell 194). Such a reading frees both Delano and Babu and it is thus a tempting reading, one that makes both men if not noble, at least empowered.

Herbert's reading of Babu, with his need to be recognized, seems accurate. He certainly does not accept his role as slave (in any of the four texts discussed in this study). Reading Delano as respecting Babu as an equal seems deeply flawed, however, given Lowell's own writings on the matter and on the play itself. Delano repeatedly referring to Babu as "boy" undermines this assertion of master-recognizing-master. Delano's need to shoot Babu six times also indicates a sense of rage and frustration that would not be found in an empowered slaying of a worthy adversary.

What these complex and varied readings suggest, however, is that Lowell was drawn to the play — and reproduced the original texts — because of the murkiness it presents and represents. Indeed, Melville, Wright and Lowell all use their plays to dwell in this murkiness, and to suggest means of redress that indicate the crisis is not yet over. We cannot yet find redress and resolution because we have not yet fully accepted our own roles — and sides - in the crisis. In discussing Lowell's play, Yankowitz notes that Delano's murder of Babu is "perpetuating the cycle of violence" all the while leaving Delano blissfully "unaware of his share of guilt" (90). Thus, "Even at the conclusion of the play, he sees himself as the righteous avenger; he learns no lesson and remains blind to his true relationship to the racial situation which has created the crisis" (90). This is perhaps the most important lesson the reader/viewer can take away from all four texts. Until each and every person comes to terms with the crisis itself — and his or her own role within that crisis—redress and resolution will remain ever elusive. Delano illustrates his own refusal of self-awareness in his narrative and 
Melville, Wright, and Lowell demonstrate an ongoing trend in American history and politics where such self-awareness is still missing a century later.

Many would argue that such an awareness is still needed in the United States, particularly given that Lowell's revision was itself again revised and produced in 1997, this time told from "the slaves' perspective," returning in many ways to Wright's revision and including "such African elements as dance, music, imagery and text" (Palmer). Such revisions demonstrate that despite the efforts of Melville, Wright, and Lowell, there is much work still to be done in order to find resolution. Richard Schechner would suggest that these dramas and texts continue to proliferate because we acknowledge, at least subconsciously, that we are not able to move on: "Theater and ordinary life are a möbius strip, each turning into the other" (Schechner 14). Thus, while the slave trade may have ended, its impact weighs heavily on U.S. consciousness and our cultural imagination. Similarly, Wright would likely indicate that the West has failed to make amends—or allow for selfdetermination - in Africa, and so, as events in countries such as Egypt and South Africa continue to show, the crisis continues. Given that we appear well beyond the moment where redress in its typical forms, including legal and state-sponsored changes, will be enough, art remains as one way to remind us of how far we have come, and of how very far we have left to go. 
CHAPTER 4: CELEBRATION OF FAMILY AS A MEANS OF DIFFERENCE AND HOPE: HANSBERRY'S A RAISIN IN THE SUN AND ODETS' AWAKE AND SING!

In 1959, theater director and drama critic Harold Clurman noted a trend in literature, history, and drama that has continued to the present day: "There is a tendency nowadays to downgrade the thirties" (Clurman, "The Theatre" 3). At best, the decade's concerns with communism, radicalism, and the effects of the Depression seem oddly dated. At worst, such forays remain dangerous — "tainted with some degree of "pink"”-reminding scholars of a time when intellectuals paid the price for forays into radical philosophy (Clurman, "The Theatre" 3). This project's discussion of McCarthyism and the fear of radicals sets the stage for understanding such a bias.

Nonetheless, in the same year that Clurman declared a lagging interest in the 1930s, Lorraine Hansberry's A Raisin in the Sun took the stage. The play itself shows a remarkable interest in the thirties, specifically in Clifford Odets' 1935 production, Awake and Sing! There is a direct and powerful relationship between the two family dramas that has yet to be fully discussed or fully understood. While both plays are overtly concerned with the impacts of economics and family, Odets' play focuses on negative associations of family, envisioning it as a disseminating vehicle for what he views as destructive, capitalist thinking. For Odets, it was this thinking, this focus on money above all else, that infiltrated all levels of American society and placed our "humanity [...] in constant danger of being destroyed" (Clurman, Introduction xiii). Such a focus has often left critics, commentators, and audiences frustrated and confused as they struggle to empathize with any of the characters. Because of this 
struggle, Odets loses some of his ability to engage the audience with his larger societal criticisms; indeed, while Odets is not alone in his belief that the family is the cornerstone of ideological development, most audiences were not (and likely are still not) prepared to accept whole-scale criticism of the American family, one of the most personal — and intimateconnections we have. Hansberry, alternatively, celebrates the family as a means of counteracting economic, racial, and political pressures. By revising Odets' work and taking much of the negative focus off the family itself, Hansberry is able to generate not only the more successful drama (in terms of its resonance with audiences, its financial success, and its artistic recognition), but also the more critical drama, one that is able to question and critique the forces that continually oppress the characters.

\section{Defining the Social Dramas of the Literary and Historical Precedents}

Play Summary and Production History: Awake and Sing!

Odets' play tells the story of three generations of a lower-middle class Jewish family, the Bergers, living in the same small Bronx apartment home during 1935. The Berger family struggles to maintain middle-class dignity during the Great Depression. Bessie Berger, the matriarch, dominates her family. Focused on materialism and maintaining appearances, she pushes the men in her life — her husband, Myron, and her son, Ralph— to earn more money; she pushes her pregnant daughter, Hennie, into a loveless marriage, all in the name of status. Bessie's brother, Uncle Morty, who does not live in the apartment, is the staunch Capitalist of the family, a business owner and the most financially successful person in the family. Bessie and Morty's father, Jacob, lives with Bessie and her family but eventually dies (or commits suicide, depending on your reading of his "accident"), leaving his insurance money to his grandson Ralph, in the hopes that Ralph will break away from the succubus that is his 
capitalist family and will, eventually, seek the path of purifying Marxism. Ralph closes the play with two idealistic speeches in which he relinquishes the money to his demanding mother, feels reborn, and embraces the path left to him by his grandfather as he sets out to join the Left and "fix it so life won't be printed on dollar bills" (Odets 97).

The play itself, the first of Odets' full-length plays to be produced, was originally titled I Got the Blues, but was renamed before the play began production (Clurman, The Fervent Years 143-144). In 1935, Harold Clurman directed the play, which ran for 184 performances at the Belasco Theatre in New York before closing and reopening at the same theatre for another 24 performances later that year ("Awake and Sing!"). Financially, "Awake and Sing never made much money" (Clurman, The Fervent Years 153) for much the same reason that many of these plays did not fare well at the box office: "the play attracted an important but small part of the theatre-going public: those who bought the cheaper seats" (Clurman, The Fervent Years 153). Over the years, the play has been revived repeatedly on Broadway in 1938, 1939, 1970, 1979, 1984, 1993, 1995, and 2006, but never with near the same success as the original run (“Awake and Sing!”). The play has also seen a number of off-Broadway productions, as well as limited international stagings. In 1972, Walter Matthau starred in a televised version of the play (now available on DVD).

According to Clurman, the play received a "very favorable but not sensational newspaper reception" (The Fervent Years 149). Put more precisely, critics have been split on Odets' work generally through the years, and Awake and Sing! is no exception. Indeed, many critics have conflicting views on Odets' work, sometimes within a single review. In a 1935 New York Times review, Brooks Atkinson calls Odets a "new dramatist of exciting potentialities" who "has a rare sense of the loneliness of the individual" (X1). Atkinson also 
notes that the play is, however, "not completely fulfilled or thoroughly expressed" and the ending has "a rapture that sounds almost like a sense of relief" but that leaves viewers "bewildered about the motive and logic of the play" (X1). Discussing the 2006 revival of the play, Misha Berson notes that the ending of play remains problematic for contemporary audiences (and readers):

In a post-Communist era of political disengagement and skepticism, Ralph's idealistic zeal tends to come off as a stale leftist rallying cry from (literally) out of left field. And it is Ralph's two fervent speeches near the end that are most responsible for the play's reputation as a musty, melodramatic relic of the 1930s political naïveté - and a symbol of the Marxism that Odets and others $[\ldots]$ embraced in their youth, then later rejected (and were punished for) in the McCarthy era. (57)

Berson and Brooks are not alone in their reservations concerning the play, especially the play's ending. In his otherwise overtly positive study of the play, scholar Jonathan Krasner questions "whether Ralph has the stamina to follow up on his rhetoric" as "The evidence that Odets presented is conflicting" (14).

Odets' ending is perhaps so problematic because it attempts to impart optimism amidst great misfortune. Throughout Awake and Sing!, Odets is clearly focused on the impact of the Great Depression on American families. The Bergers are originally a middle class family, and as such they "were especially vulnerable to the threat and stigma of income loss" (Liker and Elder 345). Odets examines the economic disaster's impact on each character in the household, from the idealistic grandfather, to the ineffectual father, to the image-focused mother, and the struggling young adult children. In doing so, Odets also uses the family members as a means to demonstrate the stress the Depression placed on the middle-class family as a structural unit, specifically the impact on marriage, as the Depression was known to strain marriages "through (1) negative interaction patterns on 
financial matters and (2) the diminished stability of men" (Liker and Elder 354). As this chapter will explore, that "diminished stability of men" put the pressure on the women of the family as they were faced with either maintaining their remove from the economic sphere for the sake of their middle class image (the Bergers) or entering (and/or expanding) upon their role in the workforce (the Youngers).

The Social Drama

The Great Depression can itself be seen as a type of social drama. The stock market crash serves as one of the most memorable breaches in American history via the "stock market loss of over thirty billion dollars in the few weeks between October 24 and November 13, 1929; the nearly 30 percent unemployment by 1933" (Rabinowitz 1). The ensuing crisis was long-lasting. While the "sides" people could take in the crisis were often more nebulous than the other defined social dramas in this study, they were present. Odets explores one of the most prominent "sides" encouraged by the Depression: the turn to the Left and Marxist philosophies. Such a leaning, for those who supported it, was also viewable as a redressive means, an attempt to restore order. The Second World War, with its accompanying economic prosperity and employment opportunities serves as the most visible resolution to the crisis, although present-day economists may argue for a more cyclical understanding of the market crisis.

What Odets offers is a microcosm of the social drama played out in the form of the Berger family. Jacob, the grandfather, represents the turn away from Capitalism and its "starvation wages" (72) and towards Russia, for "In Russia they got Marx" (73). Jacob's two children, Bessie and Uncle Morty, are Jacob's opposites and the die-hard capitalists of the play. Uncle Morty demonstrates his love of capitalism with his business acumen and his 
attempted shaming of his father for his Marxist ideas, referring to him as "Boob McNutt" (73). Bessie's obsession with money dominates her character as well as almost every word she speaks in the play. Bessie's husband, Myron, is absolutely ineffectual, the hard-working man who does not and cannot understand how the system, the country, and his family have changed and is thus quickly left behind. Jacobs's death/suicide (he either falls or jumps off the building's roof during a snow storm) pushes Ralph to reconsider his life, and he follows in his grandfather's vision, promising to "Get teams together" (unionize) at his job in order to "get the steam in the warehouse so our fingers don't freeze off" (Odets 97) before turning to bigger Marxist endeavors. Hennie, the daughter, is the romantic and the capitalist, as she eventually flees her loveless and forced marriage, abandons her child, and runs off to Havana with Moe Axelrod, the boarder and number-runner in the house who promises her "moonlight and roses" (98). Within the family, then, Odets shows how many processed the Great Depression and generated their own small social dramas in response to the massive historical breach.

\section{Play Summary and Production History: A Raisin in the Sun}

By far one of the most successful plays discussed herein, Lorraine Hansberry's Raisin tells the story of three generations of the African American Younger family who share the same Chicago apartment, "sometime between World War II and the present" (Hansberry, $A$ Raisin 22). All of the play's action takes place in two rooms of the home- the living room (which also serves as the dining room) and the kitchen. The story starts soon after the passing of the family patriarch (Walter Younger) as Mama (Lena Younger), the clear head of the household at the opening of the play, attempts to do what is best for her grown son (Walter Lee), his wife (Ruth), their young son (Travis), and her daughter (Beneatha), who all 
live in the cramped apartment. The family threatens to disintegrate as they await the $\$ 10,000$ insurance check from Walter's death. Mama wants to buy a house for her family, an idea supported by Ruth, who learns she is pregnant with a second child. Beneatha wants to finish college and attend medical school, but she is distracted by her two suitors, George Murchinson and Joseph Asagai. George is rich but uninterested in her desire to continue her education. Asagai, a Nigerian student, supports and challenges her ideals and dreams in a way Beneatha finds both perplexing and desirable. As Beneatha struggles to find her identity, Walter Lee also fights to find his way; he wants to take control of the money and open a liquor store with two friends. When Mama puts a down payment on a home in a white neighborhood and Walter Lee loses the remainder of the money to a scam artist, the family's unity is again threatened by their loss, anger, and disappointment. The play ends on a potentially positive, albeit uneasy, note as the family heads out to occupy their house without additional financial support and against the wishes of the white neighbors who have tried to buy them out via the figure of Mr. Lindner, head of the local "Improvement Association" (Hansberry, A Raisin 114).

Raisin had a significant original run on Broadway. The first finished (and staged) play by Hansberry, it ran from March of 1959 until October of that same year at the Ethel Barrymore Theatre; the play then moved to the Belasco Theatre where it ran for another eight months. All told, the play ran for a total of 530 performances ("A Raisin in the Sun"). Raisin was the first play by an African American woman to be produced on Broadway, and it won the New York Drama Critics' Circle Award for Best Play (Carter 42). Part of the play's financial success had to do with the support it received from the African American community. As James Baldwin wrote: 
I had never in my life seen so many black people in the theater. And the reason was that never before, in the entire history of the American theater, had so much of the truth of black people's lives been seen on the stage. Black people ignored the theater because the theater had always ignored them. (Baldwin qtd. in Hansberry, To Be Young xviii)

The play has been revived countless times, including a 70-show run off-Broadway in 1986, an 88-show Broadway run in 2004, and a scheduled 2014 Broadway revival (“A Raisin in the Sun"). A review of Hansberry's papers, currently held at the Harlem Branch of the New York Public Library, reveals hundreds of requests for permissions to stage performances around the country, and around the word, at colleges and community centers, as well as programs and notes from productions in England, Ireland, France, South Africa, the Soviet Union, Israel, Czechoslovakia, Yugoslavia, Japan and Poland. In 1973, Hansberry’s exhusband and literary executor helped turn the play into a highly successful (847 shows) Broadway musical ("Raisin"). The play also spurred two film versions, one in 1961 starring much of the original stage cast, and one in 2008, starring the cast of the 2004 revival, including Sean "P. Diddy" Combs and Phylicia Rashad.

"Black" or "Universal"?

The play has been the object of tremendous popular response and scholarly criticism since its original production. Some of the greatest sources of disagreement, however, concern the intended audience of the play, the intended message of the play, and the meaning of the final scene. Critics and audiences alike have long argued over whether Hansberry's drama is a "Negro play" (Hansberry qtd. in Robertson X3) or a piece that "contains universal and universally American themes" ${ }^{, 2}$ (Washington 110). Robert Nemiroff, Hansberry’s exhusband and literary executor, argues that any desire to remove race from the play is to

\footnotetext{
${ }^{62}$ Of course, this use of "universal" and "universally American" seems to indicate "white."
} 
"substitute, for the what the writer has written, what in our hearts we wish to believe" (original emphasis; 8). Hansberry's own description of the play has been used to support the concept of the play as non-racial and universal: “this wasn't a 'Negro play.' It was a play about honest-to-God, believable, many-sided people who happened to be Negroes" (qtd. in Robertson X3). And yet, Hansberry's frustration is likely aimed at the consistent efforts of the time to note her accomplishments despite her race, rather than her attempts to remove race from her play, which clearly deals with the ever-present racism inherent to modern America. ${ }^{63}$ In perhaps a clearer synopsis of her own work, Hansberry wrote about her work in a letter to her mother, dated January 19, 1959:

Mama, it is a play that tells the truth about people, Negroes and life and I think it will help a lot of people to understand how we are just as complicated as they are - and just as mixed up — but above all, that we have among our miserable and downtrodden ranks - people who are the very essence of human dignity. That is what, after all the laughter and tears, the play is supposed to say. I hope it will make you very proud. (Hansberry, Letter 1959)

There is no removing of race from the play for Hansberry, but she is ultimately writing about "human dignity."

Much of this contention concerning audience feeds into questions of message in Raisin. For those especially concerned with making this play not about race (or those who are unused to being faced with questions of race), the play tends to represent a family succeeding against the odds. For other critics, Hansberry's play represents a particularly African American fight for equality and justice in a particularly unequal and unjust society.

${ }^{63}$ Hansberry addressed this concern succinctly and directly when asked by an interviewer how she responded to people exclaiming that Raisin "is not really a Negro play" but is instead "a play about people": "Well, I hadn't noticed the contradiction because I'd always been under the impression that Negroes are people" (original emphasis; Hansberry, To Be Young 113). 
Ossie Davis criticizes American audiences for viewing this play without simultaneously viewing its criticisms of race and inequality:

Some people were ecstatic to find that 'it didn't really have to be about Negroes at all!' It was, rather, a walking, talking, living demonstration of our mythic conviction that, underneath, all of us Americans, color-ain 't-gotnothing-to-do-with-it, are pretty much all alike. People are just people, whoever they are; and all they want is a chance to be like other people. (399)

Such a reading, for Davis and for writers such as Amiri Baraka, misses the point of Raisin and allows audiences to miss the intrinsic criticism of American society in the play: "We missed the essence of the work - that Hansberry had created a family on the cutting edge of the same class and ideological struggles as existed in the movement itself and among the people" (Baraka 19). Ironically, then, what makes Raisin so popular and long-lasting-its appeal to the masses of all races - is also what allows for many audience members to, whether by choice or ignorance, ignore many of the main points of the play.

Having taught Raisin, to over 40 community college students in Pennsylvania in multiple sections of Composition ${ }^{64}$ (the majority of whom were white, ages 18 through 60), I used the opportunity to ask students what they knew about the play and the time period ${ }^{65}$ before they read or viewed Raisin, and I asked follow up questions regarding their interpretation of the text before we had significant conversations about the historical and

\footnotetext{
${ }^{64}$ I generally used the written version of the play with my students, but I did once, in a shortened summer version of the class, use the $1961 \mathrm{film}$, which is remarkably close to the published text.

${ }^{65}$ Students were asked three sets of basic starter questions: 1) Have you ever read or seen $A$ Raisin in the Sun? What do you know about it? 2) Have you ever heard of Lorraine Hansberry? What do you know about her? and 3) What do you know about housing restrictions for African Americans, particularly in the 1950s?
} 
social background of the text ${ }^{66}$. Of the 42 students who responded anonymously to the prereading questions, only seven had ever read or seen Raisin previously, and only two had heard of Lorraine Hansberry. Students' knowledge of the living conditions for African Americans was also extremely limited; most responded that they had no knowledge of the time period. Others noted that they thought housing restrictions were probably "really bad" during the 1950s (qtd. in Malburne-Wade, 2010-2012). One student simply wrote "Separate but equal," while another wrote "segregation" and a third noted that s/he thought "that there were unfair rules in the South" (qtd. in Malburne-Wade, 2010-2012). One student was able to provide substantive detailed context regarding racial segregation and poor housing conditions.

Unsurprisingly, these students' lack of context significantly altered their understanding of the play itself. Of the 42 respondents who completed the postreading/viewing questionnaire, 19 viewed the play as distinctly about the African American experience, while 14 viewed it as a universally American experience, and 9 viewed it as "both," which was not a provided option on the questionnaire (Malburne-Wade, 2010-2012). Those who argued for Raisin as a play about the African American experience tended to stress the race-based struggles the family endured in their summaries of the work. They were more attuned to the social forces at work in Hansberry's writing, as they noted this was a "struggling family [that] tryes [sic] to make a home and a living in a white world" (qtd. in Malburne-Wade, 2010-2012) and argued that the play was about "a black family with dreams

\footnotetext{
${ }^{66}$ I asked students to respond to four sets of response questions: 1) How would you summarize the plot of A Raisin in the Sun? What is it about? 2) Do you think Raisin is a political play? Why or why not? Is it trying to change or challenge opinions? Regarding what? 3) Critics have said that Raisin is a play about the African American experience; other critics argue that Raisin is about the American experience generally. What do you think? and 4) Does this play/film have a happy ending? Why or why not?
} 
and who want to better themselves. They think the money is the way to accomplish this, but after losing it all they learn that their beliefs and hard work is [sic] what will get them there" (qtd. in Malburne-Wade, 2010-2012). Those who viewed the play as more universal tended to describe the play in more general terms, noting that the play "is about the struggles the family faces, and how they overcome them" (qtd. in Malburne-Wade, 2010-2012). Clearly, for these students, like the critics and public they are unintentionally modeling themselves after, their interpretation of the intended audience affected the message they took away from the play upon their first reading or viewing.

Nearly all of the respondents viewed the ending of Raisin as a happy one before our classroom discussion. Yet the ending of Raisin, which shows the Youngers setting out to occupy their new house in a hostile, white neighborhood after losing the vast majority of their inheritance (and their financial safety net), is clearly problematic (a fact all students understood by the end of our classroom discussion). A reader with appropriate historical context will realize the precarious position the Youngers find themselves in, especially given that "white suburbanites routinely engaged in acts of terrorism to prevent the settlement of African Americans in their neighborhoods" as they "met breaches in the color line with a guerrilla war of death threats, property destruction, and physical violence" (Wiese 100). This hopeful-yet-problematic ending, while often receiving less negative attention than Odets' ending, is, as I will argue more fully in the next section of this chapter, crafted to mirror Odets' problematic ending.

The Social Drama

Like Odets then, Hansberry is responding to the historical moment in which she was writing, yet Hansberry's historical moment also includes Odets' work. Hansberry is certainly 
focused on what Amiri Baraka calls "concerns I once dismissed as 'middle class'—buying a house and moving into 'white folks' neighborhoods," but as Baraka notes, these concerns are "actually reflective of the essence of black people's striving and the will to defeat segregation, discrimination, and national oppression" ${ }^{, 67}$ (19-20). Put more succinctly, "There is no such thing as a 'white folks' neighborhood' except to racists and to those submitting to racism" (original emphasis; Baraka 20).

Beyond housing, however, Hansberry also was concerned with the overall economic instability present in the African American community. The Younger family, like many African Americans of the time period, suffered from an economic Depression well after the Great Depression officially passed. As sociologists Walter R. Allen and Reynolds Farley have noted, "race and economic status are inexorably linked in this society" and "Shifts in the society's economic base coupled with historical (and contemporary) patterns of racial oppression explain the disproportionate concentration of blacks in the underclass" (277). Thus, while Odets was clearly concerned with the fate of the middle class during the Great Depression, Hansberry strives to make her audience painfully aware of the fact that "working-class families were more economically vulnerable," even after the U.S. economy officially rebounded (Liker and Elder 353).

The Youngers' small apartment where all able male and female family members work and contribute, with the exception of Beneatha who is in college to further advance herself

\footnotetext{
${ }^{67}$ Many have noted the autobiographical element of Hansberry's play. When Hansberry was a child, her father bought a house in a "white neighborhood" (Hansberry, To Be Young 20). The family faced years of abuse in the forms of "howling mobs" while Hansberry herself was "spat at, cursed and pummeled in the daily trek to and from school" (Hansberry, To Be Young 21). Her father took the fight to court along with the NAACP and won, but Hansberry alludes to her father's subsequent "early death as a permanently embittered exile in a foreign country" that did not fully accept him or his family (To Be Young 21).
} 
and her family, is indicative of the economic pressures on the family. While Odets gives us Bessie who, while not employed outside the home, wails that she "works like a nigger" for her family, Hansberry offers us a family where all the women actually work to sustain their family's well-being (Odets 85). It is no coincidence that Hansberry, performing an active criticism of American economic disparity and Odets' concept of what economic struggle actually looks like, uses a hard-working, underemployed, African American family as her centerpiece.

\section{African American and Jewish Relations}

Hansberry's use of Odets' work as part of the literary and historical predecessors against which she is writing brings to bear the question of Jewish and African American relations during the middle of the twentieth century. The Great Depression strained already problematic relationships between the communities as "At the height of the Great Depression almost 25 percent of the American labor force was unemployed; the black figure was double that" (Greenberg 49). Comparatively, "Twelve percent of Jews lost their jobs" while "Many more Jews were underemployed," but "the community's economic recovery occurred more quickly than that of most other groups" (Greenberg 49). To exacerbate the impact of the Great Depression on African American and Jewish relations, Cheryl Lynn Greenberg notes that "Black domestics seeking day work stood on street corners in the Bronx; many of the housewives who picked them up were Jews" (59). It is important to note that while the Youngers never mention religion, both Mama and her daughter-in-law Ruth work as domestics in white homes in Raisin.

This strain was not due entirely to economics, however. Greenberg emphasizes that while it would have been conceivable — and likely beneficial—-for the groups to work 
together as two minorities seeking similar rights, such was rarely the case. She outlines several reasons for this lack of cohesion and cooperation, including the group-specific focus of both African Americans and Jews, and the fact that the "sense of a shared historical experience with oppression was a limited and often theoretical one, diluted by Anti-Semitism on one side and racism on the other" (Greenberg 45-46).

James Baldwin commented on this tension in "Negroes Are Anti-Semitic Because They're Anti-White," arguing "One does not wish, in short, to be told by an American Jew that his suffering is as great as the American Negro's suffering. It isn't, and one knows that it isn't from the very tone in which he assures you that it is" (741). For Baldwin, "The Jew is a white man, and when white men rise up against oppression, they are heroes: when black men rise, they have reverted to their native savagery" ("Negroes Are Anti-Semitic," 742).

It is unlikely that Hansberry carried as strong a distrust of Jews (and her husband, Robert Nemiroff, was Jewish), but she certainly was attuned to the discrepancies between the minority groups. Amidst Hansberry's personal papers were notes she kept for an article on the trial of Nazi Officer Adolf Eichmann (written as “Eichman” in Hansberry's notes) who was tried in Israel for his role in the Holocaust. Hansberry notes that the "African continent lost one hundred millions of its people" during the slave trade and "it is well to remember that even the Nazis hardly outdid the sheer sadism and bestiality which was racked up during that epoch" ("Notes for an Article"). Nonetheless, Hansberry was personally touched by Eichmann's trial: "For me, there is a strong and powerful current of justice in the fact: A representative figure of Nazism. Tried on Jewish soil. Under Jewish justice. By Jewish judges. I am moved by the thought of it. It is about time" (original emphasis; "Notes for an Article"). This powerful moment for Hansberry is marked, however, by the lack of such a 
moment for African Americans: "No one, to my knowledge, has ever paid reparations to the descendants of black men; indeed, they have not yet really acknowledged the fact of the crime against humanity which was the conquest of Africa. But then, history has not been concluded either, has it?" (original emphasis; Hansberry, "Notes for an Article"). Unlike Baldwin, Hansberry does not appear to aim her frustration directly at the Jewish population, and her anger is tinged with hope. Nonetheless, Hansberry's Raisin is acutely aware of the chasm between the treatment of (white/Jewish) middle class families and (black) working class families.

Hansberry again revisited this comparison (and again with far less vitriol than Baldwin) when she responded to a 17-year old high school boy who wrote to her in 1962 to ask her more about her views on race relations. Hansberry writes:

I suppose that at the heart of my views of the 'Negro question' in the United States is the recognition that it is not a problem of random social discrimination against 'colored individuals' here and there but, in fact, a historical oppression of an entire people. That is a difference which may not seem clear at first reading; what I mean to say is that, for instance, the Jewish people in the United States are still discriminated against, as indeed are many other American minorities. [....] But the Negro people, as a whole people, are forcefully excluded from virtually everything which we may consider the mainstream of the economic, political and social fabric of our nation. (Hansberry, Letter 1962)

For Hansberry, while she recognizes the negative effects of oppression at all levels, there is certainly a tangible difference between individualized and ritualized discrimination.

There are, therefore, numerous social dramas at play in Hansberry's work. The continued segregation of housing in Chicago and beyond, the continued economic peril of the working class - particularly among African Americans, and the underlying tensions between minority groups all operate within this drama. These are large, historically significant social dramas, and not ones where resolution is easily achieved (and indeed economic disparity 
between races and classes is still very much a relevant issue). And yet, as this chapter's comparison of Awake and Sing! and Raisin will demonstrate, they are nonetheless the issues for which Hansberry attempts to offer redress.

\section{Acknowledging and Exploring the Liminal: The Relationship between Awake and Sing! and $A$ Raisin in the Sun}

Acknowledging the Liminal

Since the debut of Raisin, there have been a number of critics who have acknowledged the relationship between Awake and Sing! and Raisin, but these references have generally been made in passing. ${ }^{68}$ In three separate articles, Gerald Weales acknowledges the connection between Odets and Hansberry. In his 1959 "Thoughts on $A$ Raisin in the Sun," Weales makes three references to Odets and his play. Highly critical of Raisin, Weales notes, "If the set suggests 1910 [...], the play itself —in its concentration on the family in society—recalls the 30's and Clifford Odets" (Weales, "Thoughts" 528). Within the same article, Weales comments on one of the play's positive elements, its dialogue, noting, "the words have the ring of truth that one found in Odets" (Weales, “Thoughts" 529). Finally, in a discussion of Mama Younger, Weales appropriately notes "She is a sentimentalized mother figure, reminiscent of Bessie Burgess [sic] in Awake and Sing, but without Bessie's destructive power" (Weales, "Thoughts" 529). Weales also wrote about Raisin in his 1979 chapter, "Drama," found in the Harvard Guide to Contemporary American Writing, in which he again argued for macro similarities between the plays:

\footnotetext{
${ }^{68}$ Hansberry's play has been more often compared to Theodore Wald's Big White Fog and Sean O'Casey's Juno and the Paycock, the latter of which was an admitted source of inspiration for Hansberry as O'Casey was one of her favorite dramatists. Neither of these plays, however, share the same direct similarities with Raisin that one sees in Awake and Sing!
} 
Its plot, hinging on accident (the theft of the insurance money), suggests the realism of the 1920s and 1930s-George Kelly's Craig's Wife and Clifford Odets's Awake and Sing! to take two very different examples - in which an artificial plot device becomes a valid mechanism for the testing of the protagonist. (397)

Finally, Weales returned to this overlap between the dramas in a 1987 article on Odets.

While he acknowledges that Hansberry seemingly never discussed Odets' impact on her own writing, he is nonetheless "struck by the hovering presence of Odets" in Raisin ("Clifford's Children" 270). Acknowledging that the families in both plays seek forms of escape, Weales sees the main connections between the two plays, once again, as large-scale similarities, and intrinsic to "the family setting" and "central action" of each play ("Clifford's Children 271). Weales is careful, however, in this article, to also note the differences in each play.

In 1961, Kenneth Tynan referenced the connection between the plays, but his commentary is both briefer and less defined than Weales'. In a short discussion of Raisin, its plot, and Tynan's own enjoyment of the drama, the critic inserts one seemingly unrelated sentence: "I was not present at the opening, twenty-four years ago, of Mr. Odets' Awake and Sing, but it must have been a similar occasion, generating the same kind of sympathy and communicating the same kind of warmth" (Tynan 309). While vague, Tynan appears to be commenting, like Weales, on macro-level and generalized similarities between the two works.

In an interview with Hansberry, the published transcript of which appeared in American Theatre, Studs Terkel makes another passing reference to Odets. Hansberry discusses the lack of a central character in Raisin as "a weakness of the play" (Terkel 41). Terkel immediately asks her "Is this really a weakness? I'm thinking of Clifford Odets' Awake and Sing. There was no central character in this excellent play of a Jewish lower 
middle-class family" (Terkel 41). Hansberry seemingly deflects the question in her response, stating, "Well, obviously, when you start breaking rules you may be doing it for a good reason" (Terkel 41). While the context suggests Hansberry is referring to the lack of a central character, one could also note that she is, obliquely, referring to breaking the rules by revising the work of her predecessor. Similarly, Hansberry received a personal letter from "Norma and Joe" (last name illegible), in which the writers note that Hansberry's Raisin "will be doing the same for the coming era as did the first Clifford Odets' plays almost a quarter of a century ago. Some one compared it the other night with 'Awake and Sing'. By this is meant, I think, that you have brought the story of a contemporary Negro family to the public in terms of some universals..." (Norma and Joe). Like Terkel, the letter writers speak in macro-level connections between the texts, rather than pointing to more specific (and pervasive) connections.

Two critics have stressed a specific theme they found repeating in the dramas. C.W.E. Bigsby argues, "Although she [Hansberry] is as antipathetic towards a life printed on dollar bills as Odets had been, it is clear that the spiritual regeneration of the Younger family is ultimately contingent on a ten thousand dollar check, for it is only the money which makes it possible for them to challenge the system under which they have suffered" (159). Journalist Malcolm Johnson, in a review of the 2004 performance starring Sean Combs, points out the same connection: “'A Raisin in the Sun' takes some of its ideas from Clifford Odets' 'Awake and Sing': 'life shouldn't be printed on dollar bills"” (D1). Both critics rightfully argue that Odets and Hansberry are pushing for the realization of life and value outside of money, although both fail to note that what Odets and Hansberry actually valued was quite different, as will be discussed in the following side-by-side reading of the two dramas. 
Some critics have been far more critical of the connections between the two plays, seeing it as a significant detriment to Hansberry's work and creativity. Allan Lewis sees Hansberry's work as little more than unoriginal copy:

In Odets' plays, the Depression, as a special moment in American life, is evident in every scene. Today, the working class has risen to middle-class comfort, and Odets' former Bronx characters no longer have the same identification, save for the underprivileged and the oppressed minorities. Lorraine Hansberry's A Raisin in the Sun is an Odets drama with Negro replacements. (112)

In the same vein, Jordan Y. Miller finds the play to be more than just referential:

Consider: A play by a Negro about a contemporary Negro family called the Youngers, though introducing various problems complicated or even caused by the existence of their blackness, causes no more sensation than, say, the play about the Bergers who happened to be Jewish and happened to live during a crippling economic depression whom Clifford Odets wrote about in Awake and Sing some twenty-five years earlier. (159)

These critics have moved from a passing comment on the connection between the works to a dismissal of the revision.

In the epilogue of her work Negro Playwrights in the American Theatre 1925-1959, Doris Abramson makes a passing remark about Hansberry and Odets as she discusses the evolving genre of "social plays" (270). She acknowledges that many playwrights in the 1950s, including Arthur Miller, were "still writing in the tradition of O’Neill and Odets," and then goes on to call Hansberry's Raisin "a Negro Awake and Sing!" (270). In response to this assertion, critic Clayton Riley calls Abramson's work “patronizing nonsense” and alleges that her book is "absurdly defective in its assumptions" (329). For Riley, Abramson is "plantation-oriented" and has "thinly veiled contempt for plays and playwrights who could not live up to the standards she regards as the only important ones-those previously 
established by white artists" (329). Recalling Abramson's comment above, in which she calls Raisin “a Negro Awake and Sing!,” Riley asserts:

This, because Doris Abramson has no standard - no life - that is not controlled by norms established in the most racist terms, the most relentlessly white terms. As the book indicates, she deals in the past, when everything colored was an imitation dependent on the good graces of enlightened whites for an existence-let alone a life. She deals there, and still lives there. (330)

For Riley, Abramson's work, and specifically her words about Raisin, are unforgivable. While Abramson's work is decidedly marked by her times, and while her understanding of the relationship between Hansberry and Odets is seriously over-simplified, she is not wrong in seeing the connection itself.

None of these reviewers or critics has it quite right, however. These plays are connected by more than simply a family focus or loose idea, as some of the critics want to suggest. Neither is Hansberry simply substituting an African American family for a Jewish family. Much of the dilemma surrounding the exploration of the relationship between these two texts seems to involve either a fear of calling Hansberry unoriginal, or a desire to do just that. Of course, Hansberry's work is fully original: she does not simply rewrite Awake and Sing!. Indeed, she can be seen to have written the better play, one that invites more interpretations, more critical inquiry, and more emotional response; she also wrote the far more commercially successful — and best remembered—play.

Critics who feared the label of unoriginal for Hansberry may have been afraid to add to the weight already tied to a young, African American, female playwright in 1959 America. Indeed, when critics repeatedly mention, as Tynan did in his review of the play, that "this is the first Broadway production of a work by a coloured authoress, and it is also the first Broadway production to have been staged by a coloured director," it becomes clear why we 
have remained unable — or unwilling — to discuss Hansberry's relationship to Odets (my emphasis; Tynan 307-308). While Hansberry's success was groundbreaking due to her race and her gender, the continual need to stress both rather than simply acknowledging her as an artist becomes, at times, a way of categorizing and limiting her. Thus, for those who wish to support her work anything that, if not understood properly or fully, could tarnish those accomplishments, feels taboo.

As for Hansberry herself, her personal papers show very little of her thoughts on the comparisons between the two plays. In a 1959 article she published in The Village Voice, Hansberry acknowledges that many names, including "O'Casey and the early Odets were introduced for comparative purposes in some of the reviews," but she fails to comment any further on the comparison, instead noting that no one except Gerald Weales "discovered a simple line of descent between Walter Lee Younger and the last great hero in American drama to also accept the values of his culture, Willy Loman" (Hansberry, "Willie Loman" 7). While Miller was, by Hansberry's own admission, an influence on her work, it is the connection to Odets that permeates her work most thoroughly, whether she chose to discuss the matter at length or not. Hansberry did keep a photocopy of a New York Times which included both an opinion piece alleging that her work borrowed extensively from O'Casey and a published response from Hansberry herself in which she refutes the claim, acknowledging that any relationship between her work and O'Casey's rests "in the spirit" (Hansberry, "Mailbag" X3). More interesting and telling than Hansberry's published response, however, is a handwritten note in Hansberry's writing that is scrawled at the top of the photocopy in large letters: "Plagiarist! At last!!!” (Hansberry, "Mailbag” X3). One can assume that Hansberry could finally feel she "made it" when she was accused of plagiarism. 
In order to understand the full impact of Hansberry's play, however, including the social commentary intrinsic to her revisions, scholars must begin to explore the relationship between the works of Hansberry and Odets. Hansberry's ability to layer circumstances, emotions, and criticisms onto Odets' already politicized piece becomes a form of literary palimpsest. She has literally written her work on top of Odets' in a way which leaves the strands of the original resting just beneath the surface of her own text. The writing underneath is neither fully visible nor fully hidden from the audience-it remains partially visible for those who wish to discover it. And while Raisin is a strong play in its own right, it becomes significantly stronger once shown in relationship to its predecessor, both in terms of its artistic impact and social meaning.

Exploring the Liminal

In order to demonstrate the relationship and differences between the two dramas, the remainder of this chapter will actively compare the two plays side-by-side. The connections between the two plays make it clear that Hansberry was revising Odets as a form of criticism, both of his work and of the historical implications it calls forth. Indeed, part of what makes Hansberry's palimpsest so effective is her understanding of — and her ability to re-envisionthe strengths and weaknesses of Odets' Awake and Sing! Both families are dominated by controlling mothers; both plays have ineffectual male figures. Both plays revolve around the death of a patriarch and the money he leaves behind. Both plays involve a struggle between the dominant mother and the headstrong son regarding what to do with the inherited funds. Both plays focus on an unwanted pregnancy. Both plays have a misunderstood daughter with two suitors and in both plays, one of the suitors is considered a foreigner. Both daughters have names reflecting their status in the family, as Odets' hen-pecked Hennie 
becomes Beneatha, who is also called Bennie in the play. Both plays end positively but ambiguously. In much the same way as the other playwrights discussed here, Hansberry alters the details and creates a new story in an attempt to dismiss the power and the assumptions of the past.

\section{Exploring the Liminal: Physical Spaces}

The staging for both plays is decidedly similar. Odets' play tells the story of three generations of a lower-middle class Jewish family, the Bergers, living in the same small Bronx apartment home during 1935. The staging for the play is a "typically furnished" front room and dining room (Odets 40). Odets tells us in his description of the characters, "All [...] share a fundamental activity: a struggle for life amidst petty conditions" (Odets 37). Raisin could be described in much the same way, but set further in the future: three generations of the African American Younger family live in the same Chicago apartment. As in Awake and Sing!, all of the play's action takes place in two rooms of the home; in Raisin, those rooms include the living room (which also serves as the dining room) and the kitchen. Thus, while for the Bergers the kitchen, the working room in the apartment, is just off stage, it becomes a focal point for the Youngers. It also points to the smaller apartment in Hansberry's play: the Youngers do not have a formal dining room. Like the Bergers, the Youngers are struggling "amidst petty conditions." The "petty" conditions of the Depression era, however, as discussed earlier, exist for the Youngers well past the actual Depression. The relationship between the two time periods is clear: for African Americans, the end of the Depression was not the end of economic hardship. 


\section{Exploring the Liminal: Mother-Matriarchs}

Each of the households is headed by a strong female figure. In Awake and Sing!, Bessie clearly dominates the household as she embodies a disturbing but understandable reaction to the Great Depression. She exhibits a frantic need for control—over her family, over the family finances, and over public opinion of her family. She easily manipulates her husband, Myron, and attempts to control both her children—Hennie and Ralph—and her father-Jacob. Dogged by a constant fear of absolute poverty, Bessie hovers over all the characters in the drama, and her fanaticism is evident in her dialogue: "They threw out a family on Dawson Street today. All the furniture on the sidewalk. A fine old woman with gray hair" (Odets 43). Bessie is conscious, always, of the "fine old woman," public opinion, and the possibility of losing her home. She, of all the characters, shows the strain of the Depression as both her husband and her son have their working hours and pay reduced: "Ralphie took another cut down the place yesterday [....] What's gonna be the end? Myron's working only three days a week now" (Odets 61). There is no scene in which Bessie is not discussing the family's economic or social standing.

Bessie's domineering nature is not intentionally malicious; she possesses "a sincere concern for her family, albeit an overconcern" (Shuman 166). Her concern for her family, however, verges on making her a self-described martyr. She tells her daughter to get married — even before learning of her pregnancy—because "When I was your age it was already a big family with responsibilities" (Odets 44). Similarly, when speaking of Hennie's child, she tells her brother “a woman who don’t raise a family—a girl—should jump overboard. What's she good for?" (Odets 62). With no real understanding of what it would mean to have a life outside having — and controlling — her family, Bessie struggles to see a 
life beyond struggle itself as she berates her son: "Summer shoes you didn't have, skates you never had, but I bought a new dress every week. A lover I kept—Mr. Gigolo! Did I ever play a game of cards like Mrs. Marcus? Or was Bessie Berger's children always the cleanest on the block?! Here I'm not only the mother, but also the father. [....] If I didn't worry about the family who would?” (Odets 95). In her own mind, Bessie's sacrifices-her lack of new clothing, a lover, and social commitments outside the home - justify her treatment of her family, regardless of their desires or dreams. She challengers Ralph to "go out and change the world if you don't like it," but in reality, she sees no such change as truly possible (Odets 95).

Reading Bessie within the confines of her history makes her character slightly more sympathetic. The Bergers are barely maintaining a middle-class status - and their ability to maintain such a status despite the ravages of the Depression results primarily from the support of Bessie's successful brother, Uncle Morty. Bessie's fear for her family's future is well founded. As sociologists Jeffrey K. Liker and Glen H. Elder, Jr. have noted, "families not yet materially affected in 1930 [or 1935] suspected or knew they would soon face financial difficulties, and this anticipation and uncertainty created marital tension" (349). While the family is not yet suffering, the men are certainly underemployed and their position —along with Uncle Morty's position—remains vulnerable, leaving the family vulnerable. Because no one else in her family appears concerned with the financial stability of the family, Bessie bears the brunt—if not the entirety—of that stress. Ironically, she also remains the figure with the least control over the situation. Feminist writer Mary Inman wrote of married women like Bessie - those who have no control over their own destiniesin her 1940 publication In Woman's Defense: "She is dependent upon another for the very 
bread she needs to sustain life. Her life is not her own. Her time belongs to him [her husband]" (Inman 103). Bessie's attempts at control, then, become the reactions of a woman whose actions are limited by gender.

Bessie remains, however, with her self-aggrandizing and controlling behavior, a difficult character to respect. No doubt, Odets meant her to be unsympathetic because she is a bastion of capitalist thinking. In order to raise up Ralph at the end of the play, Bessie becomes one of the play's casualties. ${ }^{69}$ This move, however, remains difficult to digest. Few audience members or readers want to see the success of a movement—even a movement they believe in - at the expense of a family. Odets' portrayal, unfortunately, does not challenge or even acknowledge capitalism's subjugation of women. As Inman notes, “[...] ever since the overthrow of free tribal society woman's labor has successively enriched the chattel slave owners, the feudal lords and the capitalists, and to the acquisition by these owners of the value of her toil can be traced all the inequality and injustice she has known throughout the ages" (17). Odets' disregard for the mother figure increases the difficulties of this play, particularly for a female audience. Awake and Sing!, like movies of the same period, "show [s] by indirection and inference how nice and sane it is for the husband and father to rule the household by showing how miserable it makes everyone when a woman becomes a household tyrant" (Inman 40). Directly or indirectly, Odets sacrifices family, mother, and women to make his point.

\footnotetext{
${ }^{69}$ Jonathan Krasner views Bessie differently, noting that she is a representative of the "dominant Jewish mother," a hold-over from "the Yiddish theater" and "stock images of Jews in Western theater, dating at least as early as William Shakespeare's The Merchant of Venice" (3). Yet, while Krasner posits that Odets "effectively transplanted these stereotypes into an American milieu while adroitly avoiding reductionist character portraits," I argue that Bessie is in fact reduced in a way that is difficult to move beyond (3).
} 
Hansberry creates a similar figure at the center of her play in the form of Lena (Mama) Younger, but Mama manages to be both strong and adaptable. Ironically, Mama's strength comes from her situational placement, in much the way that Bessie's weakness derives from her time and place. Mama is African American and of the lower class; like many African Americans, Mama suffers from an economic Depression even after the Great Depression passes. Thus, Mama and her family become more concerned with day-to-day operations than maintaining a status quo of wealth, which also becomes a factor in the audience's sympathetic response to the family. While their level of poverty puts them in more dangerous social position - they have, in effect, less to lose and therefore less ability to survive additional economic hardships — they are also more resourceful. Mama works "like a dog every day"70 to keep her family functioning; her son and daughter-in-law also work outside the home, as did her husband (105). Yet, even more important than Mama's social status is her refusal to let financial concerns conquer her first priority: her family.

Mama's focus on her family inexorably connects her to Bessie Berger: like Bessie, Mama is a strong, central figure in her family's daily life. Also like Bessie, Mama is concerned with her family's moral well-being. Indeed, she will not stand for immorality in her household. When her daughter, Beneatha, asserts that she no longer believes in God"There simply is no blasted God — there is only man and it is he who makes miracles!"Mama slaps her across the face, demanding that she state "in my mother's house there is still God" (Hansberry, A Raisin 51). Similarly, faced with her daughter-in-law Ruth's unwanted

\footnotetext{
${ }^{70}$ Comparing Mama's statement that she works "like a dog every day," (105) when she does in fact work hard to support her family, to Bessie's statement that she "works like a nigger" for her family (Odets 85) does little to improve a reader's view of Bessie, and it certainly adds to the strength of Hansberry's revision as she illustrates what working for one's family actually looks like.
} 
pregnancy, Mama demands that her son, Walter Lee, prove his worth: “[ ...] I'm waiting to hear you talk like him and say we a people who give children life, not who destroys themI'm waiting to see you stand up and look like your daddy and say we done give up one baby to poverty and that we ain't going to give up nary another one...I'm waiting” (Hansberry, $A$ Raisin 75). Despite her influence, however, Mama's children—like Bessie's—seem to become people she can neither fully understand nor fully control.

Hansberry gives Mama the one thing Odets does not grant Bessie: adaptability. Mama re-evaluates her control over the inheritance in order to help her son feel like the man in the family. Even after Walter Lee loses much of the family's money in a scam, Mama manages to love and forgive her son—even if it means she must herself work harder and reconsider her dream of owning a house. She instructs Beneatha that the time to love somebody is not, in fact, when such love is easy. Instead, the time to love someone is "when he's at his lowest and can't believe in hisself 'cause the world done whipped him so! When you starts measuring somebody, measure him right, child, measure him right" (Hansberry, $A$ Raisin 145). Throughout the play, Mama continually strives to "measure" her children "right," even when doing so means changing her own views about success and failure. It is Mama's ability to adapt, her ability to recognize that "Yeah—-they something all right, my children...," that allows this family to survive both the economic and moral tests that begin to destroy the Bergers (Hansberry, A Raisin 150).

While Mama's adaptability, Hansberry suggests, partially derives from her race and class, Bessie's inflexibility also derives from her class—or at least her unquestioned belief in the class system. Unlike Mama, Bessie attempts to steal the money her father left to her son, enlisting the help of her brother, Uncle Morty, who tells Ralph that the money was left "In 
your name $[\ldots]$ but not for you" (Odets 92). As Ralph begins to stand up to Uncle Morty, Bessie crumbles. She alternates between blaming her brother-“Don't be crazy. It's not my fault"- and maintaining her own need for control over the money that does not belong to her-"A family needs for a rainy day. Times is getting worse. Prospect Avenue, Dawson, Beck Street—every day furniture's on the sidewalk" (Odets 93, 95). Faced with similar choices, Mama and Bessie make very different decisions, allowing the audience to side with Mama while struggling to understand Bessie.

\section{Exploring the Liminal: Problematic Male Figures}

Hansberry continues to create more complicated, three-dimensional versions of Odets' characters throughout Raisin, again correcting some of the difficulties in Awake and Sing! Odets includes two problematic male father figures in Awake and Sing!, Bessie's husband, Myron, and father, Jacob; neither offers substantial resistance to her domineering nature. Myron wanders in and out of scenes - and in and out of his life-without significant meaning or purpose. When he learns that one of his daughter's suitor's "hands got free wheeling," he not only fails to take action, he also fails to remain on topic when speaking about the matter: "I don't know...people ain't the same. N-O. The whole world's changing right under our eyes. Presto! No manners. Like the great Italian lover in the movies. What was his name? The Sheik...No one remembers?" (Odets 45). Myron's inability to enact change or stand up to anyone - even his wife — not only puts Bessie in the position to dominate, but it also makes him a moot and forgettable character.

Jacob attempts to resist Bessie's domination and her concerns with capitalistic sustainability, yet he too struggles to be heard. Espousing Marxist philosophy throughout the play, Jacob attempts to convince the family of another way of life. He is quickly shut 
down by Bessie, relegated to the position of dog-watcher for the family poodle. When Bessie arranges a marriage for pregnant Hennie in order to preserve Hennie's (and Bessie's) dignity, Jacob denounces her intentions to hide the pregnancy from the new fiancée: "This is a house? Marx said it—abolish such families" (Odets 55). Jacob's character, the voice of an alternative reason — but reason nonetheless — often seems overwhelmed by his role in the drama: he is the voice of revolution in a family overburdened by myopic needs for power and minute moments of control. Krasner reads Jacob somewhat differently, seeing his Marxist tendencies not as a desire for an altered future but rather "a yearning for an elusive and invented past, a form of escapism" (9). Regardless, in both readings, Odets charges Jacob with a weight any character would have difficulty carrying; his idealism has no positive outlet in the play.

Despite Jacob's idealism—or perhaps because of it—he remains largely ineffectual. Bessie ends his thoughtful and thought-provoking speeches by sending him to his room like a child: "Go in your room, Papa. Every job he ever had he lost because he's got a big mouth. He opens his mouth and the whole Bronx could fall in" (Odets 55). Jacob becomes, then, a form of the 1930s ineffectual intellectual. He believes in a radical philosophy but lacks the ability to enact any form of real change. Like many of the intellectuals of the period, Jacob may very well believe in the philosophy he espouses as a "solid diagnosis of the economic malaise" pervading the country (Robins 71). Yet Jacob's diagnosis has no tangible cure; he remains powerless. His theoretical (i.e.: non-active) dedication to Marxism does not allow him, in any way, to break Bessie's demeaning obsession with financial security.

Raisin corrects the problematic Myron/Jacob character by erasing him/them. Mama's husband - Walter Younger — serves as a combination of both Myron and Jacob. Yet, in a 
morbid (and somewhat ironically humorous) twist, Walter is as ineffectual in the play as Myron; Walter, however, is actually dead. Given the similarities between many of the characters in both plays, Hansberry's disposal of the father figure is notable; Myron/Jacob is so ineffectual that his equivalent never speaks, or even lives, in Raisin. Hansberry collapses Myron and Jacob - the ineffectual dreamers whose greatest contribution to the family often comes post mortem - into one person. Like Myron and Jacob, Walter dreams bigger than he can live, as Mama remembers him stating, "'Seem like God didn't see fit to give the black man nothing but dreams - but He did give us children to make them dreams seem worth while"” (Hansberry, A Raisin 45-46). Also like Myron and Jacob, Walter struggled with being the best contributor to the family. Whereas Myron and Jacob struggle financially or ideologically, however, Walter struggles morally: "God knows there was plenty wrong with Walter Younger - hard-headed, mean, kind of wild with women — plenty wrong with him" (Hansberry, A Raisin 45). Rather than flaunt Walter's weaknesses on stage, however, Hansberry removes them by removing Walter altogether.

Exploring the Liminal: the Children

There is "plenty wrong with" the children of both plays as well, but again, Hansberry removes some of these difficulties in order to create a stronger character base and a stronger social commentary. In Awake and Sing!, the burden of the play's hopeful ending rests on Ralph. Yet Ralph is, perhaps, too weak to sustain such responsibility. Ralph begins the play confused, searching, struggling for just a "chance to get to first base" financially (Odets 41). He resembles both a boy and a man as his desires are those of both child and adult: "I wanna make up my own mind about things...be something! Didn’t I want to take up tap dancing, 
too?" (Odets 41). Easily distracted, Ralph seems unable to carry the weight of the ending he is assigned by Odets.

Ralph's salvation, the audience learns, comes through his grandfather's guidance. Jacob hopes that his dreams will become a reality through his grandson, telling him: "Look on this failure and see for seventy years he talked, with good ideas, but only in the head. It's enough for me now I should see your happiness. This is why I tell you-DO! Do what is in your heart and you carry in yourself a revolution" (Odets 78). Ralph's "revolution" is a conundrum, however. He finds his voice when he stands up to his mother and Uncle Morty to claim the insurance money rightfully left to him, but he ultimately decides to leave that money to his family in order to follow what he believes is his grandfather's true legacy: “'Awake and sing,' he said. Right here he stood and said it. The night he died, I saw it like a thunderbolt! I saw he was dead and I was born! I swear to God, I'm one week old! I want the whole city to hear it — fresh blood, arms. We got 'em. We're glad we're living" (Odets 101). For Ralph, manhood comes when he leaves his family — and their financial strings — in order to strike out on his own. In doing so, however, Ralph leaves the one thing his grandfather wanted him to have, financial security, and with it, the capacity to escape his family.

Such an ending, leaving Ralph free from the theoretical burden of capitalism ${ }^{71}$, also leaves him without any clear direction or solid foundation. Christopher J. Herr notes, "The ending of Awake and Sing! [...] has been criticized as too hopeful for what has gone before" as "Ralph's awakening [can be seen] as implausible" (Herr 74). Indeed, the ending is

\footnotetext{
${ }^{71}$ It bears noting that while Ralph has freed himself from the familial and capitalistic fight for means, it also leaves him without any money himself, complicating further his ability to enact change when he lacks the ability to fully support himself outside the family home.
} 
complicated by the presence of Hennie. She, too, has been hen-pecked (as her name implies) by her mother, forced into marrying a man, an immigrant, she does not love when she becomes impregnated by a man who leaves her. As Ralph finds his wings, so does Hennie: she decides to abandon her husband, leave her son with her mother, and run off with Moe, the boarder whom she has evidently loved throughout the play. Yet, as Herr has noted, "Hennie's abandonment of her child is evidence that the paradise she seeks with Moe is tainted by self-absorption" (Herr 74). Problems of plausibility and problems of morality haunt Odets' ending, resulting in a forced sense of hope that seems ultimately destined to fail.

In Raisin, Hansberry puts the son, Walter Lee, in the position of as-of-yet-unachieved manhood as well. Walter Lee suffers not simply from an overbearing mother, however, but from wage labor poverty and systemic racism. Like Ralph, Walter Lee simply wants to get ahead, to make something of himself; he wishes to create a better life for his family out of the "big, looming blank space-full of nothing” that is his future (Hansberry, A Raisin 73). Walter Lee, in a sense, has more to lose, however. He has a wife, a son, a mother, and a sister to support. Unlike Ralph, Walter Lee will not likely be able to leave his mother's house as neither mother nor son would be able to remain fiscally solvent. Walter Lee must, then, find another way to "tear down the economic and social wall built around him and his family by a white racist society" (Carter 161). He must negotiate both capitalism and racism in order to find his manhood.

Whereas Ralph attempts to break free to search out his own destiny as a man in the world, then, Walter Lee struggles to become a better man, a better husband, and a better father in the world he knows. Walter Lee almost fails in his mission, losing the money his 
mother gives him to manage in a botched liquor store purchase, but he too has a moment of redemption in the play. Walter Lee insists he will sell the house his mother bought with part of the inheritance back to the white community that does not wish to house black residents. Ultimately, however, Walter Lee cannot accept money that serves, as Mama states, "as a way of telling us we wasn't fit to walk the earth" (Hansberry, A Raisin 143). When faced with the reality of his choice, Walter Lee cannot sell his family's pride in front of his own son: “...we have decided to move in to our house because my father—my father—-he earned it for us brick by brick" (Hansberry, A Raisin 148). Ralph chooses a future by electing a future of hard work, independence and pride; Walter Lee makes the same choice. Walter Lee's choice, however, seems more tangible. He chooses his family and their needs over a revolutionary spirit. Hansberry's creation of a three-dimensional, realistic family makes that choice an option.

Hansberry also revises the role of the sister in order to remove much of the shadow of immorality from Raisin. Beneatha, called "Bennie" by the family, also possesses a name that suggests subordination or secondary importance. ${ }^{72}$ Bennie, like Hennie, must choose between two men who love her. She ends the play preparing for the possibility of leaving the country with the man she loves_-Joseph Asagai. Like Moe in Awake and Sing!, Asagai offers Beneatha a challenge - something both women crave. Yet Beneatha is not married by

\footnotetext{
${ }^{72}$ Hansberry wrote of her decision to name Beneatha in a letter to Professor Peter Buitenhuis in Yale's American Studies Program. Noting that the African American tradition of using "colorful names for offspring which seems to be the inclination of newly removed peasantries the world over, has been an unending source of commentary on what some consider our 'folksy' ways"' (Hansberry, Letter, n.d.). Hansberry thus uses Beneatha as her "own personal joke," a character who "when the laughter dies away, speaks the stuff of truth" (Hansberry, Letter, n.d.). Thus, it is Beneatha who "speaks (gropingly it is true) of a need for order in this world of ours. In that sense her desire to be 'a doctor' is a simple symbolic statement of what I hope and believe mankind will ultimately worship in place of the old and useless Gods—-science" (Hansberry, Letter, n.d.).
} 
the end of the play, and she has not relinquished her desire for a career and marriage, an important victory for Hansberry's character. Odets represents women as capable of supporting themselves only via their ability to find (or coerce) a husband; Hansberry pushes her female characters into striving for more nuanced and advanced positions. And, while Beneatha's desire for a career could be linked to her blue-collar status, her desire to be a doctor shows both her belief in her own intelligence and her belief in upward mobility for African American women.

Part of Beneatha's freedom must be linked to Hansberry's choice not to burden her with the unwanted pregnancy that limits Hennie. In Raisin, it is Walter Lee's wife, Ruth, who becomes pregnant with her second child but fears that the family lacks the resources to care for another life. Given the 24-year time difference between Awake and Sing! and Raisin, it is perhaps unsurprising that Ruth considers an option Hennie does not have: abortion. The abortion never happens, however, as Ruth decides to keep her child. Thus, while both Ruth and Hennie face the possibility of life without their children, Raisin empowers the family to ultimately see the baby as a blessing, not a burden Exploring the Liminal: the Suitors and the Foreigners

Hennie's abandonment of her child in order to set out with Moe makes it difficult to relate to her as a character. But her treatment of her husband (whom she also abandons) is equally disturbing. Once Hennie's mother learns that Hennie has been impregnated by a man who has skipped town and cannot be found, she declares "Tomorrow night bring Sam Feinschreiber for supper" (Odets 54). Hennie instantly understands the implications: "I'm not marrying a poor foreigner like him. Can't even speak an English word. Not me! I'll go to my grave without a husband" (Odets 55). Sam, the audience learns, has been "only three 
years in the country" (Odets 55). Despite Hennie's revulsion, she is engaged to Sam within days, and he is convinced, rather quickly, that the child she carries is his. Throughout the play, Hennie treats Sam with constant derision, talking about him behind his back and insulting him to his face. She tells her uncle, "I never had anything from life. Sam don't help" because he brings home "Twenty-one [dollars] a week" and "a nigger don't have it so hard" (Odets 67). Eventually she tells Sam that the child is not his, but Bessie convinces Sam she is only joking. Nonetheless, Sam wakes up in fear, worrying that "Hennie could kill [him] in the bed" (Odets 79).

Hennie's other suitor, whom the audience learns she slept with long before she married Sam but who is not the father of her child, is the number-running boarder, Moe Axelrod. Moe always has money, unlike Sam, and he tells Hennie that he was "the first guy. Part of your insides. You won’t forget. I wrote my name on you-indelible ink" (Odets 97). Hennie, realizing it is true, abandons Sam and her child for the man who offers her “moonlight and roses" (Odets 98).

Beneatha is also pursued by two suitors, one who has significant means and the other a foreigner, but in Hansberry's work, Beneatha comes to love the hard-working foreigner over the man with money. In Hansberry, George Murchinson comes to replace Moe, but his money comes from his family, not illegal activity. George, however, wishes Beneatha would not talk so much: "You're a nice-looking girl...all over. That's all you need, honey" (Hansberry, A Raisin 96). When Beneatha tires of George, Mama, unlike Bessie, fully supports her daughter's decision.

It is Joseph Asagai, the Nigerian, who ultimately attracts Beneatha. Unlike Hennie, who pushes against the "foreign-ness" of Sam, Beneatha is drawn to it, learning more about 
his culture, family, dress and music. It is Asagai who tries to convince (and may well have convinced, by the end of the play) Beneatha to leave the United States in search of her future as he urges her to marry him and come to Nigeria to become a doctor. Thus, while Odets has Hennie show disdain for her heritage as she tries to distance herself from Sam in exchange for the allure of romance and money, Beneatha turns away from the easy promise of stature and comfort and toward a part of her heritage, albeit a much further removed heritage: Africa.

Exploring the Liminal: Questionable Endings

This is not to say that there is nothing weighing down the ending of Raisin. As the play concludes and the family heads off to a new home in an unwelcoming white neighborhood, with no funds left to help them make (likely high) mortgage payments, the audience's relief at seeing their united front must, with careful thought, waver. They are, as Hansberry's literary executor and ex-husband Robert Nemiroff notes, "on the brink of what will surely be $[\ldots]$ at best a nightmare of uncertainty" (original emphasis; 11). Indeed, the first draft of the play ended with the family "sitting in the dark, armed, awaiting an attack by hostile whites" (Carter 41). The fully negative ending had to give way to the current ambiguously positive ending, however, in order to retain the liminal via the suggestion of Odets' play.

The one significant difference between the endings, however, rests in the position of the Younger family versus the position of the Berger family. At the end of Awake and Sing!, Jacob is dead; Ralph is setting forth on an ambiguous journey; Bessie has created a rift among herself, her son, and her brother; and Hennie has abandoned her child and left for Cuba. For Odets in this play, the family unit represents the seat of capitalism and as such, at 
least in its current cultural form, it has to be disrupted, indeed fractured, in order to move forward. Contrastingly, at the end of Raisin, the Younger family sets forth as a cohesive unit. Walter Lee has assumed his position as the head of the family, Ruth has decided to keep her child, Mama is laughing with her children, and Beneatha is looking forward at her own family and future. While an educated reader knows that this family faces huge challenges, they nonetheless face them as a unit. The family is not part of the ideological problem for Hansberry as it is for Odets. Indeed, Hansberry celebrates the family as the sole means of hope. Whereas Ralph sets out alone, the Youngers set out together.

Nonetheless, Raisin's questionably positive ending offers some of the strongest social criticism available in the play. Hansberry offers characters who believe that with hard work and dedication, they can achieve the American Dream. Inman illustrates what such a dream means for parents such as the Youngers:

Some parents dream all their lives of attaining security and failing they often become an easy prey to owning class propaganda and their dreams live on in their child, and they think if only they can urge and goad him on that he and at last they, through him, can escape at least in their old days, the insecurity and drudgery they have known. (161)

Hansberry painfully displays that such a dream, while admirable, will likely forever remain just outside their grasp; they are held back by the restrictions of race and class. In his 1974 article, "Lorraine Hansberry as Ironist: A Reappraisal of A Raisin in the Sun," Lloyd W. Brown calls this realization the "ultimate irony" of Raisin: "[...] despite all the hallowed myths of change and the cherished dream of ideals of human fulfillment, American society allows far less room for optimism about real change than do the despised societies of the socalled underdeveloped world" (246). The Youngers may remain together, but they will also be repressed, as a unit and individually, by a surrounding racist society. 
Thus, while the Bergers become a negative, corrupted family that Ralph must abandon to find hope through revolution, the Youngers are actually the family more oppressed by capitalism and racism. Ultimately, Hansberry's portrayal is both more subtle and more complicated, for it runs under every aspect of American society and even the adaptable, belief-driven families will be driven to either destruction or revolution. Such a revolution will not be for a new system, as we see in Awake and Sing!, but rather for a fulfillment of the promise of the existing system. Those two very different revolutions are evident in the final characters of both plays: Uncle Morty and Karl Lindner.

Exploring the Liminal: the Capitalists

Odets describes Uncle Morty as a "successful business man," yet "Something sinister comes out of the fact that the lives of others seldom touch him deeply" (Odets 38). His generosity comes at a price as "he wants others to be aware of it" (Odets 38). Even though his name is reminiscent of the French word for death (mort), Odets shows him as an often insensitive, overgrown child. He "sees every Mickey Mouse cartoon that appears," even referring to his new nephew as "the Mickey Louse" - the child who "sleeps_-gets it in the mouth—sleeps some more" (Odets 38, 62). Given Uncle Morty's insensitivity toward his own family, it is unsurprising that he shows even less concern for his father's (or his employees') radicalism. Uncle Morty refers to his father as "Boob McNutt," telling him “This is Uncle Sam's country. Put it in your pipe and smoke it" (Odets 73). The unappealing portrayal of Uncle Morty — with Odets' insistence that all characters use the "Uncle" in his name, clearly referencing "Uncle Sam"—-becomes inextricably tied with American capitalism. And Odets' portrayal of capitalism is anything but sympathetic: "Marx! Some say Marx is the new God today. Maybe I'm wrong. Ha ha ha...Personally I 
counted my ten million last night...I'm sixteen cents short. So tomorrow I'll go to Union Square and yell no equality in the country!" (Odets 92).

In Raisin, it is Karl Lindner, a representative from the new neighborhood into which the Youngers plan to move, who serves as Uncle Morty's equivalent. Lindner is prepared to make the Youngers a "very generous offer" not to occupy their new home (Hansberry, $A$ Raisin 118). For Lindner and the people he represents, the community they have built does not involve other races as "Negro families" belong "in their own communities" (Hansberry, $A$ Raisin 118). Lindner offers money as a replacement for pride and choice, much in the same way that Uncle Morty uses money in place of humanity or compassion. Yet Lindner is not the clear embodiment of negativity found in Uncle Morty. Hansberry makes him surprisingly human - he is clearly uncomfortable, tries to be accommodating, and is a "gentle man" who is "thoughtful and somewhat labored in his manner" (Hansberry, A Raisin 115). Even as an embodiment of capitalism and racism, Lindner has positive attributes or, at least, is a softer representation than could be rightfully expected. For Lindner, too, is a product of a corruption that reaches beyond race, class, or status. As Hansberry writes, "Let us please be quite clear about one thing: I have treated Mr. Lindner as a human being merely because he is one" (Hansberry, To Be Young 117). All of Hansberry's characters-from Mama to Lindner-earn a compassion and a humanity not seen in Odets' Awake and Sing! Because the audience feels for them - and feels with them — their tragedy becomes palpable and strikes disturbingly close to home.

Theorist Georg Lukács once stated, paraphrasing Lenin, that "the masses can only be convinced of the truth of something when they have experienced it themselves" (106). Few Americans have experienced families as dysfunctional or overbearing as the Bergers. Fewer 
and fewer Americans remember the Great Depression. But many Americans have had the sense of somehow needing, wanting, or deserving more than is available. Such desires have made Lorraine Hansberry's A Raisin in the Sun more emotionally charged, successful, and ultimately critical of the American system than Clifford Odets'Awake and Sing! Yet, the existence of Odets' work makes Hansberry's all the more appreciable; the liminal moments where one can see Odets through Hansberry offer a glimpse at two worlds - both troubled, both flawed, and both in need of (r)evolution. Turner reminds us that the liminal occurs "when the past is momentarily negated, suspended, or abrogated, and the future has not yet begun, an instant of pure potentiality when everything, as it were, trembles in the balance" (Turner, From Ritual 44). For Hansberry, as well as Odets, "everything, as it were, trembles in the balance" in their plays. Viewing them side-by-side, with Hansberry's continued criticism of the historical moment and of Odets' play, raises the urgency and highlights the impetus of her work.

Adrienne Rich once wrote:

[...] if the imagination is to transcend and transform experience it has to question, to challenge, to conceive of alternatives, perhaps to the very life you are living at that moment. You have to be free to play around with the notion that day might be night, love might be hate; nothing can be too sacred for the imagination to turn into its opposite or to call experimentally by another name. For writing is re-naming. (Rich 23)

For Rich, and for Hansberry, and for all the artists in this study, "writing is re-naming." Writing is, fundamentally, an act of revision that continually brings the past forward, through the liminal, in order to insist upon on our failings and demand our reconsideration of our actions. For Hansberry, racism and economic disparity persist, but she offers the viewer and the reader a sliver of hope in the presence of a family that — unlike Odets' creation — persists 
despite overwhelming adversity. The Youngers, like these playwrights, continually keep an eye on the past while striving — sometimes against all odds—for a better future. 


\section{CONCLUSION: INTENTIONS AND IMPACTS}

\section{Artistic Intent and the Political}

While determining or questioning a writer's intent is always a dangerous game, it seems important to note that for all of the artists discussed herein, art is decidedly, inherently, and intentionally political. Imbued with a message, a viewpoint, and a drive, these artists' plays push towards creating more, whether more awareness, more anger, or more action. Williams never spoke openly of Tituba's Children, but his piece is nonetheless permeated by overt, didactic criticism. James Baldwin directly addressed the role of playwrights and writers, stating "Artists are the only people in a society who can tell that society the truth about itself" ("Words of a Native Son" 708). For Richard Wright, writing was a way to connect others in a common purpose (and fight): "I would hurl words into the darkness and wait for an echo, and if an echo sounded, no matter how faintly, I would send other words to tell, to march, to fight, to create sense of the hunger for life that gnaws in us all, to keep alive in our hearts a sense of the inexpressibly human" (Black Boy 384). Robert Lowell struggled with his message, finding himself both " a conventional liberal, concerned with causes, agitated about peace and justice and equality" while also "deeply conservative, wanting to get at the roots of things, wanting to slow down the whole modern process of mechanization and dehumanization" (qtd. in Schotter 73).

Lorraine Hansberry was clearer about her intentions in her play. Speaking about Raisin in a 1959 television interview with Mike Wallace, Hansberry asserted, "my play is actively a protest play, actively so. There is no contradiction between protest in art and good 
art" ("Television Portraits"). Baldwin supports this statement in his essay "Sweet Lorraine," noting, "[...] Lorraine made no bones about asserting that art has a purpose, and that its purpose was action: that it contained the 'energy which could change things'" (760). Change was something both Baldwin and Hansberry pursued.

Similarly, Arthur Miller, while asserting that a "play cannot be equated with a political philosophy" because "there is no political program — any more than there is a theory of tragedy—which can encompass the complexities of real life," nonetheless wrote overtly political plays and tragedies (Miller, "Death of a Salesman"). In discussing the relationship between the Salem Witch Trials and the HUAC/McCarthyism, Miller shows how a play can be both political and more than political, by arguing that his play was less about those particular historical/political events and more about "something very fundamental in the human animal: the fear of the unknown, and particularly the dread of social isolation" (“Again They Drink"). Pushing viewers and readers to understand themselves and their governments, Miller aspired for a play that would show "the country and the world $[\ldots]$ the continuity through time of human delusion" and its "only safeguard": "the law and the courageous few whose sacrifice illuminates delusion” (Miller, “Again They Drink”).

And perhaps that is the definition of political inherent to these plays: in imitating (but not mirroring) the past, these plays illuminate the failures and the cracks we so desperately wish to avoid. By layering past over present, the viewer (or reader) can begin to see the changes - indeed the possibility of difference, and thereby can begin to hope (or to push, or to fight) for such differences. Homi Bhabha reminds us that it is the critic (or in this case the artist-as-critic) who "must attempt to fully realize, and take responsibility for, the unspoken, unrepresented pasts that haunt the historical present" (18). Whatever their 
intentions, the playwrights represented herein are haunted by - and wish to ensure we are haunted by - a past that will not stay gone.

\section{The Theater as Medium}

The theater, while an odd choice for Baldwin the novelist or Williams and Lowell the poets, is an ideal venue for asserting a political message and a call to action. Put quite simply, "change in the theatre might produce change in the social world as well" (Potolsky 85). Augusto Boal offers a similar view on the stage, stating theater can "present always a vision of the world in transformation and therefore is inevitably political insofar as it shows the means of carrying out that transformation or of delaying it" (xiii). In their study of postcolonial theater, Brian Crow and Chris Banfield support the theater-as-agent-of-change model, arguing that it is the position of the spectator vis-à-vis the stage that creates theater's possibility of change. For them, “...theatre can overcome even the most grotesque inadequacies to 'hit' us with the truths it speaks" (108). The content matter, the presentation, and the potential energizing disturbance for the audience make the theater the ideal locus for art that seeks change.

While books appeal to our imaginations, plays mix this substantive "reality" with "quasi-religious ritual, illusionistic make-believe" that invites the spectator to fill in the blanks, engage their critical thinking skills, and participate in the spectacle (Brandt xiv). The theater thus becomes classroom, spectacle, and church - the engaging locus of education, entertainment, and ritual. Indeed, for Victor Turner, theater often takes the place of the sacred and the procedural, giving an outlet to frustration and dissent. The only difference, for Turner, between ritual and theater, rests in the assertion that "Ritual, unlike theatre, does not 
distinguish between audience and performers" (From Ritual 112). Nevertheless, theater, for Turner, plays an essential role:

Human beings learn through experience, though all too often they repress painful experience, and perhaps the deepest experience is through drama; not through social drama, or stage drama (or its equivalent) alone, but in the circulatory or oscillatory process of their mutual and incessant modification. (original emphasis; Turner, From Ritual 108)

The theater, with its back-and-forth movement between social drama and staged drama, has the capacity to keep experiences alive, and to keep the wound(s) we desperately wish to hide from healing. It is no surprise that dictators from Stalin to Hitler have silenced or exiled their playwrights, for it is drama that has the capacity to reach, and mobilize, an audience.

The impact we feel in the theater is not an impact we feel alone; we do not sit by ourselves in the theater. Instead, we are forced to react (or not react) amidst a crowd. Philip Auslander acknowledges the "putative ability [of performance] to create community (if not communion) among its participants, including performers and spectators" (4). Indeed, that collective consciousness is part of the strength of the theater, and a likely driving factor for these artists' selection of medium. The mimetic affects each of us differently, and we affect (or as Plato, Tolstoy, and Artaud may argue, infect ${ }^{73}$ ) those around us. We can be

\footnotetext{
${ }^{73}$ Desmond Lee, in his translation of The Republic, notes the connection between Plato's The Republic and Tolstoy's What is Art? Indeed, Plato spoke of poetry (and the mimetic arts) as one may describe a disease: "Our theme shall be that such poetry has no serious value or claim to truth, and we shall warn its hearers to fear its effects on the constitution of their inner selves" (Plato 352). Tolstoy often spoke of art as being able to "infect" others, much like a disease, but his view was more positive than Plato's. While he repeatedly uses the verb "to infect" to describe the function of art, discussing in particular the transfer of emotions from artist to audience ("The feelings with which the artist infects others may be most various, - very strong or very weak, very important or very insignificant..."; "If only the spectators or auditors are infected by the feelings which the author has felt, it is art; etc. ) $(42 ; 43)$, Tolstoy also sees such "infection" as decidedly human: "And if men lacked this other capacity of being infected by art, people might be almost more savage still, and, above all, more separated from, and more hostile to, one another" (44). Similarly, Antonin Artaud
} 
uncomfortable as we read about the executions during the Salem Witch Trials; we can feel remorse for Richard Henry (and subsequently Emmett Till) when he is gunned down on the page. But when we are surrounded by others experiencing similar emotions and we cannot process the information without ourselves being watched, the theater forces, if not actual action, at least a more immediate form of reckoning.

The stage, with its fourth wall, becomes a form of the Panopticon. ${ }^{74}$ When we are audience members, we know there is someone on stage, yet we do not know if we are being observed by the very people we watch. Additional audience members-who may watch the stage or may watch us - double the effect. This is in no way to suggest that the theater or the stage is a prison. But the combination of watching and potentially being watched does differentiate the theater from other forms of artistic expression and, as such, generates the possibility of unique power on and for the stage.

\section{Impacts}

For all the possibility inherent to the theater, none of the plays discussed here directly brought forth a protest, a riot, or a visible societal change. Instead, as part of the redressive means in Turner's concept of social drama, these works strived to move their (American)

references theater-as-plague in The Theater and Its Double: "If the essential theater is like the plague, it is not because it is contagious, but because like the plague it is the revelation, the bringing forth, the exteriorization of a depth of latent cruelty by means of which all the perverse possibilities of the mind, whether of an individual or a people, are localized" (30). Like Tolstoy, Artaud finds this plague, this darkness, necessary: "It releases conflicts, disengages powers, liberates possibilities, and if these possibilities and these powers are dark, it is the fault not of the plague nor the theater, but of life" (31).

${ }^{74}$ As described by Michel Foucault in Discipline and Punish, the Panopticon was created by philosopher and theorist Jeremy Bentham as a form of ultimate control. The placement of a tall, windowed tower in the center of the prison allows each cell to be seen by the guards in the tower while those in the tower cannot themselves be seen; the inmates thus feel watched at all times, whether or not a guard is actually present. 
communities towards resolution by moving them back into crisis. They imply that no resolution is possible without an adequate reckoning with our past, a reckoning that is sorely overdue. These playwrights insist, via revision, that we have seen this all before and that resolution — and even productive redress—still eludes us. Thus any move forward will require re-examination of our failings. Baldwin argues this point, stating, "History, as nearly no one seems to know, is not merely something to be read. And it does not refer merely, or even principally, to the past. On the contrary, the great force of history comes from the fact that we carry it within us, are unconsciously controlled by it in many ways, and history is literally present in all that we do" (original emphasis; "The White Man's Guilt" 722-723).

History, as these plays tell us again and again, is not in the past; it is part of our ongoing struggles. While Turner alleges that "no social drama can ever be finally concluded: the terms of its ending are often the conditions under which a new one will arise," his statement still suggests an ending, an at-least-temporary resolution, something these plays remind us we still lack (From Ritual 108). From continuing fears of anti-American thought and Communism, to the corruption/desire inherent in powerful political positions, to continued racial/gender/class/sexuality-based inequalities, to a simple lack of knowledge of our own American history, it is clear that these playwrights were correct in the mid-twentieth century, and they continue to be correct today.

And so, we look back because without doing so, we cannot look forward (or at the very least, we cannot move forward without, once again, getting mired in the past we so desperately want to ignore). Adrienne Rich applies this concept to the understanding of women's rights, but her words are equally applicable to these plays: "Re-vision—-the act of looking back, of seeing with fresh eyes, of entering an old text from a new critical 
direction - is for us more than a chapter in cultural history: It is an act of survival. Until we can understand the assumptions in which we are drenched we cannot know ourselves" (18). As these playwrights continually remind us, we do not sufficiently know ourselves—our history, our sins, or our solutions - and without that understanding, we cannot proceed. And so these plays, themselves redressive means, continually take us back to the breach and back to the moment of crisis. Crisis, Turner tells us, "is contagious" and it is public, and it "challenges the representatives of order to grapple with it" (The Anthropology 34). Crisis is itself a form of the liminal and it is anti-structural; it is all possibilities and no possibilities simultaneously. It is death and rebirth. It is a place from which we can rebuild. It leads us back to redressive means, the very moment we start from in drama, but this time, these plays seem to argue, we will come more prepared.

Thus, by calling America a modern Salem (Williams and Miller), or showing the injustice of killing a child via the injustice of killing a fictional adult (Baldwin), or decrying slavery/colonialism/racism via a familiar narrative (Melville, Wright and Lowell), or showing the power of an African American family over a failed, destructive, and racist community (Hansberry), these plays force viewers (and readers) back towards the crisis and into uncomfortable spaces. These spaces, these wounds, where past and present bleed both forwards and backwards (in the language of Anzaldúa and Bhabha), are the liminal, and they are the keys to our salvation:

Liminality, marginality, and structural inferiority are conditions in which are frequently generated myths, symbols, rituals, philosophical systems, and works of art. These cultural forms provide men with a set of templates, models, or paradigms which are, at one level, periodical reclassifications of reality (or, at least, of social experience) and man's relationship to society, nature, and culture. But they are more than (mere cognitive) classifications, since they incite men to action as well as thought. (Turner, From Ritual 52) 
Within the liminal, in the margins, via art (especially drama), we can begin to process and redefine the past in an attempt to recreate our present and reconsider our future.

By placing present over past, these plays revise historical and literary precedents, and that revision is itself a liminal and radical act. What may at first appear to be a simple act of rewriting is, in fact, the calculated resisting of the primacy of the original and a complicated process of creating new meaning. Particularly difficult for those who have been marginalized, such resistance is a large step in reclaiming power.

\section{Agitation and Nationalism}

It bears noting that revision, for all its anti-structural designs, ultimately both protests and affirms structure. By revising earlier works and history, these plays simultaneously reinforce the social structures (works, histories, hierarchies) from which they come and demand changes to those very structures. As Jesse Schotter reminds us, the process of adaptation, as similar to revision, "both preserves and radically transforms the material being adapted. While an adaptation potentially brings texts from the past into the present or exhibits them to a new audience through a change in medium, an adaptation also effects a partial destruction - albeit a creative destruction — of the source" (61). Thus the process of basing texts on previous historical or literary texts "is inherently both conservative $[\ldots]$ and progressive" (Schotter 61). We cannot remember (or re-member) the past without bringing it forward once again; we cannot challenge a text or our history without reliving it.

It is at first difficult to understand how texts with the anger of Wright's Man, God or the defiance of Miller's The Crucible can be seen as both progressive and conservative. And yet, inherent to each of these plays is a reaffirmation of the idealized superstructure-in the form of American idealism—-from which they descend. James Baldwin, whose Richard 
Henry is defiant to the point of his own destruction, railing against the society that sees him as little more than "a kind of walking phallic symbol" allowed to continually pay for the “sexual insecurity of others," ("The Black Boy” 270) nonetheless asserts, "I love America more than any other country in the world, and, exactly for this reason, I insist on the right to criticize her perpetually" (“Autobiographical Notes” 9). His work, like the work of the other playwrights discussed herein, attempts "to force the country to honor its own ideals" (Baldwin, "East River" 181). Despite the radicalism, what these plays share is an inherently conservative call: a return to the ideals that have not yet been realized.

Sacvan Bercovitch writes of this idealized space that the United States has come to occupy in the literary imagination. He notes that "the internalized, ideal America that inspired Emerson and his heirs; 'the only true America,' as Thoreau called it" has been a consistent source from "which the country's major authors have recurrently drawn upon (or withdrawn into) as an alternative to the dominant American Way" (The Rites 87). Bercovtich describes this space further: “'Not America,' was the way W.E.B. Du Bois put it, 'but what America might be - the Real America'" (The Rites 87). Bercovitch also evokes Langston Hughes, rightfully so, calling forth Hughes' poem, "Let America Be American Again," that so clearly describes America not as what it is, but as what it should be: "O, let American be American again — / The land that never has been yet—/ And yet must be — the land where every man is free" (original emphasis; Hughes, "Let America" 191). Like Hughes, these playwrights seek a kind of revolution. This is a revolution in multiple senses. It seeks to revolutionize America, but that demand also plays on the alternative meaning of revolution, the concept of turning or coming back around, like the planets around the sun. Thus this is a revolution of return, of sorts - a return to an ideal that has been vocalized but has yet to be 
realized. Baldwin offers us a more poetic understanding of this concept: "Societies never know it, but the war of an artist with his society is a lover's war, and he does, at his best, what lovers do, which is to reveal the beloved to himself, and with that revelation, make freedom real" ("The Creative Process," 672).

This subversion-as-conservatism is foregrounded by Bercovitch when he discusses its necessity to American Studies and American literature:

The principles of oppositionalism, so understood, center on an essentialist conflict between an always oppressive society and an always liberating literature - a sacred-secular library of America set against the ideologies in America of racism, imperialism, capitalism, and patriarchy. [....] My reading of the classic American authors convinced me that they were imaginatively nourished by the culture, even when they were politically opposed to it. (The Rites 16)

The system that so clearly requires change is also the system that feeds its artists as the push and pull between conservatism and progressiveness continues. Perhaps unique to American culture and society, however, is its ability "to compartmentalize dissent so as to absorb it, incrementally, unus inter pares, into a dominant liberal discourse" (Bercovitch, The Rites 21). These plays ask for change; the system absorbs that request (in the form of the question, not in the form of actual change) as a healthy expression of a functioning society. Yet in absorbing the request, the society also represses the demand and forestalls actual change; it is at once an act of acknowledgment and an act of containment. Without seeking to radically alter the superstructure, however, these plays cannot escape this cycle. What some have tried to posit as anti-American, then, is in reality the opposite. There is perhaps nothing more American than these plays' requests for a fulfillment of the ideals so often held up as the beacon of American exceptionalism. 


\section{Relevance to Literary Theory and Movements}

These plays' belief in a grand narrative_-one of (possible or theoretical) American idealism and exceptionalism — suggests that these works fall decidedly into modernism. The "layering of past and present events to suggest the simultaneity of historical event" that rendered characters and spaces as mythic or near-mythic, possessing " a universal as well as individual being" present in these texts supports the placement of these plays in the modernist camp (Lehan 16). From John's representation of a failed Christ in Man, God (leaving Babu an uninformed Pontius Pilate) to the eternally tortured truth-and-justiceseeking John Proctor in The Crucible, to the quintessential mother figure in Raisin, many of these plays' characters transcend (or rapidly approach) the boundary between the universal and the individual.

These plays also insist repeatedly that "reality was a matter of the way it was perceived" (Lehan 21). A belief in perspectivism dominates these works; it is how they choose — and are able — to revise the historical and the literary. These texts see themselves in a linear historical timeline and recognize T.S. Eliot's claim that "No poet, no artist of any art, has his complete meaning alone" ("Tradition" 1093). Inherent to Eliot's argument is the belief "that the past should be altered by the present as much as the present is directed by the past” (“Tradition” 1093). Indeed, speaking of James Joyce's Ulysses and its use of myth, Eliot charges future artists to use "a continuous parallel between contemporaneity and antiquity" in their works ("Ulysses, Order and Myth"):

They will not be imitators, any more than the scientist who uses the discoveries of an Einstein in pursuing his own, independent, further investigations. It is simply a way of controlling, of ordering, of giving a shape and a significance to the immense panorama of futility and anarchy which is contemporary history. ("Ulysses, Order and Myth") 
As Eliot tells us, modernists see the past and reality via their particular situation and personal history, and modern artists must recognize the influence of that past, that history, and that reality. To do so is to offer order to an unordered time.

Yet, given the time frame of the majority of these texts — ranging from 1935 to 1964 (excepting Melville) — they can be seen as rapidly approaching or reasonably falling within the time frames associated with post-modernism. ${ }^{75}$ These plays' concerns with language games, of hiding and revealing the past in present, is a type of "contract, explicit or not, between players," in this case, the viewer/reader and the playwright (Lyotard 10). Linda Hutcheon would likely place these texts firmly in postmodernism given their relationship to historiographic metafiction, a term she gives to a novel when "its theoretical self-awareness of history and fiction as human constructs (historiographic metafiction) is made the grounds for its rethinking and reworking of the forms and contents of the past" ${ }^{\text {"76 }}$ (original emphasis; A Poetics 5). Although Hutcheon is primarily concerned with novels, her definition could easily apply to the works discussed in this study.

Victor Turner suggests another reason for calling these texts postmodern:

Modernity means the exaltation of the indicative mood--but in [...] the 'postmodern turn,' we may be seeing a re-turn to subjunctivity and a rediscovery of cultural transformative modes, particularly in some forms of theatre. Dismembering may be a prelude to re-membering. Re-membering is not merely the restoration of some past intact, but setting it in living relationship to the present. (From Ritual 86)

\footnotetext{
${ }^{75}$ Modernism and post-modernism are difficult to define in terms of distinct starting and ending dates. Although many place post-modernism around World War II, some critics place it earlier or later, and certainly critics have placed "foundational" post-modern texts in the time frame between the wars, a time traditionally assigned to modernism.

${ }^{76}$ Of course, such a concept sounds, in many ways, remarkably like an enhanced definition of perspectivism, and thus the bleed between postmodernism and modernism continues.
} 
These plays deal in both the indicative (how it is) and the subjunctive (how it should be), placing them, by Turner's estimation, amidst the postmodern texts. For these reasons, along with the beginnings of disrupted/disorienting narrative structures (the circular narrative in Blues for Mister Charlie, for example), as well as an interest in the parodic, it is clear that these plays are located somewhere in the interstitial space between modernism and postmodernism, simultaneously modernist and proto-post-modernist. Once again, these texts populate the margins, the liminal, forcing readers and viewers to face them as original texts rather than products of their histories, their genres, or their moments.

\section{Moving Forward}

These plays are certainly not the only dramas (or texts) in American literature that rely on revision as a means of generating the new and the critical. But they do represent a compressed time in American history rife with political disruptions, cultural upheavals, identity politics, and a search for lost (or never present) ideals and idealism. Building off the social dramas that define them, and using the liminal, these texts offer overlays intending to show the past for its true weaknesses while also demonstrating the strength of those who have had to persevere through not only the present conditions, but the entire weight of the past, a past that is continually leaking forward, over the threshold.

Contemporary writers have continued this trend of offering past and present simultaneously, including Jean Rhys' novel Wide Sargasso Sea, Toni Morrison's novel Beloved, and Maryse Condé's novel I, Tituba, Black Witch of Salem (yet another revision of the Salem Witch Trials). Suzan Lori-Parks has played with historical revision in her play Venus, and I would argue that her play Topdog/Underdog is reminiscent in many ways of Sam Shepard's True West. All of these works suggest that the issues that plagued the mid- 
twentieth century continue forward, including troubled relations across races and cultures, concerns over nationalism or nationalist policies, and our inability to learn from our own historical mistakes and missteps.

But still, the artist, and the art, continues. James Baldwin said it best: "Yet one must also recognize that morality is based on ideas and that all ideas are dangerous - dangerous because ideas can only lead to action and where the action leads no man can say" ("Stranger in the Village" 126). Perhaps that is the moment to leave us with and what is best about the art discussed within the project: the future is unknown — the ideas are still dangerous. In a society clamoring to be called post-racial and post-patriarchal amidst circumstances that are anything but, perhaps we need these plays—and these "dangerous" ideas—-more than ever. Certainly we have not yet fully learned from our past, and, as these dramatists have told us repeatedly, that means we will have to face it once again. 


\section{WORKS CITED}

Abramson, Doris E. Negro Playwrights in the American Theatre 1925-1959. New York: Columbia University Press, 1967. Print.

Agamben, Giorgio. The Coming Community. Trans. Michael Hardt. Minneapolis: University of Minnesota Press, 1993. Print.

Allen, James. Without Sanctuary: Lynching Photography in America. Santa Fe: Twin Palms Publishers, 2004. Print.

Allen, Walter R. and Reynolds Farley. "The Shifting Social and Economic Tides of Black America, 1950-1980." Annual Review of Sociology 12 (1986): 277306. Web. 10 Oct. 2006.

ANTA Theatre. Blues for Mister Charlie. Playbill: the Magazine for Theatregoers 1.8 (August 1964): 17-30. Print.

Anzaldúa, Gloria. Borderlands: La Frontera. $2^{\text {nd }}$ ed. San Francisco: Aunt Lute Books, 1999. Print.

Apel, Dora and Shawn Michelle Smith. Lynching Photographs. Berkeley: University of California Press, 2007. Print.

Artaud, Antonin. The Theater and Its Double. Trans. Mary Caroline Richards. New York: Grove Press, Inc.: 1958. Print.

Ashley, Kathleen M. Introduction. Victor Turner and the Construction of Cultural Criticism: Between Literature and Anthropology. Ed. Kathleen M. Ashley. Bloomington, Indiana: Indiana University Press, 1990. ix-xxii. Print.

Atkinson, Brooks. "Fresh Talent: Clifford Odets Revealed as the Most Promising New American Dramatist.” New York Times. 10 Mar. 1935: X1. ProQuest. Web. 15 Oct. 2006.

Auslander, Philip. Liveness: Performance in a Mediatized Culture. New York: Routledge, 1999. Print.

"Awake and Sing!" BroadwayWorld.com. Wisdom Digital Media. n.d. Web. 25 Aug. 2013.

Baldwin, James. "Autobiographical Notes.” James Baldwin: Collected Essays. New York: The Library of America, 1998. 5-9. Print.

---. "The Black Boy Looks at the White Boy." 1954. James Baldwin: Collected Essays. New York: The Library of America, 1998. 269-285. Print. 
---. Blues for Mister Charlie. New York: Vintage Books, 1964. Print.

---. Conversations with James Baldwin. Ed. Fred L. Standley and Louis H. Pratt. Jackson: University Press of Mississippi, 1989. Print.

--- "The Creative Process." 1962. James Baldwin: Collected Essays. New York: The Library of America, 1998. 669-672. Print.

--- "East River, Downtown: Postscript to a Letter form Harlem." 1954. James Baldwin: Collected Essays. New York: The Library of America, 1998. 180-186. Print.

---. The Fire Next Time. 1963. James Baldwin: Collected Essays. New York: The Library of America, 1998. 288-347. Print.

---. “Negroes Are Anti-Semitic Because They're Anti-White." 1967. James Baldwin: Collected Essays. New York: The Library of America, 1998. 739-748. Print.

---. No Name in the Street. 1972. James Baldwin: Collected Essays. New York: The Library of America, 1998. 349-475. Print.

---. "Notes for Blues.” Blues for Mister Charlie. New York: Vintage Brooks, 1964. Print.

---. Notes of a Native Son. 1949. James Baldwin: Collected Essays. New York: The Library of America, 1998. 1-129. Print.

---. "Stranger in the Village." 1949. James Baldwin: Collected Essays. New York: The Library of America, 1998. 117-129. Print.

---. "Sweet Lorraine." 1969. James Baldwin: Collected Essays. New York: The Library of America, 1998. 757-761. Print.

---. “The White Man's Guilt.” 1965. James Baldwin: Collected Essays. New York: The Library of America, 1998. 722-727. Print.

--- "Words of a Native Son." 1964. James Baldwin: Collected Essays. New York: The Library of America, 1998. 707-713. Print.

---. "You cannot negotiate with your oppressor." 25 Sep. 1963. BlaCast Entertainment, 2002. CD.

Baraka, Amiri. "A Critical Reevaluation: A Raisin in the Sun's Enduring Passion." A Raisin in the Sun and The Sign in Sidney Brustein's Window. Lorraine Hansberry. New York: Random House, 1965: 9-20. Print. 
Barnett, Louise K. and James L. Thorson. Leslie Marmon Silko: A Collection of Critical Essays. Albuquerque: University of New Mexico Press, 1999. Web. 5 Jul. 2013.

Bercovitch, Sacvan. The American Jeremiad. Madison: University of Wisconsin, 1978. Print.

---. The Puritan Origins of the American Self. New Haven: Yale University Press, 1975. Print.

---. The Rites of Assent: Transformations in the Symbolic Construction of America. New York: Routledge, 1993. Print.

Berson, Misha. “Can Awake and Sing! Still Sing?” American Theatre. (Mar 06): 54-57. Web. 21 Aug. 2013.

Bhabha, Homi. The Location of Culture. New York: Routledge, 1994. Print.

Bigsby, Christopher. Introduction. The Crucible. 1953. New York: Penguin Books, 2003. vii-xxv. Print

Bigsby, C.W.E. Confrontation and Commitment: A Study of Contemporary American Drama 1959-1966. Columbia: University of Missouri Press, 1969. Print.

Bloom, Harold. The Anatomy of Influence. New Haven, Connecticut: Yale University Press, 2011. Print.

---. The Anxiety of Influence. New York: Oxford University Press, 1997. Print.

“"Blues for Mister Charlie' Closes After 150 Performances.” New York Amsterdam News. [New York] 05 September 1964: 16. ProQuest. Web. 1 Apr. 2006.

Boal, Augusto. Theatre of the Oppressed. Trans. Charles A. and Mari-Odilia Leal McBride. New York: Theatre Communications Group, 1985. Print.

Bose, Mandakranta. Movement and Mimesis: The Idea of Dance in the Sanskritic Tradition. New Delhi, DK Print World, 2007. Web. 29 Dec. 2012.

Brandt, George W. Introduction. Modern Theories of Drama: A Selection of Writings on Drama and Theatre, 1840-1990. Ed. George W. Brandt. Oxford: Clarendon Press, 1998. xiii-xxii. Print.

Bradley, David. Foreword. Eight Men. By Richard Wright. New York: Thunder's Mouth Press, 1987. ix-Xxv. Print.

Breslaw, Elaine G. "Tituba's Confession: the Multicultural Dimension of the 1692 
Salem Witch-Hunt.” Ethnohistory 44.3 (Summer 1997): 535-556. JSTOR. Web. 5 Jan. 2013.

Brignano, Russell Carl. Richard Wright: An Introduction to the Man and His Works. Pittsburgh: University of Pittsburgh Press, 1970. Print.

Brown, Lloyd W. "Lorraine Hansberry as Ironist: A Reappraisal of A Raisin in the Sun." Journal of Black Studies 4.3 (March 1974): 237-247. Print.

Camus, Albert. The Plague. 1947. Trans. Stuart Gilbert. The Plague, The Fall, Exile and the Kingdom, and Selected Essays. New York: Alfred A. Knopf, 2004. Print.

Carter, Steven R. “Commitment amid Complexity: Lorraine Hansberry's Life in Action." MELUS 7.3 (Autumn 1980): 39-53. JSTOR. Web. 1 Oct. 2006.

Castillo, Debra. Redreaming America. New York: State University of New York Press, 2005. Print.

"The Censure Case of Joseph McCarthy of Wisconsin (1954)." United States Senate. n.p., n.d. Web. 2 Feb. 2013.

Charles, Elizabeth Rundle. Te Deum laudamus: Christian life in song, the song and the singers. Great Britain: Society for Promoting Christian Knowledge, 1897. Web. 7 Jul. 2013.

Clurman, Harold. The Fervent Years: The Group Theatre and the Thirties. 1975. New York: Da Capo Press, Inc., 1983. Print.

---. Introduction. Waiting for Lefty and Other Plays. By Clifford Odets. New York: Grove Press, 1993. ix-xiv. Print.

---. "The Theatre of the Thirties." The Tulane Drama Review 4.2 (Dec. 1959): 3-11. Web.

Cochran, Robert. "Babo's Name in 'Benito Cereno': An Unnecessary Controversy?" American Literature 48.2 (May, 1976): 217-219. JSTOR. Web. 18 Oct. 2005.

Craker, Wendel D. "Spectral Evidence, Non-Spectral Acts of Witchcraft, and Confession at Salem in 1692." The Historical Journal 40.2 (June 1997): 331-358. JSTOR. Web. 1 Oct. 2005.

Crow, Brian and Chris Banfield. An Introduction to Post-Colonial Theatre. Cambridge: Cambridge University Press, 1996. Print.

Davis, Nicholas K. "Go Tell It On the Stage: Blues for Mister Charlie as Dialectical 
Drama." The Journal of American Drama and Theatre 17.2 (Spring 2005): 30-42. Print.

Davis, Ossie. "The Significance of Lorraine Hansberry." Freedomways 5.3 (Summer 1965): 397-402. Print.

DeGuzmán, María. Spain's Long Shadow: The Black Legend, Off-Whiteness, and Anglo-American Empire. Minneapolis: University of Minnesota Press, 2005. Print.

Delano, Amasa. Narrative of Voyages and Travels in the Northern and Southern Hemispheres: Comprising Three Voyages Round the World; Together with a Voyage of Survey and Discovery, in the Pacific Island and Oriental Islands. $2^{\text {nd }}$ ed. Boston: E.G. House, 1818. Web. 1 Jul. 2013.

Doloughan, Fiona J. Contemporary Narrative: Textual Production, Multimodality and Mutiliteracies. New York: Continuum International Publishing Group, 2011. Print.

Driver, Tom F. "The Review That Was Too True to Be Published." Critical Essays on James Baldwin. Ed. Fred L. Standley and Nancy V. Burt. Boston: G.K. Hall \& Co., 1988. Print.

Eliot, T.S. "Tradition and the Individual Talent." 1919. The Norton Anthology of Theory and Criticism. Ed. Vincent B. Leitch. New York: W.W. Norton \& Company, 2001. 1092-1098. Print.

---. “Ulysses, Order, and Myth.” University of Virginia. Web. 15 Jun. 2013.

Emery, Allan Moore. "The Topicality of Depravity in 'Benito Cereno." American Literature 55 (1983): 316-331. JSTOR. Web. 17 Oct. 2005.

"Emmett Till's casket donated to Smithsonian." The History Blog. WordPress, 2013. Web. 20 Aug. 2013.

Espinoza, Leslie. G. "Latino/a Identity and Multi-Identity." The Latino/a Condition. Ed. Richard Delgado and Jean Stefanic. New York: New York University Press, 1998. Print.

Evers, Myrlie. For Us, the Living. New York: Doubleday, 1967. Web. 1 Sept. 2013.

“FBI releases Emmett Till autopsy.” USA Today 30 Mar. 2007. Web. 15 Jul. 2013.

Field, Douglas. "Looking for Jimmy Baldwin: Sex, Privacy, and Black Nationalist Fervor." Callaloo 27.2 (Spring 2004): 457-480. Web. 22 Jan. 2006.

Foucault, Michel. Discipline and Punish: the Birth of the Prison. 1975. Trans. Alan 
Sheridan. New York: Vintage Books, 1995. Print.

Fox, Margalit. "Willie Louis, Who Named the Killers of Emmett Till at Their Trial, Dies at 76.” The New York Times 24 Jul. 2013. Web. 25 Jul. 2013.

Freud, Sigmund. Totem and Taboo. Trans. James Strachey. London: Routledge \& Kegan Paul, 1950. Print.

"Future-Karate Chop (Remix) Lyrics." Rap Genius. Genius Media Group, 2013. Web. 20 Aug. 2013.

Genette, Gérard. Palimpsests: Literature in the Second Degree. Trans. Channa Newman and Claude Doubinsky. Lincoln, Nebraska: University of Nebraska Press, 1997. Print.

Girard, René. "Mimesis and Violence.” 1979. The Girard Reader. Ed. James G. Williams. New York: The Crossroad Publishing Company, 1996. 9-19. Print.

---. The Scapegoat. 1982. Trans. Yvonne Freccero. Baltimore: The Johns Hopkins Press, 1986. Print.

Goldberg, Shari. "Benito Cereno's Mute Testimony: On the Politics of Reading Melville's Silences." Arizona Quarterly: A Journal of American Literature, Culture, and Theory 65.2 (Summer 2009): 1-26. Project Muse. Web. 13 Jun. 2013.

Gray, Jonathan. Watching the Simpsons: Television, Parody, and Intertextuality. New York: Routledge, 2006. Web. 10 Jan. 2013.

Greenberg, Cheryl Lynn. Troubling the Waters: Black-Jewish Relations in the American Century. Princeton: Princeton University Press, 2006. Print.

Hansberry, Lorraine. Letter from the author. 19 Jan. 1959. Print.

---. Letter from the author. 4 April 1962. Print.

---. Letter from the author. n.d. Print.

---. “Mailbag: O’Casey-Hansberry.” New York Times. 28 Jun. 1959: X3. Print.

---. "Notes for an Article on the Trial of Adolf Eichman." n.d. Print.

---. A Raisin in the Sun. 1958. New York: Vintage Books, 1994. Print.

---. To Be Young, Gifted and Black. Ed. Robert Nemiroff. New York: Vintage Books, 1995. Print. 
---. "Willie Loman, Walter Younger, and He Who Must Live." The Village Voice. 12 Aug. 1959: 7. Print.

Hansen, Chadwick. "The Metamorphosis of Tituba, or Why American Intellectuals Can't Tell and Indian witch from a Negro." The New English Quarterly 47.1 (Mar. 1974): 3-12. JSTOR. Web. 13 Nov. 2005.

Harper, Jennifer. "Poll: Obama policy 'will move' U.S. 'toward socialism.” The Washington Times 17 Dec. 2012. Web. 18 Dec. 2012.

Harris, Trudier. The Scary Mason-Dixon Line: African American Writers and the South. Baton Rouge: Louisiana State University Press, 2009. Print.

Hattenhauer, Darryl. “Follow Your Leader': Knowing One's Place in 'Benito Cereno." Rocky Mountain Review of Language and Literature 45 (1991): 7-17. JSTOR. Web. 19 Sep. 2005.

Hellman, Lillian. Pentimento: A Book of Portraits. New York: New American Library, 1973. Print.

Herbert, George. "Master and Slave in Robert Lowell's 'Benito Cereno." REN 43.4 (Summer 1991): 292-302. Web. 20 May 2013.

Hernton, Calvin C. "A Fiery Baptism.” James Baldwin: A Collection of Critical Essays. Ed. Keneth Kinnamon. Englewood Cliffs, NJ: Prentice-Hall, Inc., 1974. Print.

Herr, Christopher. Clifford Odets and American Political Theatre. Westport: Praeger, 2003. Print.

Hofstadter, Richard. "The Paranoid Style in American Politics." The Paranoid Style in American Politics and Other Essays. Cambridge: Harvard University Press, 1952. Print.

Houck, Davis W. and Matthew A. Grindy. Emmett Till and the Mississippi Press. Jackson: University of Mississippi, 2008. Print.

"HUAC (House Un-American Activities Committee)." The History Channel website. n.p., 2013. Web. 5 Feb. 2013.

Hughes, Langston. "Let America Be America Again." The Collected Poems of Langston Hughes. Ed. Arnold Rampersad. New York: Vintage Classics, 1994. 189-191. Print.

---. "The Negro Artist and the Racial Mountain." The Norton Anthology of Theory and Criticism. Ed. Vincent B. Leitch. New York: W.W. Norton \& Company, 2001. 


\section{3-1317. Print.}

---. "Silhouette." The Collected Poems of Langston Hughes. Ed. Arnold Rampersad. New York: Vintage Classics, 1994. 305-306. Print.

Hutcheon, Linda. A Poetics of Postmodernism: History, Theory, Fiction. New York: Routledge, 1988. Print.

---. A Theory of Parody: The Teachings of Twentieth-Century Art Forms. Chicago: University of Illinois Press, 2000. Print.

Inman, Mary. In Woman's Defense. Los Angeles: The Committee to Organize the Advancement of Women, 1940. Print.

Jemie, Onwuchekwa. “Or Does it Explode?” Langston Hughes: Critical Perspectives Past and Present. Ed. Henry Louis Gates, Jr. and K.A. Appiah. New York: Amistad Press, Inc., 1993. 135-171. Print.

Johnson, Malcolm. "Puff Daddy a Drag on 'Raisin' Revival—New York Stage." The Hartford Courant. 27 April 2004: D1. NewsBank. Web. 5 Aug. 2013.

Knauf, David. “Notes on Mystery, Suspense, and Complicity: Lowell's Theatricalization of Melville's 'Benito Cereno." Educational Theatre Journal 27.1 (Mar. 1975): 40-55. JSTOR. Web. 20 Jun. 2013.

Krasner, Jonathan. "The Interwar Family and American Jewish Identity in Clifford Odets's 'Awake and Sing!'” Jewish Social Studies 13.1 (Autumn 2006): 2-30. ProQuest. Web. 10 Aug. 2013.

Kristeva, Julia. Powers of Horror: An Essay on Abjection. 1980. Trans. Leon S. Roudiez. New York: Columbia University Press, 1982. Print.

---. The Sense and Non-Sense of Revolt: The Powers and Limits of Psychoanalysis. 1996. Trans. Jeanine. Herman. New York: Columbia University Press, 2000. Print.

Larson, Jennifer. Understanding Suzan-Lori Parks. Columbia: University of South Carolina Press, 2012. Print.

Lehan, Richard. Literary Modernism and Beyond: the Extended Vision and the Realms of the Text. Baton Rouge: Louisiana State University Press, 2009. Print.

Leslie, Joshua and Sterling Stuckey. "The Death of Benito Cereno: A Reading of Herman Melville on Slavery: The Revolt on Board the Tryal." The Journal of Negro History 67.4 (Winter, 1982): 287-301. JSTOR. Web. 14 May 2013.

Lewis, Allan. American Plays and Playwrights of the Contemporary Theatre. 
New York: Crown Publishers, 1965. Print.

Liker, Jeffrey K. and Glen H. Elder, Jr. "Economic Hardship and Marital Relations in the 1930s." American Sociological Review 48.3 (Jun. 1983): 343-359. JSTOR. Web. 12 Oct. 2006.

Littlejohn, David. Black on White: A Critical Survey of Writing by American Negroes. New York: Grossman Publishers, 1966. Print.

Lowell, Robert. Benito Cereno. The Old Glory. By Robert Lowell. New York: Farrar, Straus \& Giroux, 1964. Print.

Lukács, Georg. Realism in Our Time: Literature and the Class Struggle. Trans. John and Necke Mander. New York: Harper \& Row, 1962. Print.

Lyotard, Jean-François. The Postmodern Condition: A Report on Knowledge. 1979. Trans. Geoff Bennington and Brian Massumi. Minneapolis: University of Minnesota Press, 1984. Print.

Malburne, Meredith M. "No Blues for Mister Henry: Locating Richard's Revolution." Reading Contemporary African American Drama: Fragments of History, Fragments of Self. Ed. Trudier Harris. New York: Peter Lang, 2007. Print.

Malburne-Wade, Meredith M. Questionnaire. Chambersburg/Gettysburg: 2010-2012.

Malburne-Wade, Meredith M. Questionnaire. Chapel Hill: 2011.

McBride, Dwight, Ed. James Baldwin Now. New York: NYU Press, 1999. Print.

"McCarthyism." Wikipedia. Wikipedia, The Free Encyclopedia, 2 Aug. 2013. Web. 5 Feb. 2013.

Melville, Herman. Benito Cereno. Billy Budd, Sailor and Other Stories. New York: Penguin Books, 1986. Print.

Millbank, Dana. "A filibuster fit for McCarthy." Washington Post Opinions. 26 Feb. 2013. Web. 27 Feb. 2013.

Miller, Arthur. "Again They Drink from the Cup of Suspicion." The New York Times On the Web 26 November 1989. Web. 1 Nov. 2005.

---. “Are you Now or Were you Ever?” The Guardian/The Observer (online)

17 June 2000. Web. 1 Nov. 2005.

---. The Crucible. 1953. New York: Penguin Books, 2003. Print. 
---. "Death of a Salesman." 1958. Playwrights on Playwriting: From Ibsen to Ionesco. 1960. Ed. Toby Cole. New York: Cooper Square Press, 2001. 261-276. Print.

---. Timebends; A Life. New York: Grove Press, 1987. Print.

Miller, D. Quentin, Ed. Re-Visiting James Baldwin: Things Not Seen. Philadelphia: Temple University Press, 2000. Print.

Miller, Jordan Y. "Lorraine Hansberry." The Black American Writer. Ed. C.W.E. Bigsby. Vol. II: Poetry and Drama. Baltimore, Penguin, 1971. Print.

Mitchell, Koritha. "James Baldwin, Performance Theorist, Sings the Blues for Mister Charlie." American Quarterly 64.1 (March 2012): 33-60. Project Muse. Web. 7 Jul. 2012.

Mitchell, Loften. Black Drama. New York: Hawthorn Books, 1967. Print.

Molette, Carlton W. "James Baldwin as Playwright." James Baldwin: A Critical Evaluation. Ed. Therman B. O'Daniel. Washington, DC: Howard University Press, 1977. Print.

Morrison, Toni. Preface. Playing in the Dark: Whiteness and the Literary Imagination. New York: Vintage Books, 1993. v-xiii. Print.

Nelson, Dana. The Word in Black and White. New York: Oxford University Press, 1992. Print.

Nelson, Emmanuel S. "James Baldwin's Vision of Otherness and Community." Critical Essays on James Baldwin. Ed. Fred L. Standley and Nancy V. Burt. Boston: G.K. Hall \& Co., 1988. Print.

Nemiroff, Robert. Introduction. A Raisin in the Sun. 1958. By Lorrain Hansberry. New York: Vintage Books, 1994. 5-14. Print.

Nietzsche, Friedrich. The Use and Abuse of History. 1873. New York: Cosimo Classics, 2005. Print.

Norma and Joe. Letter to the author. 18 Mar. 1959. Print.

Odets, Clifford. Awake and Sing! 1933. Waiting for Lefty and Other Plays. New York: Grove Press, 1993. Print.

“"The Old Glory' to Re-Open.” N.Y. Amsterdam News 16 Jan. 1965: 14. ProQuest. Web. 5 May 2013. 
Orr-Klopfer, M. Susan. The Emmett Till Book. Lexington: M.S. Orr-Klopfer, 2005. Print.

Palmer, Caroline. "Mutiny with a Mission." American Theatre 14.1 (Jan 97). MasterFILE Complete. Web. 5 May 2013.

Plato. The Republic. Trans. Desmond Lee. New York: Penguin Classics, 2007. Print.

"Play." The Oxford English Dictionary. 2013. Web. 10 Oct. 2012.

Potolsky, Matthew. Mimesis. New York: Routledge, 2006. Print.

Putzel, Max. "The Source and Symbols of Melville's 'Benito Cereno.' American Literature 34. 2 (May 1962): 191-206. JSTOR. Web. 13 Jun. 2013.

R. Brandon. (_Bran_don). "Django Djelloshots? Emmitt Tillapia? Malcolm Xtra Hot Wings. I can’t...\#paulasbestdishes.” 19 Jun. 2013. Tweet.

Rabinowitz, Paula. "Women and U.S. Literary Radicalism." Writing Red: An Anthology of American Women Writers, 1930-1940. Ed. Charlotte Nekola and Paula Rabinowitz. New York: The Feminist Press, 1987. 1-16. Print.

“Raisin.” BroadwayWorld.com. Wisdom Digital Media. n.d. Web. 25 Aug. 2013.

"A Raisin in the Sun." BroadwayWorld.com. Wisdom Digital Media. n.d. Web. 25 Aug. 2013.

Ralph, George. 'History and Prophecy in 'Benito Cereno.' Educational Theatre Journal 22.2 (May, 1970): 155-160. Print.

Raper, Arthur F. The Tragedy of Lynching. Chapel Hill: University of North Carolina Press, 1933. Print.

Raybin, David. "Aesthetics, Romance, and Turner." Victor Turner and the Construction of Cultural Criticism: Between Literature and Anthropology. Ed. Kathleen M. Ashley. Bloomington, Indiana: Indiana University Press, 1990. 21-41. Print.

Redding, Saunders. "Review of Eight Men." The Critical Response to Richard Wright. Ed. Robert J. Butler. Westport: Greenwood Press, 1995. Print.

Reimer, Andrew. "Translation, Imitation and Parody." Australian Journal of French Studies 47.1 (2010): 36-45. Print.

Reis, Elizabeth. "Confess or Deny? What's a 'Witch' to Do?" OAH Magazine of History 17.4 (Jul. 2003): 11-13. JSTOR. Web. 18 September 2013. 
Rich, Adrienne "When We Dead Awaken: Writing as Re-Vision." College English 34.1 (Oct. 1972): 18-30. Print.

Riley, Clayton. "On Black Theater.” The Black Aesthetic. Ed. Addison Gayle. Garden City: Doubleday, 1971. Print.

Robertson, Nan. "Dramatist Against Odds." New York Times. (8 Mar 1959): X3. ProQuest. Web. 1 Jan. 2012.

Robins, Natalie. Alien Ink: The FBI's War on Freedom of Expression. New Brunswick: Rutgers University Press, 1992. Print.

Rosenthal, Bernard. "Copying a Source Need Not be Plagiarism [letter]." New York Times 27 Dec. 1981 late ed.: A14. ProQuest. Web. 13 Jun. 2013.

Roth, Philip. "Blues for Mister Charlie." Modern Critical Views: James Baldwin. Ed. Harold Bloom. New York: Chelsea House Publishers, 1986. Print.

Sanders, Julie. Adaptation and Appropriation. New York: Routledge, 2006. Print.

Saunders, Frances Stonor. The Cultural Cold War: The CIA and the World of Arts and Letters. New York: The New Press, 1999. Print.

Schechner, Richard. Between Theater and Anthropology. Philadelphia: University of Pennsylvania Press, 1985. Print.

Schotter, Jesse. "Adaptation Liberal and Conservative: Benito Cereno and Robert Lowell's Literary and Racial Politics.” Genre XLII (Spring/Summer 2009): 61-82. Web. 20 May 2013.

Schultz, Elizabeth. "The Power of Blackness: Richard Wright Re-Writes Moby Dick." African American Review 33 (1999): 639-654. JSTOR. Web. 17 Oct. 2005.

Scofield, Martin P. The Cambridge Introduction to the American Short Story. Cambridge: Cambridge University Press, 2006. Web. 15 Jan. 2012.

Scudder, Harold H. “Melville's Benito Cereno and Captain Delano's Voyages.” PMLA 43.2 (Jun. 1928): 502-532. JSTOR. Web. 13 Jun. 2013.

Shuman, R. Baird. "[Awake and Sing!].” Critical Essays on Clifford Odets. Ed. Gabriel Miller. Boston: G.K. Hall \& Co., 1991. Print.

Simon, John. Uneasy Stages: A Chronicle of the New York Theater, 1963-1973. New York: Random House, 1975. Print.

Singh, Raman K. "Christian Heroes and Anti-Heroes in Richard Wright's Fiction." 
Negro American Literature Forum 6 (1972): 99-104+131. JSTOR. Web. 17 Oct. 2005.

Slocombe, Will. "Did Melville Misplace Santa Maria in Benito Cereno?"

MHRA Working Papers in Humanities 4 (2009): 25-33. Web. 12 Jun. 2013.

Starkey, Marion L. The Devil in Massachusetts: A Modern Enquiry into the Salem Witch Trials. 1949. Garden City: Dolphin Books, 1961. Print.

Sylvander, Carolyn Wedin. James Baldwin. New York: Frederick Ungar Publishing Company, 1980. Print.

“Television Portraits of Colorful People.” CBS. 8 May 1959. Television (transcript).

Terkel, Studs. "Make New Sounds.” American Theatre 1.7 (Nov. 1984): 5-8, 41. Print.

Tolstoy, Leo. What is Art? Trans. Aylmer Maude. New York: Funk \& Wagnalls Company, 1904. Web. 29 Nov. 2012.

Turner, Darwin T. "James Baldwin in the Dilemma of the Black Dramatist." James Baldwin: A Critical Evaluation. Ed. Therman B. O'Daniel. Washington, DC: Howard University Press, 1977. Print.

Turner, Victor. The Anthropology of Performance. New York: PAJ Publications, 1987. Print.

---. Foreword. The Ritual Process: Structure and Anti-Structure. 1969. Ithaca: Cornell University Press, 1977. v-viii. Print.

----. From Ritual to Theatre: The Human Seriousness of Play. New York: PAJ Publications, 1982. Print.

--. The Ritual Process: Structure and Anti-Structure. 1969. Ithaca: Cornell University Press, 1977. Print.

Turpin, Waters E. “A Note on Blues for Mister Charlie.” James Baldwin: A Critical Evaluation. Ed. Therman B. O'Daniel. Washington, DC: Howard University Press, 1977. Print.

Tynan, Kenneth. Curtains: Selections from the Drama Criticism and Related Writings. New York: Atheneum, 1961. Print.

The Untold Story of Emmett Louis Till. Till Freedom Come Productions, LLC. Web. 19 April 2006.

Upham, Charles. Salem Witchcraft; with an Account of Salem Village and a History 
of Opinions on Witchcraft and Kindred Subjects. 1867. 2 vols. Williamstown: Corner House Publishers, 1971. Print.

Vanderhaar, Margaret M. “A Re-Examination of 'Benito Cereno.”' American Literature 40 (May, 1968): 179-191. JSTOR. Web. 18 Oct. 2005.

van Gennep, Arnold. The Rites of Passage. Chicago, The University of Chicago Press, 1960. Print.

Warner, John. "Why James Baldwin Beat William F. Buckley in a Debate, 540-160." The Education of Oronte Churm. Inside Higher Ed. Web. 03 March 2013.

Washington, J. Charles. "A Raisin in the Sun Revisited." Black American Literature Forum 22.1 (Spring 1988): 109-124. JSTOR. Web. 10 Oct. 2006.

Weales, Gerald. "Clifford's Children: or It's a Wise Playwright Who Knows His Own Father." 1987. Critical Essays on Clifford Odets. Ed. Gabriel Miller. Boston: G.K. Hall \& Co., 1991. Print.

---. "Drama." Harvard Guide to Contemporary American Writing. Ed. Daniel Hoffman. Cambridge: Belknap Press, 1979. 396-438. Print.

---. "Thoughts on A Raisin in the Sun.” Commentary 27.6 (June 1959): 527-530. Print.

Whitfield, Stephen J. The Culture of the Cold War. Baltimore: The Johns Hopkins University Press, 1991. Print.

Wiegman, Robyn. American Anatomies: Theorizing Race and Gender. Durham: Duke University Press, 1995. Print.

Wiese, Andrew. Places of Their Own: African American Suburbanization in the Twentieth Century. Chicago: The University of Chicago Press, 2004. Print.

Williams, William Carlos. Tituba's Children. Many Loves and Other Plays: The Collected Plays of William Carlos Williams. Ed. William Carlos Williams. New York: New Directions, 1961. Print.

Wills, Gary. Introduction. Scoundrel Time. By Lillian Hellman. New York: Bantam Books, 1976. 1-31. Print.

Winter, Lind. "'Benito Cereno' needs to smooth the edges." Chicago Tribune 21 Nov. 1975: B2. ProQuest. Web. 5 May 2013.

Wright, Richard. Black Boy. 1945. New York: Harper Perennial, 2006. Print. 
---. Black Power. 1954. Black Power: Three Books from Exile: Black Power; The Color Curtain; and White Man, Listen! New York: Harper Perennial, 2008. Print.

---. Man, God Ain't Like That.... Eight Men. 1961. Ed. Richard Wright. New York: Harper Perennial, 2008. Print.

---. 12 Million Black Voices. 1941. New York: Basic Books, 2008. Print.

---. White Man, Listen! 1957. Black Power: Three Books from Exile: Black Power; The Color Curtain; and White Man, Listen! New York: Harper Perennial, 2008. Print.

Yankowitz, Susan. "Lowell's Benito Cereno: An Investigation of American Innocence." Theater Summer 2.2 (1969): 81-90. Web. 5 May 2013. 